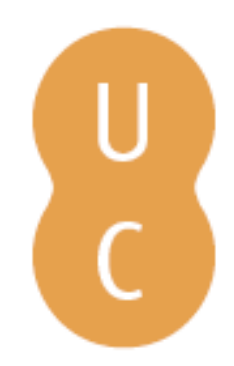

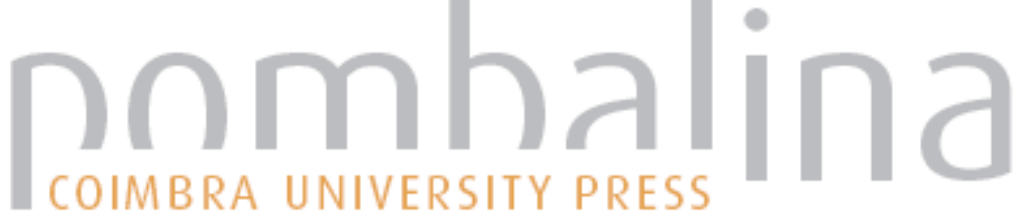

\section{Luciano IX}

Autor(es): $\quad$ Samósata, Luciano de; Magueijo, Custódio, trad.

Publicado por: Imprensa da Universidade de Coimbra

URL

persistente:

URI:http://hdl.handle.net/10316.2/29949

DOI:

DOI:http://dx.doi.org/10.14195/978-989-26-0796-2

Accessed : $\quad$ 26-Apr-2023 13:46:45

A navegação consulta e descarregamento dos títulos inseridos nas Bibliotecas Digitais UC Digitalis, UC Pombalina e UC Impactum, pressupõem a aceitação plena e sem reservas dos Termos e Condições de Uso destas Bibliotecas Digitais, disponíveis em https://digitalis.uc.pt/pt-pt/termos.

Conforme exposto nos referidos Termos e Condições de Uso, o descarregamento de títulos de acesso restrito requer uma licença válida de autorização devendo o utilizador aceder ao(s) documento(s) a partir de um endereço de IP da instituição detentora da supramencionada licença.

Ao utilizador é apenas permitido o descarregamento para uso pessoal, pelo que o emprego do(s) título(s) descarregado(s) para outro fim, designadamente comercial, carece de autorização do respetivo autor ou editor da obra.

Na medida em que todas as obras da UC Digitalis se encontram protegidas pelo Código do Direito de Autor e Direitos Conexos e demais legislação aplicável, toda a cópia, parcial ou total, deste documento, nos casos em que é legalmente admitida, deverá conter ou fazer-se acompanhar por este aviso. 


\section{LuCiano de Samósata}

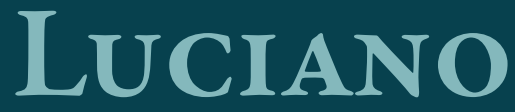

[IX]

TRADUÇÃo DO GREGO, INTRODUÇÃO E NOTAS Custódio Magueijo 
(Página deixada propositadamente em branco) 


\section{Luciano de Samósata}

\section{Luciano}

\section{[IX]}

Tradução do grego, introdução e notas de Custódio Magueijo

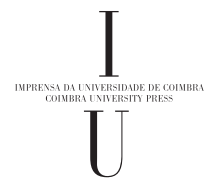




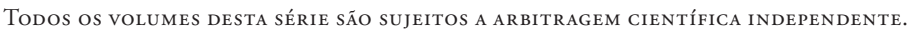

Título • Luciano IX

Autor • Luciano de Samósata

Série Autores Gregos e Latinos

Coordenador Científico do plano de ediçấo: Maria do Céu Fialho

Comissão Editorial

José Ribeiro Ferreira

Francisco de Oliveira

Maria de Fátima Silva

Nair Castro Soares

Director Técnico: Delfim Leão

\section{Obra REALIZADa No ÂMbito DaS actividades Da UI\&D Centro de Estudos Clássicos e Humanísticos}

\section{EdiçÃo}

Imprensa da Universidade de Coimbra

URL: http://www.uc.pt/imprensa_uc

E-mail: imprensauc@ci.uc.pt

Vendas online:

http://ivrariadaimprensa.uc.pt

CoORdenaÇÁo EDITORIAL

Imprensa da Universidade de Coimbra

\section{CONCEPÇÃo GRÁFICA}

Imprensa da Universidade de Coimbra

INFOGRAFIA

Mickael Silva

\author{
Impressão e Acabamento \\ WWW.ARTIPOL.NET \\ ISBN \\ 978-989-26-0795-5 \\ ISBN Digital \\ 978-989-26-0796-2 \\ DOI
}

http://dx.doi.org/

10.14195/978-989-26-0796-2

Depósito Legal

$353356 / 12$

Ia EdIÇÃo: IUC・2013

(C) Dezembro 2013.

IMPRENSA DA UNIVERSIDADE DE COIMBRA

Classica Digitalia Vniversitatis Conimbrigensis (http://classicadigitalia.uc.pt)

Centro de Estudos Clássicos e Humanísticos da Universidade de Coimbra

Reservados todos os direitos. Nos termos legais fica expressamente proibida a reproduçáo total ou parcial por qualquer meio, em papel ou em ediçáo electrónica, sem autorizaçáo expressa dos titulares dos direitos. É desde já excepcionada a utilizaçáo em circuitos académicos fechados para apoio a leccionaçáo ou extensáo cultural por via de e-learning. 


\section{ÍNDICE}

INTRODUÇÃO GERAL ................................................................

HERÓDOTO OU AÉCION ....................................................... Is

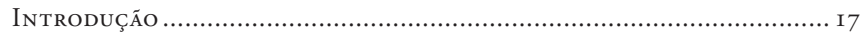

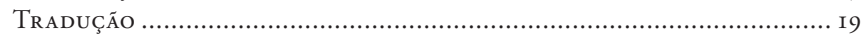

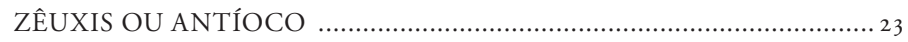

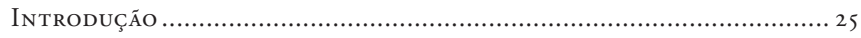

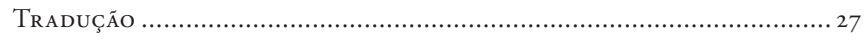

JUSTIFICAÇĀO DE UMA FALTA DITA AO SAUDAR …....................... 35

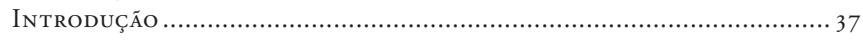

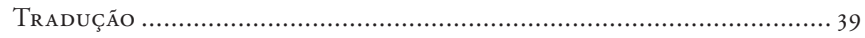

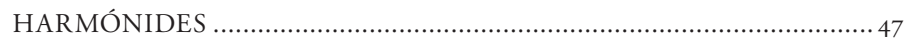

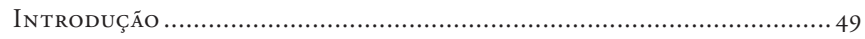

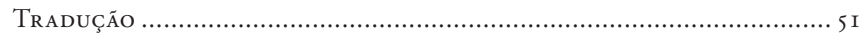

DISCUSSÃO COM HERÍODO....................................................... 57

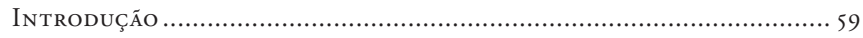

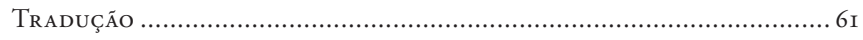

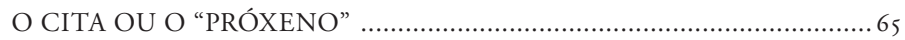

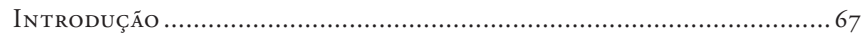

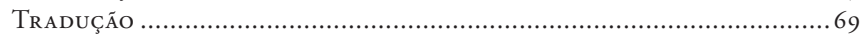

"ÉS UM PROMETEU... NAS PALAVRAS" ................................................ 77

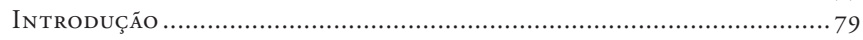

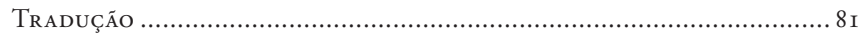

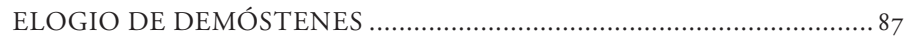

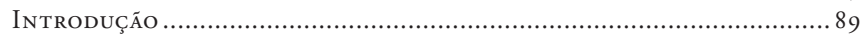

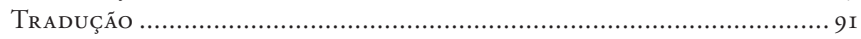

ALCÍONE OU METAMOSFOSES ................................................ I I 7

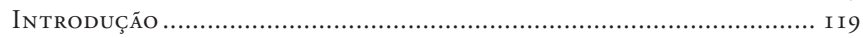

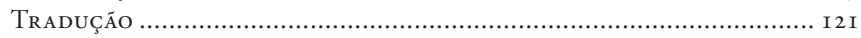

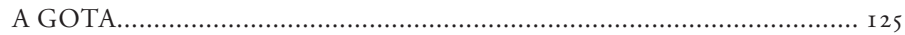

INT RODUÇÃO ............................................................................. I 27

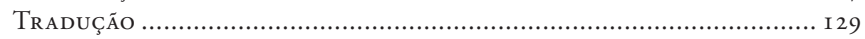

OCÍPODE [O HOMEM DOS PÉS LIGEIROS] ............................... I 43

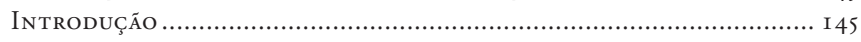

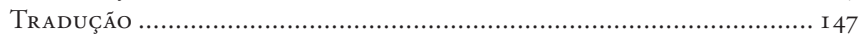


O PATRIOTA OU O DISCÍPULO ................................................ I 57

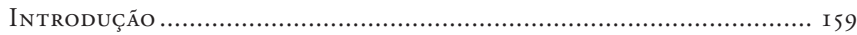

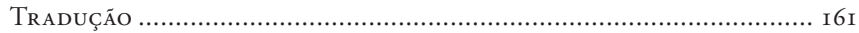

NERO [OU A ABERTURA DO ISTMO] .................................... I79

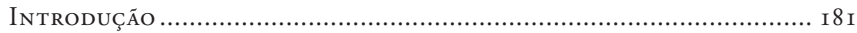

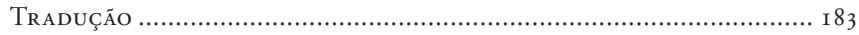

O PSEUDO-SOFISTA OU O SOLECISTA ........................................ I 89

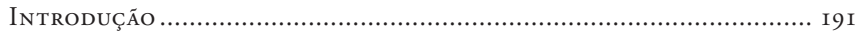

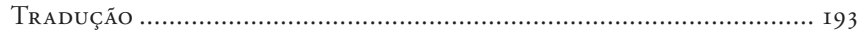

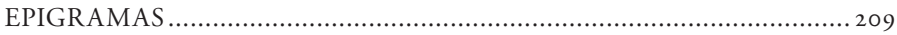

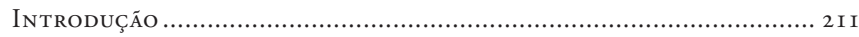

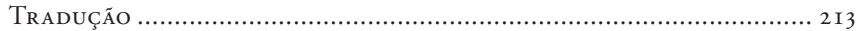




\section{LUCIANO}

[IX]

\section{Heródoto ou Aécion}

ZêUXIs ou Antíoco

Justificação de uma Falta Dita ao Saudar

HARMÓNIDES

Discussáo com Hesíodo

O Cita ou O "Próxeno"

“És um Prometeu... nas Palavras"

Elogio de Demóstenes

Alcíone ou As Metamorfoses

A Gota

Ocípode [O Homem dos Pés Ligeiros]

O Patriota ou O Discípulo

Nero [ou A Abertura do Istmo]

O Pseudo-sofista ou O Solecista

EpIGRAMAS 
Ficha Técnica:

Autor: Luciano de Samósata

Título: LUCIANO [IX]:

- Heródoto ou Aécion

- Zêuxis ou Antíoco

- Justificação de uma Falta Dita ao Saudar

- Harmónides

- Discussão com Hesiodo

- O Cita ou O "Próxeno"

- "És um Prometeu... nas Palavras"

- Elogio de Demóstenes

- Alcione ou As Metamorfoses

- A Gota

- Ocipode [O Homem dos Pés Ligeiros]

- O Patriota ou O Discípulo

- Nero [ou A Abertura do Istmo]

- O Pseudo-sofista ou O Solecista

- Epigramas

Tradução, introdução e notas: Custódio Magueijo 


\section{INTRODUÇÁO GERAL ${ }^{1}$}

Luciano nasceu em Samósata, capital do antigo reino de Comagena, situado a norte da Síria, na margem direita do Eufrates. Os primeiros imperadores romanos conservaram-lhe um certo grau de independência, mas acaba por ser incluído entre as províncias do Império Romano.

Quanto a datas de nascimento e morte, aceitemos 125-190 d.C. Seguramente, a vida literária de Luciano desenvolve-se na segunda metade do séc. II d.C., por um período de quarenta anos, durante o qual escreveu cerca de oitenta obras.

No tocante a dados biográficos, temos de contentar-nos com as informações contidas no conjunto dos seus escritos. Pelo menos têm a vantagem de serem de primeira mão. E se a nossa curiosidade mais "superficial» gostaria de saber muitas outras coisas sobre a sua vida, a verdade é que o essencial do homem está nítida e magnificamente retratado na obra.

De entre as obras mais importantes do ponto de vista autobiográfico, salienta-se a intitulada $O$ Sonho (ou Vida de Luciano). Imediatamente se conclui tratar-se dum trabalho da meia-idade, que mais abaixo resumimos.

Após uma peregrinação de vários anos por terras da Grécia, da Itália e da Gália, onde conseguira assinalável êxito e não menos importante pecúlio, Luciano regressa (por volta de 162-163) à sua cidade natal, que o havia visto partir pobre $\mathrm{e}$ quase anónimo, e agora se orgulhava do prestígio que lhe era transmitido pelo próprio êxito dum filho seu. É então que Luciano, perante os seus concidadáos, traça uma retrospectiva autobiográfica, da qual mencionamos os passos mais salientes.

Chegado ao termo da escolaridade elementar, adolescente de quinze anos, o pai aconselha-se com familiares e amigos sobre o futuro do moço.

"A maioria opinou que a carreira das letras requeria muito esforço, longo tempo, razoável despesa e uma sorte brilhante. Ora, a nossa fortuna era limitada, pelo que, a breve trecho, precisaríamos de alguma ajuda.

${ }^{1}$ Esta «Introdução geral» é, na verdade, reproduzida de outras que escrevi a propósito de diversas obras de Luciano. Não se pode exigir que, para cada uma das cerca de oitenta, tivesse de inventar uma biografia formalmente diferente de Luciano. No entanto, a parte final, relativa a cada obra em particular, é redigida especialmente para esta edição. 
Se, pelo contrário, eu aprendesse um ofício, começaria imediatamente a retirar dai um salário minimo, que me permitiria, naquela idade, deixar de ser um encargo familiar, e até mesmo, algum tempo depois, dar satisfação a meu pai com o dinheiro que traria para casa." (\$ 1)

Restava escolher o ofício. Discutidas as várias opinióes, foi decidido entregar o rapaz aos cuidados dum tio materno, presente na reunião, e que era um excelente escultor. Além deste factor de ordem familiar, pesou ainda o facto de o moço, nos seus tempos livres, gostar de se entreter a modelar, em cera, bois, cavalos e figuras humanas, "tudo muito bem parecido, na opiniáo de meu pai». Por essa actividade "plástica» (é palavra sua), que não raro o desviava dos deveres escolares, "chegava mesmo a apanhar pancada dos professores, mas isso agora transformava-se em elogio à minha vocação». (\$2)

Chegado o grande dia, é com certa emoção que o jovem Luciano se dirige à oficina do tio, a fim de iniciar a sua nova vida. De resto, via no ofício de escultor uma espécie de brincadeira de certo modo agradável, e até uma forma de se distinguir perante os amigos, quando estes o vissem esculpir figuras de deuses e estatuetas. Todavia, e contrariamente às suas esperanças, o começo foi desastroso. O tio póe-lhe na mão um escopro e manda-o desbastar uma placa de mármore, a fim de adiantar trabalho $(" O$ começar é meio caminho andado»). Ora... uma pancada um pouco mais forte, e eis que se quebra a placa... donde uma monumental sova de correia, que só a fuga consegue interromper. Corre para casa em tal estado, que a mãe não pode deixar de censurar asperamente a brutalidade do irmáo. Entretanto, aproxima-se a noite, e o moço, ainda choroso, dolorido e revoltado, foi deitar-se. As fortes emoçôes do dia tiveram como resultado um sonho - donde o título da obra. (\$\$ 3-4)

Até aqui, Luciano fornece-nos dados objectivos, que nos permitem formar uma ideia suficientemente precisa sobre si próprio e sobre a situação e ambiente familiares. Quanto ao sonho, se nada nos permite duvidar da sua ocorrência, a verdade é que se trata, antes de mais, duma elaboração retórica, elemento tantas vezes utilizado na literatura, mas nem por isso menos significativo do ponto de vista autobiográfico. De facto, Luciano serve-se deste processo para revelar aos seus ouvintes não tanto o que se terá passado nessa noite, mas principalmente a volta que a vida dera, a partir duma situação que, em princípio, teria uma sequência bem diferente. 
Assim, e com uma nitidez - segundo afirma - «em nada diferente da realidade», aparecem-lhe duas mulheres, que, energicamente e até com grande violência, disputam a posse do moço, que passa duma para a outra, e volta à primeira... enfim, "pouco faltou para que me despedaçassem".

Uma delas era a Escultura (Hermoglyphikéo), «com o (típico) aspecto de operário, viril, de cabeleira sórdida, mãos cheias de calos, manto subido e coberto de pó, como meu tio quando estava a polir as pedras». A outra era a Cultura (Paideia), «de fisionomia extremamente agradável, pose digna e manto traçado a preceito». (\$\$ 5-6).

Seguem-se os discursos de cada uma das personagens, que fazem lembrar o agóón («luta», "disputa») das Nuvens de Aristófanes, travado entre a Tese Justa e a Tese Injusta.

A fala da Escultura, mais curta (\$\$ 7-8), contém, no entanto, elementos biográficos (explícitos e implícitos) de certa importância. Começa por se referir à tradição profissional da família do jovem, cujo avô materno e dois tios, também maternos, eram escultores de mérito. A seguir, enumera as vantagens da profissão: comida farta, ombros fortes e, sobretudo, uma vida particular ao abrigo de invejas e intrigas, em vez de (como, de resto, veio a suceder - daí também o valor biográfico da informação) viagens por países longínquos, afastado da pátria e dos amigos. De resto, a História está cheia de exemplos de grandes escultores (Fídias, Policlito, Míron, Praxíteles), cujo nome é imortal e que são reverenciados juntamente com as estátuas dos deuses por eles criadas.

O discurso da Cultura ( $\$ \$ 9-13$ ) possui todos os ingredientes necessários à vitória (além das informaçóes biográficas que recolhemos das suas "profecias»... já realizadas). Vejamos alguns passos.

"Meu filho: eu sou a Cultura, entidade que já te é familiar e conhecida, muito embora ainda não me tenhas experimentado completamente. "Quanto aos grandes beneficios que te proporcionará o ofício de escultor, já esta aqui os enumerou: não passarás dum operário que mata o corpo com trabalho e nele depóe toda a esperança da sua vida, votado ao anonimato e ganhando um salário magro e vil, de baixo nivel intelectual, socialmente isolado, incapaz de defender os amigos ou de impor respeito aos inimigos, de fazer inveja aos teus concidadãos. Apenas isto: um operário, um de entre a turba, prostrado aos pés dos poderosos, servidor humilde dos bem-falantes, levando uma 
vida de lebre, presa do mais forte. E mesmo que viesses a ser um outro Fidias ou um Policlito, mesmo que criasses muitas obras-primas, seria apenas a obra de arte aquilo que toda a gente louvaria, e ninguém de bom senso, entre os que a contemplassem, ambicionaria ser como tu. Sim: por muito hábil que sejas, não passarás dum artesão, dum trabalhador manual.

"Se, porém, me deres ouvidos, antes de mais revelar-te-ei as numerosas obras dos antigos, falar-te-ei dos seus feitos admiráveis e dos seus escritos, tornar-te-ei um perito em, por assim dizer, todas as ciências. Equanto ao teu espírito - que é, afinal, o que mais importa -, exorná-lo-ei com as mais variadas e belas virtudes: sabedoria, justiça, piedade, doçura, benevolência, inteligência, fortaleza, amor do Belo e paixáo do Sublime. Sim, que tais virtudes é que constituem verdadeiramente as incorruptiveis jóias da alma...

“... Tu, agora pobre, tu, o filho do Zé-ninguém, tu, que ainda há pouco havias enveredado por um ofício tão ignóbil, dentro em breve serás admirado e invejado por toda a gente, cumulado de honrarias e louvores, ilustre por tua alta formação, estimado das elites de sangue e de dinheiro; usarás um traje como este (e apontava-me o seu, que era realmente magnífico) e gozarás de merecido prestígio e distinção. E sempre que saias da tua terra, vás para onde fores, não serás, lá fora, um obscuro desconhecido: impor-te-ei tal marca, que, ao ver-te, um qualquer, dando de cotovelo ao vizinho, apontar-te-á com o dedo, dizendo: "É este, o tal"..."

O final do discurso ( $\$ 13)$ constitui um autêntico "fecho" elaborado segundo as leis da retórica. Depois de, no parágrafo anterior, ter mencionado os exemplos de Demóstenes (filho dum fabricante de armas), de Ésquines (cuja mãe era tocadora de pandeireta) e de Sócrates (filho de escultor), lança o ataque final:

"Caso desprezes o exemplo de tão ilustres homens, seus feitos gloriosos e escritos veneráveis, presença imponente, honra, glória e louvores, supremacia, poder e dignidades, fama literária e o apreço devido à inteligência - então passarás a usar uma túnica reles e encardida, ganharás um aspecto servil, agarrado a alavancas, cinzéis, escopros e goivas, completamente inclinado sobre o trabalho, rastejante e rasteiro, humilde em todas as acepçóes da palavra, sem nunca levantar a cabeça, sem um único pensamento digno dum homem livre, mas antes continuamente preocupado com a ideia de a obra te sair harmoniosa e apresentável - enquanto a respeito de ti próprio, da maneira de te tornares harmonioso e bem dotado, náo te importas absolutamente nada; pelo contrário, ficarás mais vil que as mesma pedras." 
É pena que esta autobiografia não tivesse sido escrita uns vinte (ou trinta) anos mais tarde. Em todo o caso, Luciano, noutras obras, fornece-nos mais algumas indicaçóes.

Assim, pela Dupla Acusação (\$27), escrita pouco depois do Sonho, sabemos que Luciano, entregue de alma e coração à retórica e à sofística, iniciara a sua actividade de advogado em várias cidades da Ásia Menor (Segundo a Suda, «começou por ser advogado em Antioquia»). Da Ásia Menor, passa para a Grécia, e daí para a Itália, mas é sobretudo na Gália que obtém glória e fortuna.

Uma dúzia de anos depois de ter saído da sua terra natal, regressa a casa, mas por pouco tempo. Decide fixar-se com a família em Atenas, onde permanece por cerca de vinte anos (c.165-185 d.C.).

Aos quarenta e poucos anos, Luciano adopta uma atitude fundamentalmente céptica, que, sobretudo, se insurge contra todo o dogmatismo metafísico e filosófico em geral. A este respeito, recomenda-se vivamente a leitura do Hermotimo (ou As Seitas $^{2}$ ), obra dum niilismo verdadeiramente perturbador: Dada a variedade das correntes filosóficas, e ainda devido ao tempo e esforço necessários a uma séria apreciação de cada uma, o homem, por mais que faça, não pode atingir a verdade. Basta citar uma frase, que, não sendo de modo nenhum a mais importante deste diálogo, é, no entanto, verdadeiramente lapidar: "As pessoas que se dedicam à filosofia lutam pela sombra dum burro" (\$71). E, já agora, aqui fica o fecho, em que Hermotimo, finalmente convencido pelos argumentos de Licino (ou seja, Luciano), afirma: "Quanto aos filósofos, se por acaso, e apesar das minhas precauçóes, topar com algum no meu caminho, evitá-lo-ei, fugirei dele como dum cão raivoso». (\$ 86)

Cerca de vinte anos depois de chegar a Atenas, Luciano decide recomeçar a viajar, mas nada será como antigamente: já na recta final da existência, talvez em situação financeira menos próspera, e sem dúvida desiludido com o deteriorado clima cultural de Atenas, fixa-se no Egipto, onde aceita (ou consegue?) um lugar de funcionário público, aliás compatível com a sua formação e importância social. Ele próprio nos informa (Apologia dos Assalariados, $\$ 12$ ) de que a sua situação não se compara à dos miseráveis funcionários (por exemplo: professores), que afinal náo passam de escravos. E continua:

\footnotetext{
${ }^{2}$ «Clássicos Inquérito», n 16.
} 
"A minha condição, meu caro amigo ${ }^{3}$, é completamente diferente. $\mathrm{Na}$ vida privada, conservei toda a minha liberdade; publicamente, exerço uma porção da autoridade suprema, que administro em conjunto com o procurador ... Tenho sob a minha responsabilidade uma parte considerável da provincia do Egipto, cabe-me instruir os processos, determinar a ordem pela qual devem dar entrada, manter em dia os registos exactos de tudo o que se diz e faz, ... executar integralmente os decretos do Imperador ... Ealém do mais, o meu vencimento não se parece nada com o dum simples particular, mas é digno dum rei, e o seu montante, longe de ser módico, ascende a uma soma considerável. A tudo isto acrescenta o facto de eu não me alimentar de esperanças modestas, pois é possivel que ainda obtenha a título pleno a prefeitura ou qualquer outra função verdadeiramente real.»

Esperanças nada modestas, provavelmente bem fundadas... Só que, por motivos que ignoramos, tudo se desfez em vento.

${ }^{3}$ Esta obra, de forma epistolar, é dirigida a Sabino, amigo de Luciano. 


\section{Heródoto ou Aécion}


(Página deixada propositadamente em branco) 


\section{INTRODUÇẤO}

Este opúsculo de Luciano inclui-se no grupo de obras que servem de prefácio a uma declamaçáo de fundo, e que eram justamente chamadas prolalíai ( $\left.\pi \rho \circ \lambda \alpha \lambda i \alpha_{1}\right)$ ), "prefácios", "alocuçôes prévias", como, p.ex., os opúsculos Dioniso, Héracles, Zêuxis ou Antíoco, etc. Quer dizer: o orador, antes de começar a dissertar sobre determinado tema, dirigia ao público umas palavras de preparaçáo dos espíritos para o que ia ser tratado como tema de fundo. Acontecia, porém (pelo menos, mas não só, certamente, com Luciano), que o orador, querendo mostrar o seu virtuosismo intelectual, começa por dissertar sobre um ou diversos casos, que aparentemente náo têm nada que ver com o tema proposto e previamente anunciado. Muitos ouvintes perguntariam "aonde é que ele quer chegar, que se ligue ao tema anunciado?” Neste caso, Luciano atira para o meio dos ouvintes dois nomes bem conhecidos: O historiador Heródoto e o pintor Aécion.

De Heródoto, conta o episódio em que o historiador, querendo tornar a as suas Histórias imediatamente conhecidas de toda a Grécia, se apresenta no local mais concorridos de todos, a cidade de Olímpia por altura dos Jogos Olímpicos. E do mesmo modo procedeu o pintor Aécion, ao expor, também em Olímpia, o seu magnífico, e certamente grande ou grandioso, quadro sobre As Bodas de Roxana e Alexandre., quadro que, aliás, Luciano afirma ter visto na Itália, e que descreve com algum pormenor. Por estes dois actos de "promoção", ambos, Heródoto e Aécion, conseguiram aquilo por que tanto ansiavam... com algum benefício "extra" para o pintor, que acrescentou ao casamento de Alexandre, pintado, o seu próprio enlace (real) com a filha do helanódice Proxénides.

É entáo que Luciano descobre a subtileza: Também ele, querendo tornar-se rapidamente conhecido de muitos gregos de diversas cidades, apresenta, na capital da Macedónia e perante uma multidáo que acorrera ao estádio por altura de uma festa desportiva e religiosa, um seu discurso, que presumimos ser bastante elaborado...

E termina mui modestamente, dizendo que, sem querer comparar-se a famosos atletas dos tempos passados, já ficaria muito consolado, se os ouvintes não o considerassem merecedor de chicote...

Presume-se que, neste ponto... final, os ouvintes sorririam da "habilidade" e se disporiam a escutar, com ouvidos benevolentes, o tema anunciado. 
(Página deixada propositadamente em branco) 


\section{Heródoto ou Aécion}

1. Oxalá eu pudesse imitar as diversas qualidades de Heródoto! Náo digo todas quantas ele possuía, pois seria pedir demasiado, mas, pelo menos, uma de entre todas, como a graça das expressóes, ou a sua harmonia, ou a propriedade e a adequaçáo do seu dialecto jónico, ou a riqueza de pensamento, ou mil outras qualidades que ele reuniu num todo e estáo para lá da nossa esperança de poder imitá-las. Mas o que ele fez com os seus escritos, e como se tornou, em pouco tempo, muito apreciado por todos os Gregos, isso é o que eu, e tu, e outro qualquer poderemos imitar.

De facto, tendo viajado por mar desde a sua terra natal, na Cária, com destino à Grécia, reflectia consigo mesmo sobre a maneira de se tornar, o mais rapidamente possível e com o mínimo de incómodo, famoso e afamado, ele próprio e os seus escritos. Considerava ele que andar de terra em terra a recitar sucessivamente a sua obra, ora para os Atenienses, ora para os Coríntios, ou para os Argivos, ora para os Lacedemónios, era muito trabalhoso e muito demorado, e náo seria nada curto o tempo gasto nessa tarefa. É claro que náo julgava adequado dispersar a sua acção, nem, com essa divisão, só a pouco e pouco suscitar e colher reputação. Pelo contrário, planeava, se fosse possível, apanhar reunidos todos os Gregos. Ora, aproximavam-se os grandes Jogos Olímpicos, e Heródoto, percebendo que era chegada a ocasiáo que ele tanto desejava, esperou que a assembleia estivesse cheia, com os mais excelentes dos homens já ali reunidos, vindos de toda a parte, e entáo, surgindo da parte traseira do templo, náo como espectador, mas como concorrente aos Jogos Olímpicos, apresentou-se a si próprio, recitando as suas Histórias, com o que encantou os presentes, a ponto de os seus livros serem intitulados com os nomes das Musas, que eram nove.

2. Daí em diante, já todos o conheciam muito melhor do que aos próprios campeóes olímpicos, e não havia quem náo tivesse ouvido o nome de Heródoto - uns por tê-lo escutado pessoalmente ${ }^{4}$ em Olímpia, e outros por terem sido informados pelos que haviam regressado da festa. Entâo bastava-lhe aparecer

${ }^{4}$ Recorde-se o início das Histórias (Livro I, 1): "De Heródoto de Halicarnasso, eis a apresentação da sua investigação, a fim de que os feitos dos 
em qualquer parte, e logo era apontado a dedo: "Este é o famoso Heródoto, o tal que escreveu em jónico sobre as Guerras Pérsicas, o tal que celebrou as nossas vitórias." Foi este o fruto que ele retirou das suas Histórias, o de, numa única assembleia, ter recolhido o voto unânime de todo o povo da Grécia e de ter sido proclamado, não, por Zeus!, por um único arauto, mas sim em todas as cidades de onde era cada um dos espectadores.

3. Foi por terem, mais tarde, compreendido este facto, ou seja, que era este o caminho mais curto para a notoriedade, que o sofista Hípias, natural dessa mesma região, Pródico de Ceos, Anaxímenes de Quios, Pólo de Agrigento e um grande número de outros recitavam sempre as suas obras pessoalmente e perante uma assembleia de ouvintes, através dos quais se tornavam conhecidos em pouco tempo.

4. Mas para quê citar-te esses famosos antigos, sofistas, historiadores e cronistas, quando se diz que, mais recentemente, o pintor Aécion, tendo pintado o casamento de Roxana e Alexandre, levou a tela a Olímpia, onde expôs o quadro, de tal maneira, que Proxénides, que na altura era "helanódice", deleitado com aquela obra de arte, fez de Aécion seu genro?

5. Mas - perguntaria alguém — que motivo de admiração haveria no seu quadro, para que, por esse facto, o "helanódice" desse a sua filha em casamento a Aécion, que nem era natural da terra? O quadro está na Itália, e eu próprio o vi, de maneira que estou em condiçóes de to descrever. Vê-se um belíssimo aposento e um leito nupcial, e Roxana está nele sentada, cena encantadora de uma jovem de olhos fixos no chão, muito recatada, com Alexandre de pé à sua frente. Alguns Amores ${ }^{6}$ sorriem: um deles, colocado atrás da noiva, descobre-lhe o véu da cabeça e apresenta Roxana ao seu noivo, enquanto um outro, em gesto completamente servil, lhe descalça a sandália do pé, para que ela se deite logo; outro, também Amor, agarrando Alexandre pelo manto, tenta arrastá-lo a toda a força para junto

homens não desapareçam com o tempo...”. Quer dizer; Heródoto identifica-se logo no início da sua leitura pública.

5 "helanódice", ou seja, um dos juízes (e também um dos organizadores) dos Jogos Olímpicos.

6 "Amores", gr. Érōtes ("E $\rho \omega \tau \varepsilon \varsigma)$, em lat. também. Cupido, pl. Cupidinnes. 
de Roxana. O próprio rei oferece uma coroa à jovem, e a seu lado, na qualidade de paraninfo e acompanhante dos noivos, está Heféstion ${ }^{7}$, com um facho aceso na mão e apoiado num formosíssimo adolescente, que julgo ser Himeneu ${ }^{8}$, pois não está lá escrito o seu nome ${ }^{9}$. No outro lado da tela vêem-se outros Amores a brincarem com as armas de Alexandre, em que dois deles carregam com a sua lança, mais parecendo carregadores vergados ao peso de um barrote que transportam; outros dois pegando pelas correias do escudo, arrastam um terceiro, este presumivelmente o seu rei, montado sobre o escudo; e ainda um outro, enfiado por debaixo da couraça que jaz por terra, parece estar de emboscada, no intuito de assustar os outros [três], quando passarem por ele a arrastar [o escudo].

6. De resto, estas representações não são uma [simples] brincadeira, nem Aécion as colocou lá ao acaso, mas, pelo contrário, ele mostra não só a paixão de Alexandre pelas coisas da guerra, mas também que, ao mesmo tempo que ama Roxana, não está esquecido das armas. Além disso, o próprio quadro [em si mesmo] distingue-se por conter algo de verdadeiramente nupcial, por ter como que preparado o casamento de Aécion com a filha de Proxénides. Assim, Aécion saiu de lá também ele casado, como sequência das bodas de Alexandre, tendo o rei como seu "paraninfo" e depois de receber, como paga do casamento pintado, um casamento verdadeiro.

7. Portanto, Heródoto - e a ele regresso - considerou que a festa dos Jogos Olímpicos era bastante [apropriada] para revelar aos Gregos um admirável historiador, que narrava as vitórias gregas da maneira como ele as havia narrado. Ora eu — pelo [Zeus] Fílio! ${ }^{10}$, não cuideis que eu estou louco, ao comparar os meus escritos com os seus, que esse homem me perdoe - , afirmo que acontece comigo o mesmo que com

${ }^{7}$ Heféstion, general de Alexandre.

${ }^{8}$ Himeneu é o deus que conduz o cortejo nupcial. Segundo uma tradição, era filho de Apolo e de uma Musa (Calíope, Clio ou Urânia); outra versão dá-o como filho de Dioniso e Afrodite.

${ }^{9}$ Muitos quadros (também vasos) tinham a identificação das personagens representadas. Aqui, a sobrecarga de figuras tornava difícil encontrar espaço para todas as identificaçóes.

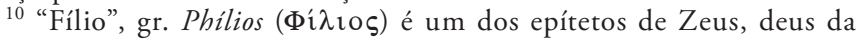
amizade. 
aquele. De facto, ao deslocar-me pela primeira vez à Macedónia, reflectia comigo mesmo no que seria [mais] útil ao meu caso. O meu grande desejo era tornar-me conhecido de todos vós e revelar as minhas obras à grande maioria dos Macedónios. Mas, andar por aí, nesta altura do ano, a visitar pessoalmente cada cidade muito cómodo; se, porém, eu esperasse por esta vossa assembleia geral e apresentasse e proferisse em público o meu discurso, o meu desejo concretizar-se-ia com êxito.

8. Pois agora já estais aqui reunidos, vós, a fina-flor vinda de cada uma das cidades, o autêntico escol de todos os Macedónios, e acolhe-me aquela que é a sua mais excelente cidade, a qual, por Zeus!, não se compara com Pisa ${ }^{11}$ e o seu espaço apertado, as suas tendas, as suas barracas e o seu calor sufocante. Mas os presentes nesta assembleia náo constituem uma populaça indistinta de homens mais desejosos de ver os atletas, e que na sua maioria colocam Heródoto em segundo plano, mas, pelo contrário, trata-se dos mais conceituados oradores, historiadores e sofistas, além de que já não é coisa pouca o facto de este espaço ${ }^{12}$ não me parecer muito inferior ao dos Jogos Olímpicos. Se vós me comparardes a Polidamante, a Glauco ou a Mílon ${ }^{13}$, eu parecerei, a vossos olhos, um homem completamente atrevido, mas se afastardes a lembrança daqueles [atletas] e olhardes só para a minha pessoa como ela é, talvez eu não vos pareça muito merecedor do chicote. Assim, num estádio como este, mesmo este julgamento ${ }^{14}$ já me bastaria.

${ }^{11}$ Pisa, cidade da Élide (não a Pisa italiana).

12 "este espaço", deve referir-se ao estádio.

13 Atletas famosos.

14 "este julgamento", ou seja, o de, simplesmente, não considerar Luciano merecedor de chicote, como se diz imediatamente antes. 
ZêuXis ou Antíoco 
(Página deixada propositadamente em branco) 


\section{INTRODUÇẤO}

Trata-se de mais uma prolalía $(\pi \rho \circ \lambda \alpha \lambda i ́ \alpha)$, ou prefácio a uma declamação de fundo, na qual o orador vai buscar um ou mais temas que, aparentemente, pouco têm que ver com a intervenção de fundo. No fim, com uma habilidade nem sempre muito feliz, o orador desvenda a associação da sua alocução com o tema principal.

Neste caso, Luciano chama à colação duas figuras importante: o pintor Zêuxis e o rei Antíoco.

Zêuxis pintou, entre outros motivos pouco ou nada habituais, um quadro em que representava, numa tocante cena familiar, uma bela Hipocentaura — tão bela na parte equina como formosa na parte de mulher - a amamentar dois meninos gémeos (um na teta humana, outro na teta equina!), sob o olhar baboso e brincalhão do pai Hipocentauro. Ora, os espectadores apreciavam somente a novidade da ideia, sem atenderem aos aspectos propriamente artísticos — o que deixou Zêuxis sumamente irritado...

No caso de Antíoco, Luciano refere a famosa batalha travada contra os Gálatas (276 a.C.), em que Antíoco obteve uma vitória retumbante devido à utilização de dezasseis elefantes, e não por mérito dos seus soldados, os quais, aliás, nem chegaram a entrar em combate. Devido a esse triunfo, Antíoco foi aclamado e cognominado Sóter, gr. Sōtéor ( $\Sigma \omega \tau \eta \dot{\rho})$, ou seja, "Salvador". Na verdade, o epíteto caberia bem mais justamente aos elefantes, mas também ao estratego Teódotas, que teve a ideia salvadora. Para Luciano, é mais um caso de mérito indevidamente atribuído.

No último parágrafo $(\$ 12)$, misturando os dois casos anteriores com o seu próprio, Luciano teme que os ouvintes só vejam nas suas obras o aspecto exterior, tantas vezes bizarro, e não reparem na arte propriamente literária. Mas, felizmente, não é o seu caso, "pois vós sois bons conhecedores de 'pintura' [leia-se: de literatura] e olhais cada pormenor segundo as regras da arte. Basta que tais obras sejam dignas de serem mostradas num teatro". 
(Página deixada propositadamente em branco) 


\section{ZêuXIs ou AnTíoco}

1. Recentemente, depois de ter pronunciado perante vós um discurso, regressava a casa, quando, aproximando-se de mim muitos dos meus ouvintes — nada me impede, creio eu, de vos contar o sucedido, a vós que já sois meus amigos - ... aproximando-se, pois, de mim, não deixavam de me saudar e de mostrar a sua admiração. Acompanhando-me durante muito tempo, uns de um lado, outros de outro, soltavam exclamaçóes e elogiavam-me, a ponto de eu ficar ruborizado, por receio de estar muitíssimo longe de merecer tais elogios. Ora, a essência [dos elogios] consistia — facto que todos unanimemente assinalavam — na conceptualização, realmente estranha, das minhas obras, e na novidade nelas contida... Mas talvez seja melhor citar as expressóes que eles proferiam: "Oh, que novidade! Por Héracles!, que paradoxos! Que homem tão inventivo! Ninguém seria capaz de exprimir um pensamento mais original!" E diziam muitas outras coisas deste género, ou seja, como tinham ficado emocionados com a minha leitura. Sim, que motivo teriam eles para mentir daquela maneira e lisonjear um estrangeiro, um homem que, em tudo o mais, não merecia a sua especial atenção?

2. Em todo o caso, o elogio desses homens - realmente, haverá que dizê-lo - afligia-me, e não pouco, e então, logo que eles se retiraram e eu fiquei a sós comigo mesmo, pus-me a pensar no seguinte: Será que ${ }^{15}$ nas minhas obras existe este único encanto, que consiste em não serem rotineiras e em não pisarem a via comum às outras, ao passo que os belos vocábulos nelas contidos e conformes com as regras antigas, ou a agudeza de espírito, ou uma certa finura, ou o encanto do dialecto ático, ou a harmonia, ou a arte inerente a todas essas minhas obras —... será que essas qualidades estarão porventura arredadas [dos meus escritos]? Na verdade, as pessoas não teriam omitido estas qualidades, elogiando somente a novidade e a estranheza do meu estilo. Eu, porém, o tolo, cuidava que, quando os ouvintes se levantavam e aplaudiam, talvez fosse, sim, também esta qualidade que os seduzia, e que era verdadeiro o pensamento de Homero, segundo o qual um

15 Interpreto o período como interrogativo, cuja resposta implícita deverá ser negativa... 
canto novo torna-se agradável aos que o escutam ${ }^{16}$. No entanto, eu não pretendia atribuir tanto valor, ou mesmo todo [o valor], à novidade, mas sim associá-la às outras qualidades como parte adicional, que contribuísse, também ela, para o elogio, mas [pensando que] as [qualidades] realmente elogiadas e aplaudidas pelos ouvintes eram aquelas outras. Assim, fiquei todo vaidoso e estava a ponto de acreditar nesses homens, que diziam que eu era único e ímpar entre os Gregos, e mais coisas do género. Todavia, e segundo o provérbio, "o nosso tesouro eram carvóes", e pouco faltou para ser por eles elogiado com o elogio feito a um qualquer charlatão.

3. Mas quero agora contar-vos o caso de um pintor. O famoso Zêuxis, que se tornou o mais excelente dos pintores, não pintava esses temas populares ou banais, ou, mas só muito raramente, heróis, deuses e guerras, mas, pelo contrário, esforçava-se sempre por ser original, e então, sempre que pensava num tema bizarro e estranho, aplicava nele a precisáo da sua arte. Ora, entre outras obras arrojados, o dito Zêuxis pintou um Hipocentauro fêmea ${ }^{17}$ a amamentar dois Hipocentauros meninos, gémeos e ainda bebés. Existe actualmente em Atenas uma cópia deste quadro, feita a partir daquele, e com as suas exactas dimensóes. Quanto ao próprio original, diz-se que o general romano Sula o enviou, juntamente com outros [quadros], para a Itália, mas então, como o navio tivesse naufragado, creio que por altura do cabo Málea, perdeu-se tudo, incluindo essa tela. Em todo

${ }^{16}$ Luciano cita em paráfrase e em linguagem "moderna” Odisseia, I, 351-352.

${ }^{17}$ Os Centauros (aqui designados por Hipocentauros, pois também havia os Ictiocentauros) eram seres monstruosos, homens da parte de cima (ou da frente), e cavalos da parte de baixo (ou de trás). De notar que tinham as quatro patas de cavalo, e os dois braços humanos. Viviam nas montanhas, e eram seres extremamente rudes e violentos, e alimentavam-se de carne crua. "Naturalmente", imaginou-se que tinham as suas fêmeas; uma delas é aqui designada, à falta de uma forma feminina, por "Hipocentauro fêmea", mas um autor, Filóstrato (nascido em c. 196 d.C., portanto posterior a

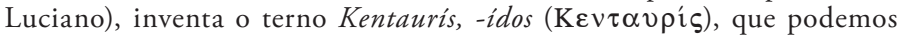
adaptar para port. Centáuride. Também náo seria descabido dizer, em port., ${ }^{*}$ Centaura ou *Hipocentaura. Em todo o caso, Luciano opta por não "mexer" na palavra, precisando o sexo com a indicação "fêmea". No entanto, mais adiante (início do $\$ 4$ ), sem alterar a forma, mas antepondo-lhe

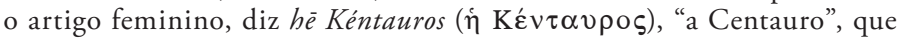
então verto, decididamente, por "a Centaura". 
o caso, eu próprio vi a cópia do quadro, pelo que, na medida do possível, vou descrevê-lo para vós em palavras, pois, por Zeus!, não sou pintor, mas recordo-me perfeitamente, por tê-lo visto não há muito tempo em casa de um pintor em Atenas. Mas o facto de, nessa ocasião, ter admirado muitíssimo essa obra de arte talvez me ajude a descrevê-la com maior precisão.

4. Esta Centaura está pintada sobre uma relva viçosa, com toda a parte da égua assente no chão e com as patas traseiras completamente estendidas. A sua parte de mulher, levemente erguida, está apoiada num cotovelo. As patas da frente não estão direitas, como as de um animal deitado de lado, mas uma delas está dobrada, com o casco puxado atrás, como de uma pessoa que se ajoelha, enquanto a outra está a endireitar-se, apoiada no chão, como fazem os cavalos que tentam levantar-se. Tem nos braços um dos bebés, que ela amamenta à maneira humana, oferecendo-lhe a teta de mulher, enquanto o outro bebé mama da teta da égua, à maneira dos potros. Na parte superior da tela, como de um miradouro, está um Hipocentauro (obviamente marido daquela que está a dar de mamar das duas maneiras aos bebés), inclinado para baixo e sorridente, não completamente visível, mas só até meio da parte de cavalo, e segurando na mão direita uma cria de leão, que ele agita no ar à volta da sua cabeça, para amedrontar os bebés por brincadeira.

5. No que respeita aos outros aspectos da pintura, apesar de não serem completamente discerníveis para um leigo como eu, mesmo assim apresentam toda a força da arte, como a precisão do traço sem descontinuidade, a mistura ${ }^{18}$ exacta das cores e a sua feliz combinação, o criterioso jogo de sombras, a proporção das dimensóes, o equilíbrio e a harmonia das diversas partes relativamente ao conjunto — todas essas qualidades, que sejam os pintores a elogiá-las, aos quais pertence, por ofício, perceber de tais matérias. Pela minha parte, elogiei em Zêuxis somente o facto de ele, numa única e mesma temática, ter patenteado, de forma muito variada, a riqueza da sua arte, ao pintar um

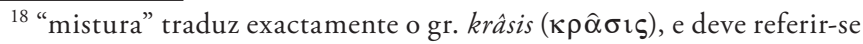
mesmo à mistura de diversas cores, a fim de obter a cor e o tom adequados. A interpretação por "combinação", ou seja, diversas cores em separado e em confronto, não parece poder deduzir-se da palavra grega krâsis, mas talvez corresponda à qualidade mencionada logo a seguir. 
homem extremamente aterrador e selvagem, orgulhoso da sua crina, peludo em quase todo o corpo, não só na parte do cavalo, mas também no peito do homem e em grande abundância na parte dos ombros; o seu olhar, ainda que sorridente, era selvagem, todo ele serrano e indomável.

6. Tal era o Centauro. Quanto à fêmea, era uma belíssima égua, como são especialmente as éguas da Tessália ainda não domadas nem montadas, enquanto a metade superior era de uma formosíssima mulher, com excepção das orelhas, as quais, e somente essas, eram como as dos Sátiros. A mistura e a junçâo dos [dois] corpos, na zona em que a parte equina se funde e se confunde com a parte da mulher, é gradual, sem transiçấo brusca, pelo que a vista, movendo-se lentamente de uma parte para a outra, não se apercebe [da mudança], Quanto aos recém-nascidos, também me pareceu digno de espanto, num bebé, o seu aspecto selvagem e, numa criancinha tenra, o seu aspecto já aterrador, bem como o facto de olharem para cima e de maneira bem infantil para o leâozinho, ao mesmo tempo que cada um deles mamava na teta, agarrado ao corpo da mãe.

7. Ao expor este quadro, Zêuxis cuidava que iria espantar, pela arte em si mesma, aqueles que o vissem, e realmente as pessoas aplaudiam... sim, que poderiam fazer, perante uma visâo táo bela? Todos, porém, elogiavam sobretudo aquilo que no meu caso recentemente elogiaram os outros, ou seja, a estranheza da invenção e a temática do quadro, como sendo uma coisa nova e desconhecida dos [artistas] anteriores. Então Zêuxis, tendo-se apercebido de que aquilo que lhes interessava era o tema original, que os afastava da arte [do quadro], e que punham em segundo plano o rigor dos pormenores, disse para o seu discípulo: "Vamos, Mícion, cobre $e^{19}$ a tela, e vós carregai com ela e levai-a para casa, pois estes fulanos só elogiam a 'lama' da minha arte e não fazem grande caso dos efeitos de luz, se estes estão correctos e em conformidade com a arte, mas, pelo contrário, a novidade do tema prevalece sobre a fidelidade da execuçáo."

19 "cobre", talvez melhor do que "enrola". Diga-se que se tratava de pintura "de cavalete", em que a tela poderia, de facto, ser enrolada. De toda a maneira, o quadro tinha uma grande dimensão, para ser "transportado às costas" por diversas pessoas. 
8. Foi assim que Zêuxis falou, talvez um tanto irritado. Também com Antíoco, cognominado "Sóter"20, aconteceu, segundo se diz, um caso semelhante, aquando da batalha contra os Gálatas. Se vós assim o entenderdes, contar-vos-ei também como aconteceu esse caso. De facto, sabendo que eles eram corajosos, e vendo também que eram muito numerosos, que a sua falange era firmemente compacta, com os hoplitas na frente de batalha armados de escudos e couraças de bronze e alinhados em vinte e quatro linhas de fundo, e que em cada ala havia vinte mil soldados de cavalaria, e no centro, prontos a avançar, estavam oitenta carros de combate armados de foices $^{21}$, e atrás destes, em número duas vezes superior, carros de dois cavalos. Ao ver tal coisa, Antíoco tinha muito fracas esperanças, pois [considerava $q^{22}$ ] os outros eram, para ele, praticamente invencíveis. De facto, dado que o seu exército tinha sido formado em pouco tempo, chegou ali sem a imponência e sem o valor adequado àquela batalha, e com muitíssimo poucos homens, e mesmo a maioria destes era constituída por peltas$\operatorname{tas}^{23}$ e homens levemente armados. Os soldados de infantaria ligeira constituíam mais de metade do exército. Nestas condiçôes, pareceu-lhe melhor fazer imediatamente umas tréguas e encontrar uma solução honrosa para aquela guerra.

9. Todavia, Teódotas de Rodes, homem corajoso e estratego experiente, não deixou que ele, na sua presença, desanimasse. $\mathrm{Na}$ verdade, Antíoco dispunha ainda de dezasseis elefantes. Então Teódotas disse-lhe que mantivesse os animais escondidos o melhor possível, de modo que não fossem visíveis acima do nível do exército; e logo que o trombeteito desse o sinal de iniciar o recontro e houvesse que lutar frente a frente, e quando a cavalaria dos inimigos avançasse, e os Gálatas, abrindo a falange e afastando-se, dessem passagem aos carros, então que dois grupos de quatro elefantes avançassem sobre as cavalaria de ambos os flancos, enquanto os outros oito atacariam os carros

20 "Sóter" é a forma, aportuguesada segundo as regras, correspondente ao gr. Sōtér $(\Sigma \omega \tau \eta \dot{\rho} \rho)$ "Salvador".

${ }^{21}$ Tratava-se de foices ou gadanhas laterais, que "ceifavam" tudo o que estivesse à frente.

22 "considerava que" verte, de algum modo, o dubitativo hōs ( $\dot{\varsigma}$ ).

${ }^{23}$ Os peltastas eram soldados armados de um escudo redondo, pélté $(\pi \dot{\varepsilon} \lambda \tau \eta)$ e uma lança. 
equipados com as foices e os carros de dois cavalos. Se tudo se passasse deste modo - disse Teódotas —, os cavalos deles entrariam em pânico e, ao fugirem, cairiam sobre os Gálatas. E foi o que aconteceu.

10. Realmente, por nunca antes, nem os Gálatas nem os seus cavalos terem visto um elefante, ficaram de tal modo perturbados com esse estranho espectáculo, que, ainda os animais estavam muito longe, só de ouvirem os seus urros e de verem os seus dentes refulgentes e ainda mais notados em contraste com o escuro de todo o corpo, e também as trombas alçadas em forma de gancho, ainda antes de estarem à distância de um tiro de flecha, deram meia volta e puseram-se em fuga desordenada, os soldados de infantaria trespassados pelas lanças uns dos outros e espezinhados pelos cavalos, que caiam sobre eles, enquanto os carros, dando também eles meia volta na direcção dos seus, chacinavam-nos no meio de muito sangue, e, como diz Homero,

"os carros com estrondo se viravam"24.

Os cavalos, uma vez desviados do caminho direito, e não podendo resistir aos elefantes, sacudiram os cavaleiros e

"vazios carros com fragor puxavam",

retalhando e despedaçando com as foices aqueles, de entre os seus, que colhiam [na passagem]... e muitos eram colhidos no meio de tamanha confusão. Seguiram-se os elefantes, que os espezinhavam, os atiravam a grande altura com as suas trombas e os apanhavam e furavam com as suas defesas... enfim, foram estes animais que deram a Antíoco um triunfo retumbante.

11. Quanto aos Gálatas, uns morreram no meio de tanta carnificina, outros foram feitos prisioneiros, com excepção de muito poucos que conseguiram refugiar-se nas montanhas. Então todos os macedónios que estavam com Antíoco entoaram o péan ${ }^{26}$ e, aproximando-se, uns de um lado, outros de

${ }^{24}$ Homero, Iliada, XVI, 379.

${ }^{25}$ Homero, Ilíada, XI, 160.

${ }^{26} \mathrm{O}$ péan era um canto coral solene, entoado especialmente em honra de Apolo, mas também executado noutras ocasióes, nomeadamente, como 
outro, coroaram o rei e aclamaram-no como "glorioso triunfador". Entáo Antíoco, chorando, segundo dizem, exclamou: "Envergonhemo-nos, ó soldados, para quem a salvação veio de dezasseis animais. É que, se a novidade do espectáculo não tivesse estarrecido os inimigos, que seria de nós comparados com eles?" Depois ordenou que no monumento triunfal não se gravasse outra coisa, senão um elefante.

12. É tempo, pois, de eu cuidar de que a minha situação não seja semelhante à de Antíoco, ou seja, em geral inadequada para a batalha, só com uns quantos "elefantes", uns "espantalhos" esquisitos para aqueles que os viam, enfim, uns truques, pois é isso o que todos elogiam. No que respeita, porém, àquelas qualidades nas quais eu confio, essas não estão lá muito dentro das suas preocupaçóes, mas somente ficam espantados com a representação de um Hipocentauro fêmea, que lhes parece, e é realmente, uma coisa original e monstruosa. Mas quanto ao resto, será que foi em vão que Zêuxis o executou? Não, não foi em vão [no meu caso], pois vós sois bons conhecedores de "pintura” e olhais cada pormenor segundo as regras da arte. Basta que tais obras sejam dignas de serem mostradas num teatro.

aqui, como canto de vitória. 
(Página deixada propositadamente em branco) 
Justificaçáo de um Lapso Dito ao Saudar 
(Página deixada propositadamente em branco) 


\section{INTRODUÇẤO}

Entre as diversas convençôes sociais que, no tempo de Luciano (e não só...) deviam ser respeitadas, contam-se as fórmulas de saudação. Por exemplo, a saudação matinal "canónica”, equivalente ao nosso Bom dia!, era khaîre, pl. khaírete ( $\chi \alpha \hat{\imath} \rho \varepsilon$, $\chi \alpha$ í $\rho \varepsilon \tau \varepsilon)$, literalmente "alegra-te", "alegrai-vos". Entre os Romanos, usava-se, em idêntica situação, salvē, pl. salvète, lit. te "que tenhas saúde", "que passes bem". No entanto, a fórmula khaîre, pl. khairete ( $\chi \alpha \hat{\imath} \rho \varepsilon, \chi \alpha i \rho \varepsilon \tau \varepsilon)$ tinha também outras aplicaçóes (v., além do próprio texto de Luciano, os dicionários, p.ex. o de Bailly)

Outra fórmula de saudação era hügíaine (ííaıve) "que te-

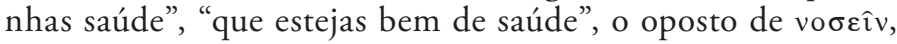
mas também outros usos especiais.

Finalmente, êu práttein ( $\varepsilon \hat{v} \pi \rho \alpha \dot{\tau} \tau \varepsilon \imath v)$ "ser feliz nos negócios", "ter sorte", "ficar bem", "passar bem".

Ora, aconteceu que Luciano, ao saudar matinalmente uma alta personalidade romana em missão (suponho que na província imperial do Egipto, talvez mesmo como Praefectus Aegypti, sendo Luciano alto funcionário na mesma província), não terá usado a fórmula canónica, khaîre ( $\chi \alpha \hat{\imath} \rho \varepsilon)$, "Bom dia!", lit. ${ }^{\text {te }}$ "alegra-te", mas uma espécie de tradução do lat. salvē! "que tenhas saúde!”, ou seja, gr. hügíaine (v̛íaıve) — saudação que, naquela situação e dirigida a uma personalidade importante, e ainda perante muitos homens ilustres, constituía uma autêntica gaffe ou deslize aparentemente imperdoável, que deixou o seu autor muitíssimo envergonhado e o levou a estudar bem o assunto na história da Língua Grega, com o fim de, tanto quanto possível, se justificar. Por isso, lemos abundantes citaçóes dessas três fórmulas, com especial atenção para o famigerado

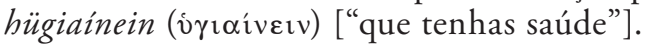

Trata-se, não só, nem principalmente, de uma justificação, mas de uma lição "magistral", uma demonstração de sapiência, como, de resto, o próprio Luciano acaba por confessar, com uma certa dose de cinismo (\$19):

"Aqui chegado, parece-me, e com alguma razão, que tenho mais qualquer coisa que temer, ou seja, que alguns julguem que foi deliberadamente que eu cometi este lapso, no intuito de redigir esta justificação. Pois que assim seja, meu caro Asclépio, que esta minha obra se mostre, não tanto como uma justificação, mas que seja vista como um pretexto para ostentação [do meu saber]." 
E no final do jantar, quando passavam aos discursos inspirados pelo vinho, como:

$$
\begin{aligned}
& \text { Alegra-te', ó Aquiles, de um banquete } \| \\
& \text { pra todos por igual não carecemos }{ }^{27},
\end{aligned}
$$

quando Ulisses se dirigia a Aquiles aquando da embaixada que lhe havia sido enviada. E do mesmo modo, quando as pessoas se despediam uma da outra, como

$$
\begin{array}{r}
\text { Alegrai-vos }{ }^{28}, \text { que vou ser para vós } \| \\
\text { um deus imorredoiro, não mortal }{ }^{9} .
\end{array}
$$

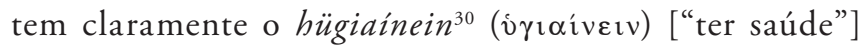
anteposto ao khairrein ( $\chi \alpha$ ípeıv) ["alegrar-se"]. Por outro lado, Aléxis $^{31}$ escreve:

Ó Senhor, 'tem saúde!! Como vens tarde!

em terceiro, alegria, I| e nada a ninguém dever.

Tu, Sauide, a mais augusta $\|$ das felizes divindades, quem dera habitar contigo $\|$ o resto da minha vida!

${ }^{27}$ Homero, Ilíada, IX, 225. A seguir ao farto banquete na tenda de Aquiles, Ulisses exorta o herói a repensar a sua renúncia a entrar na guerra contra Tróia.

28 'Alegrai-vos', aqui, equivale a 'Adeus', 'Passai bem'; o mesmo na citação seguinte.

${ }^{29}$ Hexâmetro dactílico atribuído a Empédocles e dirigido aos seus discípulos, pouco antes de se lançar no Etna.

${ }^{30} \mathrm{Na}$ verdade, o texto homérico tem um sinónimo, imperat. oûle (o $\hat{\lambda} \lambda \varepsilon$ ), "estar intacto", "estar vigoroso"...

${ }^{31}$ Aléxis (c.372-270 a.C.), poeta cómico da "Comédia Média" e da "Comédia Nova", escreveu, segundo a Suda, 245 peças, de que nos restam alguns fragmentos e diversas citaçôes... como esta de Luciano. 


\section{Justificação de um Lapso Dito ao Saudar}

1. Se já é difícil para um ser humano evitar uma maquinação de qualquer divindade, muito mais difícil se torna encontrar justificação para uma falta [cometida] por inadvertência e de inspiração divina, situações essas que acabam, ambas, de me acontecer. Foi o caso que, ao dirigir-me a ti para te dar a saudação matinal, eu, um [homem] de oiro ${ }^{32}$, em vez de te mandar

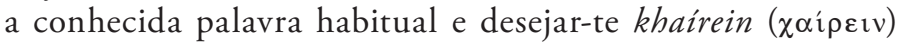
[“alegra-te!”] ${ }^{33}$, desejei-te hügiainein (írıiveıv) ["que tenhas saúde"], fórmula esta também de bom augúrio, mas inadequada para o período da manhã. Logo a seguir, fiquei todo corado e completamente embaraçado, e, entre os presentes, uns pensavam, muito naturalmente, que eu estava louco, outros que eu asneirava devido à minha avançada idade, outros que eu ainda estava toldado pela bebedeira do dia anterior, e só tu reagiste o mais decentemente possível ao sucedido, sem assinalares, nem com uma ponta de riso, o meu lapso de linguagem. Por isso, entendi por bem escrever uma espécie de consolação para mim próprio, para não ficar muito aborrecido com a minha falta e não julgar insuportável o facto de eu, um homem de idade avançada, ter faltado à norma das conveniências diante de pessoas tão distintas. $\mathrm{Na}$ realidade, creio que não era necessária uma justificação em defesa de uma língua que cometeu um lapso, sim, mas ao exprimir um voto de tão bom augúrio.

2. Ora, ao iniciar este escrito, cuidava eu que iria encontrar uma tarefa muito difícil, mas, à medida que avançava, ocorreram-me muitas ideias para dizer. Todavia, não vou expô-las,

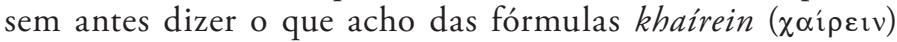
["alegrar-se"], êu práttein ( $\varepsilon \hat{v} \pi \rho \alpha \dot{\tau} \tau \varepsilon \imath v)$ ["ficar bem", "passar

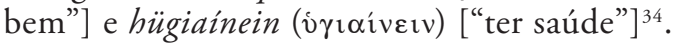

32 "[homem] de oiro", sem a especificação "homem", sugere o "[asno] de oiro" da conhecida história de Apuleio e do próprio Luciano em Lúcio ou $O$ Burro (título que traduzi por Eu, Lúcio - Memórias de um Burro, vol. II das minhas traduçôes). Portanto, Luciano sugere a ideia de "eu, grande asno...”.

${ }^{33}$ Como saudação matinal, a fórmul equivale, aqui, ao nosso Bom dia!

${ }^{34}$ Note-se que as traduçóes destas fórmulas são literais, mas o seu sentido real é outro... 


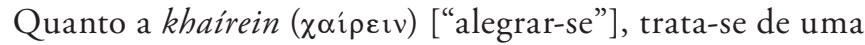
saudação antiga, [de uso] não só matinal e no primeiro encontro [da manhã], pois até mesmo aqueles que se encontravam pela primeira vez a utilizavam, como:

$$
\text { 'Alegra-te }{ }^{35} \text {, ó Senhor } \| \text { desta terra de Tirinte }{ }^{36} \text {, }
$$

Nenhum tempo particular estava atribuído a esta saudação, nem era, como actualmente, exclusivamente matinal, mas usava-se mesmo em situaçôes funestas e abomináveis, como diz o Polinices de Eurípides no momento de abandonar a vida:

\section{'Alegrai-vos', pois da morte $\|$ as trevas já me rodeiam ${ }^{37}$.}

Esta fórmula era um sinal não apenas de amizade, mas também de hostilidade e de separação mútua entre as pessoas.

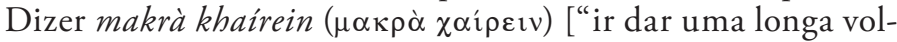
ta", "ir passear", "passar muito bem”, "dizer um longo adeus"] significa que deixamos de nos preocupar com isso.

3. Diz-se que Filípides ${ }^{38}$, fazendo de correio vindo de Maratona, foi o primeiro que, ao anunciar a vitória aos magistrados reunidos e preocupados com o resultado da batalha, disse "Alegrai-vos, vencemos"; e, ao dizer isto, caiu morto juntamente com a notícia e expirou com a palavra khaírein ( $\chi \alpha$ í $\rho \imath \imath)$ ["alegrar-se”]. Cléon, o demagogo ateniense, foi o primeiro que, no início de uma carta enviada de Esfactéria, colocou [a fórmula] khaírein

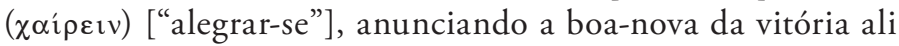
[conseguida] e do aprisionamento dos Espartanos. Depois dele, porém, Nícias, escrevendo da Sicília, continuou com o antigo uso nas cartas, iniciando [a sua carta] directamente com o assunto ${ }^{39}$.

${ }^{35}$ A tradução devia ser "Salve!", mas Luciano tem motivos para interpretar etimologicamente. $\mathrm{O}$ mesmo se diga das traduçóes das outras fórmulas. Nestas condiçōes, dispensar-se-ia a forma métrica das traduçôes, que poderia aplicar-se só com o sentido real das fórmulas, p.ex., "Salve!”...

36 Trímetro jâmbico de um poeta trágico desconhecido.

${ }^{37}$ Eurípides, Fenícias, 1453.

${ }^{38}$ Heródoto dá a este primeiro "maratonista” o nome de Fidipides. Trata-se da vitória dos Atenienses sobre os Espartanos em 424 a.C.

39 "directamente com o assunto", ou seja, sem qualquer fórmula inicial. 
4. Por outro lado, o admirável Platão, conceituado legislador de matérias como esta, aconselha a que se rejeite em absoluto [a fórmula] khaírein ( $\chi \alpha$ ípevv) ["alegrar-se"], por ser de mau gosto e não significar nada de preciso, ao passo que introduz,

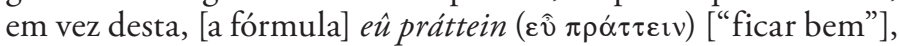
por ser uma fórmula comum ao corpo e à alma, ambos em boas condiçóes. E escrevendo a Dionísio ${ }^{40}$, censura-o pelo facto de, numa composição em honra de Apolo, ele ter saudado o deus com [a fórmula] khaírein ( $\alpha$ ípeıv) ["alegrar-se"], como sendo indigna do Pítio e inconveniente, já não digo para os deuses, mas até mesmo para homens de bom gosto.

5. O divino Pitágoras, embora não se tenha dignado deixar-nos nenhum dos seus escritos, tanto quanto se pode julgar através de Ocelo da Lucânia ${ }^{41}$, de Arquitas e de outros seus discípulos,

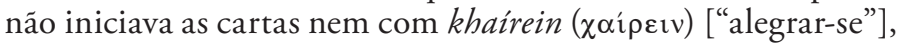
nem com ề práttein ( $\varepsilon \hat{v} \pi \rho \alpha \dot{\alpha} \tau \varepsilon \imath v)$ ["ficar bem"], mas preconi-

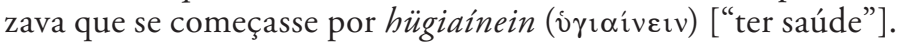
De facto, todos os que eram dessa escola, ao corresponderem-se uns com os outros, sempre que se tratava de assunto sério, escreviam, desejando logo de início, hügiainein (írıíveıv) ["ter saúde"], pois isso era o que mais convinha quer à alma, quer ao corpo, e compreendia o conjunto dos bens do homem. O seu triplo triângulo, lá entre eles o "pentagrama" da mesma seita utilizavam como senha, era por eles designado

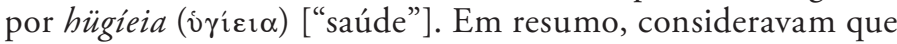

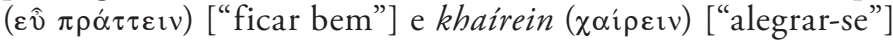

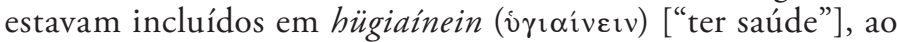

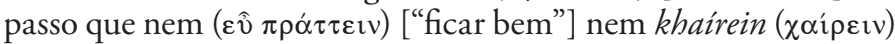
["alegrar-se"] incluíam inteiramente hügiainein (írı́iveıv) ["ter saúde"]. Também há quem [entre eles] considere como o seu juramento mais solene o quatérnion ${ }^{43}$, que para eles constitui o número perfeito, a que chamaram "o princípio da saúde". A este grupo pertence também Filolau.

${ }^{40}$ Dionísio, tirano de Siracusa.

${ }^{41}$ Ocelo da Lucânia, filósofo pitagórico, séc. I a.C. (?); Arquitas de Tarento (séc. IV a.C.), matemático, geómetra e filósofo pitagórico.

42 Pentagrama ou pentalfa $(\Psi)$.

$43 \mathrm{O}$ quatérnion, em gr. tetraktüs ( $\tau \varepsilon \tau \rho \alpha \kappa \rho \hat{\varsigma} \varsigma)$ era o número «10», a soma de $1+2+3+4$, representado por uma figura triangular, em que o vértice tem um (1) ponto, a base quatro (4) pontos e dois níveis intermédios com, respectivamente, dois e três pontos. 
6. Mas para quê falar dos antigos, quando Epicuro, homem que muito apreciava a alegria ${ }^{44}$, escolheu, nas suas cartas mais importantes (das quais possuímos umas quantas, poucas), o prazer acima de todos os bens, mas que, sobretudo nas cartas aos seus amigos mais queridos, coloca logo no início o hügiainein (írı́iveıv) ["ter saúde”]? Também na tragédia e na comédia

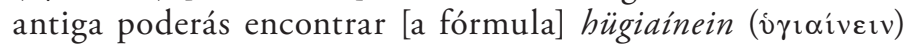
["ter saúde"] dita logo em primeiro lugar. De facto, o verso

'Tem saúde' e 'alegra-te ${ }^{45} \ldots$,

Por outro lado, Aqueu ${ }^{46}$ escreve:

Aqui venho depois de cometer || terrivel acto, e tu, 'tenhas saúde'.

E Filémon ${ }^{47}$ :

Saúde peço primeiro, || logo a seguir bom aspecto,

Realmente, que é que diz o autor do escólio citado por

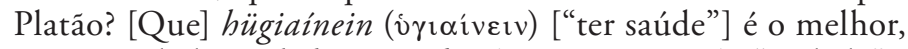

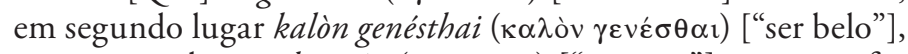
em terceiro lugar plouteîn ( $\pi \lambda$ ov $\tau \varepsilon \hat{\imath} v)$ ["ser rico"], mas não fez

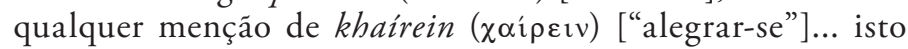
para não te citar aqueles conhecidíssimos versos que andam na boca de toda a gente ${ }^{48}$ :

Assim, se a Saúde é a mais augusta, também a sua função, hügiainein (írı́iveıv) [“dar saúde”], deve prevalecer sobre os outros bens.

7. Embora podendo apresentar-te mil outras citaçôes de po-

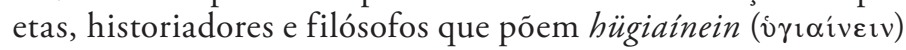
["ter saúde"] em primeiro lugar, renuncio a esse processo, para que este meu escrito não caia numa falta de gosto [própria]

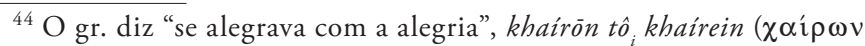
$\tau \hat{\operatorname{Q̣}} \chi \alpha \hat{i} \rho \varepsilon \imath \mathrm{\imath})$.

${ }^{45}$ Homero, Odisseia, XXIV, 402: Palavras do velho servo de Ulisses, Dólio, no regresso do seu amo.

${ }^{46}$ Aqueu, poeta trágico posterior a Sófocles.

${ }^{47}$ Filémon, poeta da Comédia Média.

${ }^{48}$ Versos atribuídos a Árifron (poeta lírico, séc. IV a.C.), início de um

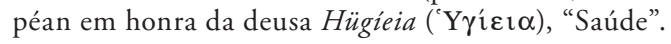


de adolescente e nos arrisquemos a "tirar um prego com outro prego " ${ }^{\prime 49}$. No entanto, vou lembrar-te alguns casos que me ocorrem da história antiga e são adequados à presente situação.

8. Como conta Êumenes de Cárdia na sua epístola a Antípatro, quando Alexandre estava prestes a travar a batalha de Isso, Heféstion, tendo entrado logo de manhã na sua tenda, ou por descuido, ou por perturbação, como me aconteceu a mim, ou devido ao facto de uma qualquer divindade o forçar a isso,

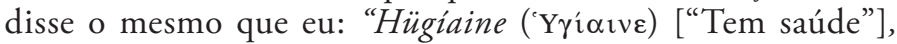
ó rei, está na hora de alinhar as tropas". Como os presentes tivessem ficado perturbados com esta estranha saudaçáo, e como Heféstion ficasse para morrer de vergonha, Alexandre disse: "Aceito o presságio, pois ele anuncia que voltaremos sãos e salvos da batalha."

9. Também Antíoco Sóter ${ }^{50}$, quando estava prestes a entrar em combate com os Gálatas, julgou ver, num sonho, Alexandre debruçado sobre si, ordenando-lhe que desse ao exército, como grito de guerra antes da batalha, o hügiainein (írıíveıv) ["ter saúde"], e foi com este grito de guerra que ele venceu essa batalha.

10. Ptolemeu, filho de Lago ${ }^{51}$, escrevendo a Seleuco, inverteu a ordem, saudando, no início da carta, com hügiainein (írı́iveıv) ["ter saúde"], ao passo que no final, em vez de

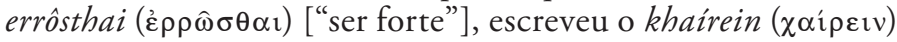
["alegrar-se"], conforme nos diz Dionisodoro, compilador das suas epístolas.

11. Também vale a pena mencionar Pirro, [rei] do Epiro, homem que passa por ser o segundo, a seguir a Alexandre, em assuntos militares e que passou por mil vicissitudes da Fortuna. Ora este, quando orava, ou sacrificava, ou fazia uma oferenda aos deuses, nunca lhes pedia nem a vitória, nem maior poderio

49 "tirar um prego com outro prego", provérbio, que significa "resolver um problema, criando outro”.

50 "Sóter" é a forma, aportuguesada segundo as regras, correspondente ao gr. Sōtêr ( $\Sigma \omega \tau \eta \dot{\rho})$ "Salvador". Note-se que em Zêuxis ou Antíoco, $\$ \$ 8-11$, a vitória de Antíoco sobre os Gálatas foi devida à utilização de dezasseis elefantes...

${ }^{51}$ Ptolemeu, filho de Lago, Ptolemeu I, também cognominado Sóter, como Antíoco. 
real, nem glória, nem excesso de riqueza, mas, pelo contrário, só lhes pedia uma única coisa, hügiainein (írıíveıv) ["ter saúde"], porquanto [acreditava que] ${ }^{52}$, possuindo esse bem, facilmente os outros lhe viriam por acréscimo. E julgo que ele pensava muitíssimo bem, ao considerar que todos os outros bens de nada servem, se lhes faltar este único, hügiainein (íraí veıv) ["ter saúde"].

12. "Pois sim — dir-se-á —, mas actualmente foi por nós estabelecido o tempo próprio para cada uma [dessas fórmulas]; tu, porém, alteraste as coisas, e, mesmo que não tenhas cometido nenhum erro, ainda assim, no que toca ao justo uso do termo, não te livras do lapso, como alguém que pusesse um elmo à volta da perna, ou umas caneleiras à volta da cabeça. "Mas, meu caro - retorquir-te-ia eu —, terias razáo ao dizer tal coisa, caso existisse um tempo que não carecesse de saúde; mas, no caso presente, de manhã, à tarde e à noite, temos sempre necessidade de saúde, especialmente vós, os magistrados e homens de negócios, que, na maior parte dos casos, necessitais de vigor físico. Ora, aquele que disse khaîre ( $\chi \alpha \hat{\imath} \rho \varepsilon$ ) ["alegra-te”], apenas se serviu, logo de início, de uma palavra de bom augúrio, algo que náo passa de um voto, ao passo que aquele que te cum-

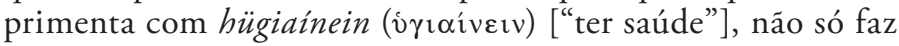
algo de útil, mas também te recorda dos procedimentos que

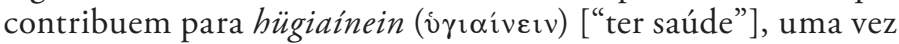
que não se limita a desejar, mas também a aconselhar.

13. E então? No livro de ordens que vós constantemente recebeis da parte do Imperador, náo vem logo em primeiro lugar este conselho, que cuideis da vossa saúde? ${ }^{53}$ E com muita razão. De facto, não resultaria qualquer vantagem, se vós não estivésseis nessa condição [de saúde]. Mas mesmo vós próprios - se é que eu entendo alguma coisa da língua dos Romanos —, estendendo também vós a mão aos que vos saúdam, correspondeis muitas vezes com a palavra hügíeia (íyícı) [“saúde”] 54 .

52 "[acreditava que]" é Luciano a transmitir a crença de Pirro, o que, no texto, está representado por hōs ( $\dot{\omega} \varsigma)$.

53 A fórmula típica entre os Romanos era, p.ex.: CICERO ATTICO SALVTEM.

${ }^{54}$ Trata-se do lat. salve! ou vale atque salve, fórmulas de saudação aqui tomadas etimologicamente no senti do "tem saúde". "passa bem”... 
14. Se disse tudo isto, não foi no sentido de eliminar de-

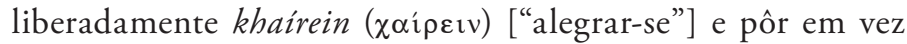

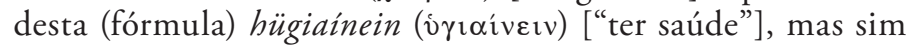
por um lapso involuntário, pois, caso contrário, tornar-me-ia ridículo, ao [pretender] inovar e trocar os tempos das saudaçóes.

15. Até dou graças aos deuses pelo facto de o meu lapso se ter transformado noutra coisa bem mais auspiciosa e eu ter "escorregado" para algo melhor... o que talvez tenha acontecido por inspiração de Higia ${ }^{55}$ e do próprio Asclépio, prometendo-vos,

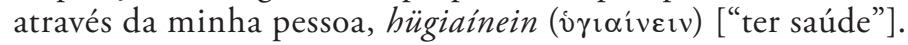
Sim, como é que me aconteceu uma coisa destas, a não ser por acçáo de uma divindade, a mim, que nunca antes, em toda a minha longa vida ${ }^{56}$, me tinha confundido desta maneira?

16. Se, porém, devo apresentar uma justificação humana em defesa do acontecido, [direi que] não é de maneira nenhuma estranho que eu, ao esforçar-me por ser conhecido por ti pelas melhores razóes, me tenha enervado devido a esse tão grande desejo, e tenha caído na situação oposta. Ou talvez me tivesse desviado do recto raciocínio a multidão de soldados, alguns dos quais avançavam acotovelando-se, e outros não permaneciam na fila, na ânsia de se dirigirem a ti ${ }^{57}$.

17. Mas estou convicto de que, apesar de os outros terem atribuído o incidente a ignorância, ou incultura, ou demência minha, tu tomaste-o como sinal de respeito, de simplicidade ${ }^{58} \mathrm{e}$ de espírito que não tinha nada de mundano nem de sofisticado. Sim, que é nesses ambientes que reina o extremo atrevimento,

${ }^{55}$ Higia, gr. Hügíeia ('Y $\gamma^{\prime}$ eıı $\alpha$ ), a Saúde divinizada; Asclépio (o romano Esculápio), filho de Apolo, é o deus da Medicina.

56 "em toda a minha longa vida", expressáo que, juntamente com a informação de que se dirige especialmente a um funcionário imperial (v. $\$ 13)$, aponta para o facto de este escrito datar da fase final da vida de Luciano, como alto funcionário na província imperial do Egipto.

57 Sugiro que esta importante personagem seria o Praefectus Aegypti, ba sua chegada a esta província imperial, onde o alto funcionário Luciano o recebeu com uma saudação inspirada (conscientemente ou não) pela

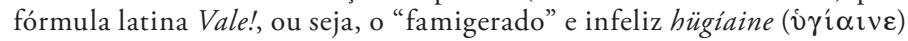
"Tem saúde!", em vez do "canónico” khâ̂re ( $\chi \alpha \hat{\imath} \rho \varepsilon)$, lit. ${ }^{\text {te } ~ " a l e g r a-t e ” . . . ~}$ "Viva!", "Bem-vindo!"...

58 "simplicidade", ou, talvez, "informalidade". 
que não anda longe da insolência e do despudor. Oxalá eu nunca mais cometa semelhante lapso... mas, se tal acontecer, que ele se converta em bom augúrio.

18. Diz-se que no reinado do primeiro "Augusto" 59 ocorreu um caso semelhante a este. Aconteceu que o Imperador, tendo, em certo processo, julgado correctamente e absolvido um homem falsamente acusado de um crime capital, este, agradecendo-lhe em alta voz, disse: "Estou-te reconhecido, ó Imperador, por teres emitido uma sentença tão má e tão injusta.". Então, como os que rodeavam o Imperador tivessem ficado escandalizados e pretendessem despedaçar o homem, o Imperador disse: "Não é a lingua deste homem que devemos considerar, mas sim a sua intenção." Assim falou o Imperador. Também tu, se considerares a minha intenção, acharás que ela te é favorável, mas a própria língua também é auspiciosa.

19. Aqui chegado, parece-me, e com alguma razáo, que tenho mais qualquer coisa que temer, ou seja, que alguns julguem que foi deliberadamente que eu cometi este lapso, no intuito de redigir esta justificação. Pois que assim seja, meu caro Asclépio, que esta minha obra se mostre, náo tanto como uma justificaçâo, mas que seja vista como um pretexto para ostentação [do meu saber].

${ }^{59}$ O primeiro "Augusto" foi Octávio. Este título foi-lhe outorgado pelo Senado em 26 a.C., e passou para todoso os imperadores. 
Harmónides 
(Página deixada propositadamente em branco) 


\section{INTRODUÇÃO}

Luciano compõe uma süstasis ( $\sigma v ́ \sigma \tau \alpha \sigma \imath \varsigma$ ) ou "recomendaçáo", dirigida a uma alta personalidade romana na província da Macedónia, talvez mesmo o seu governador, a fim de obter dele o elogio público do valor da sua produção literária.

Tal como na prolalía ( $\pi \rho 0 \lambda \alpha \lambda i$ í ), ou "prefácio" Heródoto ou Aécion, trata-se de conseguir a máxima glória com o mínimo de incómodo na sua divulgaçáo. Assim - recordo - o historiador Heródoto e o pintor Aécion apresentaram a respectiva obra em Olímpia, por ocasiáo dos Jogos Olímpicos.

Neste opúsculo, Luciano invoca o caso de Harmónides, tocador de flauta, que pede conselho ao seu mestre Timóteo, no sentido de se tornar famoso. A resposta do mestre é algo diferente da "solução" encontrada por Heródoto e Aécion, uma vez que Timóteo, embora sem o afastar das exibiçóes para o grande público, preconiza com muita insistência que o seu discípulo procure antes o elogio das pessoas mais cultas e de maior prestígio, pois estas, com a sua influência sobre as grandes massas ignorantes das coisas do espírito, farão a rápida e efectiva "propaganda" do homem de talento.

Harmónides, infelizmente, não chegou à almejada glória, uma vez que, logo na sua primeira apresentação nas Grandes Dionísias, fez tanto esforço, que exalou em cena o último suspiro.

Luciano decide, pois, apresentar a sua obra a uma alta personalidade da administraçáo romana, confiado em que esta reunia em si como que os "votos" de milhares de pessoas. Era como se concorresse realmente com outros candidatos, contando, porém, se necessário, com o voto de qualidade de um "membro do júri".

Já sabíamos que Luciano tinha, aliás muito justamente, um alto conceito de si próprio, mas necessitava, como tantas vezes acontece, da respectiva "promoção" e do merecido reconhecimento público. 
(Página deixada propositadamente em branco) 


\section{HARMÓNIDES}

1. Harmónides, tocador de flauta, perguntava um dia a Timóteo, seu mestre: "Diz-me cá, ó Timóteo: Como é que eu poderia tornar-me famoso nesta arte? Que é que devo fazer, para que todos os Gregos me conheçam? Na verdade, quanto às outras coisas, já tu me ensinaste... e muito bem, como p.ex. ajustar a flauta com precisáo, soprar algo levemente e harmoniosamente no bocal, colocar os dedos com bom contacto ${ }^{60}$, tanto na arse ${ }^{61}$ como na tese, movimentar-me ritmicamente, executar a música em sincronia com o coro e respeitar as características de cada "modo": o frenesi do modo frígio, a excitaçáo báquica do lídio, a majestade do dórico e a graça do jónio - tudo coisas que eu aprendi contigo. Todavia, o mais importante, aquilo que me levou a optar pela arte da flauta, não vejo como é que, nessa base, o conseguiria, ou seja, a fama na boca de toda a gente, bem como ser assinalado no meio da multidáo e apontado a dedo, e, sempre que aparecesse [em público], todos se voltassem para mim, pronunciassem o meu nome e dissessem: 'É este o famoso Harmónides, o excelente tocador de flauta', tal como tu, Timóteo, quando, tendo saido pela primeira vez da tua terra, na Beócia, acompanhaste à flauta a [tragédia] Pandiónide ${ }^{62}$ e obtiveste a vitória no Ájax Furioso ${ }^{63}$,

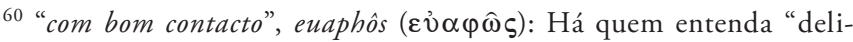
cadamente", mas penso que se trata de colocar firmemente os dedos nos furos da flauta, para que náo saia ar indevidamente.

${ }^{61}$ A arse, ársis (ő $\left.\rho \sigma \iota \varsigma\right)$ é o gesto de "levantar" (o pé, o dedo...), e corresponde, na métrica, a uma sílaba breve, enquanto a tese, thésis ( $\theta \varepsilon \dot{\varepsilon} \sigma \varsigma$ ) significa o movimento contrário e uma sílaba longa. Aqui, trata-se de marcar o compasso.

62 Pandiónide, ou seja "filha de Pandíon". Este, rei de Atenas da dinastia de Erictónio, teve duas filhas, Procne (esposa do trácio Tereu) e Filomela. A lenda, muito escabrosa, diz que Tereu violou a cunhada, e então, para que ela não contasse o caso, cortou-lhe a língua, mas Filomela arranjou maneira de, através de um bordado, contar toda a história. Procne vingou-se do marido, dando-lhe a comer o seu próprio filho, Ítis. Foi a vez de Tereu tentar vingar-se das irmãs, as quais, no entanto, foram salvas pelos deuses, que as transformaram, respectivamente, em rouxinol (Procne) e em andorinha (Filomela). Note-se que, noutra versão, Filomela é que é a esposa de Tereu, e Procne a cunhada por este violada; também se alteram as metamorfoses. Em qualquer dos casos, o tocador de flauta tinha muito que interpretar...

${ }^{63}$ Tragédia de Sófocles, inicialmente musicada por um outro Timóteo (natural de Mileto, 446-356 a.C.), e mais tarde também pelo seu homó- 
da qual o teu homónimo compôs a música, após o que não havia ninguém que náo conhecesse o nome de Timóteo de Tebas. E mesmo aqui e agora, quando tu apareces, correm todos para ti, como os pássaros à volta de uma coruja. Foi nesse intuito que eu ansiei por me tornar tocador de flauta, e foi por isso que eu me tenho esforçado tanto. Na verdade, náo aceitaria o simples facto de tocar flauta sem ser famoso e se com isso continuasse a ser um desconhecido, nem mesmo que viesse a tornar-me um Mársias ou um Olimpo... despercebidos. De facto, como sói dizer-se, de nada serve uma música secreta e oculta. Portanto, peço-te, ensina-me também a maneira de ser útil ao mesmo tempo a mim e à minha arte, e então ficar-te-ei duplamente grato, quer pela arte da flauta, quer - o mais importante — pela glória dai resultante."

2. Então Timóteo respondeu-lhe: "Mas... ó Harmónides, tu anseias por uma coisa que, como bem sabes, não é de pequena monta, como o elogio, a fama, e ser assinalado e conhecido de muita gente, mas, se pretendesses alcançar esse objectivo apresentando-te em demonstraçóes perante multidóes, isso levaria um longo tempo, e nem mesmo assim serias conhecido de toda de toda a gente. Sim, onde se acharia um teatro ou um estádio tão espaçoso, no qual pudesses tocar para todos os Gregos? Mas eu vou dar-te este conselho, para que tu, tendo-o seguido, fiques conhecido deles e assim chegues ao termo do teu desejo. Pois sim, toca a tua flauta, de vez em quando, nos teatros, mas faz pouco caso das multidóes. No entanto, o caminho mais curto e mais fácil que conduz à glória é o seguinte: Na verdade, se escolheres, de entre os Gregos, os mais excelentes, aliás poucos, que são pessoas de topo, indiscutivelmente admiráveis e dignos de crédito em qualquer dos dois pareceres ${ }^{64}$, se — repito - , lhes fizeres uma demonstração das tuas peças de flauta, e se eles te elogiarem, tem como certo que, dentro de pouco tempo, já serás conhecido de todos os Gregos. Ora repara como eu coloco a questão: $N a$ verdade, se aqueles que todos conhecem e admiram reconhecerem que tu és um eximio tocador de flauta, para que precisas tu das multidóes, que, de toda a maneira, seguiráo os que são capazes do melhor julgamento? Realmente, esse povo numeroso

nimo e mestre de Harmónides, e que tocava flauta maravilhosamente para Alexandre Magno...

64 "em qualquer dos dois pareceres", gr. ep’ amphótera ('̇̉' $\alpha \mu \varphi o ́ \tau \varepsilon \rho \alpha)$, ou seja, tanto no elogio como na censura. 
é constituido por pessoas que não têm a noção de beleza, na sua maioria rudes artesáos, que acreditam que aquele que os proeminentes elogiam não foi elogiado sem [uma boa] razão, e por isso também eles o elogiam. De facto, nos concursos públicos, são muitos os espectadores que sabem aplaudir ou assobiar, mas quem julga são sete, ou cinco, ou lá quantos são."

3. Harmónides não chegou a pôr em prática este conselho, pois, segundo se diz, enquanto tocava, na primeira vez em que concorreu, soprou com tanta força, que deu o último suspiro para dentro da flauta e morreu em cena, sem ser coroado, tendo tocado flauta pela primeira e última vez nas Dionísias.

Ora, creio bem que este discurso de Timóteo não se aplica somente aos tocadores de flauta e a Harmónides, mas a todos quantos aspiram à glória, mostrando publicamente algo de si e pedindo o elogio das multidóes. Também eu, por exemplo, quando reflectia em algo semelhante a meu respeito e procurava a maneira de ser o mais depressa possível conhecido de toda a gente, segui o conselho de Timóteo e procurei saber qual era o mais excelente homem nesta cidade, ao qual os outros dessem crédito e que valesse por todos. Assim, foste tu que me pareceste corresponder àquele justo discurso, tu, a súmula de toda a excelência, ou, como sói dizer-se, o padrão e a recta medida dessas matérias. Então, se eu te apresentasse as minhas obras e tu as elogiasses — oxalá elas assim te pareçam! certamente atingiria o cúmulo da minha esperança, ao receber, num só voto, os [votos] de todos. Realmente, quem poderia preferir à tua pessoa qualquer outra, sem ser considerado, e muito justamente, um louco? Assim, em teoria, vou "lançar o dado" 65 dependente de um único homem, mas na realidade é como se convocasse para um teatro comum homens vindos de toda a parte e lhes expusesse as minhas obras. Sim, é óbvio que tu serias superior, quer a cada um separadamente, quer a todos eles juntos. Os reis dos Lacedemónios, enquanto cada um dos outros [cidadáos] dispunha de um único voto, eles, e só eles, dispunham cada um $^{66}$ de dois votos, mas tu

65 "lançar o dado", metaforicamente, significa, afinal, um certo risco, o de fazer depender de um só homem a apreciação da sua obra.

${ }^{66}$ Os Lacedemónios tinham dois reis, com funções sobretudo políticas e militares... 
dispões, além disso, dos votos dos "éforos" ${ }^{67}$ e, também, dos "senadores"... numa palavra, tu, em matéria de cultura, reúnes mais votos que todos os outros, tanto mais que tens sempre o voto branco ${ }^{68}$, aquele que absolve, facto que me dá ânimo na presente situação, embora receoso, e com toda a razáo, devido à grandeza do meu atrevimento. Mas, por Zeus!, aquilo que me dá ainda mais ânimo é o facto de os meus interesses não serem alheios à tua pessoa, uma vez que eu sou natural daquela cidade que tu muitas vezes beneficiaste, primeiro a essa cidade em particular, e depois em conjunto com toda a naçáo ${ }^{69}$. Assim sendo, se porventura, nesse momento, os votos se inclinarem, na contagem, em meu prejuízo e os votos favoráveis forem em menor número, tu, acrescentando o voto de Atena ${ }^{70}$, completa da tua parte o que falta, e que essa correcção seja levada a teu crédito pessoal.

4. $\mathrm{Na}$ verdade, não me basta que muitos me tenham anteriormente admirado, que já seja famoso, que as minhas obras ${ }^{71}$ sejam elogiadas pelos ouvintes. Tudo isso são, como sói dizer-se, sonhos vaporosos, sombras de elogios. Mas é agora que a verdade vai ser revelada, é este o limite exacto das minhas aspiraçóes, já sem qualquer contestação e sem que alguém possa duvidar, mas, pelo contrário, deverei ser considerado o mais excelente

${ }^{67}$ Aqui em sentido figurado, tal como, a seguir, “senadores”.Os éforos eram, em Esparta, em número de cinco, e acabaram por ter um poder superior ao dos próprios (dois) reis. Dirigiam superiormente a política estrangeira e a defesa nacional, os assuntos internos, tinham atribuiçôes judiciais... V. P. Lavedan, Dict. illustré de la mythologie et des antiquités grecques et romaines, "Hachette", 1959, s.u. Éphores.

${ }^{68}$ Cada juiz possuía dois "votos", inicialmente um seixo branco (de absolvição) e um seixo negro (de condenaçáo). Metia na urna "do réu” um dos seixos, e o outro numa segunda urna. Mais tarde, passou a votar-se com duas rodelas de bronze, uma das quais era furada no centro (condenação), de modo que os dedos tapavam essa parte, para que não se visse o furo; a outra rodela (de absolvição) era completamente cheia. Aqui, o "voto branco" funciona como voto de qualidade ou de desempate, como se vê a seguir..

${ }^{69}$ Recorde-se que Luciano era natural de Samósata, capital do antigo reino de Comagena, situado a norte da Síria, na margem direita do Eufrates.

${ }^{70} \mathrm{Nas}$ Euménides de Ésquilo, Atena utiliza o voto de qualidade para salvar Orestes. Em termos latinos, diz-se o voto de Minerva.

71 "obras", lógoi ( $\lambda$ ó yol), incluindo discursos e outras obras em prosa, nomeadamente os discursos de aparato ou declamaçôes (epideixeis, $\varepsilon \dot{\varepsilon} \imath \delta \varepsilon \hat{\imath} \xi \imath \varsigma)$, mas também outras obras lidas e / ou escutadas... 
em termos de cultura, ou [pelo menos], de entre $\operatorname{todos}^{72} \ldots$ Bem... devo usar palavras de bom augúrio ao entrar num concurso tão importante. Ó deuses!, fazei que sejamos dignos ${ }^{73}$ de sermos falados, e confirmai o elogio das outras pessoas, de maneira que, daqui por diante, ousemos apresentar-nos diante das multidôes. Na verdade, todo e qualquer estádio é muito pouco de temer, para quem triunfou nas Grandes Olimpíadas.

72 "de entre todos": Luciano interrompe abruptamente o discurso, que continuaria: "”de entre todos os concorrentes...", como se estivesse a discursar em... Olímpia, o cenário ideal para ser reconhecido por todos. $\mathrm{Na}$ impossibilidade de se apresentar em Olímpia, Luciano contenta-se com o "voto de qualidade" de uma alta personalidade romana (governador da Macedónia?).

73 "de entre todos", etc., plurais majestáticos... para dar mais... majestade ao final do discurso. 
(Página deixada propositadamente em branco) 
Discussáo com Hesíodo 
(Página deixada propositadamente em branco) 


\section{INTRODUÇÃO}

Licino (Luciano) critica a ideia do poeta-profeta, o romano uates, o "vate". Para isso, toma como paradigma Hesíodo, que declara (Teogonia, 31-32), que as Musas lhe haviam inspirado um canto divino, para que ele celebrasse o futuro e o passado. No que respeita ao passado, Licino considera-se satisfeito com a descrição da génese dos deuses e, noutra obra, com a lista das antigas heroínas. Do mesmo modo, não faz grande objecçôes à poesia didáctica sobre a temática da agricultura. O que, porém, o deixa perplexo, e até escandalizado, é o facto de o poeta não nos ter deixado qualquer poema sobre o futuro, o que, para Licino, tem uma de três explicações $(\$ 2)$ : “Ou tu mentiste — coisa amarga de dizer — afirmando que as Musas te teriam prometido que serias capaz de predizer o futuro, ou elas te concederam [esse dom], como haviam prometido, mas tu, por má-vontade, escondes e guardas no teu peito esse dom, não o compartilhando com quem dele necessita, ou então já escreveste muitas obras nesse sentido, mas ainda não as divulgaste em público, reservando o seu uso para uma outra oportunidade."

Hesíodo tenta então justificar-se, atribuindo às Musas as imprecisóes ou omissóes, pois o poeta só se responsabiliza pela matéria de que ele é conhecedor: a agricultura, matéria em que faz certas previsóes muito úteis à vida humana. Além disso, há que dar o devido desconto às liberdades e certas prerrogativas da composiçáo poética.

No que respeita às alegadas previsóes relativas à agricultura, Licino não se deixa iludir, pois náo se trata propriamente de "adivinhaçôes", mas de "conselhos", e, em todo o caso, nessa matéria, os especialistas não são os pastores, como Hesíodo, mas os agricultores.

E fica a crítica de base: Hesíodo, a quem as Musas teriam dado o dom da profecia, não possui, ou pelo menos náo demonstra possuir esse dom.

É subtilmente... manifesto que Licino (Luciano!) póe as maiores dúvidas no poder divinatório dos poetas-profetas... e de todos os poderes divinatórios em geral. Assim, este opúsculo insere-se na onda de cepticismo ou de duro criticismo de ideias e práticas mítico-religiosas. 
(Página deixada propositadamente em branco) 


\section{Discussấo com Hesíodo}

1. LICINO - Que tu, ó Hesíodo, sejas um excelente poeta e que tenhas recebido das Musas esse dom, juntamente com o [ramo de] loureiro, tu próprio o mostras nos versos que compóes, todos eles divinamente inspirados e venerandos, e nós acreditamos que assim seja. Uma coisa, porém, me deixa confuso: Porque é que tu, ao dizeres sobre ti próprio que entáo terias recebido ${ }^{74}$ das divindades esse divino canto, a fim de glorificar e celebrar o passado e profetizar o futuro, cumpriste muito cabalmente uma dessas tarefas - narrando a génese dos deuses, recuando até aos primeiros de entre eles ${ }^{75}$ : Kháos (Xóos)

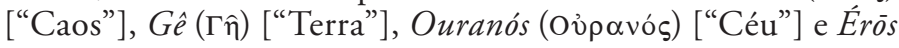

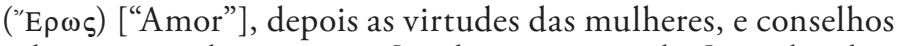
sobre a agricultura, como [conhecimentos sobre] as Plêiades, as épocas próprias para a lavragem, a colheita e a navegação, enfim, sobre todas as outras actividades-, ao passo que, no que toca à outra tarefa, que era de longe a mais útil á vida e mais aparentada com os dons dos deuses - refiro-me à profetização do futuro - , não nos revelaste absolutamente nada, mas deixaste no esquecimento toda essa parte, não imitando, em parte alguma dos teus poemas, Calcante ${ }^{76}$, ou Télemo, ou Poliido, ou Fineu, os quais, sem terem recebido das Musas esse dom, mesmo assim faziam profecias e não hesitavam em proferir oráculos para aqueles que os solicitavam.

2. Assim sendo, é absolutamente forçoso que tu estejas sujeito a uma destas três acusaçóes: ou tu mentiste - coisa amarga de dizer — afirmando que as Musas te teriam prometido que serias capaz de predizer o futuro, ou elas te concederam [esse dom], como haviam prometido, mas tu, por má-vontade, escondes e guardas no teu peito esse dom, não o compartilhando com quem dele necessita, ou então já escreveste muitas obras nesse

74 “terias recebido"... é Licino (Luciano) a falar pelo poeta, mas sem se comprometer...

75 Referência à Teogonia; a seguir, alude ao Catálogo das Mulheres ou (se náo constitui obra à parte) Éốai ("H ô̂ $\alpha \imath$ ) “Ou aquelas...", pois cada exemplo de mulher começava pela frase ̀̀ hoíe ("H oí $\eta$ ) "Ou aquela..."; finalmente, refere-se ao Trabalhos e Dias.

${ }^{76}$ Calcante (ou Calcas), Télemo, Poliido e Fineu eram famosos adivinhos: v. P. Grimal, Dicionário da Mitologia Grega e Romana, Trad. port. de V. Jabouille et alii, "Difel”, 4aed., 2004. 
sentido, mas ainda não as divulgaste em público, reservando o seu uso para uma outra oportunidade. $\mathrm{Na}$ verdade, eu náo me atreveria a afirmar que as Musas, ao prometerem oferecer-te duas coisas, só te deram uma, sonegando-te metade da promessa - refiro-me ao conhecimento do futuro - , tanto mais que prometeram essa parte em primeiro lugar no teu verso ${ }^{77}$.

3. Mas então de que outro, senão de ti mesmo, ó Hesíodo, poderia uma pessoa saber a verdade? De facto, uma vez que os deuses são "dadores de bens"78, conviria que vós, que sois seus amigos e discípulos, nos explicásseis com toda a verdade tudo aquilo que sabeis e desfizésseis as nossas dúvidas.

4. HESÍODO - Eu poderia, meu caro, dar-te uma resposta fácil a respeito de tudo isso, a saber, que nos meus poemas náo há nada [que seja] estritamente meu, mas sim das Musas, pelo que seria a elas que tu devias pedir contas do que [através delas] foi dito ou foi omitido. Eu, propriamente, no que respeita àquelas matérias que particularmente conhecia - refiro-me aos trabalhos e preceitos para o tratamento, pastorícia, condução e ordenha do gado, enfim todas as actividades dos pastores —, estaria em condiçôes de me justificar. Aquelas divindades, porém, transmitem os seus dons a quem entendem e na medida em que consideram por bem.

5. Em todo o caso, não te deixarei sem uma justificação em termos poéticos. Na verdade, não deveis, julgo eu, exigir dos poetas que eles exprimam rigorosa e completamente, até às mais pequenas minúcias, sílaba por sílaba, o seu pensamento, nem criticá-los asperamente, se porventura, ao longo da composição poética, lhes escapa inconscientemente alguma imperfeição, pois deveis saber que nós introduzimos muitas coisas [nos versos], para efeitos quer de métrica, quer de eufonia. coisas essas que, por serem geralmente harmoniosas, o próprio verso, não sei lá

${ }^{77}$ Hesíodo, Teogonia, 31-32: “... inspiraram-me um canto / divino, para que eu celebre o futuro e o passado", lit. " "as coisas que seráo e as que antes

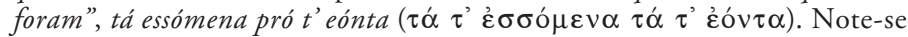
que era essa a ordem pedida pela... métrica, mas Luciano aproveita o facto em proveito da sua tese.

78 "dadores de bens", dōtêres eáōn ( $\delta \omega \tau \hat{\eta} \rho \varepsilon \varsigma$ દ̉ó $\omega \mathrm{v})$, expressão da Odisseia, VIII, 325. 
como, aceita bem. Tu, porém, pretendes retirar-nos a maior das nossas prerrogativas - refiro-me à liberdade e à faculdade criativa. Mas tu não reparas em quantas coisas belas existem na poesia, e então seleccionas umas "aparas" e uns "espinhos" e procuras aí uma "pega” para [sustentar] a tua acusação. E náo és tu o único a fazer críticas corrosivas, nem somente contra mim, pois muitos outros o fazem relativamente ao meu colega Homero, apontando umas coisas muito miudinhas e muitíssimo insignificantes.

6. No entanto, já que tenho de avançar contra a tua acusação e proceder a uma defesa muito directa, lê, meu caro, os meus Trabalhos e Dias, pois ficarás a saber tudo quanto eu, nesse poema, divinatória e profeticamente anuncio, ao mostrar com antecedência os resultados dos trabalhos efectuados correctamente e em seu devido tempo, bem como os danos [causados] por negligência... e então,

numa cesta as levarás, || e poucos te olharão maravilhados ${ }^{79}$.

E mais adiante, [digo] quantos benefícios advirão aos que trataram correctamente a terra, o que deve ser considerado uma previsão utilíssima para a vida [humana].

7. LICINO - Essas tuas palavras, ó admirável Hesíodo, são mesmo de pastor ${ }^{80}$, e tu próprio pareces comprovar a verdade da inspiração das Musas, pois não és capaz de justificar os teus versos. Mas não é essa a adivinhação que nós esperávamos da tua parte e da parte das Musas, porquanto, nessa matéria, os lavradores são muito melhores adivinhos que vós ${ }^{81} \mathrm{e}$ mais capazes de nos fornecer previsóes nessa matéria, ou seja, que, se a divindade tiver mandado chuva, as searas serão florescentes; se sobrevier uma seca e os campos estiverem sequiosos, náo haverá forma de evitar que à sede dos campos se siga a fome; que não se deve lavrar em pleno Verão, pois, com toda a

${ }^{79}$ Hesíodo, Trabalhos e Dias, 482, mas é preciso ter presentes (como Licino certamente tinha) os vv. 479-481, que dizem, resumidamente, que, se lavrares a terra no solstício de Inverno, colherás poucas e raquíticas espigas, e então... (v. 482).

80 "de pastor"... entenda-se: e não de lavrador! /v. a seguir).

81 "vós", i. é, "tu e as Musas", ou "vós, os pastores”... 
evidência, não haveria vantagem em espalhar a semente; nem ceifar a espiga ainda verde, caso em que se acharia um grão oco. Também não necessitas da adivinhação para dizeres que, se não esconderes as sementes e se um criado, munido de uma enxada, não as cobrir de terra, as aves abater-se-ão sobre elas e devorarão antecipadamente toda a esperança do Verão.

8. Realmente, ao dizer tais coisas, [que não passam de] conselhos e avisos, uma pessoa não erraria, mas isso parece-me estar muito longe da adivinhação, cuja função consiste em prever factos não evidentes e de maneira nenhuma visíveis, como por exemplo predizer a Minos que o seu filho ${ }^{82}$ se afogaria num pote de mel, ou prevenir os Aqueus contra a cólera de Apolo, bem como o motivo por que Ílion seria tomada no décimo ano. Sim, isso é que é adivinhação. Ora, se nesta [arte] se incluírem coisas como as que tu dizes, eu próprio não tardaria a ser considerado adivinho, pois predirei e profetizarei - e isto sem Castália, sem loureiro e sem a trípode délfica - que, se um indivíduo caminhar nu e ao frio, e ainda por cima se a divindade mandar chuva e granizo, esse fulano apanhará um resfriado, e não pequeno, e depois disso - coisa ainda mais previsível que essa —, seguir-se-á, naturalmente, uma [forte] febre... E muitas outras previsóes deste género, que seria ridículo mencionar.

9. Portanto, deixa-te dessas justificaçôes e dessas adivinhações. Aquilo, porém, que disseste no início talvez seja de aceitar, ou seja, que náo sabias nada do que estavas a dizer, mas que uma espécie de inspiraçáo divina é que gerava os teus versos, ela própria não muito clara, já que cumpria uma parte das promessas, mas deixava a outra incumprida.

${ }^{82}$ Trata-se de Glauco, que, ainda menino, ao perseguir um rato, se afogou num pote de mel. Glauco acabou por ser ressuscitado pelo adivinho Poliido, que o esfregou com uma erva mágica... 
O Cita ou O "Próxeno" 
(Página deixada propositadamente em branco) 


\section{INTRODUÇẤO}

A adaptação ao port. do título alternativo, gr. próxenos

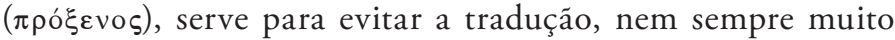
aproximada, por "cônsul" ou "hospedeiro".

Denominava-se "próxeno” o cidadão de um Estado, que aí representava os interesses de um Estado estrangeiro ou de um cidadáo estrangeiro de passagem ou residente no Estado do "próxeno". Este também tinha por função receber os embaixadores do Estado que ele representava. Como se vê, ao contrário do moderno cônsul, o "próxeno" funcionava dentro do seu próprio país, proposto por um país estrangeiro, naturalmente de acordo com o interessado.

No entanto, o vocábulo também se aplicava ao indivíduo que, a título meramente individual, recebia em sua casa um estrangeiro, com o qual se travara de amizade aquando de uma visita ou estada noutro país. Os usos e costumes davam grande valor à hospitalidade, pelo que o hospedeiro considerava o hóspede um ser sagrado, tanto mais que, não raro, as situaçóes se invertiam.

Este discurso de apresentação, tal como o intitulado Harmónides, foi pronunciado numa cidade da Macedónia, certamente diferente e dirigido a duas outras personagens. Vê-se que Luciano, no início da sua carreira de orador, advogado e sofista, pretende "promover-se" junto de patronos poderosos.

Neste discurso, usando a mesma técnica que em outros, invoca uma história antiga bem conhecida, que acaba por aplicar ao seu próprio caso. A história situa-se no tempo de Sólon, já de avançada idade, e tem como personagem interessante para o caso um cidadáo da Cítia, Tóxaris, o qual, à semelhança do seu nobre compatriota Anacársis, vem a Atenas, no desejo de contactar com a cultura helénica e os seus mais ilustres representantes. Então Anacársis apresenta-o a Sólon, a personagem mais sábia e de maior prestígio em Atenas. "Se conseguires tê-lo como amigo e conheceres o género de homem que ele é, então acredita que possuis ${ }^{83}$ em ti mesmo

${ }^{83}$ A tradução "corrente é: "considera que ele possui em si toda a Grécia e conhece a súmula das suas virtudes". Considero, porém, que o sujeito de possuir,

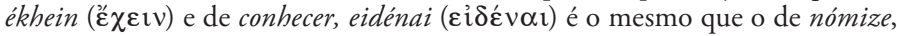
pois caso contrário um sujeito diferente teria de estar expresso; naturalmente,

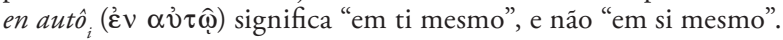


toda a Grécia e conheces a essência das suas virtudes. Assim sendo, não há nada mais importante e melhor que eu pudesse oferecer-te, do que recomendar-te a esse homem."(\$5).

A história de Tóxaris serve a Luciano para revelar que também ele, ao chegar a uma importante cidade da Macedónia (certamente diferente da referida em Harmónides), sentiu a necessidade de obter apoio de alguma personagem importante. Todos aqueles junto dos quais se informou lhe falaram de dois ilustríssimos cidadãos, pai e filho, cuja protecção lhe valeria a fama e a estima de toda a cidade. Nos $\$ \$ 10-11$, Luciano póe na boca dos seus informadores um elogio descaradamente servil dos seus dois ansiados patronos.

Por isso, não convém ficar parado, mas "há que mover todos os cabos ${ }^{84}$, tudo fazer e dizer, para que tais homens se tornem meus amigos. Sim, se tal coisa acontecer, tudo ficará sereno, a navegação com vento de cauda, o mar com lisas ondas e o porto muito perto" (\$11, fim).

84 "mover todos os cabos" (do navio), para desfraldar as velas e zarpar a toda a velocidade. 


\section{O Cita ou O "Próxeno"}

1. Não foi Anacársis o primeiro que veio da Cítia para Atenas, [movido] pelo desejo de conhecer a cultura helénica, mas também, antes dele, Tóxaris, homem sábio e apreciador das coisas belas, e também desejoso de conhecer os mais nobres usos e costumes, ele que, na sua pátria, não era de família real nem da classe dos "pilóforos" 85 , mas um dos muitos citas, da classe popular, que entre eles são designados por octápodes ${ }^{86}$, ou seja, donos de dois bois e de uma única carroça. Este Tóxaris nunca mais regressou à Cítia, mas até morreu em Atenas, e, passado não muito tempo, os Atenienses consideraram-no "heróí" 87 e oferecem sacrifícios ao "Médico Estrangeiro", cognome que adquiriu quando foi feito "herói”. Talvez não seja mau contar a razão do cognome e por que motivo foi incluído na categoria dos "heróis" e tido por um dos filhos de Asclépio, isto para que fiqueis sabendo que não é um costume exclusivamente nacional dos Citas imortalizar [um humano] e enviá-lo para Zamólxis ${ }^{88}$, pois também entre os Atenienses é possível divinizar citas em terra grega.

2. Aquando da grande peste ${ }^{89}$, a esposa de Arquíteles, membro do Areópago, julgou que lhe apareceu [em sonho] o cita [Tóxaris], que lhe ordenou que dissesse aos Atenienses que eles poriam termo à peste, se regassem as ruas com grande quantidade de vinho. Tendo os Atenienses assim procedido repetidamente — pois náo se descuidaram do [conselho] que haviam ouvido - , deixaram de sofrer de peste, quer porque

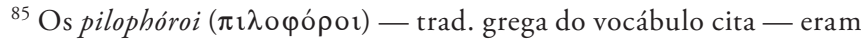
nobres, que se distinguiam por usarem uma espécie de barrete de feltro.

${ }^{86}$ A designação grega — trad. grega do vocábulo cita — oktápodes

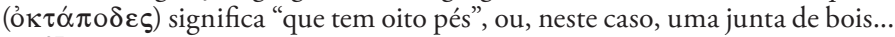

87 "heróí" era, para os Gregos, um semideus, ou seja, em que um dos progenitores era divino, e o outro humano. Neste caso, Tóxaris passava por ser um dos filhos de Asclépio, o qual, por sua vez era filho de Apolo e de uma mortal. Era, pois, uma espécie de "herói” em "segundo grau"!

88 "Zamólxis" (ou Zálmoxis) era o deus único dos Citas. A expressão enviar alguém para Zamólxis significa, eufemisticamente, não só "entregar a alma ao criador" (releve-se a expressáo!), mas, muito mais que isso, "divinizar um ser humano"...

${ }^{89}$ Referência à peste de 430-429 a.C., em Atenas, magnificamente descrita por Tucídides. 
o vinho, com o seu odor, tivesse extinguido os maus vapores, quer porque o "herói" Tóxaris, por saber mais qualquer coisa, como médico que era, o aconselhara. Actualmente, ainda lhe são pagos os honorários pela cura, sob a forma de um cavalo branco sacrificado junto do seu túmulo, no sítio de onde Diménete ${ }^{90}$ indicou que ele partiu para lhe indicar aquele procedimento sobre o vinho. E realmente foi ali encontrado o túmulo de Tóxaris, reconhecido tanto pela inscrição (apesar de não estar toda legível), como, sobretudo, pelo facto de na estela [funerária] estar gravada a figura de um cita, com um arco esticado na mão esquerda, e na direita, segundo me pareceu, um rolo [de papiro] ${ }^{91}$. Mesmo actualmente, ainda poderás ver cerca de metade da figura, o arco por completo e o rolo [de papiro]. A parte superior da estela e o rosto, já o tempo em parte os desgastou. Situa-se não muito longe do Dípilo, à esquerda de quem se dirige para a Academia. O túmulo não é muito grande, e a estela jaz por terra; mesmo assim, está permanentemente coberta de coroas, e diz-se que algumas pessoas atingidas por febre têm visto o fim do seu mal, graças a Tóxaris, coisa que, por Zeus!, não deixa de ser credível para quem outrora curou toda uma cidade.

3. Mas o motivo por que recordei a sua história deve-se ao facto de Tóxaris ainda estar vivo, quando Anacársis, acabado de desembarcar, subia do Pireu [para Atenas], um estrangeiro e um bárbaro, não pouco perturbado da mente com tudo aquilo, pois estranhava tudo, assustado com tanto barulho, sem saber o que fazer consigo próprio. Realmente, apercebia-se de que estava a ser motivo de troça por parte dos que o viam com aquele seu vestuário, e além disso náo encontrava ninguém que falasse a sua língua... enfim, já estava arrependido de ter feito aquela viagem, pelo que decidiu, mal tivesse visitado Atenas, voltar imediatamente para trás, meter-se no barco e navegar novamente direito ao Bósforo, de onde o caminho até à sua pátria, na Cítia, não era muito longo. Estava Anacársis com estes pensamentos, quando um génio benfazejo, [que] na

${ }^{90}$ Diménete é a esposa de Arquíteles, mencionada no início deste parágrafo.

${ }^{91}$ Parece-me difícil conjugar a imagem de um arco esticado, (acusat.)

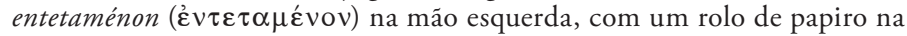
mão direita, onde esperaríamos, antes, uma flecha. Em todo o caso, Luciano (que analisou ocularmente a estela) não é assertivo; "segundo me pareceu"... 
realidade [era] Tóxaris, veio ao seu encontro, já no Ceramico ${ }^{92}$. Imediatamente lhe chamou a atenção a veste, que era a da sua pátria; em seguida, náo teve dificuldade em reconhecer Anacársis, pois este pertencia a uma família notabilíssima e das primeiras entre os Citas. Anacársis, pelo contrário, como é que poderia reconhecer aquele seu compatriota, assim vestido à grego, de barba rapada, sem cinturão, sem arma, tão tagarela, enfim, um de entre os nascidos na Ática, a tal ponto tinha sido modificado pelo tempo?!

4. Então Tóxaris, dirigindo-se-lhe em língua cita, disse: "Por acaso não és tu Anacársis, filho de Dáucetas?" Anacársis até chorou de prazer, por ter encontrado uma pessoa da mesma língua e ao tomar conhecimento de quem ele era entre os Cítios. E perguntou-lhe: "Tu, ó estrangeiro, como é que nos" conheces? Eu também sou — disse ele — da vossa terra, o meu nome é Tóxaris, não pertenço à classe dos ilustres, e por isso não poderia ser reconhecido por ti." E retorquiu Anacársis: "Por acaso não és tu aquele Tóxaris, a respeito de quem eu ouvi dizer que um certo Tóxaris, apaixonado pela Grécia, deixou na Citia a sua esposa e os seus filhos menores e veio para Atenas, e vive actualmente aqui, honrado pelos mais ilustres [cidadãos]?" "Sim — respondeu Tóxaris _-, sou eu mesmo... se é que ainda se fala de mim no vosso país." "Pois então — disse Anacársis —, fica sabendo que eu me tornei teu discípulo e teu imitador na paixão que tu sentistes de visitar a Grécia, e foi com esse objectivo que eu emigrei. Cheguei aqui, depois de passar por mil vicissitudes nos países que ficam pelo meio, e, caso náo te tivesse encontrado, já tinha decidido voltar para trás antes do pôr do sol e meter-me no barco... a tal ponto fiquei perturbado ao ver tanta coisa estranha e desconhecida... Mas, por Acinaces ${ }^{94}$ e Zamólxis!, os nossos deuses nacionais, tu, ó Tóxaris, toma conta de mim, sê meu guia e mostra-me as coisas mais belas de Atenas, e depois também no resto da Grécia, como as suas melhores leis, os seus mais excelentes

92 O Ceramico, "Bairro dos Oleiros", ficava a Noroeste da Acrópole, parte fora da muralha, que era usada como cemitério, enquanto na parte de dentro ficava a ágora.

93 "nos", plural majestático.

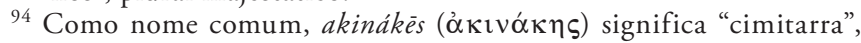
arma divinizada pelos Citas, e portanto, em port., com maiúscula: pela Cimitarra! 
homens, os seus usos e costumes, as suas assembleias festivas, o seu modo de vida, a sua constituição, enfim, aquelas coisas pelas quais tu e eu empreendemos esta viagem. Não me deixes regressar sem ter visto essas coisas."

5. "O que acabas de dizer — disse Tóxaris —, ou seja, vir até à porta [de entrada] e logo partir, revela pouquissima paixão. Mas anima-te, pois náo partirás, como dizes, nem esta cidade te deixaria [partir] com essa facilidade. Ela não possui assim tão poucos encantos para os estrangeiros, mas cativar-te-á completamente, a ponto de já nem te lembrares da tua esposa nem dos teus filhos... se é que já tens alguns. Pois vou mostrar-te como poderás ver toda a cidade de Atenas, ou melhor, toda a Grécia $e$ as suas belezas... Existe aqui um homem sábio ${ }^{95}$, natural desta cidade, mas que andou muito lá por fora, pela Ásia e pelo Egipto, e que contactou com os homens mais eminentes, e que náo é da classe dos ricos, mas sim bastante pobre. Verás um velho vestido à maneira do povo. No entanto, devido à sua sabedoria e às suas restantes qualidades, [os Atenienses] estimam-no muitissimo, a tal ponto, que o utilizam como legislador da sua Constituição $e$ desejam viver segundo as suas leis. Se conseguires tê-lo como amigo e conheceres o género de homem que ele é, então acredita que possuis ${ }^{6}$ em ti mesmo toda a Grécia e conheces a essência das suas virtudes. Assim sendo, não há nada mais importante e melhor que eu pudesse oferecer-te, do que recomendar-te a esse homem."

6. "Nesse caso, ó Tóxaris - disse Anacársis —, não percamos tempo, mas leva-me contigo e conduz-me à sua presença... Mas receio uma coisa, que ele seja de acesso difícil e não dê importância à tua recomendação em meu favor." "Longe vá o agoiro! — disse Tóxaris - Estou convicto de que ele até ficará bastante contente por eu lhe proporcionar a oportunidade de fazer bem a um estrangeiro. Segue-me! Sim, ficarás a conhecer o seu respeito por

${ }^{95}$ Luciano só nos \$\$6-7 é que identifica esse homem. Por isso, também não o faço neste momento.

${ }^{96}$ A tradução "corrente é: "considera que ele possui em si toda a Grécia e conhece a súmula das suas virtudes”. Considero, porém, que o sujeito de

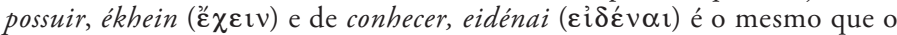
de nómize, pois caso contrário um sujeito diferente teria de estar expresso; naturalmente, en autô ${ }_{i}(\mathcal{\varepsilon} v \alpha \hat{\tau} \tau \hat{\omega})$ significa "em ti mesmo", e não "em si mesmo". 
[Zeus] 'Xénio ${ }^{x 7}$, bem como a sua afabilidade e a sua bondade... Mas... eis que, por graça divina, ele mesmo vem ao nosso encontro, aquele muito pensativo e a falar consigo mesmo". E dirigindo-se a Sólon, Tóxaris disse: "Trago-te aqui este importante 'presente, um estrangeiro que precisa da tua amizade...

7. "É um cita da nossa classe dos nobres, e mesmo assim deixou tudo o que lá tinha, para vir conviver convosco e ver as belíssimas coisas da Grécia. Então eu achei que este era o caminho mais curto para ele aprender facilmente tudo isso e para se tornar conhecido dos homens mais ilustres. Ora, se eu bem conheço Sólon, tu assim procederás, recebê-lo-ás como teu hóspede e farás dele um autêntico cidadão da Grécia... E ó Anacársis, tal como te disse um pouco atrás, se tiveres visto Sólon, terás visto tudo. 'Isto' é Atenas, 'isto' é a Grécia, e já não és estrangeiro, e todos te conhecem, todos te amam. Tal é o enorme valor inerente a este ancião. Ao conviveres com ele, esquecer-te-ás da tua vida lá na Cítia. Aqui tens o prémio da tua emigração, a realização da tua paixäo. Este homem é o modelo da Helenismo, o paradigma da Filosofia ática. Convence-te, pois, de como és afortunado por conviver com Sólon e gozares da sua amizade."

8. Seria longo de contar a maneira como Sólon se congratulou com este 'presente', as palavras que disse, como passaram a conviver, um deles, Sólon, instruindo e ensinando Anacársis nas mais belas matérias, tornando-o querido de todos e apresentando-o aos mais excelentes de entre os Gregos, enfim, cuidando por todos os meios de que ele passasse na Grécia a mais agradável das estadas, enquanto o outro, Anacársis, maravilhado com a sabedoria de Sólon, não se afastava dele, por sua vontade, nem sequer um instante. Assim, tal como Tóxaris lhe havia prometido, Anacársis, por acção de um único homem, Sólon, ficou a conhecer tudo num instante e, através dele, tornou-se conhecido e [muito] estimado de todos. $\mathrm{Na}$ verdade, um elogio na boca de Sólon não era coisa de somenos importância, pois as pessoas confiavam nele como legislador, estimavam aqueles a quem Sólon dava valor e acreditavam que se tratava de homens excelentes. Por fim, a acreditarmos em Teóxeno ${ }^{98}$,

97 'Xénio', um dos epítetos de Zeus como deus protector dos xénoi

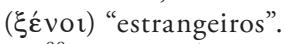

98 Teóxeno, historiador, hoje desconhecido. 
que historiou este facto a seu respeito, Anacársis, uma vez feito cidadão [ateniense], foi o único de entre os bárbaros iniciado nos mistérios. E não teria, julgo eu, nunca mais regressado à Cítia, se Sólon não tivesse morrido.

9. Quereis ${ }^{99}$ que eu ponha imediatamente termo a esta história, para que ela não ande por aí sem cabeça? Sim, já é tempo de revelar por que motivo é que Anacársis, lá da Cítia, e Tóxaris, vieram, por minha mão, até à Macedónia dos nossos dias e trouxeram consigo, de Atenas, o velho Sólon. Pois passa-se comigo o mesmo que aconteceu a Anacársis — mas, pelas Cárites!, não vos irriteis por esta minha imagem, ao comparar-me com uma figura régia. De facto, este também era bárbaro, e não poderias dizer que nós, os sírios, somos menos que os citas. Mas eu não ponho a minha situação em pé de igualdade com a condição régia, mas num outro plano. $\mathrm{Na}$ verdade, quando pela primeira vez me desloquei à vossa cidade, fiquei logo deslumbrado, ao ver a sua grandeza, a sua beleza, o grande número dos seus habitantes, enfim, o seu poder e toda a sua magnificência. Fiquei durante muito tempo atónito com tudo isso e não cabia em mim de admiraçáo, sentindo o mesmo que o famoso jovem ${ }^{100}$ ilhéu no palácio de Menelau. Também eu devia ficar com esse sentimento, ao ver uma cidade cheia de tamanha prosperidade e, segundo o célebre poeta ${ }^{101}$,

De todos os bens florida, || em que brilha uma cidade.

10. Nesta disposição de espírito, ia reflectindo sobre o que haveria de fazer. Desde há muito que tinha decidido apresentar-vos uma amostra das minhas obras. Mas a quem as apresentaria, se percorresse em silêncio esta grande cidade? Então procurei saber — não vos omitirei a verdade - quem eram os notáveis, aqueles a quem uma pessoa devia dirigir-se e escolher

${ }^{99}$ Luciano, depois de citar longamente a história de Anacársis, dirige-se finalmente à assistência que tinha acorrido a ouvi-lo. A cena passa-se numa das cidades da Macedónia, provavelmente no início da carreira de Luciano, jovem acabado de formar e desejoso de fama e glória... o que exige, geralmente, um grande esforço de "promoção".

${ }_{100}$ Referência a Telémaco, que foi a Esparta, esperando saber aí notícias de seu pai, Ulisses.

101 Poeta desconhecido, certamente um trágico, pois o verso é um trímetro jâmbico. 
como protectores, para que fossem meus apoiantes em tudo isso. Ora, nesta cidade surgiram-me, não apenas um, como, no caso de Anacársis, Tóxaris, e este mesmo um bárbaro, mas muitos, ou melhor, todos me diziam a mesma coisa, só que por palavras diferentes: "Ó estrangeiro, existem nesta cidade muitos homens honestos e de grande valor, e não encontrarias noutra qualquer parte tantos homens bons; No entanto, temos sobretudo dois homens que sobressaem de entre todos, eminentissimos quer pelo nascimento, quer pelo mérito, e que, pela sua cultura e força oratória, bem poderias comparar aos 'dez [oradores] áticos' 102. $A$ afeição do povo [para com eles] é uma autêntica paixão, e só se faz aquilo que eles querem, pois eles querem o que é o melhor para a cidade. Quanto à sua bondade, à sua amabilidade com os estrangeiros, ao seu comportamento irrepreensivel no mais alto grau, ao carácter respeitoso dos seus bons sentimentos, à sua afabilidade e à fácil acessibilidade, tu próprio poderás contar a outros, pouco depois de conviveres com eles...

11. "E para que a tua admiração seja ainda maior, ambos são da mesma familia, filho e pai, um deles, o pai, imagina um Sólon, um Péricles, um Aristides, e o outro, o filho, cativar-te-á, só de olhares para ele, tão alto ele é e tão formoso, de uma compleição física bem varonil. Basta ele soltar uma palavra, e deixar-te-á preso pelos ouvidos, tal é o poder de atracção que o jovem tem através da lingua. Toda a cidade o escuta boquiaberta, quando ele avança para discursar, tal qual se diz que os Atenienses desse tempo sentiam em relação ao filho de Clinias, só com a diferença de que os Atenienses, passado não muito tempo, se arrependeram da paixão que tinham por Alcibiades; mas no caso do outro, a cidade não só o ama, mas já o considera digno de veneração... numa palavra, este homem é para nós um bem público único $e$ de grande utilidade para todos nós. Portanto, se ele e o seu pai te acolherem e te fizerem seu amigo, tens toda a cidade contigo, e basta que eles te estendam a mão, apenas isso, e os teus interesses não sofrerão contestação."

Foi isto, por Zeus! (se é que posso fazer tal juramento), o que as pessoas diziam, e realmente, pela minha experiência

${ }^{102}$ Os "dez [oradores] áticos" ou a "década ática": lista "canónica", algo arbitrária, dos dez oradores áticos considerados exemplares e, por isso, objecto de estudo escolar: Antifonte, Andócides, Lísias, Isócrates, Iseu, Licurgo, Ésquines, Hiperides, Demóstenes e Dinarco. 
até agora, creio que só disseram uma pequeníssima parte da realidade. Como diz o poeta de $\mathrm{Ceos}^{103}$,

Não convém ficar sentado, || nem remeter pra mais tarde,

mas, pelo contrário, há que mover todos os $\operatorname{cabos}^{104}$, tudo fazer e dizer, para que tais homens se tornem meus amigos. Sim, se tal coisa acontecer, tudo ficará sereno, a navegaçáo com vento de cauda, o mar com lisas ondas e o porto muito perto.

${ }^{103}$ Baquílides; v. Edmonds, Lyra Graeca, III, pp. 123-124. A citação não é exacta, embora resitando inteiramente o sentido.

104 "mover todos os cabos" (do navio), para desfraldar as velas e zarpar a toda a velocidade. 
“És um Prometeu... nas Palavras" 
(Página deixada propositadamente em branco) 


\section{INTRODUÇẤO}

Alguém, provavelmente na sequência de uma leitura ou declamação de Luciano perante uma audiência, parece ter comentado, dizendo directamente ao orador: "Tu és um Prometeu... nas palavras (reticências minhas!), ou seja, não propriamente nas obras, como o Prometeu mitológico, mas nos escritos de Luciano, especialmente, como se verá mais adiante, nos Diálogos.

Ora, o comentário ganha o aspecto de uma subtileza de intelectual, que logo se transforma, na mente de Luciano, numa espécie de adivinha ou de enigma, que - imagino eu, não é citação! - o levaria a perguntar a si mesmo: Por que raio é que o fulano me chamou (ou me comparou a) Prometeu?

A uma subtileza erudita Luciano responde com uma erudita análise das respostas possíveis: Pelo facto de os escritos de Luciano serem táo frágeis como as obras de barro de Prometeu (nomeadamente o ser humano)? Pelo estilo artificioso, assimilável ao espírito artificioso do grande Titâ?... Além de outras razôes, Luciano lembra a sua grande "invenção", que consiste em juntar num só género o Diálogo e a Comédia, ambos isoladamente muito belos, mas cuja mistura pode resultar num produto monstruoso, como o homem de duas cores, o hipocentauro, etc.

Enfim, o comentário do outro veio mesmo a propósito, para que Luciano pudesse expandir a sua imaginaçáo e produzir, no escritor compulsivo (vê-se!) mais umas páginas... 
(Página deixada propositadamente em branco) 


\section{"És um Prometeu... nas Palavras"}

1. Dizes tu então que eu sou um Prometeu? Ora, meu caro, se dizes tal coisa por as minhas obras também serem de barro, reconheço-me na comparação e afirmo que sou semelhante a ele, nem desdenho de que me chamem oleiro, mesmo que o meu barro seja de pior qualidade, como o que vem de uma encruzilhada e que por pouco que náo é lama. Mas se, pelo contrário, é no intuito de elogiar ao máximo as minhas palavras, alegadamente artificiosas, que tu mencionas o mais sábio dos Titấs, vê lá não vá alguém dizer que está contida nesse elogio uma certa ironia e uma piada de tipo ático... Mas onde está o meu estilo artificioso? Que sabedoria transbordante é essa, ou que prudência... prometaica ${ }^{105}$ haverá nos meus escritos? A mim, já me basta que não te pareçam demasiado "térreos" nem completamente dignos do Cáucaso. Em todo o caso, com quanto maior justiça vós poderíeis comparar a Prometeu todos quantos, em processos judiciais, vós admirais e que, esses sim, travam batalhas autênticas ${ }^{106}$. Realmente, as vossas obras são verdadeiramente vivas e animadas, e, por Zeus!, o seu calor é bem... fogoso. Ora, essa qualidade talvez provenha de Prometeu, com uma única diferença, a saber, que vós não "amassais" [os vossos discursos] com barro, mas, pelo contrário, para a maior parte de vós, as vossas obras são amassadas em... ouro.

2. Nós, porém, que nos apresentamos diante das massas e lhes oferecemos estas nossos declamaçóes, mostramos apenas umas imagens, e tudo isso, conforme disse um pouco atrás, feito de barro, pois a nossa "plástica" é a mesma que a dos fazedores de bonecos. Aliás, [essas imagens] não possuem nem movimento, nem qualquer aparência de alma, pois a coisa não passa de um entretenimento e de uma brincadeira. Assim sendo, ocorre-me pensar se tu náo dizes que eu sou um Prometeu, no

105 "prudência... prometaica": o gr. tem só o subst. promếtheia $(\pi \rho \rho \mu \eta ́ \theta \varepsilon \imath \alpha)$, que, obviamente, sugere (aliás etimologicamente!) o nome de Prometeu. Também poderíamos considerar antes uma emenda (de minha responsabilidade!),

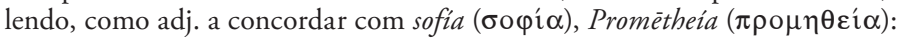
“... uma sabedoria transbordante e... prometaica".

106 "batalhas autênticas" opóe-se claramente às declamationes, mera oratória de aparato. 
mesmo sentido em o comediógrafo falava de Cléon. Deste se dizia, como sabes, que

Cléon é um Prometeu... || mas depois do acontecido ${ }^{107}$.

Os próprios Atenienses chamavam "Prometeus" aos que faziam potes ou fornos, e a todos quantos trabalhavam com o barro, aludindo por troça ao barro, ou mesmo, julgo eu, à cozedura dos objectos no fogo. Entáo, se Prometeu quer dizer isso, foi muito certeiramente que tu disparaste o arco no sentido da mordacidade ática da chacota, pois, na verdade, as nossas ${ }^{108}$ obras também são muito frágeis, como os potes dos oleiros, e qualquer pessoa, atirando-lhes uma pequena pedra, os quebraria a todos.

3. No entanto, alguém, para me consolar, poderia dizer que "não foi nesse sentido que o outro te comparou a Prometeu, mas, pelo contrário, pretendeu elogiar a tua originalidade e o facto de não imitares nenhum modelo, tal como Prometeu, o qual, quando ainda não existiam seres humanos, imaginou a maneira de os modelar, formando tais seres vivos e conformando-os de modo que tivessem movimentos e fossem agradáveis de ver. Foi ele o arquitecto de tudo isso, embora Atena também o tenha ajudado, soprando para dentro do barro e fazendo com que aquelas criaturas tivessem vida".

Era isso o que essa pessoa poderia dizer, interpretando a minha expressão no sentido mais favorável, e talvez fosse essa a intenção das tuas palavras. A mim, porém, não me basta ser considerado original e que ninguém possa referir uma criação mais antiga, da qual esta minha seja derivada. Se, porém, ela não se mostrasse prazenteira, eu, fica tu sabendo, envergonhar-me-ia dela, espezinhá-la-ia e destruí-la-ia, porquanto, para mim, a originalidade de nada valeria para evitar que uma coisa, sendo feia, fosse aniquilada. E se porventura eu não pensasse desta maneira, creio que seria digno de ser despedaçado por dezasseis

107 Verso atribuído, quer a Aristófanes, quer ao seu contemporânei Êupolis. É preciso lembrar que o nome Prometeu significa "previdente"... mas, segundo o cómico... depois dos acontecimentos, ou seja, mais parecido com o irmáo de Prometeu, Epimeteu, "que só pensa depois dos acontecimentos".

108 "nossas", plural majestático, ou plural generalizante, referido a todso os "declamantes"... 
abutres, pelo facto de não perceber que as coisas ficam ainda mais feias, quando se lhes associa a bizarria.

4. Por exemplo, Ptolemeu, filho de Lagos, trouxe para o Egipto duas novidades, uma camela de Bactriana, completamente negra, e um homem com duas cores, distribuídas por igual, em que um lado era retintamente negro, e o outro extremamente branco. Então, tendo reunido os egípcios no teatro, apresentou-lhes muitas outras atracçóes e, por fim, estas duas: a camela e o homem semibranco. Cuidava ele que provocaria grande espanto com esse espectáculo. As pessoas, porém, ficaram apavoradas com a camela, e pouco faltou para fugirem em debandada, apesar de o animal estar todo enfeitado de ouro, ter uma manta de púrpura e um freio cravejado de pedras preciosas, um tesouro digno de um Dario, de um Cambises ou de um Ciro. Quanto ao homem, as pessoas, na sua maioria, riam, e outros ficaram horrorizados com a monstruosidade. Entấo Ptolemeu, vendo que não obtinha aplauso da parte das pessoas e que a novidade não era admirada pelos egípcios, mas que, em vez da novidade, eles apreciavam antes a regularidade e a justa proporção, mandou retirar essas [figuras], que já não apreciava como anteriormente, mas, pelo contrário, a camela morreu por falta de cuidados, e quanto ao homem de dupla cor, ofereceu-o ao tocador de flauta Téspis, que tinha tocado muito bem durante uma jantarada.

5. Receio que a minha obra seja como a camela foi para os Egípcios, e que as pessoas admirem antes o seu "freio" e a manta de púrpura, pois o facto de estarem reunidos dois géneros belíssimos - o Diálogo e a Comédia - não basta para [obter] a justa perfeição, se a mistura não for harmoniosa e nas devidas proporçôes. Realmente, é possível que de duas coisas belas resulte uma síntese bizarra, como é o caso, aqui à mão, do hipocentauro. De facto, não se poderá dizer que este é um animal encantador, mas sim violentíssimo, se devemos acreditar nos pintores, que nos mostram as suas bebedeiras desmedidas e as chacinas [a que se entregam]. É o quê?! Então náo pode, de duas coisas excelentes, resultar uma síntese bem equilibrada, como do vinho e do mel, de que resulta um conjunto agradabilíssimo? Eu acho que sim. Em todo o caso, no que respeita às minhas obras, não posso garantir que assim 
seja, mas, pelo contrário, receio que a mistura tenha ao mesmo tempo destruído a beleza de cada um dos géneros ${ }^{109}$.

6. Na verdade, o Diálogo e a Comédia não eram, logo de início, muito íntimos e muito amigos, dado que aquele fazia os seus debates dentro de casa e metido consigo mesmo, ou, por Zeus!, em passeatas com poucas pessoas, ao passo que esta se entregava a Dioniso, convivia com ele no teatro, brincava juntamente com ele, ria, troçava, algumas vezes marchava ritmicamente ao som da flauta, mas evoluía geralmente ao ritmo dos versos anapésticos ${ }^{110}$, e até troçava dos amigos do Diálogo, chamando-lhes "meditativos"111 e "dissertantes nas alturas” e coisas do género, e tinha como único objectivo ridicularizá-los e despejar sobre eles a liberdade dionisíaca, mostrando-os, ora a caminhar nos ares e a conviver com as nuvens, ora a medir os saltos de uma pulga, ora, alegadamente a "subtilizar" sobre fenómenos celestes. O Diálogo, porém, tornava os debates mais graves, filosofando acerca da natureza e da virtude. Deste modo, em termos musicais, havia entre ambos a diferença de duas oitavas, desde o mais agudo ao mais grave. Apesar disso, porém, nós atrevemo-nos ${ }^{112}$ a juntá-los, tal como eram, um com o outro e a harmonizá-los, apesar de eles não serem lá muito “obedientes” nem fáceis de suportar a convivência.

7. Receio, pois, dar a ideia de ter feito algo parecido com o teu Prometeu ${ }^{113}$, ao misturar o feminino ${ }^{114}$ com o masculino e incorrer, por isso, num processo judicial, ou antes, receio parecer-me com Prometeu num outro aspecto, ou seja, talvez por enganar os ouvintes, dando-lhes "ossos" escondidos sob [uma

${ }^{109}$ Recorde-se que Luciano se refere à junção do Diálogo com a Comédia: v. a seguir.

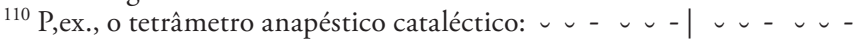
$\left|\smile \_-\_--\right| \smile--\mid$. Notar que as duas breves podiam ser substituídas por uma longa.

111 “meditativos"... ... fenómenos celestes": Alusão clara às Nuvens de Aristófanes.

112 "nós atrevemo-nos", plural majestático.

113 “o teu Prometeu”, náo o Prometeu da mitologia, mas o da frase dita por certa pessoa, a qual dá o título a este opúsculo.

${ }^{114} \mathrm{O}$ feminino é a Comédia; o masculino é $o$ Diálogo. 
camada de] "gordura"115 — troça cómica sob a capa da gravidade filosófica. Quanto à questão do furto ${ }^{116}$ — e Prometeu também é um deus do furto - deixa isso para lá, pois é a única coisa que não poderias dizer que existe nas minhas obras. Sim, a quem é que nós ${ }^{117}$ furtamos?... A menos, talvez, que alguém, sem eu saber, tenha composto esses tais "hipocampos"118 e "hircocervos". Mas então que fazer? $\mathrm{Na}$ verdade, há que persistir naquilo por que previamente optei, porquanto mudar de projecto é próprio de Epimeteu ${ }^{119}$, não de Prometeu.

115 Trata-se de uma das maldades que Prometeu cometeu contra Zeus: Num sacrifício solene, dividiu o boi em duas partes: uma com a boa carne, mas coberta de pele, e a outra de ossos, mas envolvidos em gordura. Já se vê (?) que Zeus, enganado pelas aparências, escolheu a parte pior. Como castigo, Zeus retirou o fogo aos homens... mas Prometeu encarregou-se de o surripiar, nas imediaçóes do Sol.

116 "furto", do ponto de vista da obra literária de Luciano, chamar-se-ia plágio.

117 "nós": mais uma vez, plural majestático.

118 "hipocampos", monstro marinho, com corpo de cavalo e cauda de peixe encurvada (também, mas não aqui!) nome científico dado ao cavalo-marinho; os "hircocervos" eram animais monstruosos, metade bode e metade cervo.

${ }^{119}$ Enquanto Prometeu é "aquele que pensa antes", "aquele que prevê", o "previdente", o "prudente", seu irmão Epimeteu é "aquele que só pensa depois", o "imprevidente". 
(Página deixada propositadamente em branco) 
Elogio de Demóstenes 
(Página deixada propositadamente em branco) 


\section{INTRODUÇẤO}

Para a crítica moderna em geral, esta obra não é da autoria de Luciano. Para M. D. Macleod ("Loeb”, VIII, p. 237), este Elogio de Demóstenes apresenta falta de inspiração, grego de inferior qualidade e o facto de evitar o hiato. Em meu entender, não vejo na obra uma falta de inspiração assim tão acentuada. Quanto à fraca qualidade do grego, poderíamos, de facto, esperar algo mais de um escritor como Luciano, mas não excluo a possibilidade de se tratar de uma obra de juventude, em que o sírio Luciano ainda não possui as subtilezas da língua grega e fica mesmo "deslumbrado" com vocabulário poético, cujo uso, em situaçóes claramente prosaicas, fica bastante ridículo. Aliás, o "ático" Luciano nunca se livrou completamente de um certo hibridismo dialectal e literário, que chega a incluir, aqui e acolá, elementos da linguagem corrente. Quanto ao facto de o autor evitar o hiato, e uma vez que o escritor, de qualquer modo, tem as duas possibilidades, náo acho que este argumento seja muito forte.

O que, porém, surpreende o tradutor da obra completa de Luciano (incluindo, é claro, algumas de autoria duvidosa) é a apresentação deste Elogio de Demóstenes em duas partes, ambas em forma de diálogo, mas segundo duas técnicas diferentes.

$\mathrm{Na}$ primeira parte (\$\$1-28), o Autor (Luciano?) narra o diálogo que teve com um tal Terságoras, poeta épico e grande admirador de Homero. Esta parte da obra desenvolve-se com a indicação de quem intervém: "disse eu" ... "disse ele"... e assim por diante, algumas vezes exigindo do leitor uma atenção especial à mudança de interlocutor.

A segunda parte já apresenta o aspecto de diálogo que observamos noutros diálogos de Luciano (ou de outros...), com a indicação clara dos interlocutores: ÁRQUIAS ... / ANTÍPATRO ... / ÁRQUIAS..., diálogo este supostamente tirado de um livro "macedónico", que o Autor deste Elogio de Demóstenes lê perante a mesma audiência que estava a escutá-lo até então.

O que impressiona, no fundo, é precisamente esta dupla apresentação, em que o Autor e até então primeiro interlocutor é obrigado a justificar a mudança: “... Bem, isso é o que daqui por diante o livro vai contar”(\$29). Repito a nota: Nesta obra em forma de diálogo, temos agora um diálogo dentro de outro diálogo. Poderia muito bem constituir um opúsculo separado. 
Apesar de tudo, e contra a corrente geral, A. Bauer (apud "Loeb", VIII, p. 237) entende que a obra é de Luciano, que pretenderia fazer uma caricatura de obras similares que pululavam no seu tempo. O próprio Luciano escreveu alguns Elogio de... O fraco estilo seria, pois, propositado. A. Bauer poderá estar certo quanto à autoria de Luciano, mas náo creio que este Elogio de Demóstenes obedeça a uma intenção satírica. Pelo contrário, as qualidades literárias, cívicas, políticas, etc., de Demóstenes estâo de acordo com a ideia geral a seu respeito em toda a Antiguidade. Naturalmente, o Autor (Luciano?) conheceria bem a Vida de Demóstenes, de Plutarco (46-126 d.C.) e eventualmente outras informaçóes. Os elementos do elogio, mesmo de segunda máo, são úteis ao leitor moderno, mas é, no entanto, Terságoras, o poeta e admirador de Homero, quem acaba por fazer, nesta primeira parte $(\$ \$ 22$, ss.), o elogio de Demóstenes. Năo deixa, pois, de nos impressionar que o primeiro interlocutor (o Autor: Luciano?) funcione aqui como ouvinte de um elogio que esperaríamos fosse feito por ele próprio, e náo por um poeta.

A segunda parte, já em forma "canónica" de diálogo, pretende ser a citaçáo de um certo livro "macedónico", que se referia a Demóstenes e à sua acção na luta contra os reis expansionistas da Macedónia: Filipe, Alexandre, Antípatro. Parece não haver dúvidas de que este "livro" não passa de um engenhoso processo de dar credibilidade ao elogio do grande orador e político, feito pela parte contrária.

Afinal, a dupla técnica dialogal atrás apontada surge como um elemento, não de pobreza de inspiração, mas, pelo contrário, como obra de uma mente inventiva. E...

... Literariamente, inventar não é pecado! 


\section{Elogio de Demóstenes}

1. Passeava eu ao longo do Pórtico, pelo lado esquerdo de quem sai, no décimo sexto dia [do mês] ${ }^{120}$, um pouco antes do meio-dia, eis que vem ao meu encontro Terságoras... Talvez alguns de vós o conheçam... É um tipo baixinho, de nariz adunco, de cabeços esbranquiçados, de carácter viril. Então eu, vendo-o ainda a aproximar-se, disse: - "Para onde é que vai o poeta Terságoras? E donde vem?" Respondeu ele: - "Venho da minha casa, e agora estou aqui." E eu: - "Para dares uma passeata?" E ele: - "Sem dúvida... e bem preciso disso, pois resolvi estar levantado até altas horas da noite, a fim de celebrar o dia natalicio de Homero e dedicar-lhe uma composição poética." Ao que eu comentei: — "E fazes tu muito bem, assim pagando o preço da tua educação." "É que — disse ele - , uma vez começada a tarefa, cheguei, sem dar por isso, a esta hora do meio do dia e foi por isso que eu disse que precisava de dar um passeio...

2. “... Mas - continuou ele ${ }^{121}$ - vim aqui, antes de mais, por precisar de saudar este homem - disse apontando para [a estátua de] Homero -... vós sabeis certamente de qual se trata... a que está á direita do templo dos Ptolemeus ${ }^{122}$, aquele de cabelos escorridos... e então vim no intuito de o cumprimentar $e$ de lhe pedir que me concedesse uma farta veia poética." "Que bom que era - disse eu - que a coisa dependesse só de preces. Na verdade, creio que também eu há muito que devia incomodar Demóstenes, para que me assistisse um pouco no dia do aniversário do seu nascimento. Portanto, se nos bastasse suplicar, juntar-me-ia

${ }^{120} \mathrm{O}$ Autor não diz qual é o mês, o que, em rigor, só poderia aplicar-se a "este mês em que estamos". O contexto leva-nos a supor que se tratava do mês denominado Pianépsion, que corresponde ao "nosso" período de meados de Outubro a meados de Novembro. O dia "16" desse Mês era tido como sendo o da morte de Demóstenes. Melhor diríamos "no sexto [dia da segunda década do mês] de Pianépsion”. Ao que parece, também era a data atribuída à morte de Homero (!)...

121 "continuou (ele)", gr. simplesmente "disse (ele)", verbo que o mss. $\Gamma$ omite, uma vez que é a mesma pessoa a falar...

122 Este discurso parece ter sido pronunciado em Rodes (v. "Loeb", VIII, p. 240). Presumo que, caso fosse mesmo de Luciano, seria um discurso dos primeiros tempos de vida profissional (advogado em Antioquia e cidades do Mediterrâneo oriental....). 
a ti, pois a pretensão é comum a nós os dois." E disse ele: "Quanto a mim, julgo poder atribuir a Homero a veia poética pelo que compus durante a noite e esta manhã, pois senti-me agitado por um delírio como que divino e divinatório, que me orientou a poesia. Mas tu mesmo me julgarás, pois trouxe comigo o livrinho, para o caso de encontrar algum dos meus amigos que tivesse vagar [de o ouvir ler], e tu pareces-me estar precisamente com vagar."

3. "És um felizardo - disse eu —, por estares na mesma situação que o vencedor do 'estádio longo'123, o qual, depois de se lavar da poeira, só pensa em distrair-se durante o resto do espectáculo e contar histórias ao lutador, na expectativa de ser anunciada a [prova de] luta, ao que o dito lutador responde: 'Pois sim, mas sobre a linha de partida não há vagar para conversas'... mas tu tens antes o ar de quem acaba de vencer o 'estádio longo'... da poesia ${ }^{124}$, e agora troças de um homem que teme a sorte do estádio." Então o outro, sorrindo, exclamou ${ }^{125}$ :

"Que grandes dificuldades || vais a ti mesmo criar!" 26

4. "Sim - disse eu —, talvez te pareça que Demóstenes é de categoria inferior, quando comparado a Homero, e por isso ficas todo orgulhoso com o teu elogio a Homero, ao passo que o meu elogio a Demóstenes é pequenino e insignificante."

"Estás a caluniar-me - disse ele —, pois eu não quereria pôr esses grandes homens a rivalizar um com o outro, muito embora o meu pensamento alinhe mais em favor de Homero."

${ }^{123} \mathrm{O}$ "estádio longo", gr. dólikhos ( $\delta$ ó $\left.\lambda \iota \chi 0 \varsigma\right)$ era a maior distância que os corredores percorriam dentro do estádio, 24 comprimentos do estádio, ou 12 vezes o duplo estádio. A medida variava segundo as cidades. Em Atenas, o estádio tinha $184,98 \mathrm{~m}$, e em Olímpia $192,27 \mathrm{~m}$, o que dava uma distância, respectivamente, de c. $4.440 \mathrm{~m} / 4.615 \mathrm{~m}$... quase os nossos 5.000 metros.

124 “o 'estádio longo'... da poesia", metaforicamente, a longa poesia homérica, a que Luciano opóe o estádio normal, ou seja, um género supostamente menor: a Oratória.

$125 \mathrm{O}$ gr. tem eîpen ( $\varepsilon \tilde{i} \pi \varepsilon v)$, "disse”; há quem interprete por "perguntou”, donde a frase seguinte é ou exclamativa (como eu entendo), ou interrogativa.

126 Se tirarmos o inciso êppen ( $\varepsilon \tilde{i} \pi \varepsilon v)$, "exclamou”, a frase sai num ritmo trocaico...:

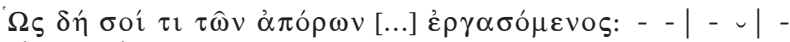
$\sim--|-\sim \sim| \sim$ 
5. "Muito bem - disse eu -... Mas acharás tu que o meu pensamento não vai em favor de Demóstenes? Mas, embora não rebaixes assim tanto a Oratória, é desde logo evidente que consideras a poesia uma actividade unica e que rebaixas abertamente o discurso oratório, tal qual um cavaleiro cavalgando ao lado de um soldado de infantaria."

"Oxalá - disse ele - eu não esteja louco, pelo menos nesta actividade... embora seja necessária uma grande dose de loucura para aqueles que vão bater à porta da Poesia."

"Na verdade — disse eu —, também os que escrevem em prosa necessitam de uma certa inspiração divina, para não parecerem muito 'rasteiros' e pobres de ideias."

"Eu sei disso, ó companheiro — disse ele —, e muitas vezes até me comprazo em comparar as obras de Homero com as dos outros prosadores, nomeadamente Demóstenes, referindo qualidades como veemência, mordacidade e inspiração, ou comparando aquele 'pesado de vinho' ${ }^{127}$ com as bebedeiras de Filipe, as suas danças licenciosas e a sua devassidão, ou o 'é este o melhor augúrio'128 com 'os homens bons devem abrigar boas esperanças', ou

'soltaria altos lamentos || Peleu, velho cavaleiro'129,

com 'que altos lamentos soltariam aqueles homens que morreram pela glória e pela liberdade!'. Comparo ainda 'o facundo Píton'130 com as 'os flocos de neve' das palavras de Ulisses, ou

'se nós os dois pudéssemos viver $\|$ da velhice libertos e da morte' ${ }^{131}$, [comparado] com 'na verdade, para todos os homens o fim da vida é a morte, mesmo que se encerrasse numa cela e aí permanecesse'... e milhares de outras ocorrências destes autores, todas no mesmo sentido...

6. “... Gosto de [observar] as suas situaçōes dramáticas, as suas descriçôes, as suas figuras de estilo, as variações que afastam o

${ }^{127}$ Ilíada, I, 225. Aquiles 'brinda' Agamémnon com este forte adjectivo, vocat. oinobarés (oỉvo $\beta \alpha \rho \varepsilon$ s), além de "olhos de cão" e "coração de gamo" (este último = "cobarde")...

${ }^{128}$ Homero, Ilíada, XII, 243; a citação seguinte é de Demóstenes, Discurso da Coroa, 97.

129 Homero, Ilíada, VII, 125; a citação seguinte é de Demóstenes, Contra Aristócrates, 210.

${ }^{130}$ Píton foi mandado a Tebas por Filipe, com a missão de acusar os atenienses de terem traído a causa comum.

${ }^{131}$ Homero, Iliada, XII, 322-324; a citação seguinte é de Demóstenes, Discurso da Coroa, 97. 
tédio, as retomas do tema depois das digressóes, a elegância das suas oportunas comparaçóes, enfim, por toda a parte uma linguagem que rejeita os barbarismos...

7. “... Muitas vezes até me pareceu (realmente, não devo esconder a verdade) que Demóstenes - o qual, por um lado, como sói dizer-se, é desenfreado na sua franqueza - critica a indolência ática com mais vigor do que aquele que chamou 'Aqueias' aos Aqueus ${ }^{132}$, e que, por outro lado, traduz as desgraças gregas com um fôlego de espirito mais amplo que o daquele que, no ponto culminante da luta, intromete diálogos e dissipa a acção com as suas histórias...

8. “... Muitas vezes, o estilo de Demóstenes... as cláusulas métricas $^{133}$, os ritmos e a cadência [da frase]... tudo isso me dá uma impressão que não anda longe do prazer poético, tal como, por outro lado, Homero não tem falta de antiteses, de paralelismos, de figuras arrojadas ou de grande delicadeza. Parece que se dá o caso de os seus génios estarem ambos entrelaçados pela natureza e pela arte ${ }^{134}$. Então como é que eu poderia menosprezar Clio, depois de the reconhecer valor idêntico ao de Caliope?"135

9. "Em todo o caso [- continuou Terságoras - ], não deixo de considerar que a minha declamação sobre o elogio de Homero seja uma tarefa duas vezes mais difícil que o teu elogio de Demóstenes... não tanto pela forma métrica..."

${ }^{132}$ Trata-se do famoso passo em que Tersites, o mais feio e o mais insolente dos Gregos, solta uma dura invectiva contra Agamémnon (Ilíada, II, 225-242), incluindo na sua crítica os Aqueus (Gregos), que assistem indiferentes ao comportamento de Agamémnon em relaçáo a Aquiles, e por isso lhes chama (imagine-se!)... "Aqueias".

${ }^{133} \mathrm{Tal}$ como Cícero entre os Romanos, Demóstenes terminava geralmente os períodos ou partes de períodos, com determinadas sequências de sílabas longas e breves, diferentes dos ritmos da poesia, mas de uma constância notável, que agradava ao ouvido e tornava a sua prosa... poética, como p.ex. a sequência $-\smile \_\smile$ V., além dos tratados de métrica grega e latina, The Oxford Classical Dictionary, s.u. PROSE-RHYTHM

${ }^{134}$ A frase é "complicada", mas o sentido parece ser o de que tanto em Homero como em Demóstenes houve uma conjugação de qualidades naturais e arte adquirida.

${ }^{135} \mathrm{O}$ texto deste período, certamente alterado nos mss., tem sofrido diversas emendas, uma das quais (não a da "Loeb") eu admito, ainda que, segundo os princípios da crítica textual (que não têm força absoluta!), se trate da emendatio difficilior. 
"Em que é que te baseias?" - perguntei eu.

"... [Baseio-me] no facto de não poder dar ao meu elogio uma fundamentação sólida, a não ser a que consta dos próprios poemas. Os outros dados são incertos: a sua pátria, a sua familia, o tempo em que viveu. Se houvesse informaçáo segura a seu respeito,

'não haveria entre os homens || uma disputa indecisa'136, em que lhe dão por pátria Ios, ou Cólofon, ou Cime, ou Quios, ou Esmirna, ou Tebas do Egipto, e muitas outras; quanto ao seu pai, dizem que foi Méon da Lidia, ou um rio, e alguns preferem [dar-lhe] o nome de 'Melesigenes'137, em vez do nome usual; e dizem que sua mãe foi a filha de Melanopo ou, à falta de uma ascendência humana, uma ninfa de entre as Hamadriades ${ }^{138}$; teria vivido no periodo heróico, ou no jónico, e nem se sabe com segurança a sua época relativamente a Hesiodo; no que toca à sua condição, dizem que era pobre e doente dos olhos ${ }^{139}$. Talvez seja melhor deixar ficar na incerteza estas matérias. O meu elogio é realmente muito limitado, reduzido a louvar uma poesia sem contexto [biográfico] e a recolher uma sabedoria retratada só com base nos seus versos...

10. "A tua tarefa, porém - continuou Terságoras —, está ao teu alcance, é 'corredia' e 'plana', assente em factos concretos e bem conhecidos... é só pôr lá as palavras ${ }^{140}$, como um prato já pronto, que só precisa de uns temperos. Realmente, que facto grandioso e brilhante é que a fortuna não concedeu a Demóstenes? Que facto desconhecido? Nấo foi Atenas a sua pátria, essa [cidade]

'opulenta, gloriosa, || o baluarte da Grécia'?'141

Mas se eu tivesse de pegar no tema de Atenas, introduziria, apoiado na liberdade poética, amores de deuses, os seus julgamentos, as suas estadas [na cidade], as suas dádivas, os mistérios de Elêusis... Quanto às suas leis, os seus tribunais, os seus festivais, o seu Pireu,

${ }^{136}$ Eurípides, Fenícias, 500.

137 Melesígenes significa "filho de Meles" (ou... de Melete)... o que nada adianta...

${ }^{138}$ As Hamadríades eram ninfas das árvores, e morriam quando estas secavam ou eram cortadas.

139 "doença de olhos", espécie de eufemismo, por "cego".

140 "é só pôr lá as palavras" é interpretação minha de um passo algo difícil... talvez adulterado.

${ }^{141}$ Píndaro, fragmento de uma obra perdida. 
as suas colónias e os seus monumentos, também aqui introduzidos, dedicados aos triunfos no mar e em terra, ninguém, como diz Demóstenes, seria capaz de, por palavras, os evocar na sua justa medida. Eu disporia de uma grande abundância de dados, mas o meu elogio [de Atenas] náo seria considerado fora de propósito, uma vez que faz parte das regras do elogio exaltar os elogiados, fazendo referência às respectivas pátrias. Assim, Isócrates, ao falar de Helena ${ }^{142}$, meteu, como acessório, a figura de Teseu. Realmente, a raça dos poetas é muito livre! Mas talvez tu tenhas a prudência de evocar aquele provérbio que se refere jocosamente à justa proporção: 'Não se ponha uma etiqueta grande de mais para o saco'.

11. "Mas deixemos Atenas e, em continuação do meu discurso, diga-se que o seu pai era trierararco ${ }^{143}$, um 'alicerce de ouro', como diz Pindaro. Realmente, não havia em Atenas um cargo mais brilhante que o de trierarco. Embora ele tenha morrido quando Demóstenes era ainda uma criança, não devemos considerar a sua orfandade como uma desgraça, mas sim como uma circunstância de glória, que pôs a descoberto a nobreza da sua indole...

12. "No que diz respeito a Homero, não possuimos qualquer registo histórico relativo à sua educação e à sua actividade, mas somos forçados a traçar o seu elogio directamente baseado nas suas obras-primas, as quais não nos transmitem informaçóes concretas sobre a sua educação, os seus estudos e a sua formação escolar, sem que ao menos possamos recorrer ao ramo de loureiro de Hesiodo, que fornece inspiração até mesmo a versos de pastores. Mas tu tens à tua disposição o prolífico Calistrato e o seu brilhante Catálogo ${ }^{144}$, [onde figuram] Alcidamas, Isócrates, Iseu, Eubúlides. Num tempo em que havia em Atenas mil prazeres que seduziam até mesmo aqueles [jovens] que estavam fortemente sujeitos ao poder paternal ${ }^{145}$, em que a idade é propicia a que os adolescentes se deixem

${ }^{142}$ Trata-se do Elogio de Helena. Teseu entra nesse tema, pelo facto de, juntamente com o seu amigo Pirítoo, numa visita a Esparta, terem raptado Helena... uma história que sugere a "outra" a que é contada por Homero.

${ }^{143} \mathrm{O}$ trierarco (melhor que trierarca) era o comandante da frota ateniense, ou um cidadão rico que equipava uma trirreme a expensas suas.

144 "o prolífico Calistrato e o seu brilhante Catálogo": o gr. é confuso. Sugiro que se trata de um tal Calístrato, filólogo do período helenístico, que teria elaborado um catálogo dos oradores... ...

${ }^{145} \mathrm{O}$ pai de Demóstenes morreu que ele tinha sete anos, pelo que ficou entregue a três tutores, dois tios e um amigo do pai. 
arrastar para a devassidão, e para mais tendo a liberdade [para assim proceder], devido à negligência dos seus tutores, apoderou-se de Demóstenes a paixáo pela Filosofia e pela virtude civica, que o encaminhou, não para a porta de Frine ${ }^{146}$, mas para as [portas] de Aristóteles, de Teofrasto, de Xenócrates e de Platão.

13. "Neste ponto, meu caro, poderias referir no teu discurso, de cariz filosófico, os dois impulsos amorosos que se exercem sobre os homens, ou seja, o do amor, digamos assim, 'marinho', [impulso] frenético, selvagem e tempestuoso dentro da alma, uma tormenta da Afrodite popular, uma coisa autenticamente marinha e com a fogosidade inflamada dos jovens, e o outro [impulso], aquele que nos puxa por meio de uma espécie de corda de ouro celestial, que náo provoca, com fogo e flechas ${ }^{147}$, doenças incuráveis de natureza traumática, mas que impele [o homem] para a pura e limpida Ideia da própria Beleza, [que actua] nas almas com uma sábia loucura, e que, como diz o poeta trágico ${ }^{148}$ :

\section{'Estão $0^{149}$ bem perto de Zeus $\|$ e são dos deuses parentes'.}

14. "Tudo concorre para esta paixão $o^{150}$ : cabeça rapada, uma caverna, um espelho, uma espada, correcção da pronúncia, imitação de uma idade [mais] avançada, rigoroso exercicio da memória, aversão ao tumulto, encadeamento das noites com dias [inteiros] de trabalho penoso... Quem desconhece aquilo em que, graças a estes processos, o teu Demóstenes se tornou em termos de oratória, assim adensando o seu estilo do ponto e vista do pensamento e da sua expressão linguistica e afinando o poder persuasivo por meio da disposição [dos factos], brilhante na sua imponência, impetuoso no sopro da voz, extremamente comedido no dominio das palavras e dos conceitos e muito versátil na mudança de figuras

${ }^{146}$ Frine era uma famosa meretriz, amante que foi amante, entre outros, do orador Hiperides.

147 Referência clara às setas de Eros (Cupido).

148 Ésquilo, fragmento da tragédia Niobe.

${ }^{149} \mathrm{O}$ sujeito de todo este verso é Ideias e Beleza.

${ }^{150}$ Refere-se a Demóstenes e ao processo muito peculiar de aperfeiçoamento oratório, sobretudo na postura e na pronúncia, como se diz a seguir. Demóstenes meteu-se numa caverna, rapou metade da cabeça para, por vergonha, náo sair de lá, arranjou um espelho para aperfeiçoar a expressáo facial, aperfeiçoou a pronúncia; a espada suspensa sobre si evitava que ele se movesse excessivamente, etc. (v. a seguir). 
[de retórica]? Como ousou afirmar Leóstenes ${ }^{151}$, ele era o único de entre os oradores que produzia um discurso palpitante de vida e [bem] 'martelado' 152 .

15. "Realmente, ao contrário de Ésquilo, o qual, segundo disse algures Calistenes, escrevia as suas tragédias sob a acção do vinho, assim excitando a reaquecendo a alma, Demóstenes não compunha os seus discursos embriagado, mas à força de beber água. Dizem que, por esse facto, Demades troçava desta sua 'ingestão de água', dizendo que, enquanto uns 'falam para a água'153, Demóstenes 'escreve para a água'. Para Piteas, o fragor dos discursos de Demóstenes parecia-lhe cheirar à sua candeia nocturna, e este [último] ponto do teu discurso é comum à minha temática. De facto, o meu discurso a respeito da poesia de Homero não seria menos extenso [que o teu]...

16. “... E se passares aos seus actos humanitários, ao uso generoso do seu dinheiro e a todo o brilho da sua acção política..." E já ele avançava para acrescentar uma série das restantes qualidades, quando eu, sorrindo, lhe disse: "Será que estás a pensar em me inundar os ouvidos, despejando sobre eles o teu discurso, tal qual um empregado de balneário? ${ }^{154 ”}$

"Sim, por Zeus! - respondeu ele —, e ainda os banquetes públicos, as suas funçôes de corego ${ }^{155}$ voluntário, os [vários] equipamentos de trirremes, as muralhas, ofosso, os resgates de prisioneiros de guerra, os dotes de donzelas, o seu excelente serviço público, as funçóes como embaixador, as suas propostas de lei, enfim, a grandeza da sua acçâo politica... Quando penso em tudo isso,

151 Leóstenes, general e político ateniense.

152 'martelado'é a trad. literal (mas obviamente metafórica) de (acusat.) sphürélaton ( $\sigma \varphi v \rho \eta ́ \lambda \alpha \tau o v)$, talvez no sentido de "bem ritmado", ou seja, com alusão às chamadas cláusulas métricas; outro sentido possível é "bem trabalhado". Deixo ficar a versão literal...

153 'falam para a água', alusão à clepsidra ou relógio de água, que marcava o tempo de intervenção das partes em tribunal.

${ }^{154}$ É bem risonha a comparação com um empregado de balneário a despejar baldes de água sobre o banhista, como complemento do banho e limpeza completa...

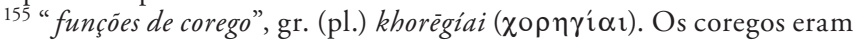
os cidadãos mais ricos, escolhidos para custearem os festivais públicos e outras necessidades do Estado. Neste caso, Demóstenes oferecia-se voluntariamente para desempenhar essas funçóes, já de si muito prestigiantes. 
sou levado a rir de quem ${ }^{156}$ franze as sobrancelhas, com receio de que lhe faltem as palavras adequadas aos feitos de Demóstenes."

17. "Acaso julgas, men caro — repliquei eu —, que eu sou o único que, tendo passado a vida envolvido na oratória, não tive os ouvidos cheios dos feitos de Demóstenes?!"

"Sim — disse ele —, se realmente, como tu dizes, precisamos de alguma ajuda para [fazer] o discurso... a menos que se apodere de ti o sentimento contrário e que, devido ao seu brilho intensissimo, não possas fixar os olhos na brilhante glória de Demóstenes. Na verdade, eu próprio, ao princípio, tive idêntica sensaçâo relativamente a Homero. Então, pouco faltou para baixar os olhos, como se náo pudesse olhar de frente essa realidade. Depois, náo sei como, levantei os olhos, e agora, a pouco e pouco acostumado a olhar de frente e por já não desviar os olhos dos 'raios do sol', creio < já não $>157$ poder ser considerado um bastardo da familia dos Homéridas...

18. “...Num ponto - continuou Terságoras - a tua tarefa afigura-se-me muito mais fácil que a minha. De facto, estando a glória de Homero firme somente na sua pujança poética, eu tinha, por força, de retirar dai toda a informação, ao passo que tu, se te virasses de uma só vez e de alma e coração para Demóstenes no seu todo, ficarias num grande embaraço, às voltas com o teu discurso, sem saberes em que ideia pegar em primeiro lugar, tal como acontece com os glutóes à volta das mesas siracusanas ${ }^{158}$ ou com as pessoas apaixonadas pela música ou pelos espectáculos, e que têm à sua disposição mil prazeres auditivos ou visuais, mas não sabem a qual acorrer, e então mudam constantemente o seu desejo. Julgo que também tu saltas de uma qualidade para outra, sem saberes em qual te deves fixar, pois todas sucessivamente te atraem: a sua indole magnificente, a sua fogosidade inflamada, a sua vida sóbria, o seu estilo veemente, a sua coragem nas acçóes, o seu desprezo de muitos e grandes lucros, o seu sentido de justiça, a sua filantropia, a sua lealdade, o seu bom senso, a sua

${ }^{156}$ Trata-se obviamente do interlocutor de Terságoras: Luciano (ou o autor...).

157 O texto é algo confuso. Sem o 'meu' acrescento, diríamos que Terságoras se considera, humildemente, um "bastardo" da família dos Homéridas...

${ }^{158}$ A gastronomia siciliana (Siracusa, Síbaris...) era célebre pela fartura, diversidade e requinte. 
inteligência, enfim, cada um dos seus numerosos e grandes serviços públicos. Talvez por isso, ao veres, por um lado, os seus decretos, as embaixadas [em que participou], os seus discursos e as suas leis, e, por outro lado, as suas expediçóes navais, como Eubeia, Mégara da Beócia, Quios, Rodes, o Helesponto e Bizâncio, ficas sem saber para onde virar o pensamento, rodopiando sucessivamente por todas estas virtudes...

19. “... tal como Pindaro, que, dirigindo o seu espirito para muitas coisas, ficou embaraçado:

'Cantaremos nós Ismeno, || ou Mélia de roca de oiro, ou Cadmo mais a sagrada \| raça de homens semeados ${ }^{159}$, ou então a jovem Tebe ${ }^{160}, \|$ a de cintura purpúrea, ou de Héracles o vigor $\|$ que tudo ousa cometer, ou de Dioniso o dom || que causa grande euforia, ou as bodas de Harmonia, $\|$ a deusa de niveos braços?'

"Do mesmo modo, também tu me pareces embaraçado, sem saber se deves celebrar os discursos do homem, ou a sua vida, ou a sua filosofia, ou a sua capacidade de liderança de massas ${ }^{161}$, ou a sua morte...

20. “... Em todo o caso - continuou Terságoras —, não é tarefa difícil evitar a hesitaçâo, mas, pegando em qualquer destes aspectos, por exemplo a arte oratória em si mesma, faz incidir sobre esta o teu discurso. Mesmo assim, a eloquência de Péricles não será suficiente. Antes de mais, ainda que dela tenhamos um conhecimento tradicional sobre os seus 'raios' e 'trovóes' e sobre uma espécie de 'aguilhão' persuasivo, a verdade é que não vemos essa eloquência, a qual não passa de uma ideia que persistiu, mas que não resiste à prova e ao julgamento do tempo ${ }^{162}$. Pelo

${ }^{159}$ Cadmo deu início a uma nova raça de homens, semeando dentes de dragão, donde nasceram os Spartoí ( $\Sigma \pi \alpha \rho \tau o$ ó), ou seja, os Espartanos, lit. ${ }^{\text {te }}$ "semeados".

${ }^{160}$ Há diversas heroínas com esse nome. Aqui, talvez uma filha de Prometeu e de uma ninfa...

161 "capacidade de liderança de massas", gr. démagōgía ( $\delta \eta \mu \alpha \gamma \omega \gamma i \alpha)$, que por vezes (mas não neste caso!) tem o nosso sentido pejorativo de "demagogia". O mesmo se diga do dēmagögós ( $\delta \eta \mu \alpha \gamma \omega \gamma o ́ \varsigma)$, "condutor e orientador do Povo", ou, pejorativamente, "demagogo".

162 Julgo que se refere aos aspectos visuais e auditivos da oratória de Péricles, irremediavelmente irrecuperáveis... mas não no caso de Demóstenes, em que tais pormenores são... legíveis - sugestão não explícita, pois Terságoras é aqui interrompido pelo seu interlocutor. 
contrário, as obras de Demóstenes... Bem... dou-te a palavra a ti, se quiseres virar-te para este aspecto...

21. "... Mas, se entenderes virar-te para as suas virtudes de alma e as da acçâo cívica, é bom que consideres à parte um único tema, ou, se pretenderes alargar-te mais, escolhe um grupo de dois ou três [aspectos], e já terás material quanto baste para a tua exposição, pois em todas elas existe muito brilhantismo. Se, porém, queremos elogiar, não o todo, mas só uma parte, siga-se a norma homérica de traçar elogios parciais dos heróis, como os pés, a cabeça, a cabeleira, algumas vezes o seu equipamento ou o seu escudo... e é que nem os deuses desdenharam de serem celebrados pelos poetas a respeito da sua roca, do arco ou da égide, para já não mencionar alguma parte do corpo ou [virtude] da alma, de tal modo que não seria possivel mencionar um por um todos os seus dons. Portanto, Demóstenes não te acusará pelo facto de ser elogiado por uma unica das suas qualidades, uma vez que nem sequer ele teria capacidade de se elogiar a si próprio no seu todo.

22. Tendo Terságoras assim falado, eu disse: "Creio que tu acabas de me revelar [mais] uma qualidade, ou seja, que não és apenas um bom poeta, ao incluíres Demóstenes, como acessório, na tua dedicatória [a Homero], acrescentando prosa aos teus versos."

"A verdade é que — respondeu Terságoras —, ao sugerir-te a facilidade [da tua tarefa], fui levado a estender o discurso, a ver se tu, aliviado da tua preocupação, te disporias a ser meu ouvinte."

"Pois — disse eu —, fica sabendo que não adiantaste nada. Vê lá mas é se a minha tarefa não ficou ainda mais difícil."

"Mas dir-se-ia — replicou ele - uma bela cura."

"É que tu - disse eu - desconheces, creio, o meu actual embaraço, e então, à maneira de um médico que, por não saber qual é a moléstia do doente, trata-o de outro mal."

"Que queres dizer com isso?"

"É que tu tentaste tratar-me daquele mal que perturbaria uma pessoa que desse os primeiros passos na arte oratória, mas esse mal já está desde há longo tempo ultrapassado, pelo que, para tais dificuldades, os teus remédios já passaram de moda."

"Pois é mesmo aí-disse Terságoras - que está a tua cura. Há que proceder como com um caminho: o mais utilizado é o mais confiável." 
23. "Na verdade — respondi eu - proponho-me seguir o caminho contrário àquele que, segundo dizem, seguiu Aniceris de Cirene, a fim de suscitar a admiração de Platão e dos companheiros deste, ou seja, para demonstrar a perícia dos Cirenaicos como condutores de carros, deu muitas voltas à Academia, todas sempre pelo mesmo rodado [do seu carro], sem sair do trilho, por pouco que fosse, de maneira que deixou no terreno as marcas de uma só passagem. Ora, o que eu ansiosamente ${ }^{163}$ procuro é uma via contrária, ou seja, evitar as 'marcas de rodado', embora náo seja muito fácil, julgo eu, ser original desviando-me dos caminhos batidos."

"Nesse caso — disse ele —, o método de Páuson é muito hábil." "Que método? - disse eu - Nunca ouvi falar..."

24. "Diz-se que foi encomendado ao pintor Páuson que pintasse um cavalo a espojar-se. Então ele pintou o cavalo a galope e com muita poeira à sua volta. Ora, estando ele em plena pintura, chegou aquele que tha havia encomendado, que o repreendeu, dizendo que não era isso o que lhe tinha mandado fazer. Então Páuson virou para o lado de baixo a parte de cima do quadro e ordenou ao criado que mostrasse a pintura ao outro, e entáo viu-se o cavalo ao contrário, ou seja, deitado [no chão] e rebolando-se [na poeira]."

"És muito ingénuo, Terságoras — disse eu —, se cuidas que eu, durante tantos anos, só imaginei uma única alternativa e que não tenho [sucessivamente] mudado e alterado todas as alternativas, de tal maneira, que receio bem que me aconteça o mesmo que a Proteu ${ }^{164}$."

"Que aconteça o quê??"

"Aquilo que dizem que lhe aconteceu, ao procurar uma forma de fugir à vista dos humanos: depois de ter esgotado todas as formas de animais, de plantas e de elementos [da Natureza] ${ }^{165}$, à falta de uma nova forma, voltava a ser Proteu."

25. "Mas tu — replicou Terságoras — tens manhas superiores a Proteu, para te furtares a escutar-me."

163 "ansiosamente" (ou "ardentemente") está implícito no verbo speúdō $(\sigma \pi \varepsilon v ́ \delta \omega)$.

${ }^{164}$ Proteu era um deus marinho, encarregado de apascentar as focas de Posídon. Tinha em elevado grau o dom da profecia e da metamorfose: podia transformar-se em tudo o que quisesse, . ex., leão, serpente, pantera, javali, água, árvore, fogo...

${ }^{165}$ Referência aos quatro elementos: terra, água, ar e fogo. 
"Não, meu caro - disse eu -, nada disso. Pois então vou dispor-me a escutar-te, pondo de lado a preocupação que me assaltou. Talvez tu, ao ficares de certo modo livre de preocupação com o teu 'parto 166 , possas partilhar também da minha dor [de 'parto']."

Como Terságoras concordasse, sentámo-nos num degrau ali perto, onde eu o ia escutando a recitar uns versos muitíssimo nobres. Mas, a meio [da recitação], como que possuído de uma inspiração divina, enrolou o livro ${ }^{167}$ e disse: "Vais receber 168 os honorários de orador, como em Atenas há os de membro da Assembleia e de jurado do tribunal. Oxalá saibas agradecer-me."

26. "Sim, saberei agradecer-te — disse eu -... mesmo antes de saber do que é que estás a falar... Mas do que é que estás a falar?"

"Tendo eu dado por acaso - disse ele - com umas Memórias sobre a casa real da Macedónia, fiquei extremamente deleitado, de tal modo, que adquiri o livro, não como coisa de importância secundária... e mesmo agora me lembrei que o tenho em casa. Ai estäo registados, além dos actos de política interna praticados por Antipatro ${ }^{169}$, os episódios referentes a Demóstenes, que creio que tu ouvirás ler como coisa de não somenos importância."

"Pois sim - disse eu —, mas, como agradecimento por essa boa-nova, lê o resto do teu poema. Cá por mim, náo desisto de ver cumprida a tua promessa... mas tu, depois de tão brilhantemente me brindares com o aniversário de Homero, pareces ir brindar-me também com o de Demóstenes."

27. Quando Terságoras acabou de ler o resto do rolo, ficámos ali ainda algum tempo, o suficiente para prestarmos ao poema o seu justo elogio, após o que nos dirigimos a casa de Terságoras. Este, embora com alguma dificuldade, lá deu com o rolo. Então eu peguei [no dito rolo] e retirei-me. Depois de ler o livro, fiquei num tal estado de espírito, que

166 Referência ao poema que compusera em honra de Homero (v. \$1). 167 "o livro", quer dizer, o rolo de papiro.

168 “Vais receber", e não "'recebe" ou "toma lá", ou seja, usa-se, não o imperat. aor. (momentâneo), e não o imperat. presente (contínuo...).

${ }^{169}$ Antípatro (397-319 a.C.), general de Filipe da Macedónia e de Alexandre, impôs a Atenas um regime oligárquico, que mereceu a fortíssima oposiçáo, entre outros, de Demóstenes, o qual, para não se render, preferiu suicidar-se por envenenamento. 
resolvi ler-vos ${ }^{170}$ tudo, palavra por palavra e frase por frase, sem modificar o que quer que fosse. Na verdade, náo se presta menor homenagem a Asclépio, se o péan não é da autoria daqueles que o visitam, mas canta-se antes um de Isodemo ${ }^{171}$ de Trezena ou de Sófocles; do mesmo modo, embora se tenha deixado de escrever comédias e tragédias [originais] em honra de Dioniso, as [peças] compostas por outros ${ }^{172}$ tornam os que actualmente as levam à cena dignos de uma gratidáo náo inferior, pelo facto de pretenderem também eles homenagear esse deus.

28. Agora no que diz respeito ao tal livro - do qual a apresentação dramática que se segue constitui a parte das Memórias que nos interessa - , esse livro conta que Árquias se apresentou para ser anunciado a Antípatro. Este Árquias - caso algum dos mais novos o desconheça - tinha sido encarregado de prender os exilados ${ }^{173}$. Foi-lhe ordenado que persuadisse Demóstenes a deixar Caláuria, de preferência a trazê-lo à força à presença de Antípatro. Por isso, Antípatro estava excitado por esta expectativa, aguardando a todo o momento a chegada de Demóstenes. Portanto, ao ser informado de que Árquias tinha chegado de Caláuria, ordenou que o fizessem entrar imediatamente, tal como estava...

29. ... Logo que ele entrou... Bem, isso é o que daqui por diante o livro vai contar ${ }^{174}$.

170 "ler-vos": Obviamente, não se trata de um plural majestático, referido só a Terságoras, pois este já tinha lido o livro. Por isso, podemos imaginar que se trata de uma leitura pública.

${ }^{171}$ Os mss. estão aqui nitidamente corrompidos, suscitando, por isso, diversas tentativas de emenda moderna. Sigo, sem convicçáo, a de A. M. Harmon (v. "Loeb”, VIII, pp. 269, 271); a emenda de Keil (apud "Loeb”) é igualmente arriscada...

172 "por outros", i. é, os antigos comediógrafos e tragediógrafos.

${ }^{173}$ Depois da derrota na batalha de Cránon (322 a.C.), muitos atenienses refugiaram-se onde puderam. Demóstenes fugiu para a ilha de Caláuria, onde se suicidou, para náo ser detido. Nota: Estão registadas as formas

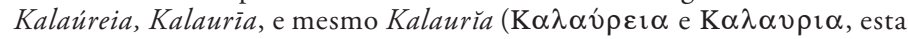
com 1 longo e breve); em lat. registam-se Calaurĭa e Calaurēa (Ovídio). A adaptação "canónica” em port. daria Calauría (grave).

${ }^{174}$ Nesta obra em forma de diálogo, temos agora um diálogo dentro de outro diálogo. Poderia muito bem constituir um opúsculo separado. 


\section{ÁRQUIAS - Alegra-te ${ }^{175}$, Antípatro.}

ANTÍPATRO - Porque náo haveria de me alegrar, se tu me trouxeste Demóstenes?

ÁRQUIAS - Trouxe-to... como foi possível. Na verdade trago comigo a urna com os restos de Demóstenes

ANTÍPATRO - Tu goraste as minhas expectativas, ó Árquias. Sim, de que me servem os ossos e a urna, se não tenho Demóstenes?

ÁRQUIAS - Na verdade, ó rei, não me foi possível segurar à força a sua alma.

ANTÍPATRO - Porque é que não o apanhastes vivo?

ÁRQUIAS - Nós apanhámo-lo...

ANTÍPATRO - Quer dizer que morreu no caminho?

ÁRQUIAS - Não, mas onde ele se encontrava, em Caláuria.

ANTÍPATRO - Porventura isso aconteceu devido a negligência vossa, por não terdes cuidado do homem?

ÁRQUIAS - É que isso não dependia de nós...

ANTÍPATRO - Que é que queres dizer [com isso]? O que me contas é um enigma: apanhastes o homem vivo e não o tendes?

30. ÁRQUIAS - Então não nos ordenaste que não usássemos logo de início de violência? Mas nem usando de violência conseguiríamos mais. De facto, íamos mesmo preparar-nos para...

ANTÍPATRO - Não fizestes bem em preparar-vos... Será que ele morreu devido a violência vossa?

ÁRQUIAS - Nós não o matámos, mas, não conseguindo persuadi-lo, precisávamos de usar de violência. Mas que ganharias tu, ó rei, se ele aqui chegasse vivo? De toda a maneira, não faríeis outra coisa senão matá-lo.

31. ANTÍPATRO - Cuidado com a língua, ó Árquias. Parece-me que não percebeste nem que espécie de homem era Demóstenes, nem o meu conceito sobre ele, mas julgas que é a mesma coisa encontrar Demóstenes ou procurar esses miseráveis de má morte, como Himereu de Falero, ou Aristonico de Maratona, ou Êucrates do Pireu, em nada diferentes das torrentes impetuosas, uns tipos reles, que estiveram na crista

175 "Alegra-te", khaîre ( $\chi \alpha$ ĩ $\rho$ ) é a tradução literal (em vez de "Ora viva”, "Eu te saúdo”...), e aqui obrigatória, pois, como se vê a seguir, é precisamente no sentido literal que Antípatro quer entender a saudação. 
da onda aproveitando-se de oportunos tumultos e que se insurgiram ao menor sinal de motim, mas que, passado náo muito tempo, "amainaram", como os ventos do crepúsculo... ou como o falso Hiperides, esse bajulador do Povo, que náo considerava vergonhoso caluniar Demóstenes usando a bajulação junto das massas e que, nessa acçáo, se apresentava como servidor destas [mesmas massas], acçôes de que se arrependeram aqueles mesmos a quem ele tentava agradar. De facto, não muito tempo depois dessa calúnia, Demóstenes teve, segundo ouvimos dizer, um regresso [à Pátria] ainda mais brilhante do que o de Alcibíades. Mas Hiperides não se preocupava nem tinha pejo de usar, contra os seus maiores amigos de outrora, aquela língua que eu fiz bem em lhe cortar, devido à sua ingratidão.

32. ÁRQUIAS — Mas então... não era Demóstenes o nosso pior inimigo?

ANTÍPATRO — Não para quem aprecia a lealdade de carácter e considera estimável uma maneira de proceder franca e firme. Realmente, as boas qualidades são [sempre] boas qualidades, mesmo num inimigo, e a virtude, esteja onde estiver, é digna de apreço. Ora, eu não sou pior que Xerxes, o qual, cheio de admiração pelos lacedemónios Búlis e Espérquis, deixou-os ir [em paz], quando podia matá-los ${ }^{176}$. Mas se, de entre todos os homens, eu admirei algum, esse é Demóstenes, com o qual me encontrei duas vezes em Atenas, e mesmo assim sem grande demora, e também por ter sido informado por outros. Mas eu admirava-o pelas suas actividades públicas em si mesmas, e não tanto, como alguém poderia julgar, pelo seu talento oratório, ainda que, comparado com ele, o nosso Píton ${ }^{177}$ não seja nada, e os [discursos dos] oradores áticos sejam uma brincadeira de meninos ${ }^{178}$ comparados com a voz atroadora e forte

${ }^{176} \mathrm{O}$ caso é contado por Plutarco, Moralia, 235F e 815E, e também por Heródoto, VII, 134, ss. Como os Espartanos tivessem assassinado os dois enviados de Xerxes, foi decidido enviar a este dois espartanos, aliás voluntários, para que os Persas lhes aplicassem o mesmo tratamento. Xerxes, tocado de admiração por esse gesto, entendeu náo proceder como haviam feito os Espartanos...

177 Píton, enviado de Filipe da Macedónia a Atenas, talvez o mesmo que foi general de Alexandre e faria agora parte da corte de Antípatro (?).

178 "brincadeira de meninos", paidiá $(\pi \alpha \iota \delta \imath \alpha)$ : somos tentados a ler paidía $(\pi \alpha$ ı $\delta \underline{i} \alpha)$, “(uns) meninos”. Neste caso, não incluiria, entre parênteses rectos, [discursos dos]. 
de Demóstenes, o ritmo das frases ${ }^{179}$, as definiçôes precisas ${ }^{180}$ das ideias, o encadeamento das demonstraçóes, o seu poder persuasivo e a sua retumbância. Por isso nos arrependemos daquele dia em que reunimos os Gregos em Atenas, no intuito de desacreditar os Atenienses, tentando convencê-los através de Píton e das promessas de Píton... mas logo a seguir vimo-nos confrontados com Demóstenes e as suas acusaçōes. Na verdade, a força da sua palavra era inigualável.

33. Todavia, eu classificava essa sua qualidade [oratória] como secundária e colocava-a no plano das "ferramentas", mas acima de tudo admirava Demóstenes pela sua sensatez, pela sua inteligência, conservando um espírito de rectidão inflexível em todas as tempestades da fortuna e não cedendo a nenhuma adversidade. Sei que Filipe tinha a respeito desse homem a mesma opinião que eu. Uma vez, em que lhe tinha sido comunicado, de Atenas, um discurso público que atacava Filipe, e como Parménion se tivesse exprimido furiosa e sarcasticamente contra Demóstenes, Filipe disse-lhe: "Ó Parménion, Demóstenes está no seu direito à liberdade de palavra. Pelo menos, é ele o único de entre os chefes populares, em toda a Grécia, que não está inscrito no registo das minhas despesas. Em todo o caso, antes queria confiar nele, do que nos contabilistas das minhas trirremes. ${ }^{181}$. Presentemente, cada um destes, sem excepção, está registado como tendo recebido de mim ouro, ou madeira, ou trigo, ou gado, ou um terreno na Beócia. Então nós mais depressa tomariamos as muralhas de Bizâncio ${ }^{182}$ com máquinas de assalto, do que [tomariamos] Demóstenes a poder de ouro...

34. “... Cá por mim, ó Parménion - continuou Filipe -, se alguém, na qualidade de ateniense, e em Atenas, dissesse que prefere a minha pessoa à sua própria Pátria, eu oferecer-lhe-ia ${ }^{183}$ o meu ouro, mas não a minha amizade. Se, pelo contrário, alguém me odeia em prol da sua Pátria, eu faço a guerra contra ele,

${ }^{179}$ V. $\$ 18$, nota a cláusulas métricas.

180 "definiçóes precisas" tenta traduzir (dat. pl.) perigraphâ̂s ( $\pi \varepsilon \rho \imath \gamma \rho \alpha \varphi \alpha \hat{\imath} \varsigma)$.

${ }^{181}$ Entendo que, segundo Filipe, ficar-lhe-ia mais barato pagar a Demóstenes do que equipar as suas trirremes.

${ }^{182}$ Referência ao cerco (falhado) de Bizâncio por Filipe em 340 a.C.

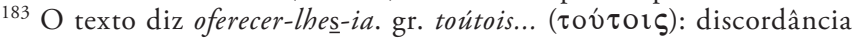
sintáctica. Talvez seja caso de emendar para o sing. toútō ${ }_{i}(\tau o v ́ \tau \omega)$, como, de resto, a seguir. 
como contra a acrópole, a muralha, os arsenais navais ou o fosso, mas admiro a sua coragem e felicito a cidade por possuir um tal cidadão. Quanto aos outros, assim que deixasse de ter necessidade deles, de muito bom grado os eliminaria, mas no que toca a este, antes queria tê-lo aqui comigo, mais do que a cavalaria dos Ilírios ou dos Tribalos e toda a tropa mercenária, pois considero o poder de persuasáo da palavra e o peso da mente em nada inferior à força das armas."

35. Assim falou Filipe a Parménion, e idênticas palavras me disse também a mim. E quando Diopites e a sua frota partiram de Atenas, eu fiquei muito preocupado, mas Filipe disse-me, sorrindo: "Estás com medo do que nos possa fazer um general ateniense ou um soldado? Antes de mais, para mim, as trirremes, o Pireu e os arsenais são bagatelas e ninharias. Sim, que me poderão fazer homens que celebram as Dionisiacas e passam o tempo em festins e em danças? Se não houvesse entre os Atenienses um Demóstenes, tomariamos a cidade mais facilmente do que [vencemos] os Tebanos ou os Tessálios, por meio do engano, da violência, da surpresa ou do dinheiro. Presentemente, porém, esse único homem está vigilante, acorre a todas as emergências, segue os nossos movimentos e faz frente às nossas estratégias. Não procedemos a uma táctica, não tomamos uma iniciativa nem traçamos um plano, sem que ele se aperceba; enfim, o homem é um [autêntico] obstáculo, um baluarte que nos impede de tomar tudo à nossa passagem. Se dependesse apenas dele, não teriamos tomado Anfípolis, não nos teríamos apoderado de Olinto, da Fócida $e$ das Termópilas e não seríamos agora senhores do Quersoneso e das terras à volta do Helesponto...

36. “... Ele estimula os seus concidadãos apáticos e adormecidos como que por efeito da mandrágora, usando a sua franqueza de linguagem como uma incisão e uma cauterização ${ }^{184}$ na sua indiferença, pouco se preocupando em lhes agradar. Além disso, transfere os recursos financeiros das representaçóes teatrais para as tropas; reforma, através das leis de equipamento naval, uma marinha quase completamente arruinada pela desorganizaçâo; desperta a honra da cidade, de há muito perdida devido à procura da drac-

184 "incisão e uma cauterização", termos médicos (p. ex., Hipócrates, Das Articulaçóes, 828). 
$m a^{185}$ e do trióbolo, tentando reconduzir os seus concidadãos, de há muito prostrados, ao nível dos seus antepassados e à imitação dos feitos [cometidos] em Maratona e em Salamina; institui alianças e confederaçóes helénicas. Não é possivel passar-lhe despercebido, nem enganá-lo, nem comprá-lo, tal como o rei dos Persas não conseguiu comprar o famoso Aristides...

37. “... Portanto, ó Antipatro, devemos temer este homem mais do que todas as trirremes e todas as expediçóes navais. De facto, aquilo que Temistocles e Péricles foram outrora para os Atenienses, Demóstenes é-o actualmente, pois rivaliza com Temistocles em inteligência e com Péricles em sensatez. Conquistou para estes, por the terem dado ouvidos, a Eubeia, Mégara, a regiäo do Helesponto e a Beócia. Procedem muito bem ${ }^{186}$ os Atenienses - continuou Filipe -, ao nomearem generais Cares, Diopites, Próxeno e outros que tais, mantendo Demóstenes dentro [da cidade], na tribuna. É que, se eles tivessem nomeado esse homem senhor dos armamentos, dos navios, das tropas, das acçóes oportunas e dos dinheiros, desconfio bem que ele já me tivesse disputado a própria Macedónia, ele que agora, combatendo-nos somente por decretos, nos cerca por todos os lados, nos surpreende, descobre recursos, envia armadas, reúne forças e nos defronta."

38. Eram mais ou menos deste teor as palavras que nesse tempo e em muitas ocasióes Filipe me dizia acerca desse homem, considerando como um dos benefícios da sorte o facto de Demóstenes náo ser general, ele, cujos discursos, lançados de Atenas, quais aríetes ou catapultas, abalavam e perturbavam os seus planos. Por exemplo, a respeito [da batalha] de Queroneia ${ }^{187}$, nem mesmo depois da vitória deixava de nos dizer até que ponto esse homem constituía um perigo para nós. $\mathrm{Na}$ verdade — dizia ele —, "apesar de, contra todas as expectati-

185 Os advogados públicos recebiam uma dracma por sessão, e cada membro do júri apenas três óbolos, ou seja, meia dracma, mesmo assim um precioso subsídio contra a pobreza extrema... NOTA a despropósito: Desde os tempos da velha... e moderna, moeda grega, a dracma, que se lia nas cotaçốes a expressão dracma grego. Ora, esta palavra foi sempre do género feminino (excepto em ingl.). Actualmente, volta a falar-se de $\underline{o}$ dracma (!)... para vergonha de $\underline{a}$ peseta, $\underline{a}$ libra, $\underline{a}$ lira...

186 "Procedem muito bem"... do ponto de vista de Filipe, é claro...

187 Queroneia era a cidade mais ao norte da Beócia. Foi nessa região que, em 338 a.C., Filipe derrotou os Atenienses e os Tebanos. 
vas, e devido à incompetência dos generais e à indisciplina dos soldados, e também por um estranha viragem da sorte, que tantas vezes colaborou connosco, termos conseguido tantos e tão grandes triunfos, nesse único dia Demóstenes teria posto em risco o meu reino e a minha vida, pois tinha unido num só corpo as cidades mais importantes e tinha reunido todo o potencial [guerreiro] da Grécia, forçando a entrar na luta, além dos Atenienses, os Tebanos $e$ os outros Beócios, os Corintios, os Eubeus, os Megarenses, bem como as maiores potências da Grécia, náo me permitindo sequer penetrar no interior da Atica."

39. Eram mais ou menos deste teor as palavras que continuamente dizia a respeito de Demóstenes. E àqueles que diziam que ele tinha um grande adversário no povo ateniense, respondeu: "Para mim, o único adversário é Demóstenes. Se os Atenienses não tivessem Demóstenes, seriam para mim como uns Enianos ${ }^{188}$ ou uns Tessálios." Sempre que Filipe enviava embaixadores às [diversas] cidades, se a cidade de Atenas lhes contrapunha quaisquer outros oradores a essa sua embaixada, rejubilava como se já tivesse vencido, mas quando lhe aparecia Demóstenes, dizia: "É em vão que lhes opomos a nossa delegação, ${ }^{189}$ uma vez que contra os discursos de Demóstenes não é possivel 'erguer o troféu'."

40. Assim falava Filipe. Mas, por Zeus!, achas tu, porventura, ó Árquias, que eu, que sou muitíssimo inferior [a Filipe], capturaria um tal homem para o conduzir, como a um boi, para o sacrifício, ou, pelo contrário, faria dele um conselheiro em assuntos gregos e em matéria respeitante a todo o meu reino? $\mathrm{Na}$ verdade, desde há muito que eu tinha uma certa admiração por ele, devido à sua própria acção política, mas ainda mais devido ao testemunho de Aristóteles. Este não parava de dizer a Alexandre e a nós, que, de entre tantos dos que haviam sido seus discípulos, nunca admirou nenhum tanto como a ele, pela grandeza do seu carácter e pela persistência no seu desenvolvimento, pela sua gravidade, rapidez [de raciocínio], liberdade de expressão e firmeza de espírito.

${ }^{188}$ Enianos, habitantes de Enia (Aineia, Aǐveı $\alpha$ ), cidade da Macedónia. Filipe exemplifica com dois povos que não lhe ofereciam qualquer dificuldade.

${ }^{189} \mathrm{O}$ editor da "Loeb" coloca aqui o início do $\$ 40$. Na verdade, não fica bem cortar desta maneira uma justificação do que é dito imediatamente antes. 
41. "Vós, porém - acrescentou Filipe —, fazeis dele o mesmo conceito que a respeito de um Eubulo, um Frinon ou um Filócrates, e então tentais seduzir também Demóstenes por meio de presentes, e logo ele, um homem que gastou a fortuna paterna em prol dos Atenienses, dando aos necessitados a titulo particular e à cidade a título público. Será que andais iludidos a ponto de cuidardes que intimidarieis um homem que decidiu expor a sua vida às vicissitudes imprevisiveis da sua Pátria e ficais furiosos quando ele repreende os vossos actos, ele que náo se submete nem mesmo à Assembleia do Povo de Atenas? Vós não vos apercebeis continuou Filipe - que ele faz politica por amor da sua Pátria e que se entrega à governação como um exercício de Filosofia?!"

42. Por isso é que eu, ó Árquias, desejava ardentemente tê-lo junto de mim e ouvi-lo exprimir a opiniáo que porventura ele tivesse sobre a situação actual, e, em caso de necessidade, e depois de me afastar dos bajuladores que estão continuamente à minha volta, ouvir a palavra de alguém sincero e de opiniáo livre e aproveitar o conselho de um homem amigo da verdade. Além disso, seria justo recordar-lhe a ingratidão desses tais Atenienses, em defesa dos quais ele expusera toda a sua vida, quando poderia ganhar amigos mais gratos e mais seguros.

ÁRQUIAS - Quanto às outras coisas, ó rei, talvez pudesses consegui-las, mas estas tuas [últimas] palavras ${ }^{190}$ di-las-ias em vão, a tal ponto ele era perdidamente 'filateniense'191.

ANTÍPATRO - Assim é, ó Árquias. Que mais poderíamos dizer?... Mas... como é que ele morreu?

43. ÁRQUIAS - Parece-me, ó rei, que vais ficar ainda mais admirado. Na verdade, nós, ainda sob a impressão visual da cena, não diferimos mesmo nada, em espanto e incredulidade, de quando a ela estávamos a assistir ${ }^{192}$. Realmente, parece que ele já desde há muito que tinha tomado uma decisão sobre o

190 “estas tuas [últimas] palavras”: refere-se à ingratidão dos Atenienses, porquanto, como se diz logo a seguir, Demóstenes era incondicionalmente um defensor de Atenas, um patriota radical.

191 'filateniense': Entendi verter fielmente o composto gr. philathènaîos ( $\varphi \imath \lambda \alpha \theta \eta \nu \alpha \hat{\imath} о \varsigma)$, certamente não registado nos dicionários.

${ }^{192} \mathrm{O}$ texto dos mss. é, à primeira vista, confuso, e por isso têm sido propostas diversas emendas. Entendi "afrontar" a lição dos mss.: O part.

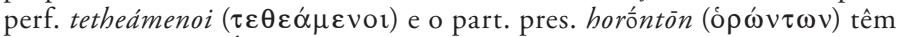
o mesmo sujeito: Árquias e os seus acompanhantes, os quais, ainda sob 
seu derradeiro dia. Os próprios preparativos o comprovam. De facto, estava sentado no interior do templo, e foi em vão que utilizámos os nossos argumentos dos dias precedentes.

ANTÍPATRO - E quais eram esses vossos argumentos?

ÁRQUIAS - Eu propunha-lhe muitas ofertas humanitárias e prometia-lhe misericórdia da tua parte... sem no entanto a esperar — na verdade, eu não sabia, julgava que tu estavas furioso com o homem - , mas por considerar esse procedimento útil para o persuadir.

ANTÍPATRO - Mas como é que ele recebeu as tuas palavras? Não me escondas nada, pois eu muito gostaria de entâo lá estar presente e ouvir com os meus próprios ouvidos. Portanto, não me omitas nada. Realmente, não é coisa de somenos importância conhecer a índole de um homem nobre perto do fim da sua vida, se se revelou fraco e frouxo, ou se manteve sempre indomável a altivez da sua alma.

44. ÁRQUIAS - O homem não se acobardou mesmo nada. Que digo eu? Sorrindo brandamente e troçando do meu primeiro modo de vida ${ }^{193}$, disse que eu era um actor nada convincente das tuas mentiras.

ANTÍPATRO - Terá sido porventura por não acreditar nas tuas promessas que ele lançou fora a sua alma?194

ÁRQUIAS - Nada disso. Se escutares o resto [da história], não acharás que foi só por não acreditar. Mas, ó rei, já que me ordenas que fale, Demóstenes disse: "Para os Macedónios, não há perjúrio nem nada de anormal, desde que capturem Demóstenes como se fosse Anfipolis, ou Olinto ou Oropo." E disse mais coisas deste género. Sim, que eu tinha levado comigo escribas, para que as suas palavras ficassem registadas.

"Ó Árquias - continuou Demóstenes —, não é por ter medo da tortura ou da morte que eu não me apresentaria diante de Antípatro, mas, se o que dizes é verdade, maior cuidado devo ter, para não dever a minha vida a um generoso presente de Antipatro e para não desertar das fileiras em que militei, mudando-me das fileiras helénicas para as macedónicas...

a impressão visual da cena, estavam tão espantados e incrédulos como quando a ela estavam a assistir.

193 Árquias tinha sido actor trágico.

194 "lançou fora a sua alma", trad. literal = "pôs termo à vida". 
45. “... Realmente, ó Árquias, seria para mim uma honra continuar a viver, se quem tal honra me desse fossem o Pireu, a trirreme que eu ofereci, a muralha e o fosso, que eu reconstrui a expensas próprias, a tribo ${ }^{195}$ Pandiónide, da qual fui corego ${ }^{196}$ voluntário, ou Sólon, e Drácon, e a franqueza de linguagem na tribuna, e o Povo livre, e os decretos militares, e as leis trierárquicas ${ }^{197}, e$ as virtudes dos nossos antepassados, e os troféus ${ }^{198}$, e o afecto dos meus concidadãos, que muitas vezes me coroaram, e [finalmente] o poderio dos Gregos, que eu até este momento tenho eu preservado. Mas uma vida que fica a dever-se a um acto de piedade é coisa humilhante, mas já é tolerável a piedade dos meus compatriotas, alguns dos quais eu libertei do cativeiro, ou dos pais a cujas filhas eu ofereci o dote, ou daqueles cujas dividas eu liquidei...

46. “... Mas se não é o poder das ilhas ${ }^{199}$ que me salva, nem o mar, rogo aqui a este Posidon, a este altar e às leis sagradas que me salvem. E se Posidon - continuou - não for capaz de preservar o direito de asilo do seu templo e náo se envergonhar de entregar Demóstenes a Árquias, antes quero morrer. Antipatro náo será por nós ${ }^{200}$ adulado, no lugar deste deus. Ser-me-ia possivel ter macedónios mais meus amigos que os atenienses, e estar neste momento a compartilhar a vossa boa sorte, se me tivesse posto do lado de Calimedonte, de Piteas e de Demades. Também poderia, embora tardiamente, alterar o meu destino, caso não tivesse respeito pelas filhas de Erecteu e por Codro ${ }^{201}$. Pelo contrário, não decidi mudar de campo, quando a divindade ${ }^{202}$ nos abandonou.

${ }^{195}$ As tribos, em número de 10, correspondiam mais ou menos - guardadas as devidas proporções territoriais - aos nossos distritos, e eram, por sua vez, subdivididas em demos, 10 por cada tribo...

196 Normalmente, os coregos eram indivíduos ricos escolhidos para suportarem certas despesas públicas (representaçôes dramáticas, festivais, equipamento naval,,,). O mérito de Demóstenes consistiu em se constituir voluntário para esse cargo... e despesa.

197 "leis trierárquicas", relativas ao equipamento de trirremes.

198 Os troféus, gr. trópaia $(\tau \rho o ́ \pi \alpha \iota \alpha)$ eram monumentos triunfais comemorativos de uma vitória.

199 "poder das ilhas", referência à liga ou confederação de estados insulares aliados de Atenas...

200 “nós", plural majestático.

${ }^{201}$ As sete filhas de Erecteu (rei de Atenas) e Codro (outro rei de Atenas) sacrificaram as sua próprias vidas para salvarem a cidade, na sequência de um oráculo...

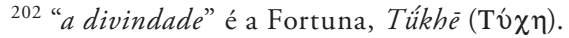


Na verdade, a morte é um bom refúgio para uma pessoa ficar ao abrigo de qualquer desonra. Pois agora, ó Árquias, em tudo o que depender de mim, não desonrarei Atenas, caso escolhesse conscientemente a escravidão e abandonasse o mais belo epitáfio: a liberdade...

47. “... Mas - continuou Demóstenes - éjusto recordar-te, de uma das nossas tragédias, este venerando passo:

\| Então ela, moribunda,
tomou muita precauçấo $\|$ pra cair com dignidade ${ }^{203}$.

"Se este foi o procedimento de uma jovem, deveria Demóstenes preferir a vida a uma morte digna, sem consideração pelas obras de Xenócrates e de Platão sobre a imortalidade [da alma]?"

Disse ainda algumas palavras bem amargas, em que se insurgia contra aqueles que a boa sorte torna insolentes... Mas... que mais devo acrescentar? Por fim, como eu ora lhe suplicasse, ora o ameaçasse, misturando a musa branda com a musa dura, ele disse: "Eu, se fosse Árquias, deixar-me-ia convencer por esses argumentos... mas, como sou Demóstenes, perdoa-me, meu caro, por eu não ser de carácter desonesto."

48. Nesse momento, e só nesse momento, pensei em arrancá-lo dali à força. Ele, porém, tendo-se apercebido disso, sorriu abertamente e, voltando-se para o deus, disse: "Parece que Árquias considera como forças e refúgios para as vidas humanas somente as armas, as trirremes, as muralhas e os exércitos, mas menospreza o meu 'equipamento ${ }^{204}$, que os Ilírios, os Tribalos e os Macedónios náo poderiam vencer e que é mais forte que a nossa muralha de madeira ${ }^{205}$, que o deus declarou inexpugnável.

${ }^{203}$ Eurípides, Hécuba, 568-369. Refere-se à morte de Políxena. Nos Lusíadas, III, 131, 1, Camóes adapta a forma como Policena, rimando com condena e serena. Na verdade a adaptação "canónica", com acentuação proparoxítona, era muito incómoda para o decassílabo.

${ }^{204}$ Aqui, paraskeué ( $\left.\pi \alpha \rho \alpha \sigma \kappa \varepsilon v \eta ́\right)$ refere-se, num primeiro nivel, ao tipo de equipamento mencionado imediatamente atrás, mas o sentido último é "equipamento oratório", que era, afinal, a "arma" mais poderosa de Demóstenes.

${ }^{205}$ A "muralha de madeira" a que o oráculo do deus (Apolo) se referia eram os navios atenienses. O texto do oráculo está transcrito em Heródoto, VII, 141. 
Foi com essa 'precauçãon" que eu sempre exerci corajosamente a minha acçâo politica, tal como corajosa era a minha audácia contra os Macedónios, sem querer saber para nada, nesse tempo, de Euctémon, nem de Aristogíton, nem de Piteas, nem Calimedonte, nem de Filipe e agora das manobras de Árquias."

49. Ditas estas palavras, acrescentou: "Não ponhas sobre mim a tua mão. Na verdade, no que depender de mim, o templo não sofrerá qualquer profanação, pois eu, depois de saudar o deus, seguir-te-ei voluntariamente." Aí eu fiquei na expectativa e, ao vê-lo levar a mão à boca, entendi que não era senão para saudar ${ }^{207}$ o deus.

ANTÍPATRO - Então era para quê?

ÁRQUIAS - Mais tarde descobrimos, através de torturas sobre uma criada, que ele há muito que tinha guardado um veneno, a fim de obter a liberdade, separando a alma do corpo. E de facto, ainda não tinha ultrapassado a soleira do templo, quando, olhando para mim, disse: "Leva este 208 a Antipatro, mas não levarás Demóstenes, não, [juro] pelos..." Pareceu-me que ia acrescentar "... que cairam em Maratona”.

50. Então, dizendo-nos adeus, soltou o espírito.

É este, ó rei, o resultado que posso trazer-te do cerco de... Demóstenes.

ANTÍPATRO - Esse procedimento, ó Árquias, é mesmo digno de Demóstenes. Oh que espírito indomável e bem-aventurado! ${ }^{209}$ Que corajosa resolução a sua! Que previdência política, essa de ter à máo o garante fiel da liberdade! Mas partiu, a fim de ter, nas ilhas dos bem-aventurados, a vida chamada dos heróis, ou então seguiu o caminho para

${ }^{206}$ Aqui, prónoia ( $\pi \rho$ óvol $\alpha$ ), “previdência”, “precaução”, é um quase-sinónimo do precedente paraskeuế ( $\pi \alpha \rho \alpha \sigma \kappa \varepsilon v \eta ́)$. Poderíamos traduzi-lo por "arma de reserva"... sempre a arma oratória...

$207 \mathrm{O}$ verbo proskünéo ( $\pi \rho \circ \sigma \kappa v \vee \varepsilon ́ \omega)$ significa "prostrar-se em sinal de adoração e saudação", implicando o gesto de levar a mão à boca, simbolizando um beijo dado à divindade.

208 "este", acusat. masc. toûton ( $\tau$ o v̂ $\tau$ ov), certamente acompanhado do gesto indicando o seu corpo... Até se esperaria o neutro tồto ( $\tau 0 \hat{v} \tau o$ ), "isto", "esta coisa" (o corpo, é claro).

${ }^{209}$ A forma (genit.) makarias ( $\left.\mu \alpha \kappa \alpha \rho i \alpha \varsigma\right)$ também pode ser interpretada como subst.: "Oh que espírito indomável! Oh que bem-aventurança!". De toda a maneira, como se vê a seguir, trata-se de uma referência à zona do Hades reservada aos bem-aventurados. 
o céu, que se julga ser o [caminho] das almas, a fim de ser um génio tutelar junto de Zeus Libertador. Quanto ao seu corpo, enviá-lo-emos para Atenas, como oferenda mais preciosa para essa terra do que os caídos em Maratona. 
Alcíone ou Metamorfoses 
(Página deixada propositadamente em branco) 


\section{INTRODUÇẤO}

Este curto diálogo, em que o Autor põe Sócrates a conversar com o seu grande amigo e discípulo Querefonte, foi-nos transmitido em manuscritos que contêm obras de Luciano, mas também de Platão, pelo que tem sido atribuído a um destes escritores. A crítica moderna, porém, nega qualquer destas autorias. No caso da atribuição a Platão, ela é altamente inverosímil, pelo facto de, no $\$ 8$, se fazer referência a duas esposas de Sócrates, Xantipa e Mirto, situação que não se vê na obra de Platáo, para o qual Xantipa é a única esposa de Sócrates.

Por outro lado, o diálogo, em si mesmo, náo parece (mesmo nada!) ter saído da imaginação de Platão, que conhecia bem Querefonte e, por isso, não o apresentaria com toda aquela ignorância a respeito do mito de Alcíone.

No que respeita à autoria de Luciano, o texto, em si mesmo, náo proíbe essa atribuição. Poderia (mera hipótese sem fundamento!) ver-se este diálogo como um exercício escolar da juventude de Luciano sobre um tema mitológico, caso em que o Autor, com a sua liberdade literária, simplesmente imagina, como suporte da explicação, a pergunta inicial, mas também inverosímil, de Querefonte (\$1): "Que voz é esta, ó Sócrates, que chega até nós, vinda dos lados da praia e daquele promontório? Que voz tão doce para os ouvidos! Quem será o animal que emite esse som? Na verdade, os seres que vivem na água são mesmo mudos."

A resposta e explicação de Sócrates estaria mais ou menos dentro dos processos de raciocínio do nosso conhecido filósofo, pelo que o Autor do diálogo poderia ser qualquer imitador do estilo literário de Platão e da figura de Sócrates.

Segundo M. D. Macleod (“Loeb”, VIII, p. 305), a inclusão de Alcione ou Das Metamorfoses entre os manuscritos de Luciano dever-se-ia precisamente ao título alternativo, Das Metamorfoses, por associação com o outro título de $O$ Burro, de Luciano: As Metamorfoses de Lúcio de Patras. Não convence...

No que respeita à "justificação" do mito, ou seja, no que toca à possibilidade de haver transformações de pessoas em aves e outras metamorfoses do género, diz Sócrates que há fenómenos muito mais estranhos, e que, no entanto, estão mesmo perante os nossos olhos... além de que à divindade e à Natureza nada é impossível...

Se a obra fosse de Luciano, poderíamos entrever aqui uma certa crítica à ingenuidade com que alguns acreditam na Mitologia... 
(Página deixada propositadamente em branco) 


\section{Alcíone ou Metamorfoses}

1. QUEREFONTE - Que voz é esta, ó Sócrates, que chega até nós, vinda dos lados da praia e daquele promontório? Que voz tão doce para os ouvidos! Quem será o animal que emite esse som? Na verdade, os seres que vivem na água são mesmo mudos.

SÓCRATES - Trata-se, ó Querefonte, de uma ave marinha chamada alcione, muito plangente e lacrimosa, a respeito da qual os homens contam uma fábula. Dizem que ela era outrora uma mulher, filha de Éolo, este filho de Hélen, e que chorava de saudade pelo seu falecido marido, [de nome] Ceíce de Tráqui ${ }^{210}$, filho do astro Eósforo ${ }^{211}$, formoso filho de um formoso pai; [diz-se] que, mais tarde, tendo ganho asas graças á vontade divina, sobrevoa os mares como uma ave, em busca do esposo, depois de ter vagueado por toda a terra sem poder achá-lo.

2. QUEREFONTE - Será o alcião, essa ave de que falas? Ainda nunca antes tinha ouvido a sua voz, e por isso ela me chegou aos ouvidos de um modo realmente estranho. De facto, esse animal emite um som verdadeiramente plangente. Mas... de que tamanho é ele, ó Sócrates?

SÓCRATES - Nâo muito grande. Em todo o caso, é objecto de grande estima por parte dos deuses, devido ao seu amor conjugal. Na verdade, por altura da sua nidificação, o mundo conhece os dias chamados "alciónides", que se distinguem pelo bom tempo em pleno Inverno ${ }^{212}$, e hoje é um desses dias mais que todos. Não vês como o céu está límpido e como o mar está completamente chão e calmo, semelhante, por assim dizer, a um espelho?

QUEREFONTE - Dizes bem. Sim, o dia de hoje parece ser mesmo um dia "alciónide", e ontem estava igual a hoje... Mas, pelos deuses!, como se pode alguma vez, ó Sócrates, acreditar nessas histórias da Antiguidade... que mulheres foram

210 "Tráquis", cidade da Tessália.

211 "Eósforo" (também Heósforo), gr. Heōsphóros ( $\left.\mathrm{E} \omega \sigma \varphi o_{\rho} \rho \varsigma\right)$, lit. ${ }^{\text {te }}$ "que traz a Aurora" (Héōs, "E $\omega \varsigma$ ), "estrela matutina”. Corresponde, em lat., a Lucifer.

${ }^{212}$ Este bom tempo faz-se sentir sete dias antes e sete dias depois do dolstício do Inverno. 
originadas de aves, ou aves [originadas] de mulheres? Realmente, fenómenos desses afiguram-se-me completamente impossíveis.

3. SÓCRATES - Meu amigo Querefonte, nós fazemos figura de juízes completamente míopes sobre o que é possível ou impossível. Na verdade, nós emitimos as nossas opiniôes segundo a capacidade humana, a qual é incapaz de conhecer, de acreditar e de observar. Assim, muitas coisas fáceis parecem-nos difíceis, muitas coisas atingíveis parecem-nos inatingíveis, muitas vezes devido à nossa inexperiência, e muitas outras vezes pela infantilidade das nossas inteligências. Sim, em boa verdade, todo o ser humano parece infantil, até mesmo o muito velho, uma vez que o nosso tempo de vida é muitíssimo curto e de curta duração comparado com toda a eternidade. Então como é que nós, pessoas que desconhecem os poderes dos deuses e de outras entidades divinas, bem como todas as forças da Natureza, poderíamos dizer qual destes fenómenos é possível ou impossível? Viste, ó Querefonte, como era a invernia ainda anteontem? Ainda agora nos assalta um sentimento de terror, só de lembrarmos aqueles relâmpagos, os trovôes e a grande fúria dos ventos, que até cuidaríamos que toda a terra habitada iria desmoronar-se.

4. Passado pouco tempo, porém, eis que sobreveio uma situação de bom tempo, que durou até ao dia de hoje. Portanto, qual das duas coisas julgas maior e mais trabalhosa: transformar aquela tempestade irresistível e aquela perturbação neste bom tempo e reconduzir todo o mundo ao estado de serenidade, ou fazer com que uma figura de mulher se transforme numa figura de ave? Num caso como este último, até as nossas criancinhas, que sabem moldar, pegam em barro ou em cera e, a partir do mesmo material, facilmente e muitas vezes modelam diversos tipos de formas. Ora, para a divindade, que possui uma grande superioridade, incomparável em relação aos nossos poderes, todas as acçóes desse género deveriam ser extremamente fáceis. Sim, quantas vezes é que tu julgas que o céu é maior que tu? Serias capaz de dizer?

5. QUEREFONTE - Qual dos homens, ó Sócrates, seria capaz de calcular ou de exprimir uma coisa desse tipo? $\mathrm{Na}$ verdade, não está ao nosso alcance dizê-lo sequer.

SÓCRATES - Mas não observamos nós, ao compararmos seres humanos uns com os outros, que existem grandes 
disparidades no que respeita quer às suas capacidades, quer às suas incapacidades? $\mathrm{Na}$ verdade, a idade dos homens, quando comparada com a das crianças de muito tenra idade... com uns cinco ou dez anos, apresenta uma diferença espantosa quanto a capacidades e incapacidades em quase todas as actividades da vida, realizadas não só através destas nossas artes tão multifacetadas, mas também por meio da força física e mental. Realmente, tais actividades nem sequer parecem susceptíveis de ocorrer às crianças, como disse, muito novas.

6. Além disso, o grau de força de um único homem já completamente desenvolvido apresenta uma superioridade incalculável comparada com a das crianças. De facto, um único homem poderia facilmente vencer muitos milhares destas. É que, por sua própria natureza, a idade completamente carente, digamos assim, de tudo e desprovida de recursos, acompanha logo de início os seres humanos. Ora, quando, como parece, um ser humano se diferencia tanto de outro ser humano, que pensaremos nós que todo o céu, comparado com as nossas capacidades, pareceria àqueles que contemplam tais fenómenos? Portanto, talvez pareça para muitos plausível que a grandeza do Universo apresente tanta superioridade em comparaçáo com a estatura de Sócrates ou de Querefonte, como a capacidade, a compreensáo e a inteligência do Universo diferem em idêntica proporçáo da nossa condiçáo.

7. Ora, muitas coisas tidas por impossíveis para mim, para ti e para muitos outros, são extremamente fáceis para outros. De facto, é mais difícil tocar flauta para os que não aprenderam, ou ler e escrever para os ignorantes da técnica da escrita (enquanto não aprenderem tais coisas), do que transformar aves em mulheres ou mulheres em aves. A Natureza, ao depositar no favo um animal sem patas e sem asas, fornece-lhe patas e asas e enfeita-o com muita e bela variedade geral de cores, e forma uma abelha sábia, fabricante do divino mel, e, de ovos mudos e sem alma, forma muitas espécies de animais, tanto aéreos, como terrestres, como aquáticos, utilizando, no dizer de alguns, artes sagradas do grande Éter.

8. Ora, sendo enormes as capacidades dos imortais, e sendo nós mortais, infinitamente pequeninos e incapazes de ver 
quer as coisas grandes, quer as pequenas, mas perplexos com a maior parte dos fenómenos que acontecem à nossa volta, não poderíamos falar com segurança de alcíones ou de rouxinóis. A fama dessas lendas, que os nossos pais nos transmitiram e nós transmitimos aos nossos filhos, ó ave cantora de prantos, também eu transmitirei, falando dos teus hinos, e muitas vezes cantarei para as minhas esposas Xantipa e Mirto ${ }^{213}$, o teu amor piedoso e marital, narrando, entre outras coisas, a grande honra que tu recebeste da parte dos deuses. Será que também tu, ó Querefonte, estás disposto a fazer algo semelhante?

QUEREFONTE - É justo, ó Sócrates, e o que tu disseste até contém uma dupla exortação, respeitante às [mútuas] relaçôes entre esposas e maridos.

SÓCRATES - Nesse caso, é tempo de nos despedirmos de Alcíone e irmos andando de Falero a caminho da cidade. QUEREFONTE - Muito bem. Façamos assim.

213 A esposa “canónica” de Sócrates é Xantipa, mas, segundo certas fontes, Sócrates assumira a protecção (marital ou... equivalente) de Mirto, neta de Aristides-o-Justo. O Autor desta obra (que parece não ser Luciano) aproveita o aspecto subtilmente "picante" da versão da segunda esposa de Sócrates. 
A Gota 
(Página deixada propositadamente em branco) 


\section{INTRODUÇÁO}

A autoria desta pequena jóia trágico-lírica, com algumas "pitadas" de humor, tem sido negada a Luciano, em boa parte pelo facto de vir acompanhada de uma outra, Ocipode ["O Homem dos Pés Ligeiros"], que parece constituir a sequência de $A$ Gota, mas que lhe é muito inferior em todos os aspectos, nomeadamente na linguagem e na métrica. De facto, náo imaginamos que Luciano, depois de escrever a bela peça que é $A$ Gota (se é ele seu autor), como que tivesse perdido as suas grandes qualidades nesta espécie de sequência. Enfim, não há motivo para negar a Luciano a autoria desta obra. Quanto à autoria de Ocípode, aceitamos a opiniáo geral de que se trata de uma obra posterior a Luciano, talvez de época bizantina, eventualmente inspirada em $A$ Gota, da qual se apresenta como uma sequência natural, com a sua conclusão lógica: Um vigoroso jovem que se gabava da sua saúde inquebrável, acaba por sofrer o castigo da divindade intratável, que é a Gota. Para mais informação, veja-se a Introdução a Ocípode.

NOTA: Como faço em traduçóes de passos em verso (grego), também aqui tentei dar uma versão em verso português, que, naturalmente, só tem de comum com a métrica grega o facto de ser constituída por elementos regularmente repetidos. Indico entre parênteses rectos [] o tipo de verso português, com uma cesura que, de algum modo, trenta sugerir a autêntica cesura dos versos gregos. 
(Página deixada propositadamente em branco) 


\section{A Gota}

PERSONAGENS:

O GOTOSO, CORO, A GOTA, MENSAGEIRO, MÉDICO, AS DORES

GOTOSO -7|| 7$.

Ó tu, de nome odioso $\|$ e dos deuses odiado, $\mathrm{Tu}$, Gota, rica em lamentos, || tu, a filha de Cocito. que nos recantos do Tártaro, \| de profunda escuridão, a Erínia Megera || de seu ventre fez nascer,

5 e em seu peito amamentou, || e a ti, cruel infante, em teus lábios destilou || também Alecto seu leite, Quem foi, de entre as divindades, || que te fez subir à luz, maldito ser? Tu vieste \| pra ser dos homens flagelo. Se depois da nossa morte || se segue para os mortais

10 a punição dos seus crimes || cá na terra cometidos, não se deviam punir, || na morada de Plutão, nem Tântalo pela sede, || nem Ixíon pela roda mas simplesmente entregar || todos esses criminosos

15 às tuas horrendas dores, $\|$ de articulaçôes tormento. Oh! Como está o meu corpo \| ressequido e sofredor, das pontas das minhas mãos \| até às pontas dos pés! Um humor muito funesto \| e um suco amargo da bílis tornam o respirar penoso, || entupindo-me os canais,

20 e, mantendo-os encerrados, || mais prolonga as minhas dores. Por estas minhas entranhas \| corre um mal abrasador, que, quais turbilhôes de chamas, $\|$ a carne ardente consome, dir-se-ia uma cratera || cheia do fogo do Etna, ou o estreito da Sicília, || de passo bem apertado,

25 que, batido pela onda || sem ter por onde escoar-se, em remoinhos se abate $\|$ contra as cavernas das rochas. E tu, ó morte insondável \| para todos os mortais, como é em váo que nós todos || invocamos teu socorro, ingenuamente embalados || numa esperança vazia!

\section{$\mathrm{CORO}-$}

30 No Dídimo, a Cíbele sagrado, os Frígios soltam gritos delirantes ao delicado Átis consagrados; e ao som do tocador da frígia trompa, do Tmolo montanhoso nas encostas, 
35 os Lídios soltam seus cantos de orgia;

e loucos por acçáo dos tamboretes, entoam o evoé os Coribantes, ao ritmo compassado dos Cretenses; e gravemente soltam as trombetas

40 o toque da batalha anunciando, Por isso, nós, ó Gota, teus devotos, da Primavera nas primeiras horas, nossos ritos chorosos celebramos,

45 agora que já estão todos os prados de verdejantes ervas florescentes, e por acçáo de Zéfiro e seu sopro as árvores ostentam tenras folhas, e quando junto às casas dos mortais

50 chilreia a andorinha desditosa, e quando toda a noite, nesses bosques, Átis, o rouxinol, com seus lamentos, suspira lacrimosa por seu Ítis.

\section{GOTOSO -}

Alívio das minhas dores, || ó minha terceira perna,

$55 \mathrm{Tu}$, bengala que o meu fado $\|$ me destinou, sê suporte do meu andar tremebundo, || sê o guia dos meus passos

e sê a marca segura \| para me firmar no chão.

Ergue já, ó infeliz, \| os teus membros deste leito, abandona-me esse tecto || escorado em fortes vigas;

60 dissipa desses teus olhos \| a nocturna e espessa bruma, e saindo porta fora, || virado prà luz do sol, aspira a suave brisa \| que traz um sopro sereno. Já brilha o décimo dia, || e junto a este outros cinco que estou encerrado em trevas, || da luz do sol arredado,

65 e num leito sem coberta || vou esfregando meu corpo. Mas o que a alma me pede, $\|$ e é todo o meu desejo, é que dirija meus passos $\|$ resolutos prà saída... só que o corpo preguiçoso || náo obedece a desejos. Mas mesmo assim, ó minha alma, \| desperta, pois sabes bem

70 que um homem pobre e gotoso, || se pretender deslocar-se, e fazê-lo não puder, || já está no rol dos defuntos.

73 Vamos então!... 
Quem são estes, que manejam $\|$ em duas mão ${ }^{214}$ seus cajados, de cabeça coroada || com folhas de sabugueiro?215

75 A qual dos deuses dedicam || o seu coro ritual? Será a ti, Febo Péan, || que eles prestam suas honras? Não estão, porém, coroados \| co' a folha do louro délfico. Ou será um hino a Baco, \| festivamente entoado? Mas não têm os cabelos $\|$ em folhas de hera envolvidos. 80 Quem sois vós, ó estrangeiros, || e de que terra viestes? Falai sem constrangimento, || fazei um discurso franco: Dizei, amigos, qual é || a deusa que vós cantais.

\section{CORO -}

E tu, que tal nos perguntas, $\|$ diz-nos quem és, donde vens. Como sugere o cajado \| e esse teu modo de andar, 85 vemos um iniciado $\|$ da divindade invencível.

\section{GOTOSO -}

Mas serei eu, porventura, || digno de tal divindade?

\section{CORO -}

Assim como Nereu nas salsas ondas com gotas que caíram lá do céu ${ }^{216}$, a Cíprica Afrodite alimentou,

90 assim criando a bela criatura; tal como junto às fontes de Oceano Tétis $^{217}$ de largas tetas aleitou Hera, de Zeus Olímpico consorte, a bela divindade de alvos braços;

95 também do alto da imortal cabeça o Crónida, o melhor de entre os Olímpicos,

${ }^{214} \mathrm{O}$ dual kheroîn $(\chi \varepsilon \rho o \hat{\imath} v)$ indica claramente o uso simultâneo de dois cajados ou bengalas.

${ }^{215} \mathrm{O}$ sabugueiro tem, entre outras, propriedades diuréticas, pelo que julgo que era usado no tratamento da gota, eliminando o excesso de ácido úrico. Daí que os pacientes aqui descritos viessem coroados com folhas de sabugueiro.

${ }^{216}$ Luciano opta pela versão, segundo a qual Afrodite foi gerada (não por Zeus e Díone), mas pela semente de Úrano, a quem Crono mutilara, e cujos órgáos deram origem à formosa deusa.

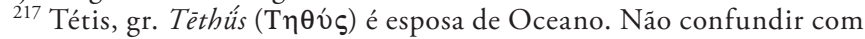

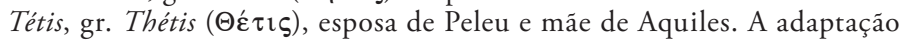
"canónica" ao port. produziu este... incómodo. 
brava figura de mulher gerou:

Atena, incitadora de combates;

a nossa venturosa divindade

100 o velho Ofíon em seus gordos braços

a deu primeiro à luz, quando cessou

do primitivo Caos a escuridáo

e a radiante Aurora despontou

e Hélio irradiou todo o seu brilho.

105 Então surgiu a poderosa Gota.

E quando do seu ventre te pariu

e então a Parca Cloto te lavou, eis que Úrano ${ }^{218}$ sorriu com todo o brilho,

o Éter trovejou mesmo sem nuvens,

110 e em suas 'tetas', de 'leite' abundantes,

o mui rico Plutão a 'amamentou'219.

\section{GOTOSO -}

Que ritos impóe a deusa || aos seus fiéis seguidores?

\section{CORO - 10|| $\mid 7$.}

Nosso fogoso sangue não vertemos \| dando golpes de punhal, nem enrolamos nossas cabeleiras \| do nosso pescoço à volta,

115 também não flagelamos nossas costas || com astrágalos ${ }^{220}$ sonantes,

nem comemos de touros carne crua \| que retalhamos em tiras.

Mas quando a delicada flor do ulmeiro || na Primavera desponta,

e o melro harmonioso nas ramagens || solta um canto variado,

então uma picada muito aguda || atinge os iniciados,

20 discreta e invisível, que penetra || nas profundezas dos membros,

no pé, joelho ou cótila ou nas vértebras, || ou nas ancas ou nas coxas,

218 Aqui confundem-se o céu, ouranós (ov̉ $\alpha$ ovós), e Úrano, Ouranós (Ov̉p $\alpha$ vós)... pai da Gota (v. nota supra).

219 'Tetas', 'leite' e 'amamentar', referidos a Plutão, só em sentido figurado... de alcance sexual (?).

${ }^{220}$ Trata-se de chicotes de couro armados de ossinhos... 
nas mãos, nas omoplatas ou nos braços, || nos cotovelos, nos pulsos,

corrói, devora, queima e domina, || e inflama, e massacra, até que enfim a deusa à dor ordena $\|$ que saia do paciente.

\section{GOTOSO -7|| 7$.}

125 Serei também porventura || eu um dos iniciados, sem disso me aperceber? || Pois mostra-te, ó divindade, ao suplicante benigna, || e entoarei com os mistes teus hinos e cantarei || dos gotosos a canção.

CORO - 10 .

Guarda silêncio e fica calmo, ó Éter!

130 Que todos os gotosos se recolham!

Ao seu altar já se dirige a deusa do leito amiga e em passo sustentado por um bordão... Pois viva a mais insigne das divindades! Vem a teus fiéis

135 benigna, e de rosto luminoso!

Concede às nossas dores rápido alívio, agora na estação primaveril.

\section{GOTA -7|| 7$.} mortais,

Quem há que não me conheça, || entre os terrenos a soberana das dores, || a invencível Podagra?

140 Nem o vapor dos incensos \|| tem força pra me acalmar, nem o sangue derramado \| sobre os altares em fogo, imagens,

nem o templo, onde pendentes $\|$ se encontram ricas fármacos,

a mim, que nem mesmo Péan $^{221} \|$ pode vencer com seus

ele que é lá no Olimpo $\|$ médico dos deuses todos,

145 nem de Febo o próprio filho, || o mui sabedor Asclépio. Logo que surgiu no mundo || a espécie dos humanos, todos têm a audácia $\|$ de meu poder destruir, sempre inventando processos $\|$ de novas drogas obter. Cada um experimenta || sua arte contra mim:

${ }^{221}$ Péan, velho deus da medicina (já de época micénica), mais tarde assimilado a Apolo. 
150 Esfregam-se com tanchagem ${ }^{222}$, || e usam também o aipo, ou então folhas de alface, \| ou beldroegas do prado, ou a folha do marroio, \| ou *hortelā-da-ribeira ${ }^{223}$, esfregam-me uns com urtigas, $\|$ ou co'a folha da consolda. outros usam a lentilha, \| que aos pântanos vão buscar,

155 ou pastinaga cozida, || ou folhas de pessegueiro, ou de meimendro, ou papoilas, $\|$ ou a casca da romá, ou cebola, ou alfavaca, $\|$ incenso, ou raiz do eléboro, fenacho junto com vinho, || girino, cola ou lentilha, ou a seiva do cipreste, $\|$ ou farinha de cevada,

160 folhas de couve cozidas, || ou entăo gesso de Paros, de cabra do monte estrume, \| ou excrementos humanos, farinha feita de fava, \| ou a flor da pedra de Assos ${ }^{224}$; Cozem sapos, musaranhos, || lagartixas e doninhas, cozinham râs e hienas, \| antílopes e raposas.

165 Qual dos metais não foi já $\|$ dos mortais exp’rimentado? Que poção não foi usada, \| ou seiva de qualquer árvore? Ossos de todos os bichos, \| bem como nervos e pele, gordura, sangue e medula, || urina, excrementos, leite, uns bebem este remédio, \|| repartido em quatro doses,

170 ou em oito, e a maioria \|| toma-o por sete vezes. Um tenta purificar-se || com uma droga sagrada, outro deixa-se burlar \| com encantos de impostores, a outro tolo um judeu || engana com seus feitiços, outro busca sua cura \| da deusa Círrane ${ }^{225}$ vinda.

$175 \mathrm{Eu}$ a estes todos digo \| que prossigam seus lamentos, e aos que usam de tais mezinhas $\|$ e atentam contra mim costumo corresponder $\|$ cada vez mais furiosa.

Mas aos que são mais sensatos $\|$ e não lutam contra mim mostro uma mente suave, \| torno-me benevolente.

180 Aquele que participa || nos meus mistérios sagrados aprende, pra começar, \|| a falar sensatamente, a todos ser agradável, $\|$ a dizer gentis palavras; esse é olhado por todos $\|$ com risos e com aplausos,

222 "tanchagem", plantaginácea vivaz e medicinal (dics.).

223 "hortelã-da-ribeira” é tradução muito insegura de gr. (acusat.)

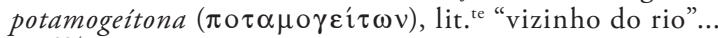

${ }^{224}$ Parece tratar-se de uma pedra calcárea com propriedades cáusticas...

${ }^{225}$ Círrane parece ser uma divindade-feiticeira da Cilícia. Luciano usa

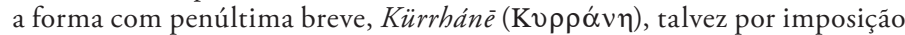

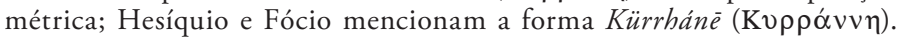
Neste último caso, a forma aportuguesada seria Cirrane. 
de outros.

sempre que vai para os banhos || transportado às costas

$185 \mathrm{Na}$ verdade, aquela Ate ${ }^{226}$, || de quem fala Homero, eu sou, que caminha sobre os homens \|| e tem leve andar de pés. Mas prà grande maioria || dos mortais eu sou chamada Podagra, que quer dizer, || 'a que apanha pelos pés'227. Mas vamos lá, todos vós, || mistes das minhas orgias, 190 com vossos hinos honrai \|| a divindade invencível.

CORO - 10 .

Virgem de coração diamantino, mui forte divindade, de alma dura, escuta a voz dos teus mortais devotos. Grande é o teu poder, Gota opulenta,

195 que até de Zeus o raio veloz teme, por quem tremem do mar profundo as ondas e treme o próprio Hades, rei dos mortos,

$\mathrm{Tu}$, que amas ligaduras e o leito, ${ }^{228}$ do andar traváo e de ossos o tormento, 200 que os pés queimas e mal tocas no chão que o piláo temes, e em noites de insónia abrasas o joelho e calcificas as juntas, e as pernas tornas cambas, 203b] e por isso mais curtas: Tu ó Gota!

\section{MENSAGEIRO - $7 \| 7$.}

204 Senhora, que aqui chegaste \| por teu pé bem oportuno. 205 escuta-me, pois te trago || uma nova nada fútil, discurso.

mas o facto, em si mesmo, \| concorda com o meu

Tal como tu me ordenaste, || eu, com passada mui lenta, corri todas as cidades, $\|$ visitei todas as casas,

${ }^{226}$ Ate é a personificação do erro, do engano, do embuste, aquela que induz os homens (e até... Zeus!) em erro; poisa seus leves pés sobre as cabeças dos mortais, sem que eles se apercebam. Neste passo, Luciano parece associá-la mais ao conceito de "desgraça”...

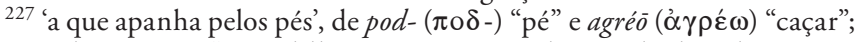
em sentido comum, "armadilha em que o animal é apanhado pelas patas".

${ }^{228}$ Os vv. 198-203 contêm epítetos cómicos de grande... comprimento, ao estilo aristofânico, que otrnaram difícil manter na tradução o mesmo número de versos. Assim, o v. assinalado como 203b deve ser "diluído" no verso precedente... 
procurando ver se alguém || não respeita o teu poder.

210 Entre aqueles que observei, || só vi almas conformadas, vencidas, Senhora minha, \| pela força dos teus braços. inaudita,

Dois, porém, de entre os mortais, \| com uma audácia

perante todos os povos $\|$ afirmavam e juravam

que o teu poder já não é || merecedor de homenagem,

215 mas que vão lançar-vos fora \| da existência dos mortais. Por isso, meu pé ligando || co’ apertadas ligaduras, corri em cinco jornadas || dois estádios de distância ${ }^{229}$.

GOTA -7|| 7$.

Como rápido voaste, || meu mais veloz mensageiro!

De que terra inacessível || suas fronteiras deixando,

220 aqui vens? Diz claramente, || pra que eu saiba sem demora.

MENSAGEIRO $-7 \|$

Primeiramente desci || cinco degraus de uma escada, com travessas de madeira || que, mal juntas, abanavam; depois vinha um pavimento || feito de terra batida, mas com duríssimos altos, || que feriam os meus passos.

225 Ultrapassada esta zona, || co' as solas dos pés doridas, enfiei por um caminho \| de calhaus pavimentado, de piso muito penoso, $\|$ pejado de agudas pedras. Depois dei com um caminho \| muito liso e deslizante: ao tentar seguir em frente, $\|$ a argila muito solta

230 impelia para trás || os meus fracos calcanhares.

Nesse caminho avançando, || um abundante suor todo o corpo me inundava $\|$ e me deixava esgotado ${ }^{230}$. Moído por todo o corpo, || eis que depois me recebe uma estrada muito larga, \| mas nem por isso segura.

235 De uma parte e de outra parte || me surgiam carruagens que me apressavam, forçavam, || impeliam-me a correr. Para aliviar um pouco \| o meu preguiçoso pé,

${ }^{229}$ A medida do estádio variava segundo as cidades. Em Atenas, o estádio tinha $184,98 \mathrm{~m}$, e em Olímpia $192,27 \mathrm{~m}$. Neste caso, interessa notar a "espantosa" velocidade de dois estádios em cinco dias... autêntica e vertiginosa velocidade de... tartaruga...

${ }^{230} \mathrm{O}$ v. 232 está nitidamente corrompido em todos os mss., pelo que deve tratar-se de leitura muito antiga; os editores tentam emendar... como podem (v. "Loeb”, VIII, p. 345. Naturalmente, a minha versão é problemática. 
segui ao lado da via, || por uma estreita berma, até que por mim passassem \| os carros de rodas rápidas, 240 pois sendo vosso devoto, || não posso correr veloz.

\section{GOTA - 7|| 7$.}

Não foi em vão, meu amigo, || que essa acção executaste muito bem executada. || Em paga desse teu zelo, vou conceder-te uma graça \|l de valor proporcional. Que grata ao teu coraçáo || seja esta minha dádiva:

245 Passarás estes três anos \| de dores aliviado... ${ }^{231}$ Mas vós, ó seres malditos || e dos deuses odiados, declarai-me ${ }^{232}$ quem sois vós, || de que gente descendeis, vós que ousais afrontar || o poderio de Podagra, cuja força nem o Crónida ${ }^{233}$ || é capaz de subjugar.

250 Falai, ó gente perversa. || Sim, pois eu já dominei grande parte dos heróis, || como os eruditos sabem. Príamo "de pés velozes"234, || afinal era gotoso; Aquiles, de Peleu filho, || morreu "de gota num pé”235; o herói Belerofonte || também suportou a gota ${ }^{236}$;

255 gotoso igualmente era \| Édipo ${ }^{237}$, o rei de Tebas; da família dos Pelópidas, || Plístenes era gotoso; gotoso era de Peante || o filho ${ }^{238}$, chefe de frota;

${ }^{231}$ Segue-se uma mudança de assunto: trata-se dos malditos médicos, seus inimigos...

232 "declarai-me"... “descendeis" não constam do texto: é só para "encher" o verso...

233 "Crónida", filho de Crono, ou seja, Zeus (cf. v. 195).

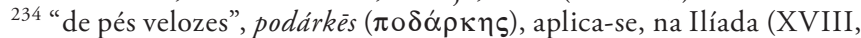
181), a Aquiles. Era também o nome de Príamo quando jovem. Há aqui um jogo gracioso entre esse epíteto e podagrós ( $\left.\pi \mathrm{o} \delta \alpha \gamma \rho \mathrm{s}_{\varsigma}\right) .$.

235 "de gota num pé", podagrós ( $\left.\pi \mathrm{o} \delta \alpha \gamma \rho \mathrm{o}_{\varsigma}\right)$, lit. "te "apanhado pelo pé"... não propriamente de gota. Alude-se à história, segundo a qual sua mãe, Tétis, o mergulhou nas águas do Estige, a fim de torná-lo imortal... mas, ao pegar-lhe pelo calcanhar (o... calcanhar de Aquiles...), impediu que a água cobrisse essa parte do corpo...

${ }^{236} \mathrm{O}$ texto diz que era podagrós ( $\left.\pi \mathrm{o} \delta \alpha \gamma \rho \gamma_{\varsigma}\right)$, "gotoso", ou, como no caso de Aquiles (e outros mais abaixo mencionados), "apanhado pelo pé”, uma história hoje não documentável, mas que estaria relacionada com o cavalo Pégaso, do qual Belerofonte foi precipitado por Zeus...

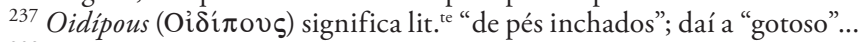

238 O "filho de Peante", Filoctetes, mordido por uma serpente, ficou coxo, mas mesmo assim foi comandante de uma parte da armada contra Tróia. 
ainda um outro, Podarces ${ }^{239}$, || que os Tessálios comandou, quando caiu em combate $\|$ seu irmão ${ }^{240}$ Protesilau, 260 mesmo gotoso e dorido, || tornou-se chefe da frota. Ulisses, de Ítaca rei $\|$ e de Laertes o filho, fui eu mesma que o matei, $\|$ não a espinha de peixe ${ }^{241} \ldots$ Ficai sabendo, ó malditos, \| que não ficareis a rir-vos, pois tereis justo castigo || pelo que andais a fazer.

\section{MÉDICO - $7 \|$ || 7 .}

265 Somos naturais da Síria, \|| de Damasco cidadãos. Vítimas de muita fome \| e de uma extrema pobreza, percorremos terra e mar, \| numa errância constante. Temos connosco um unguento, $\|$ herdado de nossos pais, com o qual aliviamos $\|$ as dores dos padecentes.

\section{GOTA $-7 \||| 7$.}

270 Diz-nos qual é esse unguento || e a sua preparaçáo.

\section{MÉDICO - 7 || 7 .}

Um juramento sagrado $\|$ manda que cale e não diga, bem como a última vontade $\|$ de meu moribundo pai, que me mandou ocultar $\|$ o grande poder da droga, com que sabia pôr fim || à tua fúria selvagem.

\section{GOTA -7|| 79$}

275 Miseráveis criaturas, || a má morte destinadas!

Haverá em todo mundo \|droga de tamanho efeito, que no corpo besuntada \|| ponha termo ao meu furor? Pois então estabeleçamos $\|$ a seguinte convençáo, a ver qual é superior $\|$ de entre as duas em presença: 280 se a força da tua droga, $\|$ ou a força dos meus ardores... Acorrei cá, ó Torturas, \|| voando de toda a parte, vós que companheiras sois \| dos meus báquicos mistérios! Chegai-vos mais para cá. || Tu o extremo dos seus pés,

${ }^{239}$ Podarces, andrónimo, significa “de pés velozes”; guerreiro em Tróia (v. Iliada, II, 704 e XIII, 693). Tal como no caso de Príamo, Luciano compraz-se em jogar (por associaçáo de opostos) com o sentido etimológico. 240 "seu irmão" não está no texto, é só para "encher" o verso...

241 Ulisses terá morrido muito velho, engasgado por uma espinha de peixe, como sugere a profecia da Odisseia, XI, 124, tema tratado por Ésquilo e Sófocles em tragédias hoje perdidas. 
no calcanhar começando, $\|$ e até à ponta dos dedos, 285 a este inflama, e tu, || entra-lhe nos tornozelos,

e das coxas aos joelhos $\|$ verte teu acre veneno, e todas vós encurvai-lhe || quantos dedos tem na mão.

DORES $-7 \| 7$.

Eis que tudo o que ordenaste $\|$ já nós o executámos. Aí jazem os infelizes, \|| altos gritos exalando, 290 co' os membros todos torcidos || por obra do nosso ataque.

GOTA $-7 \| 7$.

Vamos, pois, ó estrangeiros, || vejamos com precisão se esta droga, esta loção, \| é de alguma utilidade.

Se ela claramente for $\|$ contrária à minha acção, irei, deixando este mundo, || pràs profundezas da terra,

295 prò mais profundo do Tártaro, $\|$ despercebida e obscura... Foi aplicada a loçáo. || Vejamos se a dor acalma.

\section{MÉDICO - $7 \|$ || 7.}

Ai de mim, atormentado! Ai de mim, que estou perdido! Tenho os membros trespassados $\|$ por invisível moléstia. como seta que nem Zeus || igual lança com seu raio,

300 nem qualquer vaga do mar $\|$ ataca com tal furor, nem mesmo um grande tornado $\|$ tem uma tal violência. Será que o dente afiado $\|$ me dilacera, de Cérbero, ou o veneno de Equidna ${ }^{242} \|$ anda a devorar meu corpo, ou do Centauro a túnica \| ensopada de veneno?

305 Tem piedade, Senhora, || pois a droga não é minha, nem há nenhuma capaz $\|$ de impedir o teu caminho. Por geral consenso vences || toda a raça dos mortais.

GOTA $-7 \| 7$.

Cessai vossa acção, Torturas, $\|$ as dores aliviai dos que agora se arrependem $\|$ de me terem afrontado.

310 Que todos fiquem sabendo $\|$ que de entre todos os deuses sou a única intratável, || que não obedece a drogas,

CORO $-10 \| / 10$.

${ }^{242}$ Equidna, personagem monstruosa, metade mulher e metade serpente... donde o veneno. 
De Salmoneu ${ }^{243}$ nem mesmo a força bruta \|

com os trovốes de Zeus rivalizou,

mas pereceu co' oeito trespassado \|

do raio flamejante desse deus.

Nem Mársias ${ }^{244}$, o sátiro ficou \||

a rir-se, ao competir com Febo Apolo,

315 mas a pele suspensa de um pinheiro \|

ainda faz ouvir um som plangente.

Um luto inesquecível teve Níobe ${ }^{245} \|$

que como mãe quis competir co' a deusa,

mas agora chorosa continua $\|$

vertendo muitas lágrimas no Sípilo.

Do mesmo modo Aracne ${ }^{246}$ da Meónia \|

entrou com a Tritónide em disputa,

mas ainda hoje, após perder a forma, ॥

a tecer continua sua teia.

320 Assim a insolência dos mortais \|

náo tem comparação com o furor

dos bem-aventurados imortais: \|

de Zeus, de Leto ou Pálade, ou do Pítio.

Assim nos tragas, Gota popular, \|

um sofrimento, sim, mas bem suave,

que seja tolerável e ligeiro, \|

${ }^{243}$ Salmoneu, homem extremamente orgulhoso, decidiu imitar Zeus, construindo uma estrada de bronze, sobre a qual passava com um carro de rodas de cobre (ou de ferro), arrastando correntes, a fim de imitar o barulho do trovão; também imitou os raios, por meio de tochas que lançava à esquerda e à direita. Claro que foi fulminado por Zeus.

${ }^{244}$ Mársias, orgulhoso do seu virtuosismo como tocador de flauta, desafiou Apolo para com ele competir tocando lira. Aquele vencesse aplicaria ao outro o castigo que entendesse. Apolo, vencedor, esfolou Mársias e pendurou a pele deste num pinheiro (ou num plátano)...

${ }^{245}$ Níobe, orgulhosa dos seus sete filhos e sete filhas, dizia-se superior a Leto, que só gerara Apolo e Ártemis. Estes, para vingarem a mãe, mataram os filhos de Níobe, com excepçáo de um rapaz e uma rapariga... Níobe foi transformada numa rocha, no monte Sípilo, que continuou a verter lágrimas...

${ }^{246}$ A jovem Aracne, orgulhosa da psua perfeição como tecedeira e bordadeira, desafiou Atena (aqui designada pelo epíteto de Meónide) para uma prova de bordados. Embora ambos os trabalhos fossem perfeitos, Atena, extremamente irritada, rasgou o trabalho da sua rival e feriu-a com a naveta (ou lançadeira). Aracne, desesperada, enforcou-se, mas Atena evituo que ela morresse e transformou-a em aranha... que continuou a fiar... 
não ardente, mas breve e indolor, que se suporte bem e tenha fim, \| pouco esgotante e que nos deixe andar.

As formas da desgraça são inúmeras, A prática das dores e o costume que sirvam aos gotosos de consolo. Assim, ó companheiros de infortúnio, disfarçareis as dores...

330 Se não se cumpre aquilo que se espera, 331 um deus realizou o inesperado. Que os sofredores ${ }^{247}$ todos se conformem

333 se são de riso causa, ou de troça:

334 Tal foi por natureza a nossa sorte.

247 "sofredores", entenda-se, “... de gota”, como se depreende a seguir: são objecto de troça devido ao seu modo de andar. 
(Página deixada propositadamente em branco) 
Ocípode [O Homem dos Pés Ligeiros] 
(Página deixada propositadamente em branco) 


\section{INTRODUÇẤO}

Ocipode [O Homem dos Pés Ligeiros], funciona como sequência de $A$ Gota, mas náo é necessariamente da mesma autoria. Os críticos modernos, alguns dos quais atribuem esta última a Luciano (facto que em nada diminuiria o seu mérito literário), são praticamente unânimes em negar a mesma autoria de Ocípode. Esta apresenta-se, aqui e acolá, com pequenas lacunas, que poderiam dever-se a uma primeira versão inacabada... Por outro lado, a técnica do verso é claramente inferior à métrica de $A$ Gota, coisa que não se admitiria num escritor como Luciano. Mas a verdade é que a peça, muito mais cómica que trágica, tem a sua graça, como reconhece o autor do "Argumento" (de feitura claramente "bizantina"), cuja leitura desde já sugiro... 
(Página deixada propositadamente em branco) 


\section{Ocípode [O Homem dos Pés Ligeiros]}

\section{ARGUMENTO:}

[Ocipode era filho de Podalírio e de Astásia; distinguia-se por sua beleza e sua força, e por apreciar as actividades atléticas e cinegéticas. Muitas vezes, ao ver pessoas vitimas da impiedosa Podagra [Gota], ria-se, dizendo que essa doença não tinha absolutamente nenhuma gravidade. Então esta deusa irritou-se e atacou-lhe os pés. Como ele resistisse valentemente e se negasse a reconhecer a situação, a deusa pô-lo completamente deitado de costas.

As personagens da peça são: Podagra, Ocípode, Trofeu [Pegagogo], um Médico, a Tormento [ou Dor], um Mensageiro.

A cena da peça é suposta ser em Tebas. O coro é constituido por pacientes de gota locais, que interpelam Ocipode. A peça é extremamente engraçada.]

\section{PODAGRA [GOTA] -}

Terrível entre os mortais, || abominável de nome,

Podagra, assim sou chamada, || dos homens flagelo horrendo, cujos pés com fortes laços $\|$ mantenho bem amarrados, e nas articulações $\|$ penetro sem ser notada.

5 Rio-me dos atacados \| pela minha violência, e que a verdadeira causa $\|$ não confessam de seu mal. mas que ao invés lhe atribuem \| algum frívolo motivo. Todos tentam iludir-se, || alegando mil desculpas; aos seus amigos um diz \| que foi por torcer um pé

10 ou por ter batido em algo, || sem confessar a verdade, mas aquilo que não diz, || cuidando que engana os outros, o próprio tempo, correndo, || revela-o queira ou não queira. Então, uma vez vencido, || e meu nome declarando, é em "triunfo" levado \| nos braços dos seus amigos.

15 O Tormento ${ }^{248}$ é, nestes males, \| o meu colaborador, que eu sozinha nada sou $\|$ sem a sua companhia.

Mas o que mais me atormenta $\|$ e me deixa furibunda é que ninguém considera || causa de todos os males o Tormento, nem o insulta || com palavras ofensivas,

20 mas é contra mim que lançam \| horríveis imprecações, na esperança de escapar $\|$ aos meus apertados laços...

248 “Tormento", ou Dor, gr. Pónos (Пóvo૬). Entendi traduzir, ainda que com menor precisão, por um termo que fosse também, em port., do género masculino. 
Mas porque digo estas coisas, || e não declaro o motivo por que aqui estou, sem poder $\|$ minha raiva suportar? O nobre mestre de embustes ${ }^{249}$, || Ocípode, esse insolente,

25 despreza a minha pessoa, || dizendo que eu nada valho. Então eu, como mulher, $\|$ de grande furor mordida, por minha vez o mordi ${ }^{250} \|$ com justo golpe incurável, como tenho por costume, $\|$ no artelho o atingindo. Já o terrível Tormento || um pequeno espaço ocupa,

30 mas já vai co’ umas picadas || minando a sola do pé. Mas ele tenta enganar || o seu velho e pobre mestre, como se ferisse o pé || ou na corrida ou na luta; e ao sair de sua casa, || ei-lo que vai avançando, pondo o pé suavemente, $\|$ tentando esconder que manca.

\section{OCÍPODE ${ }^{25}$}

35 Donde é que esta dor terrível || sobre os meus pés terá vindo,

não causada por pancada, || nem por mau passo ou por queda?

Tenho o tendão muito tenso, || tal e qual como o frecheiro ao disparar sua flecha, $\|$ o que me obriga a dizer:

"O fim destas minhas dores || ainda vai levar seu tempo."

\section{PEDAGOGO -}

40 Vamos, ergue-te, meu filho, \| e mexe bem esses pés, e que ao coxear náo caias $\|$ e não me arrastes contigo.

\section{OCÍPODE}

Já te estou obedecendo, || em ti me apoio sem peso; no chão o pé dolorido \|| já estou pondo e aguento. Sim, é vergonha pra um jovem \|| ter por ajuda nas quedas

249 "de embustes", genit. pl. dólōn ( $\delta$ ó $\lambda \omega v)$ também tem sido interpretado como o andrónimo (nominat.) Dólōn $(\Delta o ́ \lambda \omega v)$, que sugere fortemente o herói troiano Dólon, "de pés ligeiros” (Il., X, 316). Todavia, a interpretação desta palavra como andrónimo está prejudicada pelo facto de o nome da personagem, Ocípode, vir logo a seguir.

${ }^{250} \mathrm{O}$ aor. $1^{\circ}$ antédaka ( $\left.\alpha \nu \tau \varepsilon \dot{\varepsilon} \delta \kappa \kappa\right)$, em vez do aor. $2^{\circ}$ em -on (-ov) denota uma época tardia, nitidamente pós-clássica, onde, no entanto, temos exemplos de convivência dos dois aoristos. A substituição do aor. $2^{\circ}$ pelo aor. $1^{\circ}$ acabou por se generalizar, até ao gr. mod.

${ }^{251}$ Sigo Guyet (apud "Loeb", VIII, p. 361), que atribui os cinco versos seguintes a Ocípode. 
45 um velho que além de fraco || não faz senão murmurar.

\section{PEDAGOGO -}

Isso não, meu insensato, || não ralhes assim comigo, com essa altivez de jovem, \|| porque bem deves saber que nas horas de aflição \|| todo o velho se faz jovem ${ }^{252}$. Obedece ao que te digo. || Se eu retirar meu apoio, $50 \mathrm{eu}$, velho, fico de pé, || e tu, jovem, vais ao chão.

\section{OCÍPODE -}

Se tu caíres, caíste \|| não do mal, mas da velhice; nos velhos persiste ainda || notável força mental, mas falta-lhes energia, || quando se trata de agir.

\section{PEDAGOGO -}

Que sofista me saíste! || Não me dizes de que modo 55 essa tal dor penetrou || na planta do teu pé?

\section{OCÍPODE}

Estava a praticar corrida, || e pra pôr suave o pé, corria com passo largo, || quando sobreveio a dor ${ }^{253}$.

\section{PEDAGOGO -}

Vai correndo, como disse || um que estava depilando a barba, mas precisando $\|$ de rapar a farta axila ${ }^{254}$.

\section{OCÍPODE -}

60 De facto, estava lutando... || Ao pretender aplicar uma rasteira, feri-me. || Podes crer que é a verdade.

\section{PEDAGOGO}

Que soldado me saíste! || Ao quereres aplicar uma rasteira, feriste-te! || Que falsa história me impinges! Também eu contei outrora || uma história semelhante,

252 "todo o velho se faz jovem", sentido confirmado pelos vv. 49-50, e não (invertendo o sujeito e o nome predicativo do sujeito) "todo o jovem se faz (i, é, "chegará a”) velho".

${ }^{253}$ Devo dizer que a tradução dos vv. 56 (20 hemistíquio) e 57 é algo problemática...

${ }^{254}$ Trata-se de um dito proverbial, cujo sentido exacto me escapa, mas que significa que o outro náo era convincente... E de facto, logo a seguir, Ocípode dá outra desculpa... 
65 a verdade não contando $\|$ a nenhum dos meus amigos. Mas agora, como vês, \| toda a gente descobriu... A grande dor que o sacode || fá-lo contorcer-se todo ${ }^{255}$.

\section{MÉDICO -}

Onde é que o ilustre Ocípode \|| posso, amigos, encontrar, que tem doença de pés, || que não lhe permite andar?

70 Sou médico e ouvi dizer \| da boca de um seu ${ }^{256}$ amigo que sofre muito do mal || que o não deixa ter-se em pé $^{257}$... Mas ei-lo aqui em pessoa, || mesmo em frente dos meus olhos, ei-lo jazente no leito, || para ali deitado de costas... Eu te saúdo, plos deuses! || Mas essa tua doença,

75 que raio de coisa é? || Diz-me, Ocípode, e depressa. Se eu conseguir saber, || talvez possa dar remédio a essa terrível dor, || à desgraça do teu mal.

\section{OCÍPODE -}

Tu mesmo me vês, ó sóter ${ }^{258}$, || melhor dizendo, Sotérico, que tens da deusa "Trombeta" || o mesmo nome, Sotérico: 80 uma horrível dor no pé || bem cruelmente me morde, ao poisar os pés no chão, $\|$ e andar timidamente.

\section{MÉDICO -}

Diz-me donde veio o mal || e de que modo surgiu, pois ao saber a verdade, \| o médico intervirá com segurança maior, || mas erra, se náo souber.

\section{OCÍPODE -}

85 Ao praticar a corrida || e as artes do ginásio, fui gravemente ferido \| por meus caros companheiros.

\section{MÉDICO -}

Porque não tens um inchaço || bastante desagradável

255 Esta frase é um aparte.

256 “seu”... ou "meu": o texto não especifica.

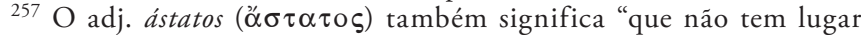
certo"... "difuso", pois a gota "desloca-se por diversas partes do corpo.

258 sóter, gr. sōtêr ( $\sigma \omega \tau \eta \dot{\rho} \rho)$ "salvador”, termo comum que Ocípode associa ao nome do médico, Sōtérikhos ( $\Sigma \omega \tau \eta \dot{p} \rho \imath \chi 0 \varsigma)$. Para manter a associação, com o andrónimo, houve que manter a forma grega do nome-adj.; "Trombeta" era um raro epíteto de Atena, mais conhecida pelo epíteto de Sóteira ( $\Sigma \omega \dot{\tau} \tau \imath \iota \alpha)$ "Salvadora". Tanta subtileza... não sei se os próprios gregos a entenderiam bem... 
no próprio local do golpe, || e não tens uma compressa?

\section{OCÍPODE -}

Não suporto sobre a pele || as ligaduras de lá, 90 uma beleza pra muitos, || mas inúteis, afinal.

\section{MÉDICO -}

Então que é que te parece? || Vou lancetar o teu pé?

Se permitires que o faça, || fica desde já sabendo que com essa incisão \| retiro-te muito sangue.

\section{OCÍPODE}

Procede assim, se de facto || nova forma descobriste 95 de logo pôr termo à dor, || horrenda dor dos meus pés.

\section{MÉDICO -}

Eis que o escalpelo te aplico, || de liga de cobre e ferro, bem afiado e de sangue $\|$ sequioso e encurvado.

\section{PEDAGOGO -}

98 Pára! Pára! 259

Que estás, "Salvador”, fazendo? || Assim não podes salvá-lo. 100 Ousas juntar-lhe uma dor || provocada pelo ferro?

Sem a verdade saberes, || mais um mal aos seus pés causas, pois não passam de mentiras $\|$ as palavras que lhe ouviste. Não foi, não, como ele afirma, || nas lutas nem nas corridas, que ao praticar se feriu. I| Ouve antes o que te digo:

105 Para já, chegou a casa || com boa disposição.

Depois comeu e bebeu \| mais que a conta, o desgraçado, após o que foi deitar-se $\|$ e adormeceu sozinho ${ }^{260}$. Tendo acordado de noite, || enormes gritos soltava, como de um deus possuído \| e todo ele em grande pânico. 110 E disse então: "Ai de mim, || donde veio esta desgraça? Algum deus me está prendendo || e quer arrancar-me o pé." Depois passou toda a noite || só e sentado na cama,

${ }^{259}$ Há quem atribua estas duas palavras ao paciente. Sigo a interpretação da ed. "Loeb".

260 "sozinho"... é o que diz o texto: mónos ( $\mu$ óvos). De facto, como se vê a seguir, o homem pssou toda a noite sem ajuda (v. 112). 
qual andorinha-do-mar ${ }^{261}$, || gemendo pelo seu pé. Todavia, assim que o galo \| trombeteou a alvorada,

115 avançou e, sobre mim \| pondo a máo amargurada ${ }^{262}$, gemendo e ardendo em febre, $\|<$ queixou-se de dor nos pés $^{263}$. >

O que ele antes te contou || não passa de uma mentira, com que tentava esconder $\|$ o segredo da doença.

\section{OCÍPODE -}

Um homem velho está sempre || bem armado de palavras, 120 de tudo se vangloria, || mas incapaz de fazer ${ }^{264}$.

Aquele que sente dores, || mas aos seus amigos mente, ao faminto se assemelha, $\|$ mas que mastiga lentisco ${ }^{265}$.

\section{MÉDICO -}

Induzes todos em erro, || não dizes coisa com coisa: dizes que estás dolorido, $\|$ mas não a causa da dor.

\section{OCÍPODE}

125 Como poderei dizer-te || o que causa o sofrimento? Sofro, mas mais nada sei, $\|$ só sei que sofro, e mais nada.

\section{MÉDICO -} num pé,

Quando, sem causa aparente, \| um homem tem dor

falsos motivos inventa, $\|$ aqueles que bem entende, mesmo sabendo a que causa $\|$ se deve sua moléstia. 130 Neste preciso momento, $\|<$ um único pé te dói. $>^{266}$

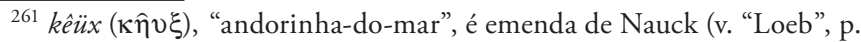

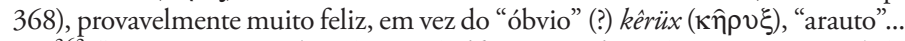

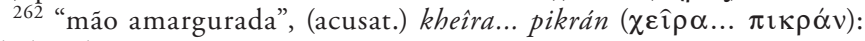
bela hipálage...

263 Os mss. têm neste passo uma lacuna, que tem sido diversamente preenchida. Sigo a proposta de Radermacher (apud "Loeb", VIII, pp. 368-369), por muito insegura que seja...

${ }^{264} \mathrm{O} 2^{\circ}$ hemistíquio contém um hiato nada canónico: em vez de $\mu \eta \delta \dot{\varepsilon}$ $\tilde{\varepsilon} \nu \sigma \theta \dot{\varepsilon} v \omega \nu$, daria "jeito" ler $\mu \eta \delta \dot{\varepsilon} \nu ~ \alpha ُ \sigma \theta \varepsilon \nu \hat{\omega} \nu$, o que significaria "sem estar nada doente", mas teríamos de explicar este sentido...

${ }^{265}$ Nestes quatro versos, há uma comparação, algo desajeitada, entre a aparência e a realidade: assim como o palavreado esconde a capacidade de acção, também o hálito do lentisco disfarça a fome...

${ }^{266}$ Os mss. têm aqui uma lacuna. Sigo a sugestão de Zimmermenn (apud “Loeb”, VIII, p. 370). 
Quando, porém, te doer || igualmente o outro pé, com gemidos virão lágrimas. || Mas isto te vou dizer: trata-se da tal doença...., $\|$ quer tu queiras, quer não queiras.

\section{OCÍPODE}

Mas qual é essa doença? || Diz-me lá como se chama.

\section{MÉDICO -}

135 Seu nome é constituído \| por dupla reunião...

\section{OCÍPODE -}

Ai de mim! Que nome é esse? || Responde-me ao que te peço.

\section{MÉDICO -}

A palavra tem começo $\|$ no local onde te dói.

\section{OCÍPODE -}

Tem então o seu começo, \| como dizes, no meu... $\operatorname{pod} \ldots{ }^{267}[" p e ́$ "]

\section{MÉDICO -}

Agora acrescenta a este || no fim a terrível... ágra.["caça"]

\section{OCÍPODE -}

140 Mas $<$ sendo eu ainda jovem ${ }^{268}>$, \| como é que ela me agarrou?

\section{PEDAGOGO ${ }^{269}$}

Terrível como ela é, || não poupa mesmo ninguém.

\section{OCÍPODE -}

Que dizes a isto, Sóter? \| Que coisa... [< devo fazer $\left.{ }^{270}>\right]$

${ }^{267}$ Tratando-se de explicar o sentido e a formação da palavra gr. podágra $(\pi \circ \delta \alpha ́ \gamma \rho \alpha)$, port. podagra (= vulgar gota), há que manter os elementos gregos: pod-ágra, doença "que caça (o homem) pelo pé".

${ }^{268}$ Lacuna nos mss., preenchida por Radermacher (apud “Loeb”).

${ }^{269}$ Há quem atribua este comentário ao Médico, Sóter, mas a nomeação deste no v. seguinte parece indicar que náo foi ele, mas o Pedagogo, quem fez o comentário...

${ }^{270}$ Ou lacuna... ou o Médico interrompe mesmo a fala do paciente. 


\section{MÉDICO -}

Deixa-me só por momentos... $\|$ Enganei-me a teu respeito ${ }^{271}$.

\section{OCÍPODE}

Que coisa ruim é essa? || Que é que se passa comigo?

\section{MÉDICO -}

145 Terrível mal contraíste, || que não largará teu pé.

\section{OCÍPODE -}

Terei então de passar || o resto da vida coxo?

\section{MÉDICO -}

O ficar coxo somente, || não é nada... não receies.

\section{OCÍPODE}

Que coisa pior........? ${ }^{272}$

\section{MÉDICO -}

O teu destino é ficar $\|$ de ambos os pés emperrado.

\section{OCÍPODE}

150 Ai de mim! Donde me veio || agora esta nova dor, que ao longo do outro pé, || me faz sofrer cruelmente?273 Porque estou inteiriçado, || ao pretender deslocar-me? Tenho um medo pavoroso \| de o meu pé movimentar, medo infantil, de bebé $\|$ de repente apavorado.

155 Ó Sotérico, meu caro ${ }^{274}$, || imploro-te, pelos deuses: se porventura tiver $\|$ tua arte algum poder, não me desprezes, mas cura-me, $\|$ ou então estarei perdido. Padeço de um mal oculto, \| que meus pés criva de setas.

\section{MÉDICO -}

As palavras rejeitando, || próprias de charlatães,

${ }^{271}$ cf. vv. 91, ss., em que o médico pretende lancetar o doente...

${ }^{272}$ Mais uma lacuna. Tal como as lacunas precedentes - fique agora dito - pode mesmo tratar-se de verso(s) inacabado(s)... (?). Herwerden (apud "Loeb", VIII, p. 375) preenche de maneira plausível, mas, naturalmente, incerta: “... do que este mal que dizes. Explica-te”.

${ }^{273}$ Entre diversas "emendas"... sigo os manuscritos...

274 "meu caro"... é só para encher o verso... 
160 de médicos que só sabem || belos discursos fazer, que não conhecem, na prática, || qualquer droga salvadora, tudo te irei explicar, \| brevemente, a ti, que sofres. Para já, chegaste ao fundo \| incurável de teus males. De facto, grilhôes de ferro || não tens "calçados" nos pés,

165 como marca bem visível, \| aos criminosos imposta, mas sim um terrível cepo ${ }^{275}$, $\|$ oculto a todos os olhos, cujo peso nenhum homem $\|$ é capaz de levantar.

\section{OCÍPODE}

168 Aiai! Aiai! Ai de mim!

Mas que dor secreta é esta, \|| que está furando o meu pé?

170 Segurai-me ${ }^{276}$ pelos braços ${ }^{277}$, || antes que venha a cair, como os Sátiros transportam || pelo sovaco os Bacantes.

\section{PEDAGOGO -}

Sou velho, mas mesmo assim, \| obedeço ao que me pedes, e conduzo pela mão $\|$ eu, velho, a ti que és um jovem.

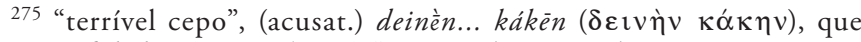

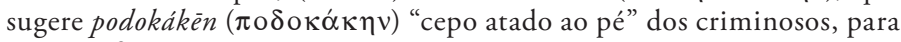
que náo fugissem.

276 "Segurai-me": o plural sugere que se dirige a mais que uma pessoa...

277 "braços": é este, aqui, o sentido de (acusat.) kheîras ( $\chi \varepsilon \hat{\imath} \rho \alpha \varsigma)$ ), como se vê pela comparação do v. seguinte; cf. poús ( $\pi$ oús) no sentido de "perna". 
(Página deixada propositadamente em branco) 
O Patriota ou O Discípulo 
(Página deixada propositadamente em branco) 


\section{INTRODUÇẤO}

Eis uma obra que, garantidamente, não é da autoria de Luciano, mas de algum escritor bizantino (séc. X), eventualmente do mesmo nome... o que induziria à confusão. Este diálogo foi escrito no tempo do imperador bizantino Nicéforo II Focas (n. 912, imperador entre 963 e 969), numa época de expansionismo do Império e de confronto com os Sarracenos, aos quais Focas reconquistou Creta e derrotou em diversas batalhas travadas na Cilícia, na Mesopotâmia e na Síria, factos de que temos algum eco nesta mesma obra.

O subtítulo, Didaskómenos ( $\Delta \mathrm{t} \delta \alpha \sigma \kappa o ́ \mu \varepsilon v o \varsigma)$ pode ser vertido de diversas maneiras: "O Instruendo", "O Discipulo", "O Iniciando", ou mesmo "O Catecúmeno", aproveitando a

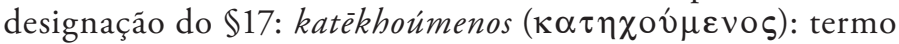
de sentido tipicamente cristáo.

O Patriota está escrito num grego que pretende ser clássico, mas que mistura os mais diversos tipos de linguagem, incluindo elementos contemporâneos, num conjunto linguístico muito incoerente e muito pobre.

Além do mais, está imbuído de um espírito ao mesmo tempo imperial, patriótico e cristáo, que, só por si, excluiria Luciano da sua autoria. Uma das suas personagens, Crícias, está imbuído de uma forte cultura clássica e da sua mitologia, contrariada pela outra personagem, Triefonte, que funciona como mestre de Crícias em matéria de Cristianismo e em fervor patriótico, onde é clara a devoção, simultaneamente, à Ortodoxia e ao Imperador, o que leva a supor que se trata de uma obra especialmente destinada a louvar o Imperador, com os benefícios daí resultantes.

A propósito do juramento tradicional por esta ou aquela das divindades "clássicas", Triefonte aproveita para criticar a baixa moralidade dos deuses antigos, tudo no sentido de introduzir no espírito do seu interlocutor e instruendo a crença nos pilares do Cristianismo, nomeadamente a Santíssima Trindade, como se lê no $\$ 12$ :

Por esse deus altíssimo e grande, || deus imortal e celeste, pelo Filho e pelo Espírito \| ambos do Pai procedentes, um em três e três em um.

Tem esse pelo teu Zeus, || e crê que só esse é Deus ${ }^{(278)}$.

${ }^{278}$ Aqui o autor transcreve um verso de Eurípides, de uma tragédia perdida. 
(Página deixada propositadamente em branco) 


\section{O Patriota ou O Discípulo}

1. TRIEFONTE - Que é isso, ó Crícias?279 Estás completamente alterado, com as sobrancelhas franzidas, profundamente ensimesmado, andando de um lado para o outro, mais parecido, como diz o poeta, com "raposáo astucioso" 280 , e com "a palidez no rosto estampada". Não terás tu visto o Tricéfalo ${ }^{281}$, ou Hécate saída do reino de Hades, ou não terás, sem que o esperasses, encontrado algum dos deuses? Realmente, não é natural que tu te encontres nesse estado, mesmo que ouvisses dizer que o próprio mundo tinha sido inundado, como no tempo de Deucaliāo... Estou a falar contigo, meu caro Crícias! Não me ouves a gritar-te com toda a força e muito chegado a ti? Estarás zangado comigo? Ou estarás surdo? Ou estarás à espera de que eu te dê uma sacudidela?

CRÍCIAS - Ó Triefonte, acabo de ouvir um discurso muito longo, intrincado e serpenteante por diversos caminhos, e então rememoro aquelas inépcias e tapo os ouvidos, não se dê o caso de ainda escutar tais coisas e vir a morrer petrificado ${ }^{282}$ de loucura, tornando-me assim um mito para os poetas, como anteriormente Níobe. Mas eu, devido a uma vertigem, ter-me-ia lançado de cabeça por um precipício, se tu, meu caro, não me tivesses gritado, e então o salto de Cleómbroto de Ambrácia ${ }^{283}$ passaria também à lenda, mas a meu respeito.

2. TRIEFONTE - Por Héracles!, que espantosas visões e histórias terão assombrado Crícias?! Quantos poetas assombrosos e quantas monstruosa invenções dos filósofos não conseguiram assombrar o teu espírito, mas foram tidas por ti como conversa vazia?

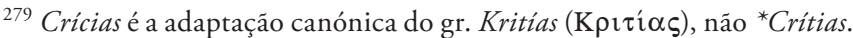

280 "raposão astucioso", ou seja, Ulisses (Il., IV, 339); para a citação seguinte, v. Il., III, 35, referência a Páris, que ficou pálido ao ver aproximar-se Agamémnon. Qualquer das alusóes não é muito feliz.

${ }^{281} \mathrm{O}$ "Tricéfalo" é o cão de guarda do Hades, Cérbero. Hécate, deusa infernal, é aqui citada no seu aspecto malfazejo...

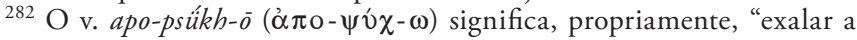
alma", "morrer", mas também pode ter, como aqui, a conotação de "frio",

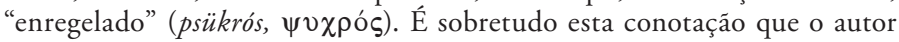
aproveita, ao evocar o caso de Níobe, que foi, por puniçáo divina, petrificada...

${ }^{283}$ Discípulo de Sócrates, que se lançou de uma muralha, depois de ler o Fédon de Platáo, que versava a imortalidade da alma. 
CRÍCIAS - Detém-te um pouco e deixa de me incomodar, ó Triefonte, pois, pela minha parte, nunca serás ignorado ou desprezado ${ }^{284}$.

TRIEFONTE - Estou vendo que revolves no teu espírito um assunto nada mesquinho nem despiciendo, mas algo extremamente misterioso. Sim, a cor do teu rosto, esse teu olhar de touro, essa passada incerta e esse andar para cima e para baixo indicam claramente isso mesmo... Ora sopra cá para fora essas coisas terríveis, vomita-me essas inépcias, "não te aconteça algum mal" ${ }^{285}$.

CRÍCIAS - Tu, ó Triefonte, afasta-te de mim para aí um pletro $^{286}$, ainda assim o meu sopro ${ }^{287}$ náo te eleve nos ares e te mantenha suspenso à vista de toda a gente, de modo que tu, ao despenhares-te, dês o nome ao mar...Triefonteu, tal como Ícaro antes de $\mathrm{ti}^{288}$. Na verdade, aquilo que hoje ouvi da boca desses três vezes malditos sofistas até me fez inchar a barriga.

TRIEFONTE - Sim, sim, eu vou afastar-me quanto quiseres, e tu sopra cá para fora as coisas terríveis.

CRÍCIAS — Uh! Uh! Uh! Uh!... Que inépcias! Iú! Iú! Iú! Iú!... Que ideias tão terríveis! Ah! Ah! Ah! Ah!... Que esperanças tão vãs!

3. TRIEFONTE - Oh! Que grande ventania, que até dispersou as nuvens! Na verdade, quando já soprava o Zéfiro ${ }^{289}$, impetuoso e agitando as ondas, tu acabas de desencadear o Bóreas ao longo da Propôntida ${ }^{290}$, de modo que, devido às ondas revoltas pelo vento, só a poder de cabos é que os navios mercantes passam para o Ponto Euxino... Mas que grande

${ }^{284}$ A ideia (algo difícil de meter no contexto) parece ser: "não me aborreças, que eu também não te aborreço”.

${ }^{285}$ Embora o autor tenha dado à frase a forma métrica (10 hemistíquio), Homero diz (p.ex. Od., XVII, 596), mais sucintamente, "não sofras algo":

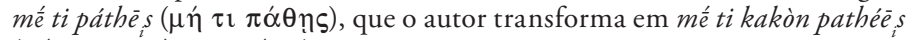

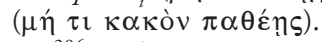

${ }^{286} 1$ pletro = 100 pés, ou seja, c. 29,6m.: "para aí uns bons trinta metros" (se me é permitida a quase equivalência...

287 "sopro", pegando na frase acima "sopra cá para fora".

288 Referência ao mar Icário, assim denominado por nele se ter despenhado o imprudente Ícaro.

289 Zéfiro é um vento de Noroeste; Bóreas é um vento também do quadrante Norte.

${ }^{290}$ Propôntida (actualmente mar de Mármara), entre o Helesponto e o Bósforo. 
tumor estava dentro das tuas entranhas! Que grande burburinho e que tumulto agitava o teu estômago! Ao escutares tais e tantos disparates, tu ficaste... "todo-orelhas", a ponto de até pelas unhas ouvires esses discursos prodigiosos.

CRÍCIAS — Não é de estranhar, Triefonte, que uma pessoa oiça pelas orelhas, pois já se viu uma perna tornar-se ventre ${ }^{291}$, uma cabeça dar à luz, um homem passar misteriosamente a ser mulher, e mulheres metamorfoseadas em aves. Em suma, a vida é um prodígio... a acreditar nos poetas... Ora,

\section{"já que tu és o primeiro \| que encontro neste lugar"292,}

vamos para um local onde os plátanos nos defendem do sol e os rouxinóis e as andorinhas cantam harmoniosamente, para que a melodia dos passarinhos, que encanta os nossos ouvidos, e a água sussurrando docemente, cativem as nossas almas.

4. TRIEFONTE - Vamos, pois, ó Crícias. Mas receio que aquilo que tu escutaste seja um encantamento e que esse teu maravilhoso assombro me transforme em piláo de almofariz, ou numa porta, ou em qualquer outro objecto inanimado.

CRÍCIAS - Não, por Zeus Celeste! Não te acontecerá tal coisa.

TRIEFONTE - Ao jurares por Zeus, ainda mais de amedrontaste. Sim, como é que ele poderá punir-te, se tu violares o teu juramento? Realmente, eu sei que tu não és ignorante a respeito de Zeus.

CRÍCIAS - Que queres dizer com isso? Não será Zeus capaz de me enviar para o Tártaro? Ou será que desconheces que ele despenhou todos os deuses lá da morada celeste, e que ainda recentemente fulminou Salmoneu, que trovejava contra ele, bem como, ainda actualmente, os mais insolentes, ele que

291 Referência a Dioniso, filho de Zeus e da mortal Sémele. Após a morte desta, já grávida, fulminada pelo simples facto de fixar Zeus em todo o seu esplendor, o pai, Zeus, fez uma incisão na própria perna, que serviu de "ventre", donde nasceu a criança em seu devido tempo. Seguem-se outros casos: de Atena, nascida já armada da cabeça de Zeus; do adivinho Tirésias, que já fora mulher; Alcíone, Filomela e Procne foram transformadas, respectivamente, em alcíone (alcião ou andorinha-do-msr), andorinha e rouxinol.

${ }^{292}$ Homero, Od., XIII, 228 e XV, 260, com citação adaptada. 
é celebrado pelos poetas, nomeadamente por Homero, como "Vencedor-dos-Titäs" e "Matador dos Gigantes"?293.

TRIEFONTE - Realmente, tu, ó Crícias, pintaste a traços largos os atributos de Zeus... mas, por favor, escuta-me. Não se transfigurou ele, por devassidão, em cisne, em sátiro, mas também em touro? ${ }^{294} \mathrm{E}$ se ele não tivesse levado sobre o lombo a jovem prostituta ${ }^{295}$ e não fugisse com ela através do mar, talvez acabasse a lavrar [a terra] para um lavrador, esse teu Zeus trovejante e relampejante, e, em vez de relampejar, talvez fosse ele o espicaçado pelo aguilhão do boieiro ${ }^{296}$. E não devia ele, com aquela sua farta barba, ter vergonha de se banquetear na companhia dos Etíopes, homens muito escuros, de rosto negro, e de não sair dali durante doze sóis, sentado com eles a embebedar-se? Quanto aos episódios da águia, do monte Ida e dos seus partos por todas as partes do corpo ${ }^{297}$, até me envergonho de falar.

5. CRÍCIAS - Deverei entấo, meu caro, jurar por Apolo, que é um excelente profeta e médico?

TRIEFONTE - Referes-te a esse falso adivinho, que ainda recentemente aniquilou Creso e, depois deste, Salamínios e milhares de outros, ao emitir oráculos com dois sentidos, [que davam] para todos?

6. CRÍCIAS - Então que é que dizes de Posídon, que empunha nas suas máos o tridente, que na guerra clama com voz tão penetrante e aterradora como nove ou dez mil homens, mas também, ó Triefonte, é apelidado de "Sacudidor da Terra"298?

293 Estes dois epítetos não ocorrem em Homero...

${ }^{294}$ Referência aos amores de Zeus com, respectivamente, Leda, Antíope e Europa.

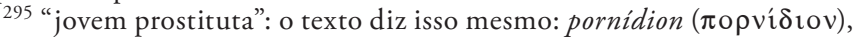
que certamente náo se aplica no contexto do mito. Só este facto bastaria para não atribuirmos a Luciano a autoria desta obra.

${ }^{296}$ Recorde-se que Zeus se transformara em touro...

297 Referência a Atena e a Dioniso, nascidos respectivamente, da cabeça e da barriga da perna de Zeus.

298 "Sacudidor da Terra", gr. seisikhthōn ( $\sigma \varepsilon \imath \sigma i \chi \theta \omega v)$, epíteto que ocorre em Píndaro; em Homero e em Hesíodo, o epíteto, com o mesmo

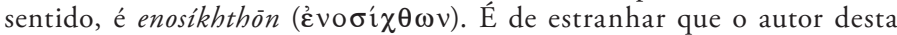
obra não tivesse usado o epíteto habitual, menos explícito para um grego tardio (bizantino), mas não para Luciano... se este fosse o autor da obra. 
TRIEFONTE - Referes-te a esse adúltero ${ }^{299}$, que ainda recentemente violou a filha de Salmoneu, Tiro ${ }^{300}$, e que ainda hoje continua a dar-se à libertinagem e é protector e patrono de personagens da sua laia? Sim, quando Ares estava preso na rede [mágica] e apertado, juntamente com Afrodite, nas suas malhas impossíveis de desfazer, e enquanto todos os deuses, por vergonha, guardavam silêncio acerca do adultério, Posídon, o deus cavaleiro, pôs-se a chorar, desfeito em lágrimas, como as criancinhas com medo dos seus professores ou como as velhas que tentam enganar as jovens. Então instou com Hefesto para que libertasse Ares, e então esta divindade coxa, apiedando-se do velho deus, libertou Ares. Portanto, Posídon é adúltero, pelo facto de proteger um adúltero.

\section{CRÍCIAS - E que dizer de Hermes?}

TRIEFONTE - Não me fales desse vil escravo do desavergonhadíssimo Zeus, desse tipo furiosamente louco por actividades adúlteras.

8. CRÍCIAS - Quanto a Ares e a Afrodite, já sei que não os aceitas, a julgar pelo facto de ainda agora terem sido por ti atacados. Portanto, deixemos estes [dois]. Mas vou ainda mencionar Atena, a virgem, a deusa armada e aterradora, aquela que tem estampada no peito a cabeça da Górgona ${ }^{301}$, [Atena] "matadora de Gigantes"302. De facto, não tens nada que apontar a seu respeito.

TRIEFONTE - Faço-te, porém, uma observação também a respeito desta... se quiseres responder-me...

CRÍCIAS - Diz lá o que entenderes.

TRIEFONTE - Diz-me cá, ó Crícias, qual é a utilidade da Górgone e por que razáo a deusa a traz ao peito.

${ }^{299}$ Como se vê a seguir, o caso passado com a jovem Tiro é uma autêntica violaçáo, náo propriamente um adultério... mas veja-se o final do parágrafo.

${ }^{300}$ Tiro (não confundir com outra, que era uma ninfa) enamorou-se do deus-rio Enipeu, e foi nas margens deste rio que Posídon, disfarçado de Enipeu, violou a jovem.

301 Górgona, ou (forma mais erudita) Górgone.

302 "matadora de Gigantes": Como diz M. D. Macleod, tradutor da obra ("Loeb", VIII, p. 429), o epíteto devia estar em genitivo, a concordar com tês Athēnâs ( $\tau \hat{\eta} \varsigma$ 'A $\theta \eta \nu \hat{\alpha} \varsigma$ ). O erro gramatical sugere fortemente um autor (bizantino) tardio... náo Luciano. 
CRÍCIAS - Como essa visão é aterradora e preservadora de males! Além disso, aterroriza os inimigos e dá a vitória a qualquer das duas partes, a seu bel-prazer.

TRIEFONTE — Será então por esse facto que a deusa “de olhos garços" é invencível?

CRÍCIAS - Certamente que sim.

TRIEFONTE - Então porque é que não sacrificamos coxas de touros ou de cabras em honra não dos que têm a capacidade de salvar ${ }^{303}$, mas dos que são salvos, para que aqueles nos tornem igualmente invencíveis, como fazem a Atena?

CRÍCIAS - É que ela [a Górgone] não tem o poder de socorrer à distância, como [acontece] com os deuses, mas somente se alguém a usa sobre si.

9. TRIEFONTE - Mas que ser vem a ser esse? Sim, quero sabê-lo da tua boca, como pessoa que tem investigado essa matéria e que tem tido nisso grande êxito. Realmente, ignoro tudo sobre essa entidade, a não ser o nome.

CRÍCIAS - Ela era uma jovem bem-parecida e amorosa. Por outro lado, Perseu cortou-lhe a cabeça por meio de uma manha, ele que era um homem corajoso e famoso nas artes mágicas, depois de a ter enfeitiçado com fórmulas mágicas. Depois os deuses fizeram dela um amuleto ${ }^{304}$.

TRIEFONTE — Eu ignorava essa ela particularidade, ou seja, que os deuses necessitavam dos humanos... Mas, quando ela era viva, qual era a sua função? Será que exercia a prostituição nalgum albergue, ou sujeitava-se secretamente a relaçóes sexuais e, desse modo, chamava-se "menina"?

CRÍCIAS — Pelo Deus Desconhecido! ${ }^{305}$, lá em Atenas, continuou virgem até lhe cortarem a cabeça.

TRIEFONTE - Então, se alguém cortar a cabeça a uma virgem, será que a cabeça se tornaria num espantalho aterra-

303 "os que têm a capacidade de salvar", aqui, especificamente, a Górgone; logo a seguir, "os que são salvos” refere-se a Atena, pois é a ela que a Górgona defende. Com uma certa ironia, o autor acha que é a Górgone, e não Atena, quem merece todas as honras.

${ }^{304}$ A história está excessivamente resumida...

305 Alusão ao episódio de Paulo em Atenas perante o Areópago (Actos dos Apóst., XVII. 23). Conta ele que viu uma inscrição que dizia $\mathrm{A} \Gamma \mathrm{N} \Omega \Sigma$ -

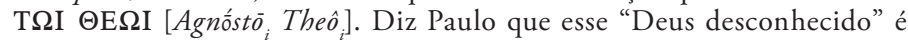
precisamente Jesus Cristo". 
dor para muitas pessoas? Na verdade, sei de inúmeras jovens esquartejadas membro por membro,

"em ilha de mar cercada," |. ... "a que os homens chamam..."306

Creta. Se eu soubesse de tal coisa, meu bom Crícias, quantas Górgones te traria de Creta?! Então faria de ti um general ${ }^{307}$ invencível, e os poetas e os oradores colocar-me-iam muito acima de Perseu, por ter 'descoberto' muitas mais... Górgones...

10. ... E já que recordei os factos de Creta, eles [os locais] mostraram-me o túmulo do $t e u^{308}$ Zeus, bem como o bosque onde foi criada a sua mãe $e^{309}$, pelo que esses bosques continuam sempre verdejantes.

CRÍCIAS - Mas tu não conhecias o canto mágico nem os rituais orgiásticos ${ }^{310} \ldots$

TRIEFONTE - Ó Crícias! Se isso dependesse de um canto mágico, talvez este pudesse trazer pessoas de entre o monte de mortos e conduzi-las à dulcíssima luz... Mas isso são divagaçôes, contos de crianças, fábulas e monstruosidades contadas pelos poetas... Mas deixa lá essa ${ }^{311}$.

11. CRÍCIAS — Mas então também não aceitas Hera, a esposa e irmã de Zeus?

TRIEFONTE - Não me fales dessa união tão vergonhosa, póe de lado essa deitada no cháo de máos e pernas abertas ${ }^{312}$.

12. CRÍCIAS - Então por quem é que devo jurar?

TRIEFONTE -

306 Verso tirado de dois hemistíquios homéricos $(O d$., I, 50 e $I l$., V,

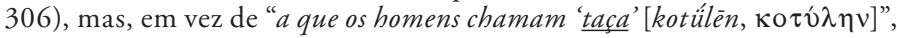
ou seja, fig. ${ }^{\text {te }}$ e em situação completamente diferente, "articulação entre a anca e a coxa". O autor substituiu "coxa" por "Creta", ilha sob domínio sarraceno (826-961), libertada por Focas, que esquartejou indiscriminadamente a população, incluindo muitas jovens. Este passo é, com outros, um testemunho da época tardia da redacção da obra.

307 "general": o texto tem stratēgétēs ( $\sigma \tau \rho \alpha \tau \eta \gamma \varepsilon \dot{\varepsilon} \eta \varsigma)$, forma que parece só ocorrer nesta obra, em vez de stratēgós ( $\sigma \tau \rho \alpha \tau \eta \gamma o ́ \varsigma)$ — mais uma indicação da época tardia da obra.

${ }^{308}$ A especificação, teu, suscita imediatamente a ideia de não meu!

309 Zeus era filho de Crono e de Reia.

${ }^{310}$ Entenda-se (como se explica abaixo): ... para fazer uma górgone.

311 Refere-se à Górgone...

312 Alusão à primeira união de Zeus com sua irmã (e esposa) Hera; v. Il., XIV, 330-353... 
Por esse deus altíssimo e grande, || deus imortal e celeste ${ }^{313}$, pelo Filho e pelo Espírito \|| ambos do Pai procedentes ${ }^{314}$, um em três e três em um.

Tem esse pelo teu Zeus, || e crê que só esse é Deus ${ }^{315}$.

CRÍCIAS - Estás a ensinar-me a contar, a Aritmética serve para o juramento, e tu contas como Nicómaco de Gérasa ${ }^{316}$. $\mathrm{Na}$ verdade, não sei o que queres dizer com "um em três e três em um". Não te referirás tu ao "quatérnio" 317 de Pitágoras, ou à ogdóade, ou à triácade?

TRIEFONTE -

Silencia o que é oculto $\|$ e é digno de silêncio ${ }^{318}$.

Não se trata aqui de medir as marcas [das patas] das pulgas $^{319}$. Na verdade, vou ensinar-te ${ }^{320}$ que coisa é o Todo, quem é Aquele que existiu antes de todos e o sistema do Universo. Também eu, ainda há pouco, estava na mesma situação que tu, quando aconteceu vir ao meu encontro um tal galileu, calvo no alto da cabeça, de nariz comprido, que tinha voado até ao terceiro céu e [aí] tinha aprendido as mais belas coisas, que nos regenerou pela água, nos guiou na senda dos bem-aventurados e nos resgatou das regióes dos ímpios. Também eu farei de ti, se me deres ouvidos, um homem dedicado à Verdade.

${ }^{313}$ Hexâmetro dactílico (se está certa a emenda moderna dos mss.) do próprio autor.

${ }^{314}$ Dei a esta linha e à seguinte o aspecto métrico, que elas talvez não tenham. Estas duas linhas reflectem o credo de Constantinopla.

${ }^{315}$ Aqui o autor transcreve um verso de Eurípides, de uma tragédia perdida.

316 Nicómaco de Gérasa (cidade da Arábia), c. 100-150 d.C., filósofo pitagórico, músico e matemático, analisou os números numa perspectiva não só estritamente "aritmética”, mas também esotérica: pares, ímpares, primos, e ainda "perfeitos", "amigáveis", "poligonais”, "piramidais”, progressóes, etc.

317 Repito a nota a quatérnion, in Justificação de um Lapso ao Saudar, $\$ 5: \mathrm{O}$ quatérnion, em gr. tetraktǘs ( $\tau \varepsilon \tau \rho \alpha \kappa \rho v ́ \varsigma)$ era o número «10», a soma de $1+2+3+4$, representado por uma figura triangular, em que o vértice tem um (1) ponto, a base quatro (4) pontos e dois níveis intermédios com, respectivamente, dois e três pontos. Os outros dois termos, também de natureza "místico-aritmética" referem-se às propriedades dos números 8 e 30.

318 Verso de autor não identificado.

319 Referência clara ao episódio das Nuvens, $145 \ldots$

${ }^{320}$ Vai, pois, justificar-se o segundo título da obra: $O$ Discípulo. $\mathrm{O}$ cristão Triefonte ensina ao pagáo Crícias alguns mistérios do Cristianismo. 
13. CRÍCIAS — Fala, pois, ó sapientíssimo Triefonte, que já estou a ficar aterrorizado.

TRIEFONTE - Já alguma vez leste a obra As Aves do comediógrafo Aristófanes?

CRÍCIAS - Com certeza.

TRIEFONTE — Está lá gravada a seguinte passagem:

'No começo era o Caos, | a Noite e o negro Érebo | e o dilatado Tártaro: ainda não existiam | nem Terra nem Ar nem Céu. ${ }^{321} \ldots$

CRÍCIAS - Muito bem! E que aconteceu depois?

TRIEFONTE - Fez-se uma luz incorruptível, invisível e incompreensível, que dissipa as trevas e expulsou essa desordem com uma simples palavra dita por Ele, como escreveu o 'tardo de lingua' ${ }^{322}$, que solidificou a terra sobre as águas, expandiu o céu, formou os astros fixos e fixou as órbitas daqueles que tu veneras como sendo deuses, ornamentou a terra com flores, produziu o homem, do não-ser para o ser, e está no céu e vê os justos e os injustos, e escreve em livros as suas acçóes, e a todos dará a [merecida] paga, no dia que Ele fixar ${ }^{323}$.

14. CRÍCIAS — Mas então... aquelas coisas que as Moiras fiaram para todos os homens... também estão lá gravadas?

TRIEFONTE - Que coisas?

CRÍCIAS - As coisas do Destino ${ }^{324}$.

TRIEFONTE - Fala, pois, meu caro Crícias, a respeito das Meras ${ }^{325}$, e eu escutar-te-ei como aluno atento.

CRÍCIAS - Náo foi Homero, o famoso poeta, quem disse

"Afirmo que nenhum homem || ao seu destino fugiu"?326

E a respeito de Héracles:

${ }^{321}$ Aristófanes, Aves, 693-694.

322 Referência a Moisés, que era gago (v. Exxodo, 4.10).

323 Tudo isto alude a passagens bíblicas...

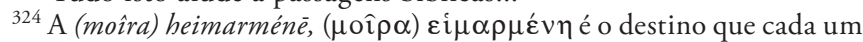
recebe ao nascer, e está representado pelas três Moîrai, port. Meras (Parcas), cujos "decretos" não podem ser contrariados, nem mesmo pelos deuses. Estes, tal como os profetas, somente podem prever o futuro, não anulá-lo. É este aspecto da mitologia greco-romana que o cristão Triefonte vai criticar.

${ }^{325}$ Mera(s) é a adaptação "canónica" ao port.: gr. oi (oi), lat. oe, port. $e$.

${ }^{326}$ Il., VI, 488. 
"Nem fugiu a força hercúlea ${ }^{327}$ || ao seu destino fatal", ele que foi muito amado $\|$ do rei Zeus, filho de Crono, mas a Mera o subjugou, $\|$ e de Hera a raiva cruel.

E também diz que toda a nossa vida e as suas vicissitudes são governadas pelo Destino:

.... mas depois suportará todo o destino que o fado $\|$ mais as cruéis fiandeiras lhe fiaram à nascença, || quando a mãe o deu à luz. ${ }^{328}$ Também a retenção em terra estranha é obra do Destino: E como a casa de Éolo chegámos, I| que tão bem me recebeu, e me apressou, mas meu fado não era $\|$ de chegar à Pátria qu'rida ${ }^{329}$.

Portanto, Triefonte, não queiras acrescentar mais nada a respeito das Meras, mesmo que porventura tenhas sido elevado aos céus na companhia do teu mestre e tenhas sido iniciado nos seus mistérios.

15. TRIEFONTE - Mas então, meu caro Crícias, como é que o mesmo poeta chama "duplo" e ambíguo ao Destino, de maneira que, se uma pessoa procede de certa maneira, obtém um certo resultado, mas, se proceder de outra maneira, tem outro resultado, como no caso de Aquiles [que diz]:

Um destino alternativo || leva-me ao termo da morte: se eu, aqui continuando, || lutar no cerco de Tróia, o meu regresso perece, I| mas terei fama imortal; mas se à Pátria regressar, $\|$... perece a ilustre fama, I| mas longos anos de vida terei... ${ }^{330}$

E a respeito de Euquenor:

Do fim funesto ciente, II embarcara no navio.

Muitas vezes lhe dissera $\|$ o velho e bom Poliido

${ }^{327}$ Il., XVIII, 117-119. Note as hipálages: a força hercúlea $=o$ forte Héracles e de Hera a raiva cruel $=$ Hera cruel e raivosa .

${ }^{328}$ Homero, Od., Vii, 196-198.

329 Ulisses conta a Penélope as suas aventuras e desventuras, os seus errores. Note que os $1^{\text {os }}$ hemistíquios da trad. são em decassílabo, por dificuldade de usar o habitual $7 \| 7$.

${ }^{330}$ Il., IX, 411-416, 
que de doença penosa || no seu paço morreria, ou entre as naus dos Aqueus, || vencido pelos Troianos. ${ }^{331}$

16. Não estấo estas palavras escritas em Homero? Não é isto um embuste ambíguo e perigoso? Se quiseres, também te acrescentarei a palavra de Zeus. Não disse ele a Egisto que estava destinado que, se ele se abstivesse do adultério e da conspiração contra Agamémnon, viveria muito tempo, mas que, se resolvesse levar a cabo essa conspiração, não tardaria a encontrar a morte? Também eu muitas vezes profetizei coisas dessas, por exemplo: se matares o teu próximo, serás condenado à morte pela justiça, mas, se não cometeres esse crime, viverás feliz...

e o termo que é a morte || tão depressa não viráa ${ }^{332}$.

Não vês como as palavras dos poetas são incoerentes, ambíguas e de maneira nenhuma fundamentadas? Portanto, larga tudo isso, para que eles te inscrevam também a ti nos livros celestes dos bons.

17. CRÍCIAS - Voltas sempre ao assunto, ó Triefonte... Mas diz-me cá uma coisa: será que os actos dos Citas também ficam gravados no céu?

TRIEFONTE - Sim, ficam todos, se porventura existirem pessoas boas entre os gentios ${ }^{333}$.

CRÍCIAS - A julgar pelo que dizes, existem muitos escribas no céu, para inscreverem essas coisas todas.

TRIEFONTE - Tem contençấo na língua e não digas mal do Deus hábil, mas, como catecúmeno ${ }^{334}$ que és, acredita em mim, se queres viver por toda a eternidade. Ora, se [Ele] expandiu o céu como uma pele, e consolidou a terra sobre a água, e formou os astros, e criou o homem a partir do nada, que há de estranho no facto de ele registar os actos de todas as pessoas? Realmente, ao construíres uma casinha e ao meteres lá dentro criadas e criados, não te escapa qualquer acto destes, por mais banal que seja. Por maioria de razão, porque é que Deus,

${ }^{331} \mathrm{Il}$., XIII, 665-668.

${ }^{332}$ Homero, Il., IX, 416, do longo discurso de Aquiles.

333 "gentios", sentido hebreu e cristão de éthnos ("ع $\theta \vee \circ \varsigma$ ). Mais um indício de que esta obra não é de Luciano.

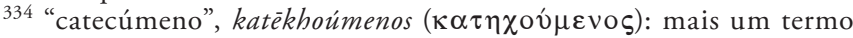
de sentido cristão, como supra. 
que tudo fez, não abrangeria tudo facilmente, [nomeadamente] os actos e pensamentos de cada um [de nós]? Na verdade, para as pessoas bem-pensantes, os teus deuses tornaram-se uma brincadeira de kótabo ${ }^{335}$.

18. CRÍCIAS - Dizes muito bem, e até me puseste na situação contrária à de Níobe ${ }^{336}$. Na verdade, de pedra tumular [que eu era], tornei-me homem. Assim, acrescento-te este deus, não tens nada a recear da minha parte.

TRIEFONTE -

Se me amas de verdade, II do fundo da tua alma ${ }^{337}$,

não faças em mim uma coisa diferente, nem

No peito uma coisa escondas, || e outra tua boca diga.

Mas vamos!, canta-me esse maravilhoso discurso, para que também eu empalideça e fique completamente alterado, e não fique mudo como Níobe, mas me transforme numa ave, como Aédon $^{338}$, para cantar esse teu maravilhoso espanto através desse bosque florido.

CRÍCIAS - Pelo Filho, que procede do Pai! Tal não acontecerá.

TRIEFONTE - Vai falando, tomando do Espírito a força da palavra, e entretanto eu vou sentar-me,

aguardando que o Eácida ${ }^{339}$ | ponha termo ao seu cantar.

19. CRÍCIAS - Caminhava eu pela rua larga, a fim de ir comprar coisas de que tinha necessidade, quando vejo uma enorme multidão de pessoas que segredavam ao ouvido, com

335 O kótabo era um jogo em que se lançavam gotas de vinho numa bacia de metal; pelo som produzido, deduziam-se certas conclusóes amorosas... Aqui significa, em geral, uma brincadeira sem importância.

336 Níobe foi transformada em rocha (não em pedra tumular...).

337 Aristófanes, Nuvens, 86, não exactamente citado (certamente de memória); do mesmo modo, a citação seguinte, Homero, Il., IX, 313. Em ambos os casos, tentei uma versão métrica...

338 Aédon, jovem transformada em rouxinol.

339 "Eácida», «da família de Éaco», pode referir-se, em primeiro lugar, a Peleu, mas também, como aqui, a seu filho, Aquiles. Ilíada, IX, 191. 
os lábios colados às orelhas dos outros. Então eu, olhando com atenção e pondo a mão em concha por sobre as sobrancelhas, procurava de modo muito perscrutador, a ver se descobria algum dos meus amigos. E vejo Cráton, o funcionário público ${ }^{340}$, meu amigo de infância e companheiro de bebida.

TRIEFONTE - Estou a ver, referes-te a esse tal repartidor de impostos. E depois?

20. CRÍCIAS - Então eu, desviando muitas pessoas com os cotovelos, cheguei lá à frente e, dizendo a saudação matinal, corri para ele. Aí, um certo homenzinho, de nome Caríceno, um velhinho gangrenoso e roncando do nariz, tossia lá muito do fundo e mandava longas escarradelas de escarros mais roxos que a morte. A seguir, começou a falar com uma voz esganiçada: "Este, como eu ia dizendo, abolirá os pagamentos atrasados devidos aos repartidores de impostos, pagará as dividas aos credores, bem como todos os alugueres de casas e dividas ao Estado, e aceitará os *eimarángas ${ }^{* 311}$ sem examinar a sua perfeição técnica." E tagarelava coisas ainda mais picantes. As pessoas que o rodeavam divertiam-se com as suas palavras e ficavam suspensas da novidade das suas declaraçóes.

21. Um outro fulano, de nome Cleuocarmo, [vestido] com um manto muito puído, descalço e de cabeça descoberta, meteu-se na conversa, batendo com os dentes; entâo, como que apontando para mim, disse: "Um homem andrajoso, vindo das montanhas, de cabeça rapada, revelou-me o nome gravado no teatro em caracteres hieroglíficos, e que Ele cobrirá de ouro a grande rua."

Então eu, à maneira de Aristandro e de Artemidoro ${ }^{342}$, disse: "Esses vossos sonhos não terão bom resultado, mas, pelo contrário, as tuas dividas engrossarão proporcionalmente ao pagamento

340 "funcionário público", o sentido mais provável de politikós ( $\pi \mathrm{o} \lambda_{\mathrm{l}}$ -

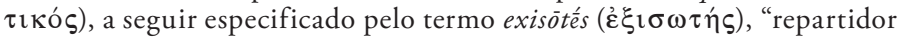
de impostos", lat. peraequator.

341 *eimarángas*, segundo os mss., eimarággas ( $\varepsilon \imath \mu \alpha \rho \alpha ́ \gamma \gamma \alpha \varsigma)$, palavra desconhecida. Segundo Rhode (apud "Loeb”, VIII, 451), poderia tratar-se de uma moeda de ouro persa, aqui metida por Focas, a fim de ridicularizar a personagem. Outras interpretaçóes, baseadas em emendas duvidosas, não são mais convincentes. A interpretação, a seguir, "a sua perfeição técnica" depende da anterior...

${ }^{342}$ Aristandro e Artemidoro, famosos intérpretes de sonhos. 
[prometido], e este indivíduo perderá uma tão grande quantidade de óbolos, como do muito ouro obtido [em sonho]; vós dais-me a impressão de terdes dormido 'sobre a Pedra Branca' e 'no país dos sonhos', e de sonhardes tais coisas num curto instante de uma [longa] noite."

22. Todas as pessoas desataram às gargalhadas a ponto de perderem o fôlego por causa do riso e faziam troça da minha ignorância. Então eu disse a Cráton: "Porventura terei eu tido 'mau faro' - para falar como os cómicos - e não 'segui a pista' dos sonhos, segundo [as normas de] Aristandro de Telmesso e de Artemidoro de Éfeso?"

E disse Cráton: "Cala-te, ó Crícias! Se te mantiveres calado, iniciar-te-ei perfeitamente nos mistérios e nas coisas que estáo agora mesmo para vir. De facto, estas coisas não sâo sonhos, mas coisas verdadeiras, que acontecerão no mês de 'Mesorí3 ${ }^{33}$."

Ao escutar tais palavras da boca de Cráton, e tendo reconhecido a fraqueza do meu pensamento, corei [de vergonha] e retirei-me cabisbaixo, praguejando fortemente contra Cráton. Nisto, um deles, fixando-me com olhar duro e titânico e segurando-me pela ponta do manto, puxou-me com força, tentando convencer-me a um acordo, "picado" pelo tal velho "diabinho"344.

23. Prolongando nós a conversa, convence-me, infeliz de mim, a juntar-me a uns charlatães e a fazer, como sói dizer-se, desse dia um dia nefasto. De facto, dizia ele que tinha sido iniciado em todas as matérias por aqueles homens. Então atravessámos "portas de ferro com umbrais de bronze" ${ }^{45}$. Depois, subimos muitos degraus em caracol, até [chegarmos a] uma sala com tecto dourado, como diz Homero que era a de Menelau. E eu ia observando tudo, tal como o tal jovem ilhéu ${ }^{346}$. Vejo, porém, náo Helena... por Zeus!, mas uns homens de cabeça baixa e extremamente pálidos. "...Entâo eles ao verem [-me]/ muito se

${ }^{343}$ Mês egípcio, correspondente a Agosto.

${ }^{344}$ Referência a Caríceno, $\$ 20$. A designação daimónion ( $\left.\delta \alpha \iota \mu o ́ v ı o v\right)$ tem aqui o sentido, irónico, de "pessoa divinamente inspirada"; também pode ter o sentido que se dá em port. a expressóes como o diabo do homem...

345 Citação de memória, de Il., VIII, 15. Aqui, trata-se da entrada para o Tártaro. Segundo o editor da "Loeb” (VIII, p. 454), pode tratar-se de uma alusão às prisóes do Imperador Focas, onde eram encarcerados os antipatriotas...

346 Alusão a Telémaco e à sua visita ao palácio de Menelau, a fim de saber notícias de seu pai, Ulisses. 
regozijaram" ${ }^{347}$, e vieram ao meu encontro. Não paravam de perguntar se nós trazíamos alguma notícia triste. Na verdade, estes fulanos tinham o ar de pessoas que desejavam as piores desgraças e se regozijavam com notícias tristes, como as carpideiras $^{348}$ nos teatros, e sussurravam com as cabeças muito juntas entre si. A seguir, perguntaram-me:

\section{Quem és? Donde é que vens? Onde é que fica \| [a tua terra e os teus progenitores? ? $^{349}$}

$\mathrm{Na}$ verdade, pareces ser boa pessoa, pelo menos a julgar pela aparência.

E eu respondi: "São realmente poucas as pessoas de bem, como vejo por toda a parte. O meu nome é Crícias, e sou da mesma cidade que vós."

24. E como habitantes das nuvens, perguntavam: "Como vão as coisas na cidade... e no mundo?"

E eu respondi: "Todos estão felizes, e ainda ficarão mais felizes."

E eles franziam as sobrancelhas, contrariados ${ }^{350}$ : "Não é assim, pois a cidade está a chocar algo de mau."

E eu disse, a favor da sua opinião: "Vós, que viveis nas alturas, e como pessoas que vedes tudo do alto, percebeis tudo da maneira mais penetrante. Então como vão as coisas no céu? Será que o Sol ${ }^{351}$ vai eclipsar-se? Ou a Lua vai estar na vertical? Será que Marte vai estar em quadratura com Júpiter? E Saturno vai estar em oposição ao Sol? Será que Vénus vai estar em conjunção com Mercúrio e [ambos] gerarão Hermafroditos ${ }^{352}$ com que vós tanto vos comprazeis? Será que iráo enviar-nos chuvas torrenciais? Ou cobrirão a terra de grande quantidade de neve, ou mandarão cá para baixo granizo e ferrugem da vinha? Mandaráo peste, fome

${ }^{347}$ Homero, Il., XXIV, 320-321, mas em Homero trata-se da visão da águia de Zeus.

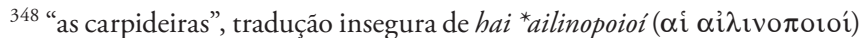
(emenda do ed. da "Loeb" (VIII, p.454); outros propóem hai poinopoioi ( $\alpha i$

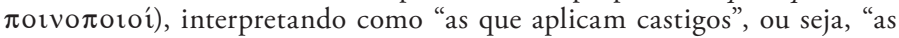
Fúrias (vingadoras)".

${ }^{349}$ Homero, Od., I, 170.

${ }^{350}$ A ideia de "contrariados" está incluída no verbo ananeúo ( $\alpha$ $\left.\alpha \nu \varepsilon v ́ \omega\right)$.

${ }^{351}$ Os nomes dos astros segue, naturalmente, o uso latino.

${ }^{352}$ Hermafrodito era filho de Hermes (Mercúrio) e Afrodite (Vénus). 
e seca? Irá ser despejado o vaso que lança o raio? Será que vai ser novamente cheio o recipiente que lança os trovóes?"

25. Eles, porém, como pessoas muito convencidas de tudo, tagarelavam a respeito das matérias da sua predilecção, dizendo que as coisas estavam a mudar, que as desordens e os tumultos iriam apoderar-se da cidade e que as nossas tropas seriam vencidas pelos inimigos. Aí eu, muito perturbado e inchado como um carvalho verde incendiado, gritei-lhes com voz penetrante: "Ó tipos danados, não faleis com essa grande prosápia, 'afiando os dentes contra homens de coração de leão, que respiram lanças e dardos e elmos de alvos penachos. ${ }^{353}$ Mas essas desgraças cairáo sobre as vossas cabeças, pois tentais enfraquecer a vossa Pátria. Realmente, não foi nas vossas viagens aéreas que vós ouvistes essas coisas, nem o conseguistes através da muito trabalhosa Astrologia ${ }^{354}$. Se foram as profecias e as charlatanices que insidiosamente vos induziram em erro, a vossa ignorância é dupla. Na verdade, tudo isso não passa de invençóes de velhas e de infantilidades. Sim, geralmente são os espiritos imaginativos das mulheres que se entregam a tais actividades."

26. TRIEFONTE - E então, meu caro Crícias, que é que esses fulanos, "tosquiados" de bom senso e de inteligência, responderam a essas tuas palavras?

CRÍCIAS - Passaram por cima delas e refugiaram-se num plano muito habilidoso. De facto, disseram: "Permaneceremos dez sóis em jejum, e então, depois de passarmos noites inteiras de vigília a cantar hinos, sonharemos sobre esses temas."

TRIEFONTE - E que é que tu lhes respondeste? Realmente, deram-te uma resposta importante e embaraçosa.

CRÍCIAS - Fica tranquilo, não me acobardei, mas respondi da melhor maneira, dizendo: "É o que se murmura pela cidade a vosso respeito: que essas desgraças só ocorrem nos vossos sonhos."

Então eles, sorrindo abertamente, disseram: "Também ocorrem fora do leito."

E disse eu: "Se isso é verdade, ó criaturas aéreas, nunca poderieis adivinhar of futuro com segurança, porquanto, ao deixar-vos

${ }^{353} \mathrm{O}$ autor reúne de memória três passos das Rãs, de Aristófanes (parte dos vv. 815, 1016 e 1041).

354 "Astrologia": o gr. diz mathēmatikè ( $\mu \alpha \theta \eta \mu \alpha \tau \imath \kappa \eta ́)$, termo geral que chegou a abranger a Matemática, a Aritmética, a Geometria, a Mecânica, e, enfim a Astronomia e a Astrologia. 
persuadir por esses [sonhos], estareis a fantasiar sobre coisas que não existem nem existirão. Não sei lá porquê, fantasiais essas tolices, acreditando em sonhos, odiando as mais belas coisas e regozijando-nos com as más, sem tirardes qualquer beneficio do vosso ódio. Portanto, abandonai essas fantasias bizarras, essas ideias perversas e essas vossas profecias, não se dê o caso de Deus vos punir por falardes mal da vossa Pátria e dizerdes palavras de man agoiro."

27. Então todos eles, num só espírito, lançaram censuras sobre a minha pessoa. Se tu assim o desejares, acrescento também essas palavras, que me deixaram mudo como uma coluna funerária... até que o teu precioso chamamento ${ }^{355} \mathrm{me}$ tirou do estado petrificado e voltou a fazer de mim um ser humano.

TRIEFONTE - Cala-te, ó Crícias, e não insistas nessas patacoadas. Estás a ver como tenho a barriga inchada ${ }^{356}$, como se estivesse grávido. De facto, fui mordido pelas tuas palavras, como se fosse por um câo raivoso. E se não me acalmar, ingerindo uma droga olvidante, esta recordação, ao instalar-se em mim, causar-me-á um grande mal. Portanto, esquece essas palavras ${ }^{357}$, começando com a oração do $\mathrm{Pai}^{358}$ e acrescentando, no fim, a ladainha cantada...

28. ... Mas... que é isto? Este aqui não é Cleolau, que avança com passos largos e vai com pressa para entrar em casa? Chamamo-lo?

CRÍCIAS - Sim, claro.

TRIEFONTE - Cleolau!

Não passes por nós correndo, \|não sigas o teu caminho, mas vem cá alegremente, || se trazes alguma nova. ${ }^{359}$

CLEOLAU — Bom dia a ambos, o belo par!

TRIEFONTE - Mas que pressa é essa, que te faz ficar sem fôlego? Será que há alguma novidade?

355 Referência ao início do diálogo, $\$ 1$.

356 "inchada", entenda-se... das patacoadas.

357 "essas palavras" ou "esses fulanos", a mbas as interpretaçóes permi-

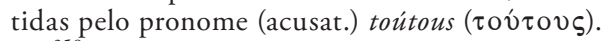

358 Trata-se do Pai-Nosso.

${ }^{359} \mathrm{O} 1^{\circ}$ verso pretenderia ser um hexâmetro, com algum eco de Hom., Od., VIII, 230); o 2o é um trímetro jâmbico de autor desconhecido. 


\section{CLEOLAU}

Caiu dos Persas a sobranceria, I| desde há muito tão gabada, também de Susa a ilustre fortaleza;

de igual modo cairá || toda a terra da Arábia,

às mãos e sob o poder $\|$ tremendo do vencedor. ${ }^{360}$

29. CRÍCIAS - É bem certo que a divindade nunca abandona os bons, mas eleva-os, conduzindo-os a melhor situação. Quanto a nós, ó Triefonte, encontrámos o melhor de tudo. $\mathrm{Na}$ verdade, eu estava preocupado com o que, ao abandonar esta vida, deixaria em testamento aos meus filhos... Tu conheces a minha pobreza, como eu conheço a tua. Ora, para os meus filhos bastam os [longos] dias [de vida] do Imperador, pois não nos faltará riqueza, e nenhuma nação nos meterá medo.

TRIEFONTE - Também eu, ó Crícias, deixarei isso aos meus filhos, a saber, que vejam Babilónia destruída, o Egipto escravizado, os filhos dos Persas reduzidos à escravidão, a cessação das invasóes dos Citas... prouvera que terminadas para sempre! Então nós, que encontrámos e adorámos o "[Deus] Desconhecido" de Atenas, elevemos as nossas mãos ao céu e demos graças a Ele, por termos sido dignos de nos tornarmos súbditos deste Império. E quanto aos outros fulanos, deixemo-los fantasiar, e contentemo-nos com dizer aquele provérbio: "Hipoclides náo liga a isso." 361

${ }^{360}$ Há nestes versos (alguns muito deficientes) ecos de obras "clássicas". Os inimigos aqui nomeados devem levar directamente aos Sarracenos, inimigos do Império Bizantino.

${ }^{361} \mathrm{O}$ episódio é relatado por Heródoto, VI, 126-131. Resumidamente, Hipoclides, que havia sido escolhido por Clístenes, tirano de Sícion, para marido de sua filha, comportou-se de tal maneira numa dança, que o tirano desistiu da escolha, ao que Hipoclides deu a famosa resposta, que passou a provérbio. 
Nero [ou A Abertura do Istmo] 
(Página deixada propositadamente em branco) 


\section{INTRODUÇẤO}

Embora três manuscritos ( $\mathrm{N}$ e outros dois) atribuam este diálogo a Luciano, os críticos consideram seu verdadeiro autor um dos Filóstratos, talvez Verus Philostratus, um filósofo sofista do séc. II d.C., que o editor da "Loeb" não hesita mesmo em indicar como seu autor. O leitor encontrará um bom resumo desta problemática na ed. "Loeb”, VIII, pp. 505-507.

Trata-se de um curto diálogo, imaginado entre o filósofo estóico Musónio e um tal Menécrates, que alguns identificam com um tocador de lira favorito de Nero, o que torna algumas das suas intervençôes pouco convincentes... mas isso pode dever-se a uma natural imprecisão do autor do diálogo. Musónio, no entanto, é bem conhecido como um dos perseguidos de Nero, que o desterrou para a desolada ilha de Gíaros (ou esta foi o lugar de exílio escolhido pelo filósofo).

Menécrates vai, pois, visitar Musónio, a fim de se informar dos motivos que levaram Nero a pretender abrir o Istmo de Corinto. De passagem - passagem que, a par do tema inicial, que se torna em assunto central —, fala-se das qualidades vocais de Nero, matéria em que vemos o desejo, por parte de Musónio, de ser imparcial: Nero não seria um génio, mas possuía algumas qualidades...

O diálogo termina com a boa nova da morte do tirano, pelo que a acção (não a data de composição do diálogo) se situa no ano de 68 d.C., na ilha de Gíaros. Sabemos que Musónio, morto o tirano, regressa a Roma, bem acolhido por Vespasiano. 
(Página deixada propositadamente em branco) 


\section{Nero ou [A Abertura do Istmo]}

1. MENÉCRATES - Na tua opinião, ó Musónio - já que, segundo se diz, tomaste parte na obra com as tuas próprias máos -, teria a abertura do Istmo sido inspirada ao tirano por uma ideia Grega?362

MUSÓNIO - Fica sabendo, ó Menécrates, que Nero tinha idealizado uma coisa ainda superior. Realmente, com aquele rasgo do Istmo, de vinte estádios ${ }^{363}$, poupava aos marinheiros o circuito do Peloponeso e a passagem pelo cabo Málea. E esse facto teria favorecido ${ }^{364}$ não só o comércio, mas também as cidades costeiras e até as do interior, na medida em que estas [últimas] obteriam os produtos necessários ao país, se o litoral fosse próspero.

MENÉCRATES - Conta lá essa coisa, ó Musónio, pois desejamos ${ }^{365}$ escutar tudo em pormenor... se náo estiveres a pensar noutro assunto urgente.

MUSÓNIO - Pois vou contar, já que assim o desejais. Na verdade, não sei melhor maneira de obsequiar quem com tanto zelo se deslocou a esta táo desagradável escola de Filosofia ${ }^{366} \ldots$

2. ... Ora, as artes do canto costumavam levar Nero à Acaia ${ }^{367}$, bem como o facto de estar firmemente convencido de que nem as próprias Musas cantavam mais docemente. Pretendia ele ser coroado vencedor no canto, em Olímpia o mais atlético de todos os Jogos ${ }^{368}$. De facto, no respeitante aos [êxitos] píticos, achava-se com mais direitos que o próprio

${ }^{362} \mathrm{O}$ texto é algo complicado. Embora mais adiante (\$3) se diga que Nero deu as primeiras três cavadelas, no parágrafo seguinte vê-se que Musónio tomou parte no início das obras, deixando o resto para prisioneiros, entre os quais parece ter estado o filósofo estóico Musónio, caído em desgraça...

363 c. $3,5 \mathrm{~km}$.

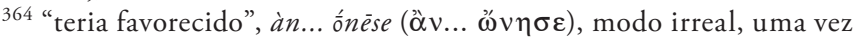
que a obra náo se concretizou.

365 Não deve tratar-se de plural majestático, pois é de supor que Menécrates fosse acompanhado...

366 "escola de Filosofia”, ou, à maneira das Nuvens de Aristófanes, phrontistêrion ( $\left.\varphi \rho \circ \tau_{\tau} \sigma \tau \hat{\rho} \rho \imath o v\right)$, "lugar de meditação"... "pensadoiro" (cf. bebedoiro...). Musónio, após a sua expulsão de Roma, por Nero, estabelecera-se em Gíaros, ilha desolada entre as Cíclades.

367 "Acaia", neste contexto, era a província romana que abrangia toda a Grécia, menos a Macedónia, pelo que bem poderíamos traduzir, também, por "Grécia”.

368 Segundo Suetónio, foi precisamente Nero quem introduziu nos Jogos Olímpicos concursos de canto e música. 
Apolo, pois considerava que este deus não se comparava com ele, tanto na lira como no canto. Quanto ao Istmo, desde há muito que náo fazia parte dos seus planos, mas apaixonou-se por uma obra grandiosa, não só perante a natureza do lugar, mas também lembrado do rei dos Aqueus no cerco de Tróia, o qual separou a Eubeia da Beócia por meio do [estreito de] Euripo, junto a Cálcis, e [lembrado] também de Dario, que construiu uma ponte sobre o [estreito do] Bósforo, para atacar os Citas, e também pensou nas obras mais grandiosas de Xerxes $^{369}$ e talvez noutras antes destas, e que, além disso, pelo facto de todos comunicarem rapidamente uns com os outros, seria possível fazer da Grécia um país de acolhimento de estrangeiros. Na verdade, é da natureza dos tiranos deixarem-se inebriar, sequiosos de escutar elogios deste género.

3. Entáo Nero, saindo da sua tenda, cantou um hino em honra de Afrodite e de Posídon e uma breve cantiga dedicada a Melicertes e Leucótea ${ }^{370}$. E logo que o governador da Grécia ${ }^{371}$ lhe apresentou uma enxada de ouro, atirou-se com afinco à escavação, no meio de aplausos e cantos, mas, depois de dar, creio eu, três cavadelas, e de exortar os encarregados da escavação $0^{372}$ a que se atirassem ao trabalho com energia, foi para Corinto, convencido de ter ultrapassado todos os trabalhos de Héracles. Então, enquanto os prisioneiros trabalhavam afanosamente nas zonas pedregosas e em [outros] trabalhos penosos, os soldados [faziam-no] em solo terroso e plano...

4. Estávamos nós há cerca de setenta e cinco dias ${ }^{373}$ "amarrados" 374 ao Istmo, quando desceu de Corinto uma notícia,

${ }^{369}$ Xerxes abriu um canal no istmo de Atos, com uma técnica descrita por Heródoto, VII, 21, ss.

${ }^{370}$ Melicertes e Leucótea divindades marinhas, como Posídon e Afrodite, "nascida das ondas".

371 V. $\$ 2$, nota a "Acaia”.

372 "escavação": aceito a emenda de Peletier (apud "Loeb”, VIII, p. 512),

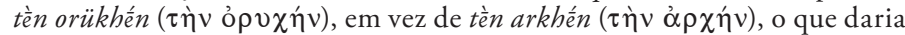
(com alguma dificuldade) "os encarregados de começar...".

373 "setenta e cinco dias": os mss. dizem “... no sétimo e... quinto”, o que náo dá sentido.

374 “amarrados”, gr. (gen. pl.) prosezeugménōn $(\pi \rho \circ \sigma \varepsilon \zeta \varepsilon v \gamma \mu \varepsilon \dot{v} \omega \omega)$ : é, pois, de supor que o filósofo Musónio havia sido não só exilado, mas, naquela ocasião, posto em trabalhos forçados. 
ainda insegura, de que Nero tinha mudado de opinião a respeito do Istmo. Dizia-se que os geómetras egípcios tinham calculado as condiçốes de cada um dos mares, e eles não estavam [ambos] ao mesmo nível, mas julgavam que o mar do lado de Lequeu ${ }^{375}$ estava a um nível superior, pelo que temiam pela sorte de Egina, caso um mar tão violento se lançasse sobre a ilha e Egina fosse arrastada sob as águas. Mesmo assim, nem o próprio Tales, o maior sábio e o mais conhecedor da Natureza, teria feito com que Nero mudasse de opiniáo a respeito da abertura do Istmo. E que ele estava ainda mais apaixonado pela abertura do estreito do que pelo canto...

5. ... Todavia, a sublevaçáo dos povos Ocidentais, bem como o facto de um homem muito animoso, de nome Víndex ${ }^{376}$, ter recentemente aderido a ela, afastaram Nero da Grécia e do Istmo, com um pretexto friamente geométrico. $\mathrm{Na}$ verdade, eu sei que os dois mares estáo ao mesmo nível de terra e ao mesmo nível entre si. Também se diz que a situação em Roma está algo periclitante para Nero, e que ele está receoso. Foi isso mesmo que vós ouvistes ontem da boca de um tribuno militar ${ }^{377}$ que abordou aqui.

6. MENÉCRATES — Mas, ó Musónio, [diz-me cá] como é a voz do tirano, que o torna louco pela música e apaixonado pelas vitórias olímpicas e píticas. É que, realmente, de entre os que aportam a Lemnos, uns admiram-na, enquanto outros troçam dela.

MUSÓNIO - Bem... ó Menécrates, o homem não é [neste aspecto] nem digno de admiração nem de troça. De facto, a natureza dotou-o sem grandes reparos e de maneira mediana. A sua $v^{378}$ é por natureza cava e grave, pois a sua garganta é assim conformada e, nesta conformidade, a voz sai um tanto rouca. No entanto, os tons de voz saem mais suaves, quando ele

375 Lequeu, Lequeias ou Lequias, três adaptaçôes possíveis. Pequena localidade, do lado do Golfo de Corinto, que servia de porto a esta cidade.

376 Víndex, procurador da Gália, revoltou-se contra Nero. Nota: a grafia Bindax $\left(\mathrm{B} i ́ v_{\delta} \alpha \xi\right)$ denota uma cópia bizantina, que nada prova a respeito da data da obra...

${ }^{377} \mathrm{O}$ gr. traduz por khiliarkhos ( $\chi \imath \lambda i \alpha \rho \chi 0 \varsigma$ ) o lat. tribunus militaris ou tribunus militum. Cada legião tinha seis oficiais que a comandavam, cada um durante dois meses. Tratava-se, pois, de um cargo importante.

378 Segue-se uma apreciação das qualidades artísticas de Nero, com uma terminologia algo difícil de perceber e, portanto, de traduzir. 
não os força demasiado, mas sim com a suavidade dos meios-tons, com a fluidez da melopeia, com um ligeiro acompanhamento de lira, com o movimento no devido tempo, ora parando, ora mudando de lugar e com o gesto sincronizado com a música... enfim, uma só coisa tem o seu quê de vergonhoso: que um rei se mostre tão desejoso de parecer perfeito nesta actividade.

7. Quando Nero tenta imitar os grandes, que risota vem do lado dos espectadores, ainda que muitos receios impendam sobre a cabeça de quem quer que faça troça dele! O homem agita a cabeça mais do que é decente, sustém a respiração, póe-se em bicos dos pés, curvando-se para trás como as pessoas atadas a uma roda ${ }^{379}$. Sendo muito corado por natureza, fica ainda mais vermelho, com o rosto todo inflamado. O seu fôlego é curto e de maneira nenhuma suficiente.

8. MENÉCRATES - Mas então, ó Musónio, como é que os seus adversários lhe cediam a vitória? Certamente que lha oferecem por meio de artifício.

MUSÓNIO - Sim, por meio de artifício, como os lutadores que se deixam vencer. Lembra-te, ó Menécrates, daquele actor de tragédia e de como ele morreu no Istmo. De facto, os riscos das artes e dos artifícios ${ }^{380}$ são iguais, se os seus "artistas" levarem a sua acção demasiado longe.

MENÉCRATES - Que caso foi esse, ó Musónio? É que nunca ouvi falar dessa história.

MUSÓNIO — Escuta lá então a história, realmente estranha, mas passada à vista de gregos...

9. ... Foi o caso que, apesar de ser uma lei estabelecida no Istmo, que proíbe os concursos de comédia e de tragédia, Nero resolveu vencer aí actores trágicos. Então compareceram a esse certame muitos [actores], entre os quais um epirota, senhor de uma excelente voz, muito aplaudido e admirado por esse facto, o qual fingia mais abertamente que de costume que desejava a coroa, dizendo que não se deixaria vencer, sem que Nero

${ }^{379}$ Trata-se de um instrumento de tortura, que aqui sugere a figura de Ixíon, um dos grandes torturados da Mitologia.

380 "artes e... artifícios" tenta traduzir os dois sentidos de (acusat. pl.) tékhnas ( $\tau \dot{\varepsilon} \chi \vee \alpha \varsigma)$, em que com o plural se pretende sugerir essas dois sentidos. 
lhe desse dez talentos pela vitória. Nero ficou muito irritado e numa autêntica fúria. Na verdade, tinha-o ouvido falar assim na parte inferior da cena, mesmo no momento da representação. Ora, como os gregos gritassem em favor do epirota, mandou o seu secretário, ordenando ao outro que lhe cedesse a vitória. Como este, porém, elevasse ainda mais a voz e rivalizasse com Nero como se este fosse um simples popular, [o Imperador] manda subir ao estrado os seus próprios actores, como se eles pertencessem à acção. Então os homens, empunhando placas de marfim de duas folhas, como se fossem punhais, apertaram o epirota contra a coluna próxima e cortaram-lhe a garganta, ferindo-o com as placas em riste.

10. MENÉCRATES - Então, ó Musónio, Nero obteve a vitória na tragédia, depois de cometer um crime abominável aos olhos dos Gregos?

MUSÓNIO - Isso foi uma brincadeira para um jovem ${ }^{381}$ que já tinha assassinado a própria mãe. Haverá algum motivo de espanto por ele ter assassinado um actor de tragédia, cortando-lhe a voz? Na verdade, até se propôs obstruir o antro do [Apolo] Pítio, de onde se desprendiam os sons proféticos, para que Apolo ficasse sem voz, apesar de o Pítio o ter considerado ao lado de Orestes e de Alcméon, aos quais o matricídio deu até algum motivo de glória, pelo facto de terem vingado os respectivos pais. Nero, porém, não podendo de maneira nenhuma dizer quem é que vingara, considerou que fora insultado pelo deus, mesmo escutando algo mais suave que a verdade...

11. ... Mas... enquanto nós falávamos... que navio é aquele que se aproxima? Como parece trazer alguma boa notícia! As pessoas têm coroas nas cabeças, como um coro de bom augúrio, e alguém, lá da proa, estende a mão, exortando-nos a ter coragem e a rejubilar, e está a gritar, se bem oiço, que Nero morreu.

MENÉCRATES - Sim, Musónio, é isso que a pessoa grita, e de cada vez mais audível, à medida que se aproxima de terra. Que felicidade, ó deuses!

MUSÓNIO - Mas não dêmos acções de graças, pois diz-se que não se deve fazer isso pelos mortos.

${ }^{381} \mathrm{O}$ jovem era Nero, que aos 22 anos mandou assassinar sua mãe, Agripina. 
(Página deixada propositadamente em branco) 


\section{O Pseudo-sofista ou O Solecista}


(Página deixada propositadamente em branco) 


\section{INTRODUÇẤO}

A palavra sofista refere-se, no tempo de Luciano, ao "intelectual". Este, porém, o do diálogo, é um "falso intelectual", um ignorante que pretende fazer-se passar por intelectual, neste caso, no domínio da língua e do seu purismo aticista. O subtítulo da obra, O Solecista, refere-se precisamente à mesma personagem... que comete solecismos, ou seja, erros de gramática e de língua (sintaxe, léxico, morfologia, semântica...).

Diga-se, desde já, que se trata de uma obra praticamente impossível de verter para qualquer outra língua, pois trata de pormenores específicos da língua grega, que geralmente não têm correspondência noutros idiomas. As notas de rodapé explicarão, na medida do possível, onde está o solecismo. $\mathrm{Na}$ verdade, este texto seria uma boa base para uma longa série de aulas de Língua Grega, e certamente constituiria matéria do ensino do gramático, para que os meninos ou os adolescentes (e não só!) aprendessem e fixassem as boas normas da linguagem. Mas, para o leitor pouco ou nada conhecedor de grego, a sua leitura torna-se altamente fastidiosa. Por isso o deixei para o fim... antevendo penosamente as dificuldades, ou melhor, as impossibilidades...

Esta obra é literariamente extremamente pobre: os exemplos de solecismos, que, aparentemente, surgem ao sabor da conversa, são, na realidade, procurados, muitas vezes sem virem na sequência natural do diálogo. Em todo o caso, o Pseudo-sofista tem um certo valor didáctico aplicado à época (supostamente) de Luciano, em que a koinế popular afectava muitos escritores, mesmo alguns que se reclamavam do aticismo. Justamente por esse valor e esse propósito didácticos (e dada até a sua pouca qualidade literária), imagino que o Autor, guardiáo da pureza da língua, poderia muito bem proceder como o gramático latino Probo, o qual, na sua Appendix, faz uma lista de vocábulos usados popularmente, que ele recomenda que sejam substituídos pelos "correctos", como, p.ex.: (diga-se) equus, non caballus. Assim, esta obra didáctica poderia, com mais proveito, apresentar-se mais ou menos assim:

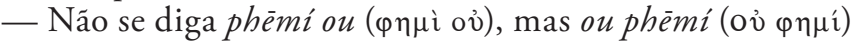
["digo que não", "nego": v. nota a não afirmas, \$1];

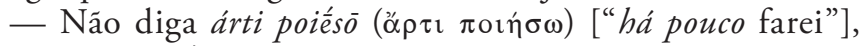

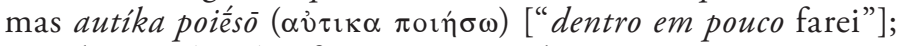

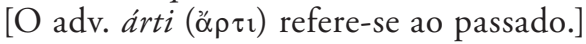




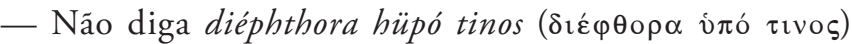
[“corrompi por algo / por alguém”], mas diephthárēn hüpó

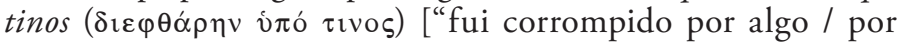
alguém”]. [O perf. diéphthora é activo-transitivo, pelo que não pode construir-se com o agente da... passiva; o seu complemento seria ti / tina $(\tau \imath / \tau \imath v \alpha)$.]... Etc.

Por esta amostra, vê-se logo que a tradução de um texto como este, de feição primordialmente gramatical e didáctica, se torna bastante difícil e, em muitos casos, mesmo impossível. O leitor que tenha a paciência (se tiver!) de ler o texto e as respectivas notas, compreenderá como foi penosa para o... "tradutor" (!) a "versão" (!) portuguesa do Pseudo-sofista ou O Solecista.

Os manuscritos divergem na nomeação das duas personagens deste diálogo: LUCIANO e um SOFISTA; LICINO e o SOLECISTA. Sem discutir o caso, seria, de certo modo, estranho que Luciano, contrariamente ao seu hábito, se colocasse a si mesmo como personagem do diálogo, o que sugere que alguém, tomando-o como um modelo de correcção linguística, imaginasse uma cena em que Luciano surge como mestre do bom uso da língua.

Além deste argumento, alguns críticos negam a autoria de Luciano, considerando, por um lado, que a obra não está à altura do seu talento, e, por outro lado, o facto de alguns dos "solecismos" apontados constarem de obras de Luciano.

Sugiro que a personagem "LUCIANO" seria a "legítima", que alguns copistas, arbitrariamente, teriam substituído pela habitual "LICINO", que em muitos diálogos surge nitidamente como o interlocutor que defende as posições de Luciano. O contrário ("LICINO" substituído por "LUCIANO") seria pouco aceitável.

Os manuscritos também divergem na nomeação da outra personagem, o que pode dever-se ao próprio título do diálogo: O Pseudo-sofista ou O Solecista. Sem mais discussão, sigo a ed. "Loeb" (VIII). 


\section{O Pseudo-sofista ou O Solecista}

1. LUCIANO - Será que aquele que é especialista em assinalar quem comete solecismos, esse mesmo também é capaz de evitar ele próprio os solecismos?

SOFISTA - A mim parece-me que sim.

LUCIANO - E então aquele que não é capaz de os evitar, será incapaz de assinalar quem assim procede?

SOFISTA - É verdade o que dizes.

LUCIANO - E tu próprio não afirmas cometer ${ }^{382}$ solecismos... ou que é que diremos a teu respeito?

SOFISTA - Na verdade, eu seria muito ignorante, se, nesta minha idade, cometesse solecismos.

LUCIANO - Portanto, serás capaz de surpreender uma outra pessoa que assim proceda e de refutar quem negue o facto?

SOFISTA - Absolutamente.

LUCIANO - Então vejamos... apanha-me lá a cometer um solecismo... que já cometerei ${ }^{383}$.

SOFISTA - Ora diz lá.

LUCIANO - Mas eu acabo de cometer esse erro, e tu não o reconheceste!

SOFISTA - Estás a brincar?

LUCIANO - Náo, pelos deuses! De facto, sem tu dares por isso, cometi um solecismo... tu é que não o reconheces. Repara novamente: Eu afirmo que tu não és capaz de perceber... umas coisas sabes, outras coisas ${ }^{384}$ não sabes.

SOFISTA — Diz lá então.

LUCIANO - Mas ainda agora acabei de cometer um solecismo... tu é que não o reconheceste...

382 "não afirmas cometer", em vez de (em port.!) “afirmas não cometer": em gr. "correcto", “eu digo que náo..." diz-se "eu não digo que...", ou seja, ou phèmí (ov̉ $\varphi \eta \mu i ́)$, e não phèmí ou ( $\varphi \eta \mu$ í o v̉). É claro que a versão port. deixa muito a desejar... como acontecerá com quase todas as outras que se seguem.

${ }^{383} \mathrm{O}$ adv. árti (ó $\left.\rho \tau \imath\right)$ refere-se ao passado, mesmo ao passado recente, e não ao futuro, como se, em vez de port. há pouco... fizemos, disséssemos há pouco... faremos; o adv. port. já presta-se a ambos os usos... mas sem solecismo!

384 "umas coisas... outras coisas": no port. não há solecismo (nem maneira de o inventar!), mas é preciso dizer que, segundo a boa norma (que o próprio Luciano transgride em certos passos de outras obras), náo deveria dizer-se

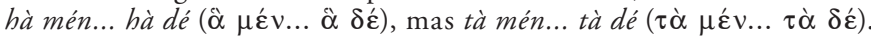


SOFISTA - Como é isso, se tu não disseste nada?

LUCIANO - Eu falo e [ao falar] cometo um solecismo... tu é que não me acompanhas quando eu assim procedo. Oxalá viesses a poder neste momento ${ }^{385}$ acompanhar-me.

2. SOFISTA -É espantoso o que dizes... que eu não serei capaz de reconhecer um solecismo.

LUCIANO - E como é que poderias reconhecer um só [que fosse], depois de teres ignorado três?

SOFISTA - Quais três?

LUCIANO - Todas as... "recém-barbeadas"386.

SOFISTA - Creio que estás a brincar comigo.

LUCIANO - E eu [creio] que tu não sabes quando uma pessoa comete um erro de linguagem.

SOFISTA - E como é que se pode saber tal coisa, se nada foi dito?

LUCIANO - Foram ditos solecismos, e até em número de quatro, e tu não os reconheceste... Sim, terias conseguido grandios $\underline{0} \ldots$ façanh $\underline{a}^{387}$, se porventura os reconhecesses.

SOFISTA - Nada de grandioso, mas indispensável para poder concordar.

LUCIANO - Mas é que nem agora os reconheceste...

SOFISTA - Agora quando?

LUCIANO - Quando eu disse que tu tinhas conseguido uma façanha...

SOFISTA - Não percebo o que queres dizer...

LUCIANO — Dizes bem: não percebes. Então avança mais adiante, uma vez que não queres seguir-me, embora poderias perceber $^{388}$. se quisesses.

${ }^{385} \mathrm{O}$ gr. óphelon (ó $\varphi \varepsilon \lambda \mathrm{ov}$ ) não se constrói regularmente com o futuro do indicativo, além de que a forma correcta seria a $2^{a}$ p. sg. ópheles (ó $\varphi \varepsilon \lambda \varepsilon \varsigma)+$ infinitivo. É complicado verter para port.!

386 "recém-barbeadas" ou "de barba a despontar", artigeneious ( $\alpha \rho \tau \imath$ $\gamma \varepsilon v \varepsilon i ́ o v \varsigma)$, em vez de artigeneîs ( $\alpha \rho \tau \imath \gamma \varepsilon v \varepsilon \hat{\imath} \varsigma$ ) "recém-nascidas", ou seja, os três últimos exemplos: linguagem realmente obscura...

387 Versão necessariamente infeliz: O termo para "façanha" é âthlos

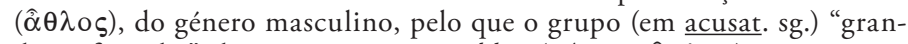

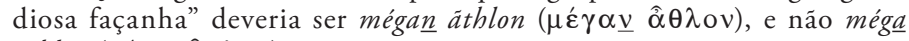
ãthlon ( $\mu \varepsilon \dot{\varepsilon} \underline{\alpha} \hat{\alpha} \theta \lambda o v)$.

${ }^{388}$ A frase é complicada, mas o solecismo parece estar no uso de án

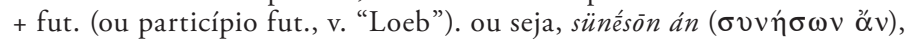
em vez do part. pres. ou aor. (v. "Loeb”, VIII, p. 12). A versão port. é, mais uma vez, de recurso... 
3. SOFISTA - Mas é que eu quero mesmo. Mas tu não disseste nada daquilo que as pessoas dizem ao cometerem solecismos.

LUCIANO - Então o que eu disse parece-te constituir uma pequena falta? Nesse caso, segue-me outra vez, já que náo te apercebeste de eu me ter transviado.

SOFISTA - Não, pelos deuses!, não me apercebi.

LUCIANO - Eu é que deixei a "lebre" correr 389 muito depressa. Terei corrido de mais? Mas agora já é possível ver a "lebre". Caso contrário, muitas "lebres" que caíram em solecismo te passarão despercebidas.

SOFISTA - Não passarão, não.

LUCIANO - No entanto, já passaram.

SOFISTA - Espanta-me o que estás a dizer.

LUCIANO - E que pela tua própria erudição perdeste $e^{390}$, de tal maneira, que não te apercebeste de estares a cometer

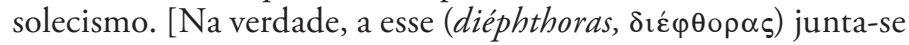
(o complemento) tina "alguém"] 391

4. SOFISTA - Náo percebo o que queres dizer com isso, mas apercebi-me de que muitas pessoas cometem tais solecismos...

LUCIANO - Mas terás consciência disso a meu respeito, quando te tornares um desses "meninos de mama" que chucham nas [tetas das] $\operatorname{amas}^{392}$. Se tu agora não reconheceste que eu estava a cometer solecismo, também os meninos, à medida que vão crescendo ${ }^{393}$, farão solecismos perante quem não os detecta.

SOFISTA - É verdade o que dizes.

${ }^{389}$ Há aqui duas faltas: o acusat. lagō $(\lambda \alpha \gamma \omega \dot{)})$ em vez de át. lagōn $(\lambda \alpha \gamma \omega \dot{v})$, e logo a seguir; também theîn $(\theta \varepsilon \hat{\imath} v)$, em vez de át. théein $(\theta \dot{\varepsilon} \varepsilon \imath)$. Quem quer ser aticista, respeite o dialecto! Note, entretanto, que as três citações da lebre são em sentido figurado.

390 "perdeste" é a traduçáo do perfeito activo transitivo diéphthoras ( $\delta 1 \varepsilon \varphi \theta 0 \rho \alpha \varsigma)$, em vez do aoristo passivo-reflexo diephthárēs ( $\delta 1 \varepsilon \varphi \theta \alpha \dot{\rho} \eta \varsigma)$ "te perdeste".

${ }^{391}$ Algum copista, seguido por outros, resolveu inserir a explicação do solecismo (v. nota supra).

392 Traduzindo a linguagem figurada, Luciano (Licino?) sugere que o seu interlocutor ainda tem muito que "mamar" (aprender) na escola dos gramáticos. É praticamente impossível verter os dois sentidos de thélázo

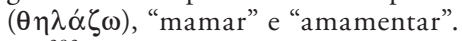

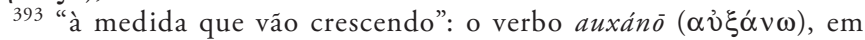
sentido intransitivo, não é do bom uso ático, em que é transitivo: "fazer crescer", "engrandecer"; o port. aumentar poderia servir, pois pode ter os dois sentidos. De toda a maneira, a ideia não é clara... 
LUCIANO - No entanto, se desconhecermos estes erros, também não reconheceremos os nossos próprios, já que te escapou este dito solecista. Nunca mais digas que és capaz de assinalar quem comete solecismos, e que tu próprio não cometes solecismos.

5. Isto é o que eu te digo. Mas Sócrates de Mopso ${ }^{394}$, com quem me relacionei no Egipto, dizia estas mesmas coisas com delicadeza, sem criticar os que cometiam erros.

Por exemplo, a um que lhe perguntara a que hora ${ }^{395}$ é que ele sairia, respondeu: "Quem poderia dizer-te que eu sairia hoje?" E como um outro dissesse ${ }^{396}$ : "Tenho uma boa herança paterna"397, ele perguntou: "Como dizes? O teu pai já morreu?" E como ainda um outro dissesse: "Ele é meu patricio"398, [Sócrates de Mopso] disse: "Não sabia que tu és estrangeiro". Como outro dissesse: "Fulano é de bêbeda"399, perguntou: "De mãe [bêbeda]... ou quê?". <Como outro dissesse ${ }^{400}>{ }^{* * *}$... leôes...

${ }^{394}$ Mopso, cidade da Cilícia, geralmente denominada Mopsou hestía

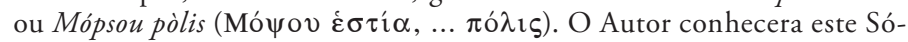
crates no Egipto. Poderia tratar-se um Sócrates grammático" (citado no Etumologicum Magnum), pelo que o ed. da "Loeb" sugere que Luciano fora seu discípulo. A obra seria, pois, dos primeiros anos de Luciano como escritor, mas também poferíamos datá-la dos últimos anos deste escritor, quando desempenhava altas funçóes no Egipto (185-190 d.C.?).

395 "a que hora", pénika ( $\pi \eta v i ́ \kappa \alpha)$ suscita uma resposta precisa sobre $a$ hora, mas a intenção é dizer quando?, caso em que o correcto seria usar o adv. mais geral póte ( $\pi$ ó $\tau \varepsilon)$. Este sentido de pēníka $(\pi \eta v i ́ \kappa \alpha)$ deveria ser cada vez mais usual, apesar das críticas dos puristas.

${ }^{396}$ E como um outro dissesse: “...”, ele disse: “...”: processo desagradavelmente repetitivo...

${ }^{397} \mathrm{O}$ que o outro queria dizer era "tenho em grande conta as coisas /

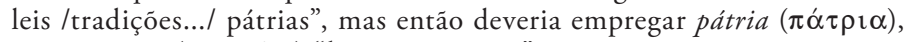
e não patrô $a(\pi \alpha \tau \rho \hat{\omega} \alpha)$ "herança paterna", o que pressupóes que o pai já havia morrido, como se diz logo a seguir.

398 "patrício", gr. (süm)patriốtēs, ( $(\cup \mu) \pi \alpha \tau \rho \imath \omega ́ \tau \eta \varsigma$, significa "meu patrício (de outro país ou cidade)", e só se dizia referido a estrangeiros; o que o outro queria dizer era "concidadão (desta cidade)", em gr. (sum)

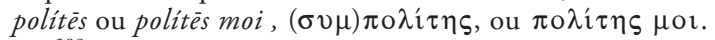

399 O que a pessoa pretendia dizer é que "Fulano é um bêbedo", gr.,

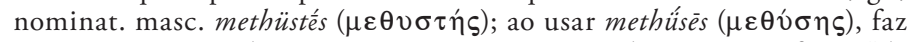
com que Sócrates de Mopso interprete como sendo um genit. fem., "de (mulher) bêbeda" (v, dics.: $\mu \varepsilon \theta \dot{\sigma} \sigma \varsigma, \mu \varepsilon \dot{\theta} \theta \sigma o \varsigma)$.

${ }^{400}$ Há aqui uma lacuna, que os editores preenchem desta maneira, mas em que o erro está irremediavelmente perdido. As soluçōes sugeridas são todas muito arriscadas. 
Sócrates replicou: "Então agora duplicas os leöes?**". E como outro dissesse: "Ele tem à vista um lêmma $(\lambda \hat{\eta} \mu \mu \alpha)$ [com dois $\left.-\mu \mu-{ }^{401}\right]$ "um ganho", Sócrates disse: "Então ele ganhará, uma vez que tem à vista um ganho". Como um outro dissesse: "Ai vem $o$ jovem amaricado ${ }^{402}$ meu amigo", ele comentou: "Entáo agora ofendes um teu amigo?" E a um que dissera: "Aterrorizo ${ }^{403}$ o homem e fujo", respondeu: "... E quando temeres alguém... persegui-lo-ás...”. E como outro dissesse: “o mais máximo ${ }^{404}$ dos meus amigos", replicou: "Tem graça o facto de pores algo acima do máximo". E como um certo fulano dissesse: "Exormô $(\dot{\varepsilon} \xi o \rho \mu \hat{\omega})$ [intr. "saio", "parto", "fujo" / trans. "ponho em debandada", "afugento"], ele perguntou: "E quem é esse que tu exormâs ( $\hat{i}_{i} \xi o \rho \mu \hat{\alpha} \varsigma$ ) [“afugentas"]?405 E como alguém dissesse: "ex epipolês" ( $\dot{\varepsilon} \xi \dot{\varepsilon} \pi \imath \pi \mathrm{o} \lambda \hat{\eta} \varsigma$ ) ["de dentro de uma superfície"], Sócrates comentou: "De dentro da superfície, como [se diz] de dentro do pote" ${ }^{\text {"406. }}$. E tendo alguém dito: "Pôs-me em ordem de batalha"407, ele comentou: "Também Xenofonte pôs as tropas em ordem de batalha." E como outro tivesse dito: periésthèn autòn

${ }^{401}$ E. H, Wermington (apud "Loeb", VIII, p. 18) elimina esta frase, que tem toda a aparência de ser um comentário inserido por algum copista. $\mathrm{O}$ que a pessoa pretendia dizer era que "ele tem força de vontade", gr. lêma $(\lambda \hat{\eta} \mu \alpha)$ [com um só $-\mu-]$.

${ }^{402}$ A palavra meîrax ( $\left.\mu \varepsilon \hat{\imath} \rho \alpha \xi\right)$, em ático, era do género feminino, e significava "uma jovem (a partir dos 14 anos)"; para o sexo masculino usava-se o "diminutivo" meirákion, meirakískos ( $\mu \varepsilon \imath \rho \alpha ́$ кıاov, $\mu \varepsilon \imath \rho \alpha \kappa i \sigma \kappa о \varsigma)$. Trata-se de um processo semelhante ao port. maricas, maricocas, de Maria.

${ }^{403}$ Em vez de "aterrorizo", dedittomai $(\delta \varepsilon \delta i ́ \tau \tau o \mu \alpha \imath)$, deveria dizer

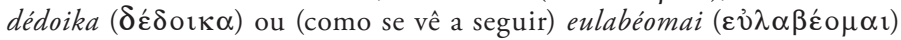
"temo"... pois só assim se justifica a fuga...

404 "mais máximo" ou "o mais principal", korüphaiótatos (корv$\varphi \alpha$ tó $\tau \alpha \tau$ ऽ) seria um superlativo de algo já superlativo, vomo koruphéo

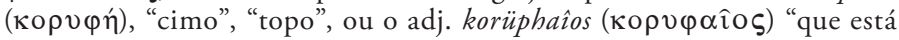
no topo". Em port. (!) ouve-se por vezes o solecismo mais maior...

${ }^{405}$ A pessoa usa indevidamente o verbo exormô $(\dot{\varepsilon} \xi o \rho \mu \hat{\omega})$ como intransitivo, mas Sócrates de Mopso, atendendo ao facto de o verbo, no ático, ser transitivo, pergunta-lhe pelo,,, complemento directo!

${ }^{406} \mathrm{O}$ que a pessoa queria dizer era o adv. superficialmente ou d̀ superfície, para o que bastava empregar o genit. adv. "epipolês" (દ̉ $\pi \mathrm{\imath} \pi \lambda \hat{\eta} \varsigma), \mathrm{A}$ preposição leva a intepretar a outra palavra como sendo o subst. "epipoléó"

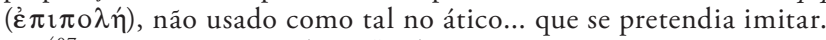

407 A pessoa queria dizer "ordenou-me", mas emprega um verbo de

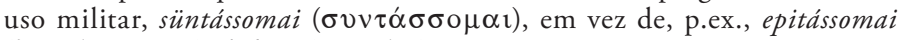

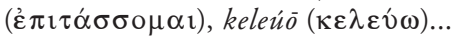




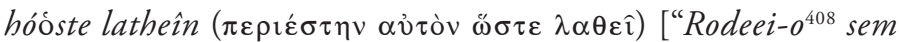
ele se aperceber]", ele disse: "É de admirar que tu, sendo um só, tivesses rodeado outro um só". E como outro tivesse dito: sü-

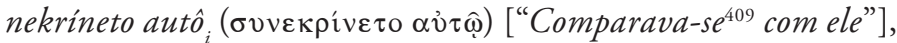
respondeu: "De toda a meneira, era diferente (dele)".

6. Sócrates [de Mopso] costumava brincar ligeiramente com os que cometiam solecismos do ponto de vista do ático ${ }^{410}$.

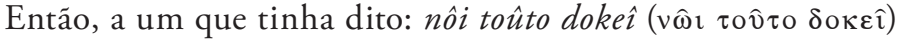
["nós dois ${ }^{411}$ isto parece"], respondeu: "Nesse caso, também dirás 'a nós dois erramos"”. Como outro narrasse, muito compenetrado, um dos episódios da sua pátria e tivesse dito: $H \bar{e}$ dè tô

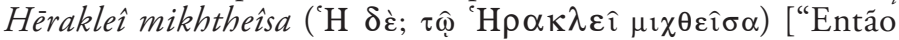
ela, tendo-se unido ${ }^{412}$ a Héracles"], Sócrates perguntou: "Então não foi Héracles quem se uniu a ela?”. E tendo um certo fu-

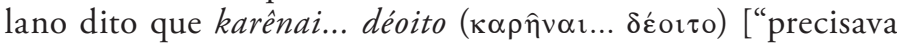
de ser tosquiado"], Sócrates disse: "Mas que crime cometeste tu, digno de pena desonrosa?" 413 . E como um outro usasse [o

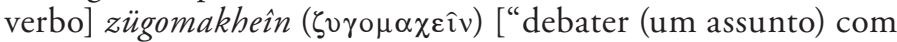
a esposa" 414 / "combater"], ele disse: "Vais combater contra o

${ }^{408} \mathrm{O}$ v. periístamai ( $\pi \varepsilon \rho \imath i ́ \sigma \tau \alpha \mu \alpha \imath$ ) tem dois sentidos: 1. "rodear / desviar-se de/ contornar/ alguém, a fim de a evitar (v. Hermotimo, \$86), "evitar alguém desviando-se do seu caminho", e 2. "cercar", "sitiar", sentido em que o sujeito de "cercar" náo pode ser singular, como se diz a esguir.

${ }^{409}$ O que o outro queria dizer era: "disputava com ele", com o v. diakrínomai ( $\delta \imath \alpha \kappa \rho i ́ v o \mu \alpha \imath)$, e não sügkrínomai ( $\sigma v \gamma \kappa \rho i ́ v o \mu \alpha \imath)$.

${ }^{410}$ Recorde-se que o critério de correcção assentava no dialecto ático clássico. Por vezes, a linguagem corrente sobrepunha-se inconscientemenete, e outras vezes, na ânsia de ser "aticista”, lá surgiam uns hiperaticismos...

411 A pessoa usa o nominat. dual, nôi (v⿳亠े⿵冂) em vez do dativo, nôin ( $v \hat{\omega} \imath v)$ "a nós dois"; por isso, Sócrates sugere o erro inverso, que consistiria em usar o dativo em vez do nominativo. A "versão" port. aproxima-se do erro cometido.

${ }^{412} \mathrm{O}$ v., pass., mígnümai ( $\mu$ í $\left.\gamma \nu v \mu \alpha \imath\right)$ "misturar-se com”... “unir-se a”, "ter relaçóes sexuais com” (dat.) tem sujeito masculino, mas aqui é usado com sujeito feminino. Em port., unir-se a (com sentido sexual) sugere um sujeito masculino, como ser activo. Aqui, o narrador fala como se esse papel pertencesse à mulher, o que sugere o comentário que se segue.

${ }^{413}$ Em vez de karênai ( $\left.\kappa \alpha \rho \hat{\eta} v \alpha \mathrm{l}\right)$, o homem deveria dizer keirasthai

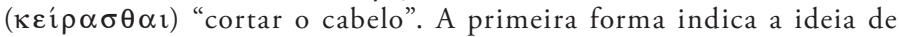
"tosquiar" (um animal) ou alguém a essa pena condenado.

414 "debater (um assunto) com a esposa" é o que homem pretende dizer, mas $S+o c r a t e s$ entende no sentido que considera correcto, ou seja, "combater". 
inimigo?". E tendo outro dito que "o seu filho doente ${ }^{415}$ estava a basanizesthai ( $\left.\beta \alpha \sigma \alpha v^{\prime} \zeta \varepsilon \sigma \theta \alpha \imath\right)$ ["ser posto à prova (com torturas)", "ser torturado" / "ser examinado" 416$]$, Sócrates disse: "Mas que é que o torturador pretendia (saber)?”. E tendo um outro dito que prokóptei ( $\pi \rho$ oкó $\pi \tau \varepsilon \imath$ ) ["estava a alongar-se" / "estava a progredir"] nos estudos, ele comentou: "Platão chama a isso

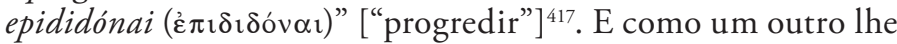
perguntasse: "Fulano vais discursar?418”, Sócrates respondeu: "Como é isso? Ao perguntares-me, a mim, se eu vou discursar, dizes fulano?”.

7. Tendo um fulano, com pretensões aticistas, dito tethnéóxei

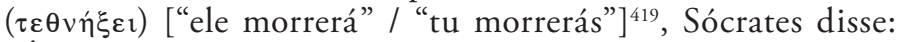
"É melhor, neste caso, não aticizares de modo agoirento". E

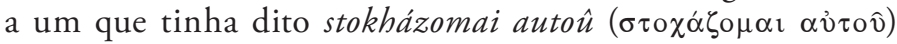

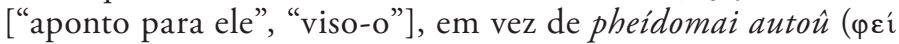
$\delta о \mu \alpha \imath \alpha$ v $\tau$ ov) ["poupo-o", "trato-o com cuidado"], respondeu: "Será que erraste o alvo?". E como um tivesse dito aphistân $(\dot{\alpha} \varphi 1 \sigma \tau \hat{\alpha} \nu)$ ["afastar", "separar"], e outro dissesse aphistánein

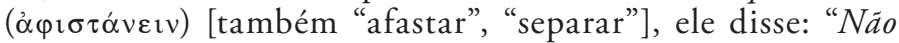

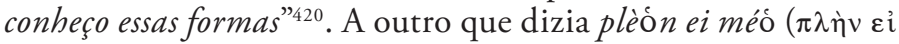
$\mu \eta \dot{)}$ [“excepto... senão"], disse: "Presenteias-me com uma dupla

415 "doente": esta indicação sugere que o sentido pretendido era "ser examinado (pelo médico)", e não "ser torturado".

${ }^{416}$ Era este o sentido pretendido, pelo que deveria ter usado (pass.) exetázesthai ( $\left.\xi_{\xi}^{\varepsilon} \tau \alpha \dot{\alpha} \zeta \varepsilon \sigma \theta \alpha \mathrm{l}\right)$, e não basanizesthai $(\beta \alpha \sigma \alpha v i \zeta \varepsilon \sigma \theta \alpha \mathrm{l})$, que significa um processo comum de obter uma confissão...

${ }^{417}$ Trata-se de uma precisão de linguagem, mas o sentido aqui criticado ("progredir") já se usava, mesmo no ático clássico, e também na koiné, (v. dics.).

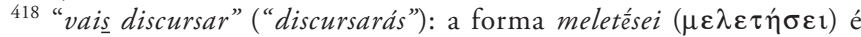
dúbia: $3^{a}$ p. sg. do fut. activo ("discursará”] e $2^{a}$ p. sg. fut. médio ("tu discursarás”). Parece que o homem não estava a cometer nenhum erro, mas Sócrates... de Mopso entende a forma como de $2^{\text {a }}$ pessoa média, uso, aliás, pouco frequente...

${ }^{419} \mathrm{O}$ fut. perf. pode ser (act.) tethnéxố $(\tau \varepsilon \theta v \eta \hat{\xi} \omega)$ ou (méd.) tethnéxomai $(\tau \varepsilon \theta \nu \eta \dot{\xi} \circ \mu \alpha \mathrm{l})$, mas, enquanto o homem pretendia significar a $3^{\wedge}$ pessoa, Sócrates interpreta como $2^{\text {a }}$ pessoa.

420 Aqui interessa, não o sentido, mas a morfologia: o verbo genui-

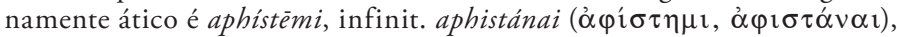
e não aphistáō, infinit. aphistân ( $\alpha \varphi \imath \tau \tau \alpha \dot{\alpha} \omega, \dot{\alpha} \varphi \imath \sigma \tau \hat{\alpha} \nu)$, nem aphistánō,

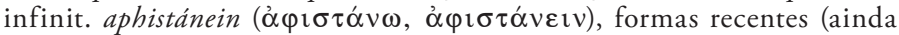
que a primeira ocorra em Xenofonte (Banquete, 2, 20), no optat. aphistố èn

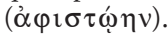


(negação)"’21. E como alguém tivesse dito khrâsthai $(\chi \rho \hat{\alpha} \sigma \theta \alpha \imath)$ ["usar", "usufruir"], disse: "Essa é uma forma pseudo-ática"'222.

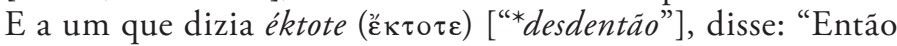

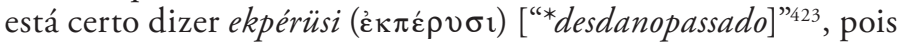
Platão diz es tóte (

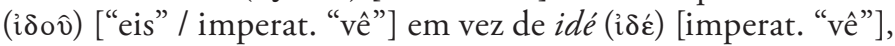
disse: "Significas uma coisa em vez de outra"425. E como alguém

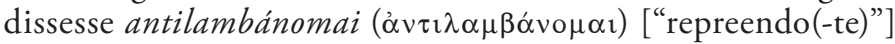

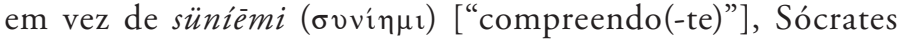
disse que se admirava com o facto de aquele, opondo-se ao seu interlocutor, afirmar que... nâo se lhe opunha ${ }^{426}$. E como alguém tivesse dito brádion ( $\beta \rho \alpha ́ \delta ı$ เov) ["mais devagar"], ele comentou: "Não é a mesma coisa que (dizer) tákhion ( $\tau$ áxiov) ["mais depressa"] 427 ". E tendo alguém usado [a forma] bareîn ( $\beta \alpha \rho \varepsilon \hat{\imath} v)$ ["estar sobrecarregado" / "sobrecarregar"], disse: "Não é a mesma coisa que barünein ( $\beta \alpha \rho$ v́veıv) ["sobrecarregar"], ao contrário do que tu pensas." ${ }^{\prime 28}$. E como alguém dissesse lélogkha $(\lambda \hat{\varepsilon} \lambda \mathrm{\gamma} \gamma \chi \alpha)$ ["obtive em sorte"] em vez de eílékha ( $\left.\varepsilon^{i} \lambda \eta \eta \chi \alpha\right)$ [“idem"], comentou: "É [forma usada] por poucos, e mesmo nesses é incorrecta”"29. E como muitos dissessem hiptasthai (i $\pi \tau \alpha \sigma \theta \alpha \imath$ ) ["voar"] em vez de pétesthai ( $\pi \varepsilon ́ \tau \varepsilon \sigma \theta \alpha \imath$ ) ["idem"], disse: "Bem sabemos que a deriva de ptêsis $\left(\pi \tau \hat{\eta} \sigma ı \varsigma^{\zeta}\right)$ ["voo"]". E como alguém tivesse dito peristerós ( $\pi \varepsilon \rho \iota \tau \varepsilon \rho o ́ \varsigma)$ ["pombo"],

${ }^{421}$ Note-se que a expressão "reforçada" ocorre no ático, ainda que esporadicamente.

${ }^{422}$ De facto, a forma ática é khrêssthai $(\chi \rho \hat{\eta} \sigma \theta \alpha \mathrm{\imath})$.

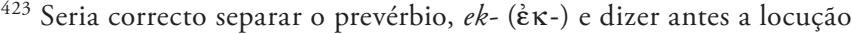

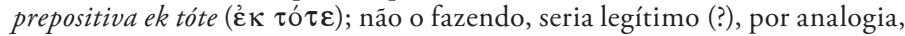

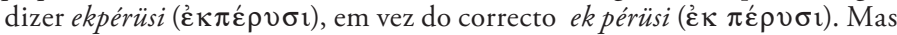
a forma considerada incorrecta já ia fazendo o seu caminho no falar corrente.

${ }^{424} \mathrm{O}$ exemplo de Platão parece autorizar o uso da preposiçáo (e prevérbio) $e k(\grave{\varepsilon} \kappa)$, por opsiçáo a es (’̉ $)$.

${ }^{425}$ A incorrecção (do ponto de vista da prosa ática) consiste em usar a interjeiçấo idoú (ỉoov́) ["eis"] como imperat. aor. médio de horáo (ópó $\omega)$...

${ }^{426}$ A ideia de "repreender (alguém)", ou "opor-se (a alguém") é contrária à de "compreender (alguém)", "concordar (com alguém)".

427 Trata-se, não do sentido de ambos os advérbios, mas do seu uso não-ático, que deveria ser, respectivamente, bradüteron ( $\beta \rho \alpha \delta$ v́ $\varepsilon \rho \circ v)$ e tâtton $(\theta \hat{\alpha} \tau \tau \mathrm{O} v)$.

${ }^{428} \mathrm{O}$ outro emprega bareîn ( $\left.\beta \alpha \rho \varepsilon \hat{\imath} v\right)$ com valor transitivo, mas Sócrates entende (mal: v. dics.) que o verbo é passivo-intransitivo, pelo que o outro deveris dizer, transitivamente, barünein ( $\beta \alpha \rho v ́ v \varepsilon \imath v)$.

${ }^{429}$ O perf. lélogkha $(\lambda \varepsilon \dot{\lambda} \mathrm{o} \gamma \chi \alpha)$ ocorre em Hom,. Hes., Píndaro, Eur., Heród. (v. dics.), pelo que Sócrates critica sobretudo o seu uso poético. 
forma alegadamente ática ${ }^{430}$, comentou: "Então também diremos pháttos ( $\varphi \alpha ́ \tau \tau o \varsigma)$ ["rolo"]" E como alguém tivesse dito que comera um... phakós ( $\varphi \propto \kappa o ́ \varsigma)^{431}$ ["vaso para óleo"], Sócrates disse: "Como é que alguém poderia comer um vaso para óleo?". Tais eram os comentários de Sócrates [de Mopso].

8. Mas, se achas bem, voltemos à discussão das [nossas] primeiras palavras ${ }^{432}$. Então, à medida que eu faço ocorrer todas essas "preciosidades" ${ }^{3} 33$, cabe-te a ti assinalá-las. Na verdade, julgo que tu, agora, já serás capaz [de fazê-lo], depois de ouvires uma tẫo grande série dessas palavras.

SOFISTA - Talvez nem agora seja capaz [de fazê-lo] à medida que tu falas. Em todo o caso, diz lá.

LUCIANO - Mas como é que dizes que não serás capaz? É que a porta já quase anéog ge (’̉vé conhecimento.

SOFISTA - Diz lá então.

LUCIANO — Mas eu já disse...

SOFISTA - Não disseste nada... pelo menos que eu desse por isso...

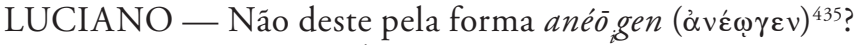

SOFISTA - Não, não dei.

LUCIANO - Mas que haveremos nós de fazer, se tu nem mesmo agora acompanharás as minhas palavras? E no entanto, em relaçáo ao que foi dito por ti no início ${ }^{436}$, eu julgava

${ }^{430}$ Embora ocorra, ainda que raramente, na comédia, o termo genérico é peristerá ( $\pi \varepsilon \rho \iota \sigma \tau \varepsilon \rho \alpha ́)$, "pombo" em geral, i.é, macho ou fêmea; "pomba”; do mesmo modo o termo genérico para "rolo" / "rola" é phátta ( $\varphi \alpha ́ \tau \tau \alpha)$. É como se em port. disséssemos andorinho, melra...

431 O homem pretendia dizer "uma lentilha", ou seja, "um preto de lentilhas” (v. dics.), phakê ( $\varphi \alpha \kappa \hat{\eta})$; no entanto, o masc. phakós ( $\varphi \alpha \kappa o ́ \varsigma)$ também existe no sentido de "lentilha crua"... mas esse sentido (talvez raro?) não convinha a Sócrates de mopso.

432 Refere-se ao método inicial, que consiste em dizer frases da própria cinversação, mas que contêm um solecismo, que o outro deve assinalar.

${ }^{433} \mathrm{O}$ texto dos manuscritos é confuso, pelo que os modernos editores tentam emendar de maneiras diversas. Entendo toùs beltístous ( $\tau$ ờ $\varsigma \beta \varepsilon \lambda \tau i ́$ $\sigma \tau 0 \cup \varsigma)$, lit. ${ }^{\text {te } ~ " e s s a s ~ b e l i ́ s s i m a s ~(p a l a v r a s) " ~ e m ~ s e n t i d o ~ i r o ́ n i c o . ~ S e r a ́ ? ~}$

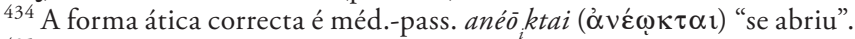

${ }^{435}$ Note que o uso do $-n(-v)$ final obedece à regra (não absoluta) de evitar o hiato.

${ }^{436}$ Mesmo no início do diálogo, o sofista afirma ser capaz de assinalar os solecismos... 
que estava a chamar os hippeîs (i $\pi \pi \varepsilon \hat{\imath} \varsigma)^{437}$ ["cavaleiros"] para a planície ${ }^{438}$... Notaste a forma hippeîs (i $\left.\pi \pi \varepsilon \hat{\imath} \varsigma\right)$ ? Mas tu pareces não ${ }^{439}$ dar atenção às palavras, nomeadamente àquelas que

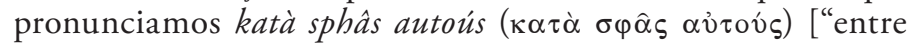
nós/eles próprios"] ${ }^{440}$.

SOFISTA - Eu dou atenção... tu é que as pronuncias de maneira pouco clara...

9. LUCIANO - O que não é mesmo claro é a expressão

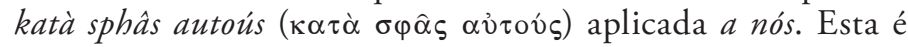
que é clara. Mas nenhum dos deuses seria capaz de pôr termo à tua ignorância... a náo ser Apolo. De facto, este manteúetai ( $\mu \alpha \nu \tau \varepsilon v ́ \varepsilon \tau \alpha \imath)$ ["consulta" / "dá consulta”, "emite oráculo", "profetiza”] para todos os que o interrogam. Tu, porém, náo te apercebeste do... manteuómenon ( $\mu \alpha v \tau \varepsilon v o ́ \mu \varepsilon v o v)$ ["da forma "consultar" $\left.{ }^{441}\right]$.

SOFISTA - Pelos deuses!, não percebi.

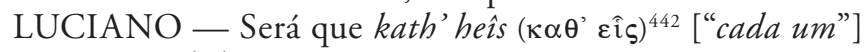
te escapa à medida que os percorres?

SOFISTA - Assim parece.

LUCIANO - Como é que te escapou [a expressão] kath' heîs ( $\left.\kappa \alpha \theta^{\prime} \varepsilon \hat{i} \varsigma\right)$ ?

SOFISTA - Também não percebo.

LUCIANO - Conheces alguém que pretenda para si próprio $^{443}$ um casamento?

${ }^{437} \mathrm{O}$ acusat. pl. ático é hippéas (i $\left.\pi \pi \varepsilon \dot{\varepsilon} \alpha \varsigma\right)$.

438 "chamar os cavaleiros para a planície": linguagem figurada, pois na planície é mais fácil a acção dos cavaleiros. Portanto, o sentido é: “julgando estar a facilitar-te a vida...”.

439 "pareces não" ou "não pareces", talvez outro solecismo...

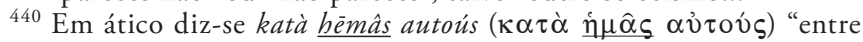
nós próprios". Parece tratar-se de um uso popular.

${ }^{441}$ Luciano quer dizer que é ilógico o sentido de "consultar" com o suj. Apolo; o sentido de "profetizar", "emitir um oráculo" deveria ser expresso, em ático, por khrân ( $\chi \rho \hat{\alpha} \nu)$ ou anaireîn ( $\alpha \nu \alpha \iota \rho \varepsilon \hat{\imath} v)$... mas o outro verbo também ocorre...

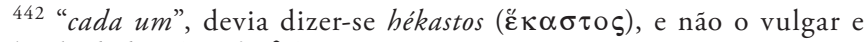
tardio kath' heîs ( $\left.\kappa \alpha \theta^{\prime} \varepsilon \hat{i} \varsigma\right)$.

443 "pretenda para si próprio": a forma média mnēsteuómenon ( $\mu \nu \eta \sigma \tau \varepsilon v$ ó $\mu \varepsilon v o v)$ já dispensa o uso do dat. hautô ${ }_{i}(\alpha \dot{v} \tau \hat{\omega}) \ldots$ mas a mesma sintaxe ocorre em Contra os Assalariados dos Grandes, \$23 (ad finem). Bastará esta contradição (e mais algumas...) para sustentar que esta obra não é de Luciano? Segundo outra interpretação, trata-se de pass. mnēsteúomai 
SOFISTA - Porque me perguntas isso?

LUCIANO - É que aquele que "pretende para si próprio um casamento" forçosamente comete um solecismo...

SOFISTA - Mas que é que tem que ver com o meu caso o facto de alguém cometer solecismo ao pretender ${ }^{444}$ [casar]?

LUCIANO - É que aquele que afirma saber ${ }^{445}$, afinal ignora. Pois seja assim. E então se alguém, passando por ti, te dissesse que apoleipoi ( $\alpha \pi \mathrm{o} \lambda \varepsilon \hat{\imath} \pi \mathrm{o})^{446}$ ["queria abandonar”] a mulher, será que tu lho permitirias?

SOFISTA - Como não havia de lho permitir, se ele fosse claramente o ofendido?

LUCIANO - E se ele cometesse claramente um solecismo, tu permitir-lhe-ias esse acto?

SOFISTA - Claro que não.

LUCIANO - Dizes bem. Realmente, não se deve deixar que um amigo cometa solecismo, mas, pelo contrário, há que ensiná-lo, de modo que náo lhe aconteça tal coisa... E então se agora uma pessoa, ao entrar [em casa], fizesse um ruído com a porta, e, ao sair, batesse [à porta] ${ }^{447}$, que diríamos que tu sentirias?

SOFISTA - Eu nada, mas apenas que aquele queria entrar ou sair.

LUCIANO - Nesse caso, não temos outro remédio senão considerarmos-te ignorante, por não distinguires quem $f a z$ barulho com a porta de quem bate à porta.

SOFISTA — Estás a ser muito insolente.

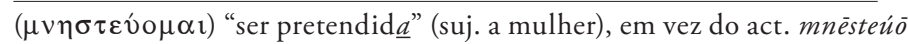
( $\mu \nu \eta \sigma \tau \varepsilon v ́ \omega)$ "pretender” (suj. o homem).

444 “ao pretender", ou (v. nota supra) “ao ser pretendid $a$ ”... É difícil decidir.

445 "aquele que afirma saber": o sofista do diálogo...

$446 \mathrm{O}$ v. apoleipoi ( $\alpha \pi \mathrm{o} \lambda \varepsilon \hat{\imath} \pi \mathrm{ol}$ ) só admite como sujeito "a esposa”, e significa "abandonar (a casa do marido)"; este, porém, divorcia-se, ou

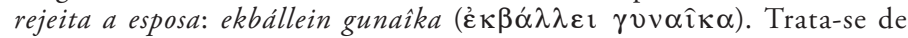
situaçóes do direito antigo, em que só o homem podia pôr legalmente termo ao casamento.

${ }^{447}$ Como as portas da rua abriam para fora, quem saía devia avisar quem passava na rua, para que este náo chocasse com a porta subitamente aberta;

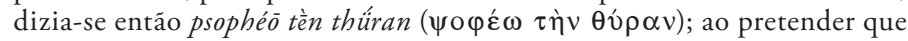
lhe abrissem a porta, a pessoa devia, naturalmente, bater à porta, kóptein tè̀n thüran (кó $\pi \tau \varepsilon \imath v \tau$ ̀̀v $\theta u ́ \rho \alpha v)$. Aqui, propositadamente, Luciano inverte os verbos... para ver se o outro assinala o solecismo. 
LUCIANO - Que é que estás a dizer? Insolente, eu? Sim, neste momento... sê-lo-eit ${ }^{448}$, ao conversar contigo... mas tu não reconheceste.

10. SOFISTA - Por Atena!, acaba lá com isso e fala de maneira que eu entenda.

LUCIANO - Mas como poderás entender?

SOFISTA - Se tu me assinalasses todos os solecismos que dizes sem eu dar poe eles e [assinalasses] em que consiste cada solecismo...

LUCIANO - De maneira nenhuma, meu caro, pois tornaríamos a conversa muito longa... Mas tu podes, nesta matéria, interrogar-me sucessivamente sobre cada ponto. Então agora, se te apraz, vejamos héter' átta (ع̈ $\tau \varepsilon \rho$ ' ó $\tau \tau \alpha$ ) [“alguns outros” (exemplos)], e desde já, este átta (ó $\tau \tau \alpha)$ parece, e muito correctamente, levar, não o espírito áspero, mas o espírito brando, dito assim ligado ao pronome hétera (๕̈ $\tau \varepsilon \rho \alpha)^{449}$. Se assim não fosse, seria ilógico... Mas a seguir vamos à [questáo da] insolência, em que tu dizes que eu $<$ te $>{ }^{450}$ ofendi, se não a ti em pessoa, pelo menos contra ti indirectamente ${ }^{451}$.

SOFISTA - Cá por mim, não sei que dizer.

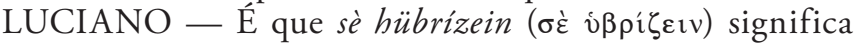
(ofender) o teu corpo, quer com golpes, quer com grilhöes, quer de qualquer outra maneira", ao passo que es sé (¿̇ $\sigma \delta \dot{\varepsilon}$ ) [usa-se] quando a ofensa é cometida contra algo que te pertence. De facto, aquele que ofende a tua mulher comete uma ofensa contra ti, tal como quem ofente um [teu] filho, um amigo e até um criado. É assim que deves entender, com excepção de "coisas", por exemplo, quando se diz es prâgma hübrizein (’̉ $\varsigma \rho \hat{\alpha} \gamma \mu \alpha$

448 "neste momento... sê-lo-ei" revela uma incoerência temporal: com

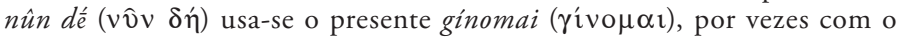
sentido de passado imediato: "sou" ou "acabo de ser".

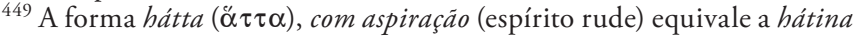
$(\alpha \varkappa \imath \downarrow \alpha)$ e significa "todas (as coisas) quantas", ao passo que sem aspiração (como é aqui o caso) significa "algumas coisas".

${ }^{450}$ Os mss. não têm se ( $\left.\sigma \varepsilon\right)$, que é acrescento de Gesner (apud "Loeb”, VIII, p. 36). Creio que a omissáo do pronome é propositada, para tornar mais vago o sentido, que vai ser precisado logo a seguir, com a distinção

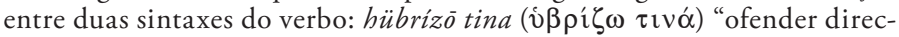
tamente uma pessoa” (física ou moralmente) e hübrizō eis tina (iß $\beta i \zeta \omega$ Ei $\zeta \imath \imath \alpha)$, "ofender uma pessoa com actos praticados sobre outra pessoa ou coisa pertencentes ao (deste modo) também ofendido." V. a seguir.

451 "contra ti indirectamente", ou seja, neste caso, contra as tuas ideias. 


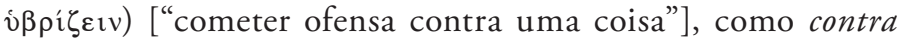
um provérbio, como diz Platão no Banquete ${ }^{452}$.

SOFISTA - Percebo a diferença.

LUCIANO - E será que também percebes que chamem solecismo ao facto de hüpallázein (i $\pi \alpha \lambda \lambda \alpha \dot{\alpha} \varepsilon \imath v)$ ["trocar (as palavras)"]?

SOFISTA - Desde já ficarei a saber.

LUCIANO - Significará isso enallázein ( $\dot{\varepsilon} v \alpha \lambda \lambda \alpha \dot{\zeta} \varepsilon \imath v)$ ["misturar (as palavras)"]?

SOFISTA - A mim parece-me a mesma coisa.

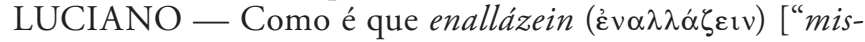
turar (as palavras)"] poderá ser a mesma coisa que hüpallázein (i $\pi \alpha \lambda \lambda \alpha \dot{\zeta} \varepsilon \imath v)$ ["trocar (as palavras)”]? Será que um pode ser usado em vez do outro, o correcto pelo incorrecto, a palavra que é por aquela que não é?

SOFISTA — Percebi que hüpallázein (i $\pi \alpha \lambda \lambda \alpha \dot{\alpha} \varepsilon \imath v)$ ["trocar"] consiste em dizer o sentido próprio em vez do sentido impróprio,

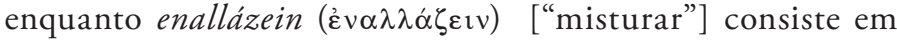
usar [indistintamente] ora o sentido próprio, ora o impróprio.

LUCIANO - Algumas destas espressôes têm um sentido

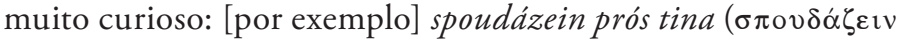
$\pi \rho o ́ \varsigma \tau \imath v \alpha$ ) ["mostrar zelo $a$ alguém"] revela um benefício pessoal para aquele que corteja, ao passo que (spoudázein) perí tina

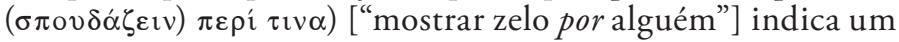
benefício para aquele por quem se mostra zelo. Talvez estas [duas] expressóes andem um tanto confundidas, mas também talvez seja rigorosamente observadas por outros... mas é preferível observar rigorosamente cada uma delas.

SOFISTA - Dizes muito bem.

11. LUCIANO - Sabes porventura que kathézesthai

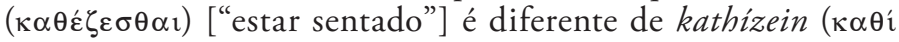

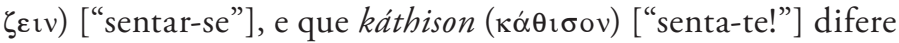
de káthēso (кó $\theta \eta \sigma o)$ [“fica sentado!"]?

$452 \$ 174$ b. Resumidamente, Sócrates, para ir a um banquete em casa de Agatão, embelezara-se todo, contra o seu hábito, e justifica-se com um provérbio, que ele propositada e ironicamente "ofende" ou "estraga". O provérbio diz: "A banquetes de agathôn ( $\alpha \gamma \alpha \theta \hat{\omega} v)$ ["de bons"], vão livremente os agathoí ( $\alpha \gamma \alpha \theta o i ́)$ ["os bons”], mas aqui o primeiro bons refere-se claramente a Agatão... e o segundo bons, referido por Sócrates a si mesmo, é irónico. 
SOFISTA - Não sei, mas no que toca à forma kathésthēti $(\kappa \alpha \theta \dot{\varepsilon} \sigma \theta \eta \tau \imath)$ [imperat. "está sentado!"] ouvia-te dizer que era bárbara ${ }^{453}$.

LUCIANO - E ouvias muito bem. Mas eu afirmo que

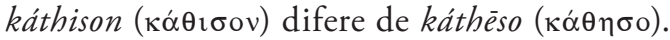

SOFISTA - E em que é que consiste a diferença?

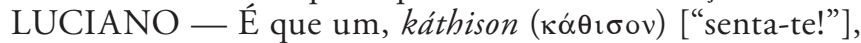
diz-se a uma pessoa que está de pé, enquanto o outro [káthèso

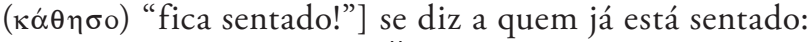

Fica sentado, estrangeiro, || que nós outro lugar encontraremos ${ }^{454}$,

equivalente a méne kathezómenos ( $\mu \varepsilon \dot{v \varepsilon \varepsilon ~ \kappa \alpha \theta \varepsilon \zeta o ́ \mu \varepsilon v o s) ~[" p e r m a-~}$ nece sentado"]. Fique dito, mais uma vez, que trocar estas duas formas é um erro. Porventura achas que é pequena a diferença

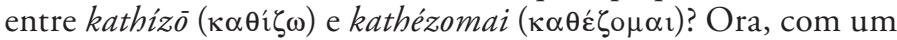
deles — refiro-me a kathizein ( $\left.\alpha \theta^{\prime} \zeta \xi \varepsilon v\right)$ ["sentar-se" / trans. "mandar sentar"] - fazemos que outro [se sente], enquanto kathézesthai $(\kappa \alpha \theta \varepsilon ́ \zeta \varepsilon \sigma \theta \alpha \imath)$ indica que o fazemos somente nós próprios ${ }^{455}$.

12. SOFISTA - Já explicaste cabalmente esta matéria, e de facto deves ensinar-me desse modo, [ou seja] previamente ${ }^{456}$. LUCIANO - Realmente, se eu falar de outra maneira, tu não entendes... Pois então... não sabes o que quer dizer um

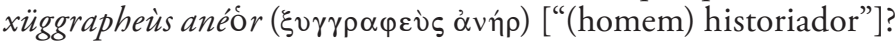
${ }^{457}$.

453 "bárbara" ou, pelo menos, recente e, de toda a maneira, não-ática

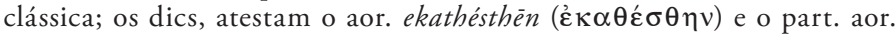
kathestheis ( $\kappa \alpha \theta \varepsilon \sigma \theta \varepsilon i \varsigma$ ), como formas tardias, e que, como tal, permitem aquele imperativo.

${ }^{454}$ Homero, $\mathrm{Od}$., XVI, 44. Telémaco entra no casebre do porqueiro, onde estava (sentado) o estrangeiro (afinal, Ulisses, seu pai), e diz-lhe que fique sentado. Note que nós... encontraremos é um plural majestático = "eu encontrarei".

455 Trata-se, com um pequeno desvio do que se discutia, da diferença entre transitivo "fazer sentar (alguém)" e intrans. "sentar-se".

${ }^{456} \mathrm{O}$ sofista quer dizer que o mestre, em vez de meter sorrateiramente erros de língua na conversa, deve apresentá-los desde logo, claramente, e seguidos da devida explicação: o aluno não está para se esforçar a detectar erros... O mestre que apresente a "papinha" já feita.

${ }^{457}$ Há nitidamente aqui uma lacuna, pois a resposta do sofista pressupóe uma explicação do mestre. Segundo M. D. Macleod ("Loeb” VIII, p. 43),

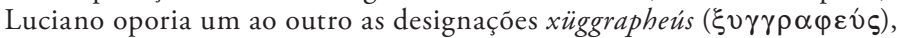
"historiador de factos contemporâneos do escritor, como Tucídides", 
SOFISTA - Agora já sei, depois de te ter ouvido explicar. LUCIANO - Tu provavelmente julgas que katadouloûn

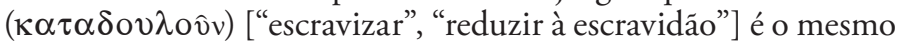

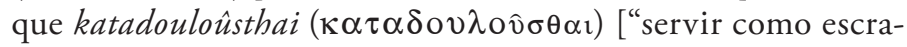
vo"], mas eu sei que a diferença entre ambos não é pequena.

SOFISTA - Qual é a diferença?

LUCIANO -É que um, katadouloûn ( $\kappa \alpha \tau \alpha \delta o v \lambda \mathrm{ov} v$ ), refere-se a outra pessoa, ao passo que o outro [katadouloûsthai $(\kappa \alpha \tau \alpha \delta \circ \nu \lambda \circ \hat{v} \sigma \theta \alpha \mathrm{l})]$ incide sobre a própria pessoa.

SOFISTA - Dizes bem.

LUCIANO - Ainda tens muitas mais coisas para aprender... a menos que julgues saber aquilo que não sabes.

SOFISTA - Não julgaria tal coisa!

LUCIANO - Então deixemos o resto para outra vez, e por agora interrompamos o diálogo.

e historiográphos (i $\sigma \tau 0 \rho \imath o \gamma \rho \alpha ́(\varphi) \varsigma)$, "contador de histórias passadas",

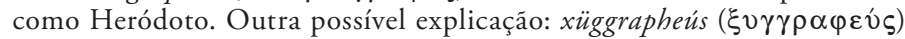
significaria "prosador" (incluindo "historiador"), por oposiçấo a poiètés

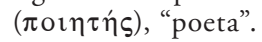


(Página deixada propositadamente em branco) 


\section{EPIGRAMAS}


(Página deixada propositadamente em branco) 


\section{INTRODUÇÁO}

$\mathrm{Na}$ Antologia Grega são atribuídos a Luciano (algumas vezes com pouca ou nenhu-ma segurança) 53 epigramas. A "Loeb" (Loeb Classical Library), nas obras completas de Luciano, apenas inclui, no fim (vol. VIII), o epigrama que aqui transcrevo e tra-duzo com o ${ }^{\circ} 1$. Apesar de se apresentar como sendo de Luciano, não podemos ga-rantir que o seja.

Quanto aos outros epigramas, sigo a ed. de W. R. Paton, "Loeb" (LCL), 5 vols. No-te se que, juntamente com a minha numeração, indico a localização dos epigramas na "Loeb" [LCL]. Além disso, incluí dois epigramas que alguns atribuem a Luciano, per-fazendo o número de 55.

À semelhança do que fazem alguns editores, cada epigrama vai antecedido de um pequeno título, entre parênteses rectos, que (com excepçáo, parece, do no 1 e mais um ou outro) não consta do manuscrito. 
(Página deixada propositadamente em branco) 


\section{EPIGRAMAS}

\section{1. [LCL, Lucian, VIII, p. 526; Fócio, Bibliotheca, 128, ad finem]}

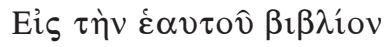

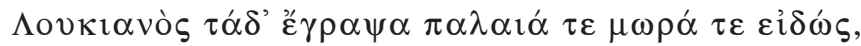

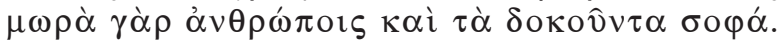

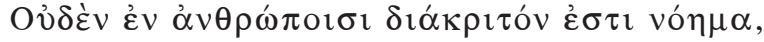

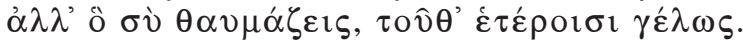

\section{PARA ESTE SEU LIVRO}

Eu, Luciano, autor sou desta história, || sabendo bem que são velhas sandices... de idiotices.

Mas mesmo o que para os homens é sensato \| não passa

$\mathrm{Na}$ mente dos humanos não existe || nenhum conceito claro e definido, risíveis.

mas aquelas histórias que tu gabas, || para outros são

NOTAS: 1. - O título PARA ESTE SEU LIVRO é uma epígrafe aplicável a determinada(s) obra(s), entre as muitas obras de ficção e fantasia que o Autor (Luciano?) produziu, como (se Luciano é mesmo o autor da epígrafe) Uma História Verídica, Lúcio ou O Burro, os famosos Diálogos (dos Mortos, dos Deuses, dos Deuses Marinhos...), etc. A qualquer delas se poderia aplicar a confissão deste epigrama: "sabendo bem que são velhas sandices". 2. — v. 1: gr. Loukianòj (com -a-breve), por necessidade métrica, ou Lou-kia-nòj (-yā-)? Ambos os processos são raros... mas a verdade é que o nome do autor, cujas três sílabas iniciais têm a estrutura crética ( ${ }^{-}$) , não cabe no hexâmetro, que só admite as sequências, ou "pés" dactílicos $\left(^{-}-\right.$) ou espondaicos $\left(^{--}\right)$. Virgílio (En., I, 2) resolveu o problema do tríbraco de $L \bar{a}-u \bar{\imath}-n \grave{\imath}-\breve{a}-$ que $\left(\left.\right|^{-} \cup \checkmark\right)$ por um processo idêntico: Lāa-uī-niă-quĕ (...-nyă-) ( $-^{-} \cup$ ). Diga-se que o processo não é elegante... mas... cada um tem o nome que tem. 3. - v. 1: os mss. deteriores têm œgraye ("escreveu"). 4. - v. 3: adopto a emenda de Guyet (apud "Loeb", 
VIII, p. 526), e não o adv. diakridòn. 5. — Dei à versão port. o aspecto métrico: vv. 1 e 3 (correspondentes ao hexâmetro): 10 \| 10; vv. 2 e 4 (correspondentes ao pentâmetro): 10 || 7.

\section{2. [LCL, vol. I, p. 306: Livro VI, no 17.}

\section{[OFERTAS DE MERETRIZES]}

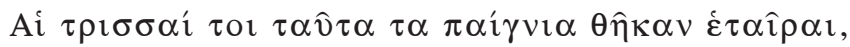

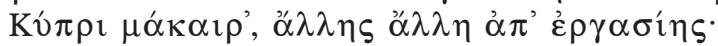

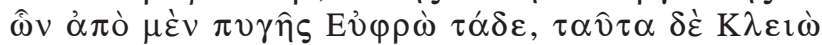

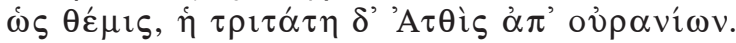

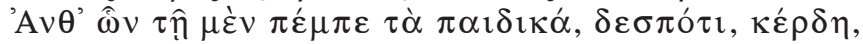
$\tau \hat{n} \delta \dot{\varepsilon} \tau \dot{\alpha} \theta \eta \lambda \varepsilon \dot{i} \eta s, \tau \hat{̣} \delta \dot{\varepsilon} \tau \grave{\alpha} \mu \eta \delta \varepsilon \tau \dot{\varepsilon} \rho \eta \varsigma$.

Três meretrizes dedicaram-te, ó bem-aventurada Cípris ${ }^{(458)}$, estas oferendas, fruto da especialidade de cada uma: Destas, Eufro ${ }^{(459)}$, [fruto] do ânus; Clio, da prática normal, e a terceira, Átis, da relação palatal.

Como paga disso, Senhora, dá a uma, como presentes, rapazinhos, a outra, mulheres, e à terceira... para nenhum dos $\operatorname{lados}^{(460)}$.

\section{3. [LCL, vol. I, p. 382: Livro VI, no 164. ${ }^{(461)}$}

\section{[UM NÁUFRAGO AGRADECIDO]}

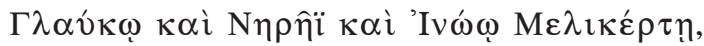

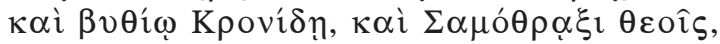

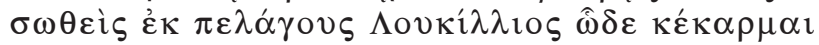

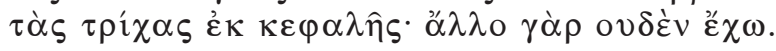

458 Cípris ou Cípride, ou seja, Afrodite, "a nascida das ondas», era especialmente venerada em Chipre.

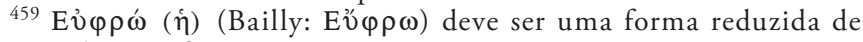

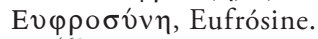

${ }^{460}$ Alude-se a três práticas pornográficas...; a terceira recompensa parece referir-se a "tipos neutros»...

${ }^{461}$ Segundo M. D. Macleod (v. Luciano, "Loeb”, VIII, . 525.), talvez de Lucílio (como é sugerido pelo texto), e não de Luciano. 
A Glauco ${ }^{(462)}$, a Nereu, a Melicertes, filho de Ino, ao Crónida das profundezas, e aos deuses samotrácios,

Eu, Lucílio, salvo do mar, agora mesmo rapei

os cabelos da minha cabeça ${ }^{(463)}$, pois não possuo mais nada.

4. [LCL, vol. II, p. 166: Livro VII, no 308.

\section{[EPITÁFIO DE UM MENINO]}

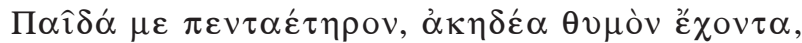

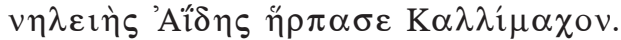

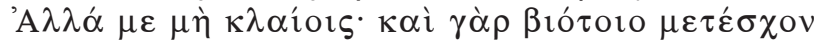

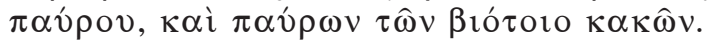

Menino de cinco anos, de alma livre de cuidados, o impiedoso Hades me arrebatou, a mim, Calímaco.

Mas não me chores, pois o que da vida gozei

pouco foi, mas também pouco dos seus males.

\section{5. [LCL, vol. III, p. 62: Livro IX, no 120.}

\section{[A INGRATIDÁO]}

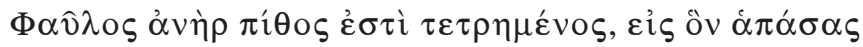

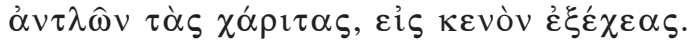

Um homem ruim é um tonel esburacado, para dentro do qual ao despejares todos os favores, verteste-os para o vazio.

462 Glauco, Nereu e Melicertes são deuses marinhos; o último era filho de Ino (ou Leucótea), tb. divindade marinha; Crónida = «filho de Crono"; este, esposo de Reia, é pai de Zeus (rei «celeste»), Hades (rei dos Infernos) e (é o caso) Posídon (rei dos mares); os deuses samotrácios são os Cabiros, originários da Ásia Menor e venerados especialmente na Samotrácia e em Lemnos, tinham um culto de mistérios e eram considerados protectores e salvadores de marinheiros.

${ }^{463}$ A rapagem completa dos cabelos era um ritual dos náufragos, como agradecimento às divindades salvadoras. 


\section{6. [LCL, vol. III, p. 200: Livro IX, no 367 .}

\section{[PRÓDIGO DO SEU E DO ALHEIO]}

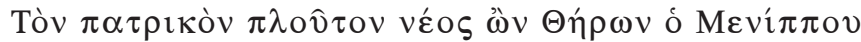

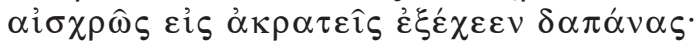

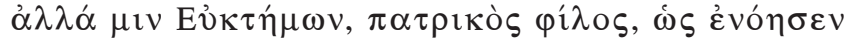

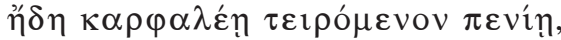

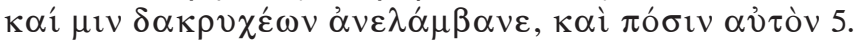

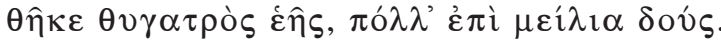

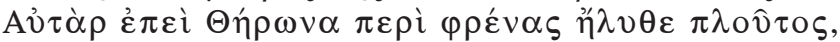

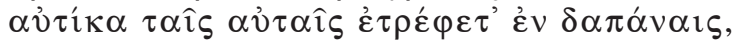

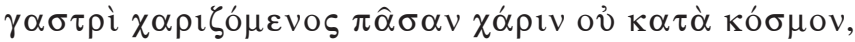

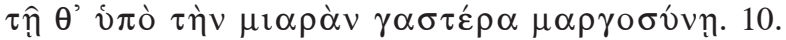

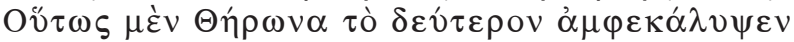

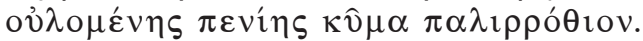

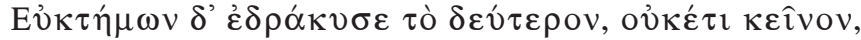

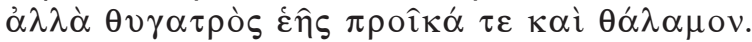

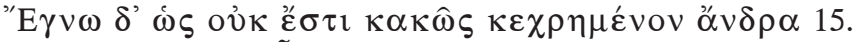

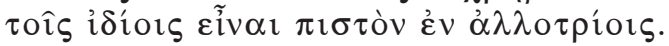

A fortuna paterna, Téron, filho de Menipo, sendo muito jovem, vergonhosamente esbanjou em pródigos gastos;

então Euctémon, amigo de seu pai, assim que se apercebeu de que ele se encontrava oprimido por uma penúria extrema,

muito choroso ${ }^{(464)}$, acolheu-o e deu-lhe por esposa 5. a sua própria filha, à qual deu um grande dote.

Logo, porém, que a riqueza entrou na alma de Téron, este recomeçou a entregar-se aos mesmos gastos, proporcionando ao estômago todos os luxos, sem qualquer regra, ao sabor da loucura ditada pelo maldito estômago. 10 .

E assim, pela segunda vez, caiu sobre Téron uma alterosa onda de funesta miséria.

Então Euctémon chorou pela segunda vez, já não por aquele, mas sim pelo dote da filha e pelo leito nupcial ${ }^{(465)}$.

Soube então que náo é possível que um homem que usou mal 15. dos próprios bens seja de confiança no caso de bens alheios.

${ }^{464}$ muito choroso: o suj. é Euctémon...

465 "leito nupcial", ou seja, "pelo casamento". 
7. [LCL, vol. IV, p. 18: Livro X, no 26.

\section{[A MODERAÇÃO: IN MEDIO VIRTUS]}

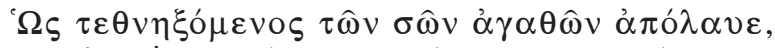

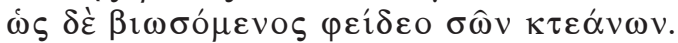

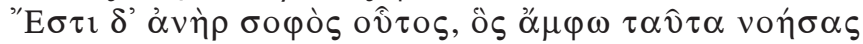

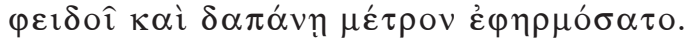

Goza dos teus bens como se estivesses para morrer, mas poupa a tua fortuna como se estivesses para viver.

É homem sábio aquele que, pensando em ambas as situações, aplica a moderação, quer na poupança, quer na despesa.

8. [LCL, vol. IV, p. 18: Livro X, no 27.

\section{[AOS DEUSES NADA ESCAPA]}

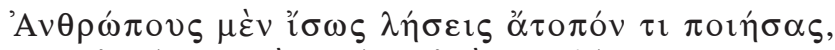

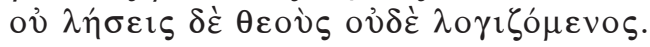

Talvez possas esconder dos homens um acto insensato, mas não o esconderás dos deuses, por muito que medites.

9. [LCL, vol. IV, p. 18: Livro X, no 28.

\section{[VIDA BREVE... VIDA LONGA]}

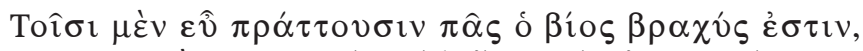

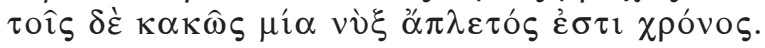

Para os bafejados da sorte, a vida toda é breve, mas para os infelizes uma única noite é um tempo sem fim. 
10. [LCL, vol. IV, p. 18: Livro X, no 29.

\section{[EROS, RÉU INOCENTE]}

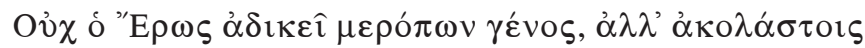

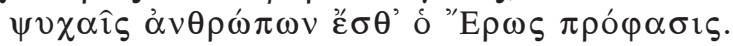

Não é Eros quem lesa o género dos mortais, mas, para as almas dissolutas dos homens, Eros é o pretexto.

11. [LCL, vol. IV, p. 20: Livro X, no 35 .

\section{[FORTUNA, DESVENTURA... E FALSOS AMIGOS]}

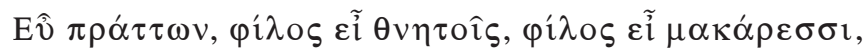

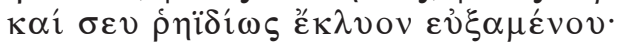

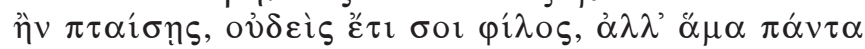

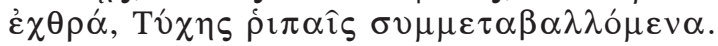

Se estás afortunado, és querido dos mortais, querido dos bem-aventurados,

e eles escutam com benevolência as tuas preces;

mas se tens um revés, ninguém é teu amigo, mas todas as coisas

ao mesmo tempo te são hostis, transformadas pelos golpes da Fortuna.

12. [LCL, vol. IV, pp. 20-22: Livro X, no 36 .

\section{[FALSOS AMIGOS]}

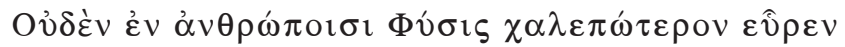

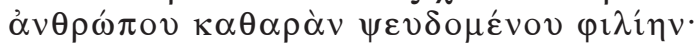

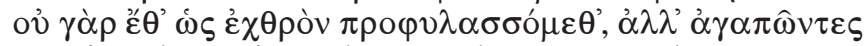

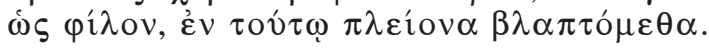

Nada entre os homens a Natureza produziu de mais pernicioso, do que um homem que finge uma amizade pura. 
De facto, não nos precavemos dele como inimigo, mas, amando-o

como amigo, por isso mesmo mais somos lesados.

13. [LCL, vol. IV, p. 22: Livro X, no 37.

\section{[PRUDÊNCIA NAS DECISÓES]}

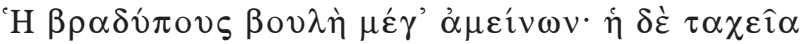

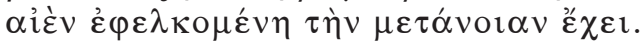

A decisão lenta é muito melhor; a rápida, porém, arrasta sempre consigo o arrependimento.

14. [LCL, vol. IV, p. 22: Livro X, no 41.

\section{[A VERDADEIRA RIQUEZA]}

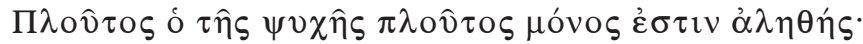

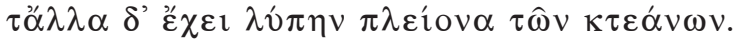

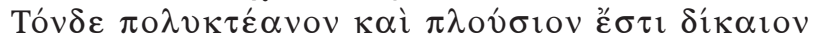

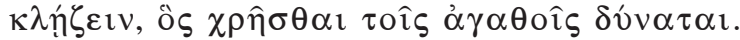

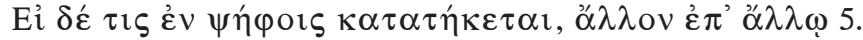

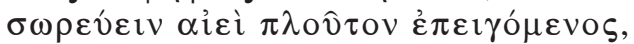

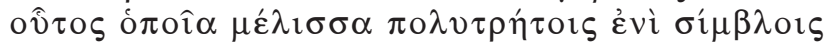

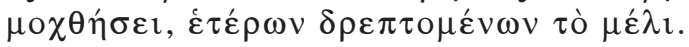

A riqueza da alma é a única verdadeira riqueza;

as restantes acarretam uma aflição superior aos bens.

Há que justamente considerar abastado e rico todo aquele que é capaz de usar dos seus bens.

Mas se um homem se consome nos cálculos [dos seus bens], 5 . apressando-se a acumular uma riqueza sobre outra riqueza,

esse afadiga-se tal qual uma abelha nos esburacados alvéolos, enquanto são outros que recolhem o mel. 
15. [LCL, vol. IV, p. 24: Livro X, no 42.

\section{[GUARDAR SEGREDO]}

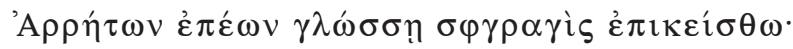

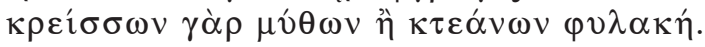

Imponha-se uma mordaça na língua [reveladora] dos indizíveis [mistérios $\left.{ }^{(466)}\right]$ : de fortuna.

sim, é melhor a guarda de palavras, do que a de bens

16. [LCL, vol. IV, p. 198: Livro XI, no 274.

\section{[TAGARELA COMPULSIVO]}

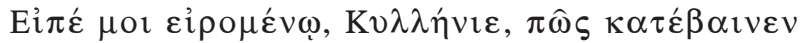

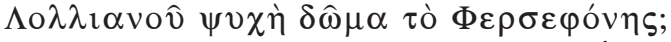

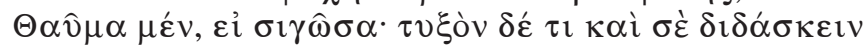

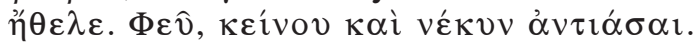

Diz-me cá, a mim que te pergunto, ó Cilénio ${ }^{(467)}$, como era, ao descer,

a alma de Loliano a caminho da morada de Perséfone.

Seria de admirar que estivesse calada; provavelmente, quereria morto!

ensinar-te algo. Que coisa! Topar com esse tipo mesmo

466 Pode, de facto, tratar-se do segredo dos mistérios, mas também de segredos em geral.

${ }^{467}$ Cilénio, «natural do monte Cilene», no sul da Arcádia, onde nasceu Hermes; entre outras funçôes, era o deus psicopompo, "condutor das almas dos mortos". 


\section{7. [LCL, vol. IV, p. 262: Livro XI, $n^{\circ} 400$.}

\section{[SANTA GRAMÁTICA!]}

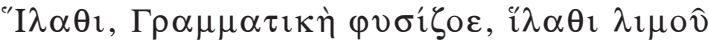

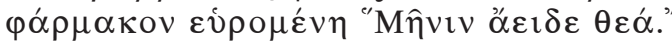

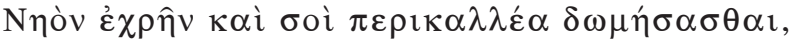

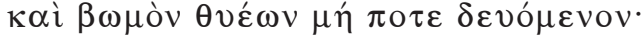

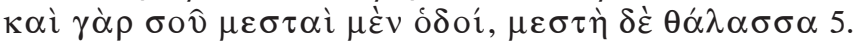

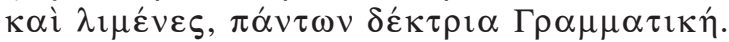

Sê-me favorável, Gramática vivificante, sê favorável, tu, que descobriste, como remédio contra a fome, "A ira canta, ó deusa... ${ }^{(468) ”}$

Devia erigir-se em tua honra um templo belíssimo, um altar em que nunca faltassem os incensos.

Sim, os caminhos estão repletos de ti, repleto o mar 5 . e os portos, ó Gramática, de todos acolhedora!

18. [LCL, vol. IV, p. 262: Livro XI, no 401.

\section{[GRAMÁTICOS E... MÉDICOS]}

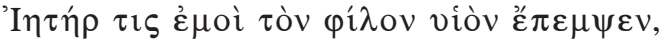

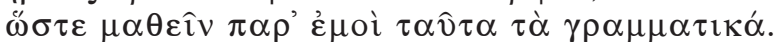

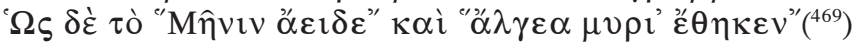

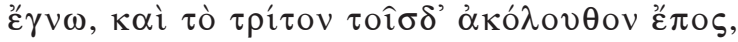

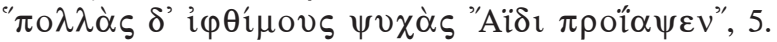

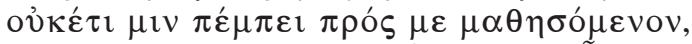

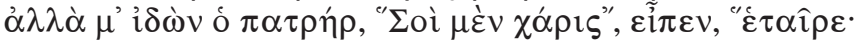

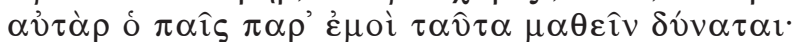

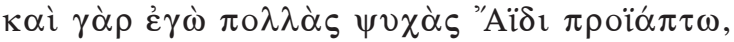

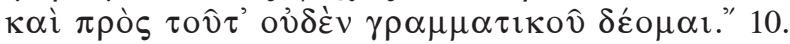

Certo médico enviou-me o seu querido filho, para aprender comigo estas primeiras letras.

468 Início da Ilíada.

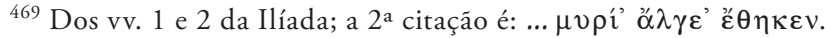


Mas logo que este leu o "Canta a ira" e "inúmeras dores causou",

e o terceiro verso, que se segue a estes,

"e muitas almas valorosas no Hades lançou", 5.

deixou de mo enviar para que aprendesse.

Então o pai, ao ver-me, disse: "Agradeço-te, meu amigo,

mas o rapaz pode aprender essas coisas comigo:

na verdade, também eu lanço muitas almas no Hades,

e para isso não preciso mesmo nada do gramático. ${ }^{(470) "}$

19. [LCL, vol. IV, pp. 262-264: Livro XI, no 402.

\section{[MALEFÍCIOS DA GULA REQUINTADA]}

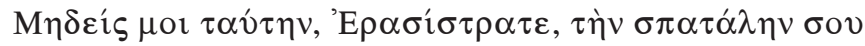
$\pi \mathrm{o} \eta \dot{\sigma \varepsilon \varepsilon} \theta \varepsilon \hat{\omega} v, \hat{i} \sigma \grave{v} \kappa \alpha \tau \alpha \sigma \pi \alpha \tau \alpha \lambda \hat{\alpha} \varsigma$,

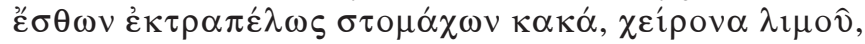

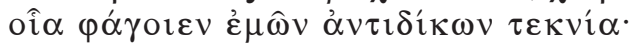

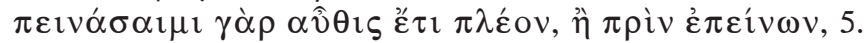

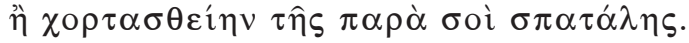

Que nenhum dos deuses, ó Erasístrato, me conceda

essa tua luxuosa mesa, em que fartamente vives,

devorando monstruosamente coisas danosas para os estômagos, piores que a fome,

que oxalá as comessem os filhos dos meus inimigos:

sim, antes passar fome, mais ainda do que outrora,

do que atafulhar-me, em tua casa, desses requintados pratos.

20. [LCL, vol. IV, p. 264: Livro XI, no 403.

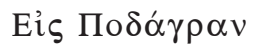

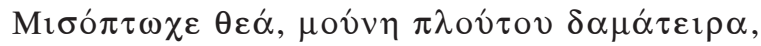

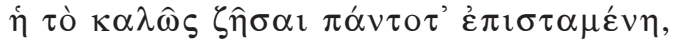

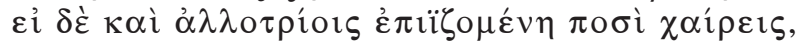

${ }^{470}$ Gramático era o professor das primeiras letras, do ensino elementar; a iniciação à leitura era feita, normalmente, com base na Ilíada. 


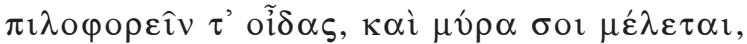

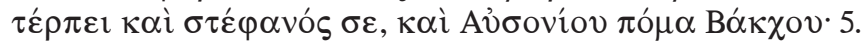

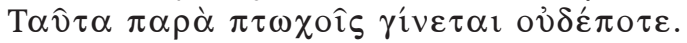

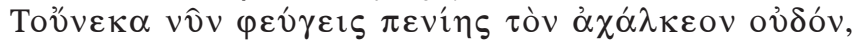

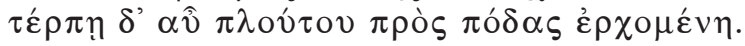

À Gota

Deusa que odeias os pobres ${ }^{(471)}$, a única dominadora da riqueza, tu que conheces a arte de sempre bem viver, que te comprazes em andar sobre os pés alheios ${ }^{(472)}$, tu que sabes usar barrete de feltro e te preocupas com perfumes, tu, a quem agrada uma coroa e a bebida do Baco Ausónio. 5. Tais bens nunca existem em casa dos pobres.

Por isso tu evitas a miserável porta da pobreza e pelo contrário te comprazes em chegar-te perto da riqueza.

\section{1. [LCL, vol. IV, p. 264: Livro XI, no 404.}

\section{[VANTAGENS DE TER UMA HÉRNIA!]}

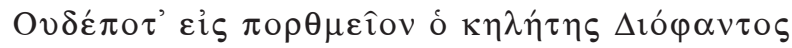

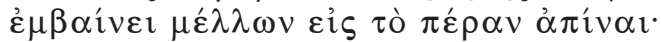

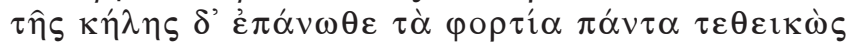

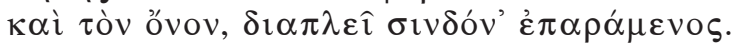

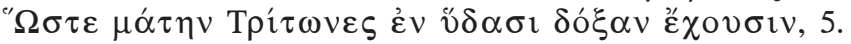

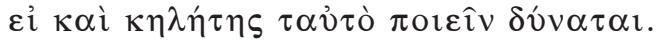

O hernioso Diofanto nunca sobe para uma barca, quando tem de se deslocar à outra margem:

em cima da hérnia coloca toda a carga, e mais o burro, e atravessa, erguendo a vela.

Assim, é em vão que os Tritões se orgulham de nadar sobre as ondas, pois também um hernioso é capaz de fazer a mesma coisa.

${ }^{471}$ A gota, ou podagra, era vista, com razáo, como uma doença de ricos, devida à gula e a alimentos prejudiciais à saúde, que provocam um grande aumento de ácido úrico e dores nas articulaçóes.

${ }^{472}$ Quer dizer: os doentes de gota são transportados às costas de outros (criados...). 
22. [LCL, vol. IV, pp. 264-266: Livro XI, no $405 .^{(473)}$

\section{[VANTAGENS E DESVANTAGENS DE UM NARIGÃO!]}

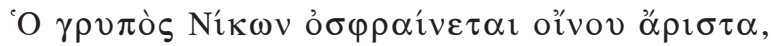

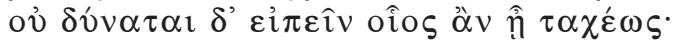

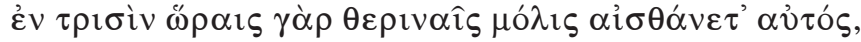

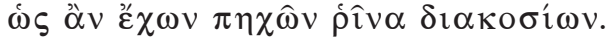

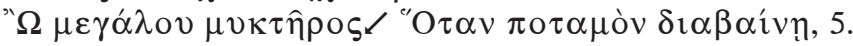

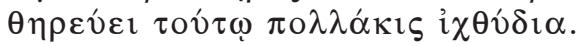

Nícon de nariz adunco ${ }^{(474)}$ cheira muitíssimo bem o vinho, mas não é capaz de dizer imediatamente de que tipo ele é, porque dificilmente o sente no período de três horas de verão $^{(475)}$,

uma vez que tem um nariz de duzentos côvados ${ }^{(476)}$.

Oh! que grande tromba! Sempre que atravessa um rio, 5. muitas vezes pesca peixinhos com o nariz.

23. [LCL, vol. IV, p. 266: Livro XI, no 408.

\section{[ILUSÓES DE TOILETTE]}

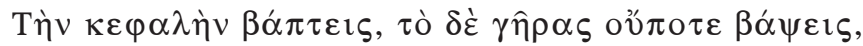

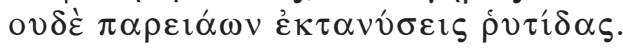

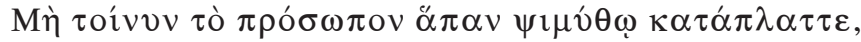

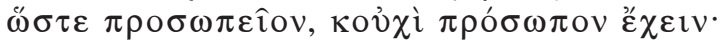

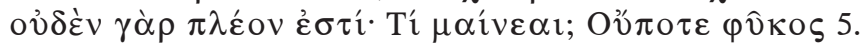

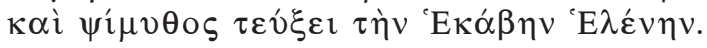

${ }^{473}$ Atribuído a Luciano na ed. "Teubner”, e "talvez Nicarco" por W. R. Paton.

${ }^{474} \mathrm{O}$ contexto sugere, para adunco, um conotação de grande tamanho.

475 três horas de verão... são mais longas que as de inverno...

${ }^{476} \mathrm{O}$ côvado equivalia a $0,444 \mathrm{~m}$... o que daria um nariz com c. 80 metros! 
Tinges os cabelos ${ }^{(477)}$, mas a velhice nunca poderás tingir, nem apagar as rugas do teu rosto.

Portanto, não esborrates todo o rosto com alvaiade, de tal maneira que ficas com uma máscara, não com um rosto.

Isso de nada te serve. Porquê essa loucura? Nunca uma tintura de alga 5 .

ou alvaide conseguirá fazer de Hécuba ${ }^{(478)}$ uma Helena.

\section{4. [LCL, vol. IV, p. 268: Livro XI, no 410.}

\section{[O CÍNICO E A GULA]}

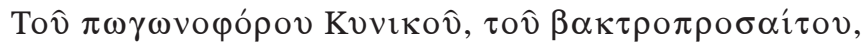

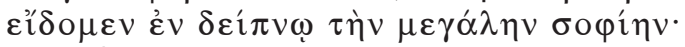

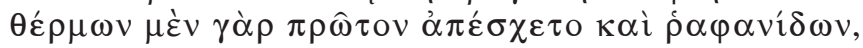

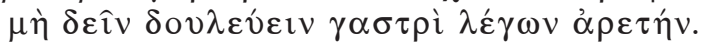

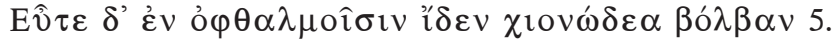

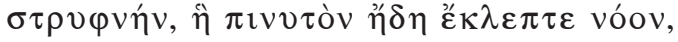

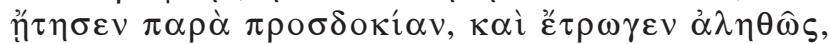

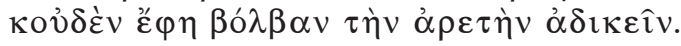

Daquele Cínico barbudo, pedinte munido de bengala, vimos a sua grande sabedoria durante um jantar:

De facto, começou por se abster de tremoços e de rábanos, dizendo que a virtude não deve ser escrava do estômago.

Mas logo que diante dos olhos viu uma vulva de porca alva de neve espírito,

e bem apimentada, que já lhe arrebatava o seu 'prudente'

pediu, contra toda a expectativa, que lha dessem, e devorava-a com gana,

afirmando que uma vulva de porca não ofendia a virtude.

${ }^{477} \mathrm{O}$ gr. diz «a cabeça»... mas percebe-se...

${ }^{478}$ Hécuba, a veneranda esposa de Príamo, rei de Tróia. 


\section{5. [LCL, vol. IV, p. 268: Livro XI, no 411. $\left(^{(779}\right)$}

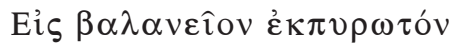

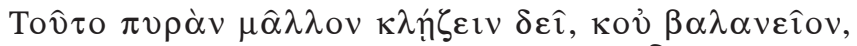

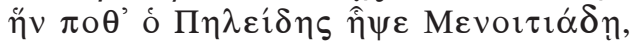

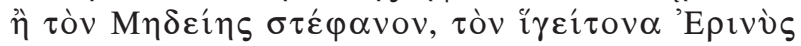

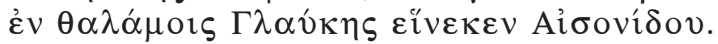

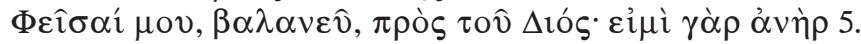

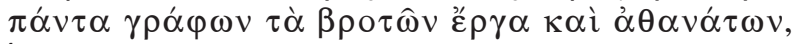

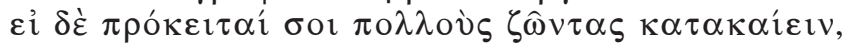

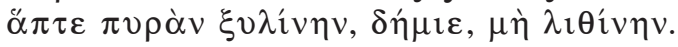

\section{[UM BALNEÁRIO SOBREAQUECIDO]}

Há que chamar a isto, não um balneário, mas uma pira Menécio, como a que o filho de Peleu ${ }^{(480)}$ acendeu para o filho de

ou a coroa de Medeia, †que a Erinia ateou $\dagger^{(481)}$

nos aposentos de Glauce, por causa do filho de Éson.

Perdoa-me, por Zeus!, chefe do balneário (pois eu sou um homem 5 .

que escrevo todos os actos dos mortais e dos imortais):

Se se trata de esturricar vivas muitas pessoas, ateia, funcionário público, uma pira de lenha, e não de pedra.

\section{6. [LCL, vol. IV, p. 274: Livro XI, no 427.}

\section{[VANTAGENS DO MAU HÁLITO!]}

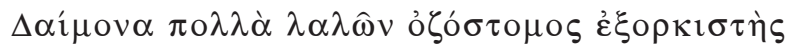

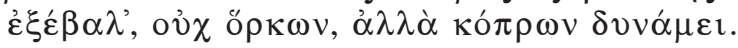

Um exorcista de mau hálito, pronunciando muitas fórmulas,

${ }^{479}$ W. R. Paton (Loeb) dá este epigrama como anónimo, mas, no índice, atribui-o a Luciano.

${ }^{480}$ O filho de Peleu: Aquiles; o filho de Menécio: Pátroclo.

481 Texto ininteligível, mas que se refere à vingança (a "Erínia") de Medeia, ao fazer incendiar os aposentos da sua rival, Glauce, nova esposa do «filho de Éson» (Jasão). 
expulsou um demónio, por força não das fórmulas, mas do cheiro nauseabundo.

27. [LCL, vol. IV, p. 274: Livro XI, no 428.

[O QUE O BERÇO DEU, A TUMBA O LEVA]

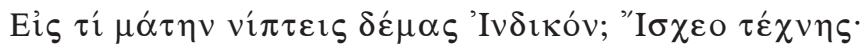

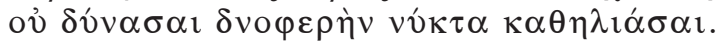

Porque lavas em vão a pele de um indiano? Deixa-te desse processo:

não podes iluminar com a luz do sol uma noite tenebrosa.

28. [LCL, vol. IV, p. 276: Livro XI, no 429.

[SÓBRIO NO MEIO DE BÊBEDOS]

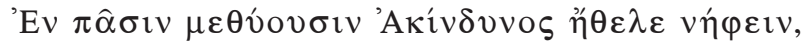

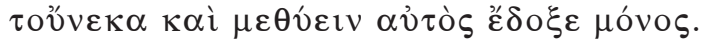

No meio de todos os bêbedos, Acíndino queria estar sóbrio, e por isso mesmo era ele que parecia ser o único bêbedo.

29. [LCL, vol. IV, p. 276: Livro XI, no 430.

[O HÁBIRO NÃO FAZ O MONGE]

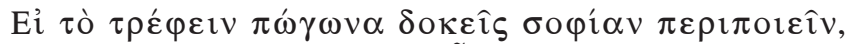

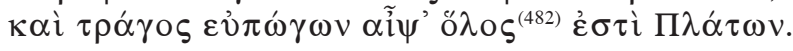

Se achas que deixar crescer a barba te dá sabedoria, então o bode de longas barbas é um completo Platão.

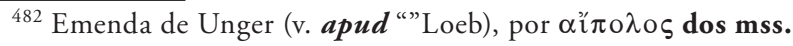


30. [LCL, vol. IV, p. 276: Livro XI, no 431.

\section{[COMER DEVAGAR... CORRER DEPRESSA]}

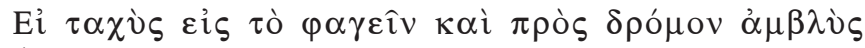
vं $\alpha \rho \chi \varepsilon i \varsigma$,

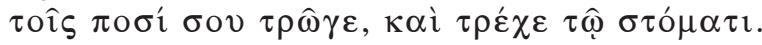

Se és rápido a comer e fraco na corrida, então come com os pés e corre com a boca.

31. [LCL, vol. IV, p. 276: Livro XI, no 432.

[PIOR A EMENDA...]

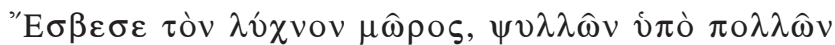

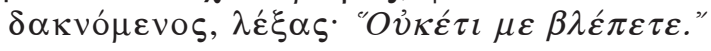

Um tipo cretino, mordido por muitas pulgas, apagou a candeia, dizendo: "Pois agora já não me vedes!"

32. [LCL, vol. IV, p. 276: Livro XI, no 433.

\section{[INSUFICIÊNCIAS DA PINTURA]}

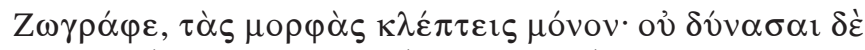

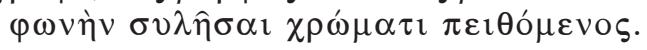

Pintor, tu captas somente as formas, mas não és capaz, só por meio da cor, de extrair a voz. 


\section{3. [LCL, vol. IV, p. 276: Livro XI, no 434.}

\section{[AS APARÊNCIAS... NÃO ILUDEM]}

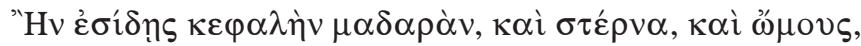

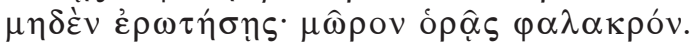

Se vires uma cabeça rapada, bem como o peito e os ombros [descobertos], careca $^{(483)}$.

não perguntes mais nada: estás vendo um imbecil

34. [LCL, vol. IV, p. 276: Livro XI, no 435.

\section{[NÃO É SOFISTA QUEM QUER]}

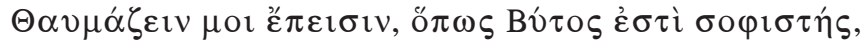

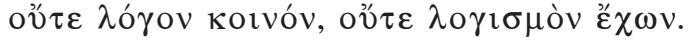

Causa-me grande espanto que Bito seja um sofista ${ }^{(484)}$, ele que não tem nem senso comum nem poder de raciocínio.

35. [LCL, vol. IV, p. 278: Livro XI, no 436.

[CORVOS BRANCOS, TARTARUGAS ALADAS = ORADOR CAPADÓCIO]

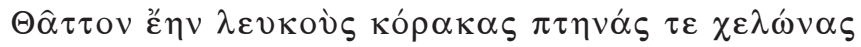

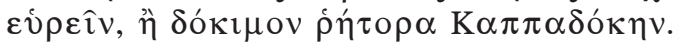

Mais depressa poderias corvos brancos e tartarugas com asas encontrar, do que um apreciado orador capadócio.

${ }^{483}$ Segundo W. R. Paton, deve referir-se aos filósofos cínicos, que assim se apresentavam.

${ }^{484} \mathrm{O}$ termo sofista tinha, no tempo de Luciano, o sentido de "sábio", «erudito», «intelectual». 
36. [LCL, vol. V, p. 250: Livro XVI, no 154.( ${ }^{(485)}$

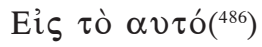

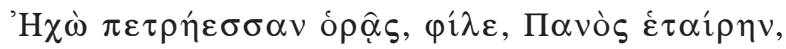

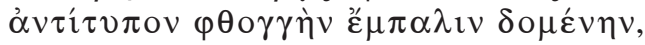

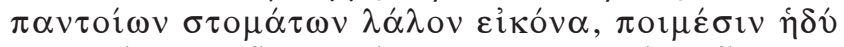

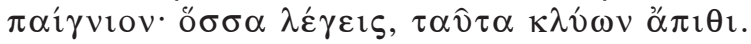

\section{[À MESMA (ESTÁTUA)]}

Estás vendo, amigo, Eco [a ninfa] dos rochedos, companheira de Pã,

a mim que canto de volta a voz que me atinge,

que sou a imagem falante de todo o tipo de vozes, agradável divertimento daqui.

dos pastores: Tudo aquilo que tu dizes, escuta-o e vai-te

37. [LCL, vol. V, p. 254: Livro XVI, no 163.

\section{[HÁ NUA E NUA]}

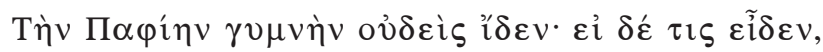

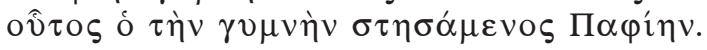

A deusa de Pafos ${ }^{(487)}$ ninguém a viu nua; mas se alguém [assim] a viu,

esse foi aquele que representou nua a deusa de Pafos.

$485 \mathrm{~Tb}$. atribuído a Árquias.

486 "À mesma», ou seja "À estátua da ninfa Eco» (do epigrama precedente, de um tal Sátiro).

${ }^{487}$ Afrodite, que tinha um templo em Pafos (Chipre). 
38. [LCL, vol. V, p. 254: Livro XVI, no 164.

\section{[A UMA CÍPRIS... HUMANA] [?]}

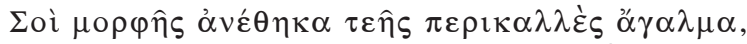

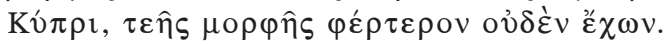

Eu te consagro uma belíssima estátua da tua formosura, ó Cíprisis ${ }^{(488)}$, pois não possuo nada melhor que a tua beleza.

\section{9. [LCL, vol. V, p. 300: Livro XVI, no 238.}

\section{[EU, PRIAPO, GUARDA DE MISÉRIA...]}

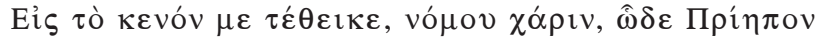

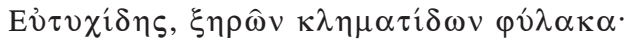

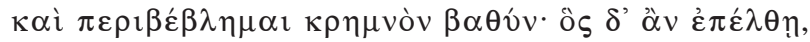

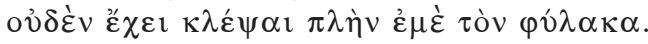

Aqui me colocou Eutíquides, neste descampado ${ }^{(489)}$, só por ser costume,

a mim Priapo, como guarda de ressequidas cepas.

Estou cercado de altos penhascos; e se alguém aqui chegar, não tem nada que roubar... a não ser a mim, o guarda.

${ }^{488}$ Cípris (ou Cípride) designa aqui, não a Afrodite Cíprica do epigrama precedente, mas uma personagem feminina com esse nome, a quem o autor e escultor dedica uma imagem.

${ }^{489}$ "neste descampado» ou "para nada», «em văo», «sem utilidade». 
40. [LCL, vol. I, p. 308: Livro VI, $\mathbf{n}^{\circ}$ 20. $\left({ }^{(400}\right)$

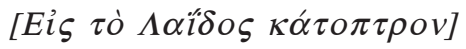

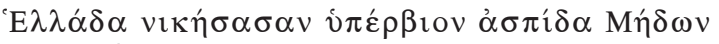

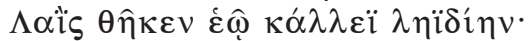

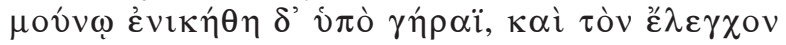

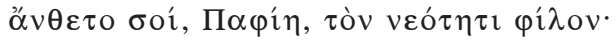

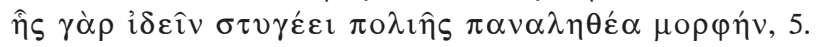

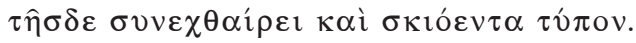

\section{[O ESPELHO DE LAIS]}

Lais $\left({ }^{491}\right)$, com a sua formosura, tornou cativa a Grécia, que já havia vencido o soberbo exército dos Medos, mas foi vencida somente pela velhice, pelo que te oferece, ó deusa de Pafos $\left({ }^{492}\right)$, este testemunho querido da sua juventude ${ }^{(493),}$

pois tem horror de ver o aspecto bem verdadeiro das suas câs, 5 . cuja imagem sombria lhe causa aversão.

\section{1. [LCL, vol. IV, p. 18: Livro $X, n^{\circ}$ 30.(494)}

\section{[QUEM DÁ DEPRESSA, DÁ DUAS VEZES]}

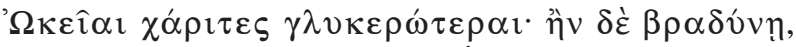

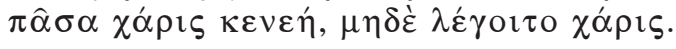

Os favores rápidos são mais agradáveis; mas todo o favor, se tarda, é vão, e nem se chamaria «favor».

${ }^{490}$ Atribuído a Luciano na ed. "Teubner", e a Juliano «Prefeito do Egipto», por W. R. Paton.

${ }^{491}$ Lais (ou Láide), famosa cortesã de Corinto, comhecida em toda a Grécia.

${ }^{492}$ Afrodite, que tinha um templo em Pafos (Chipre).

493 o "testemunho da sua juventude», ou seja, o espelho.

${ }^{494}$ Atribuído a Luciano na ed. "Teubner”, e "anónimo” por W. R. Paton. 
42. [LCL, vol. III, p. 38: Livro IX, n $^{\mathbf{0}}$ 74.(495)

\section{[A RODA DA FORTUNA]}

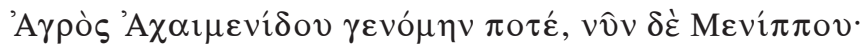

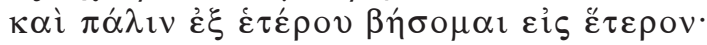

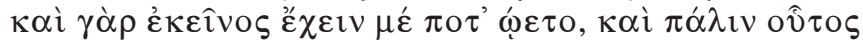

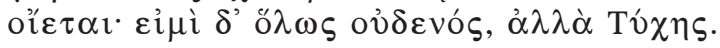

Outrora fui um campo de Aqueménides, agora sou de Menipo, e passarei de novo de um dono para outro.

$\mathrm{Na}$ verdade, aquele julgava então possuir-me, e este por sua vez assim também o julga. No fundo, porém, pertenço ao Acaso.

\section{3. [LCL, vol. IV, p. 62: Livro X, no 122. $\left({ }^{(99}\right)$}

\section{[O PODEROSO DESTINO]}

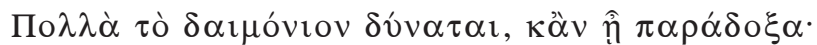

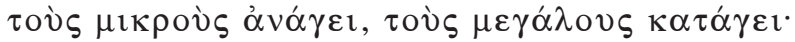

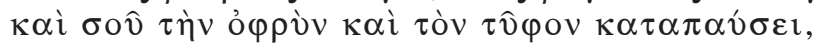

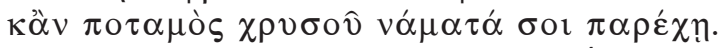

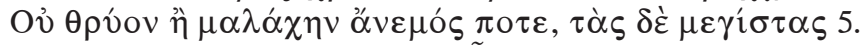

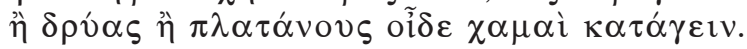

A divindade ${ }^{(497)}$ é capaz de muitas coisas, mesmo que improváveis:

aos pequenos, eleva-os, e aos grandes rebaixa-os;

também porá fim à tua sobranceria e à tua soberba, mesmo que um rio te traga torrentes de ouro.

Nem o junco nem a malva o vento é capaz de atirar por terra, 5 .

mas sim, por maiores que sejam, carvalhos ou plátanos.

${ }^{495}$ Atribuído a Luciano na ed. "Teubner”, e "anónimo” por W. R. Paton.

${ }^{496}$ Atribuído a Luciano na ed. "Teubner”, e a Lucílio por W. R. Paton.

${ }^{497}$ A divindade pode aqui significar, especificamente, a deusa Tú $\chi$, «Sorte», «Fortuna», «Destino». 
44. [LCL, vol. IV, p. 24: Livro $X, n^{\circ}$ 43. ${ }^{(498)}$

\section{[TEMPO PARA TRABALHAR, TEMPO PARA VIVER]}

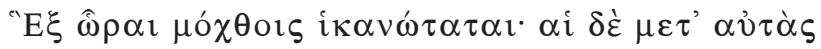

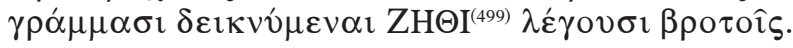

Seis horas ${ }^{(500)}$ bastam para os trabalhos; as que a estas se seguem

dizem aos mortais, mostrando-o por letras: ZHQI.

45. [LCL, vol. IV, p. 110: Livro XI, no 80. $\left(\left(^{501}\right)\right.$

\section{[O FIM DE UM PUGILISTA]}

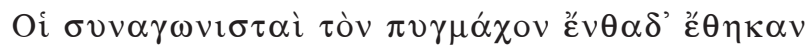

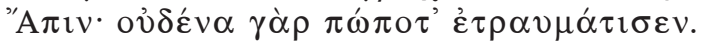

Os seus antagonistas colocaram ${ }^{(502)}$ aqui [a estátua d]o pugilista

Ápis: na verdade, nunca mais ferirá ninguém.

${ }^{498}$ Atribuído a Luciano na ed. “Teubner”, e “anónimo” por W. R. Paton.

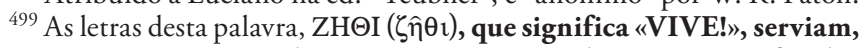
na numeraçáo, para os valores $7,8,9,10$; as seis horas acima referidas aludem, neste contexto, às primeiras seis letras usadas na numeração: $\mathrm{A}\left(\alpha^{\prime}\right) 1$; B $\left(\beta^{\prime}\right) 2$; $\mathrm{G}\left(\gamma^{\prime}\right)$ 3; D $\left(\delta^{\prime}\right) 4$; E $\left(\varepsilon^{\prime}\right)$ 5; $F\left(\varsigma^{\prime}\right)$ 6.; naturalmente, este passo é completamente intraduzível, já que as $7^{\mathrm{a}}, 8^{\mathrm{a}}, 9^{\mathrm{a}}$ e $10^{\mathrm{a}}$ letras do alfabeto português, GHIJ, náo dáo qualquer palavra, e muito menos uma que significasse "VIVE" ou ideia compatível.

${ }^{500}$ Trata-se aqui das horas romanas: hora prima (entre as 6 e as $7 \mathrm{da}$ manhã), secunda, tertia, quarta, quinta, sexta (entre as 11 e o meio-dia), que o A. remete para as seis primeiras letras do (mais antigo) alfabeto grego: v. nota supra.

${ }^{501}$ Atribuído a Luciano na ed. “Teubner”, e a Lucílio por W. R. Paton.

${ }^{502}$ Um sentido mais directo será: «depuseram (= «sepultaram») aqui o pugilista Átis», o que dispensa a interpretação da [estátua]. De toda a maneira, o contexto mostra que Átis já estava morto. 
46. [LCL, vol. IV, p. 112: Livro XI, no 81. ${ }^{(503)}$

\section{[FIM DE OUTRO PUGILISTA]}

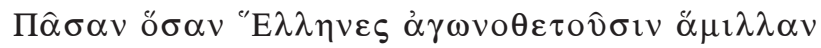

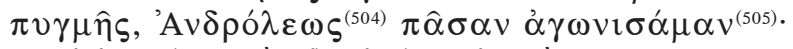

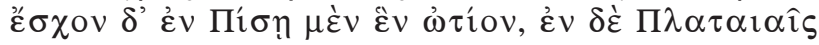

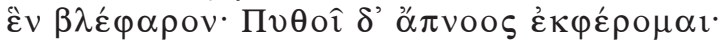

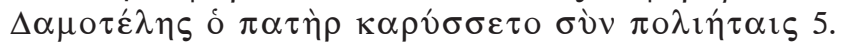

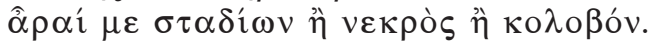

Todas as competições de pugilismo que os Gregos organizam, eu, Androlau, em todas combati:

em Pisa deixei uma orelha, em Plateias um olho ${ }^{(506)}$, e em Pito ${ }^{(507)}$ fui retirado sem respirar.

Então meu pai Damóteles teve ordem do arauto para que com [outros] cidadãos

me retirassem do estádio, ou morto ou estropiado.

47. [LCL, vol. IV, p. 184: Livro XI, no 239. $\left({ }^{508}\right)$

\section{[UMA MERETRIZ COM MAU HÁLITO]}

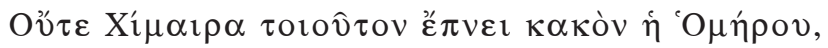

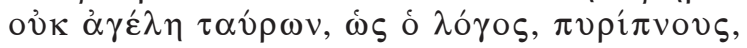

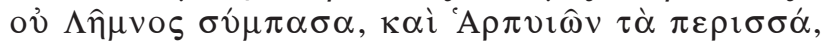

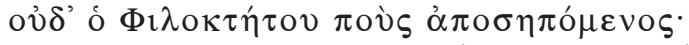

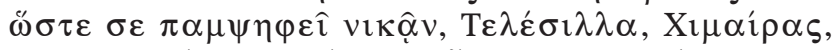

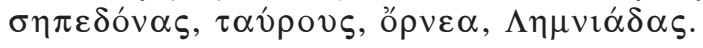

${ }^{503}$ Atribuído a Luciano na ed. "Teubner", e a Lucílio por W. R. Paton; em dialecto dórico.

${ }^{504}$ 'A $A \delta \rho o ́ \lambda \varepsilon \omega \varsigma$, nom. jón. (<-hoj, que sofre metátese de quantidade); a forma át. seria 'A $A \delta \rho o ́ \lambda \bar{a} o s$.

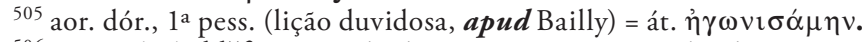

506 O vocábulo blšfaron "páloebra" tem aqui o sentido abrangente de «olho».

${ }^{507}$ Pito é outro nome de Delfos.

${ }^{508}$ Atribuído a Luciano na ed. "Teubner", e a Lucílio por W. R. Paton. 
Nem a Quimera de Homero exalava um cheiro tão nojento, nem a manada de touros, que, segundo a lenda, vomitavam fogo,

nem Lemnos inteira ${ }^{(509)}$, nem os excrementos das Harpias, nem o pé gangrenado de Filoctetes.

Assim, Telesila, tu, por consenso geral, vences quaisquer Quimeras $^{(510)}$,

gangrenas, touros, aves e mulheres de Lemnos.

48. [LCL, vol. IV, p. 184: Livro XI, no 240.( $\left.{ }^{511}\right)$

\section{[OUTRA MERETRIZ COM MAU HÁLITO]}

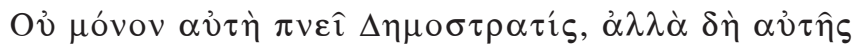

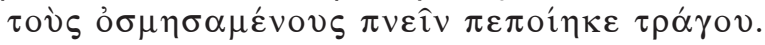

Não só ela própria, Demóstratis, exala cheiro a bode, mas até faz com que exalem esse cheiro aqueles que a cheiram.

49. [LCL, vol. IV, p. 132: Livro XI, no 129. ${ }^{(512)}$

\section{[ÍSTMIAS... PARÍSTMIAS; PÍTIAS... PARAPÍTIAS]}

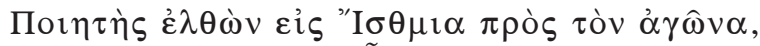

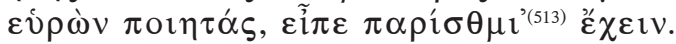

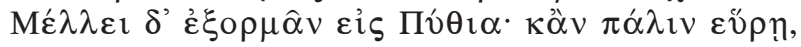

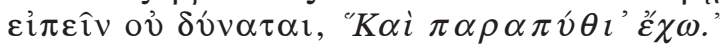

${ }^{509}$ As mulheres de Lemnos, que haviam assassinado os maridos, foram punidas por Afrodite, que fez com que elas exalassem um cheiro horrível.

${ }^{510} \mathrm{O}$ pl. significa «a Quimera propriamente dita e outros monstros semelhantes».

${ }^{511}$ Atribuído a Luciano na ed. "Teubner”, e a Lucílio por W. R. Paton.

512 Atribuído a Luciano na ed. "Teubner", e a [Iulius] Cerealis (poeta épico e pastoril, amigo de Marcial) por W. R. Paton.

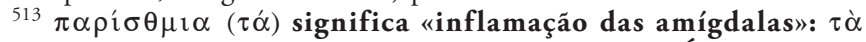
¡́ $\sigma \mu \uparrow \alpha$ "garganta», mas, com maiúscula, "os Jogos Ístmicos»; há aqui um jogo de palavras, com a invençáo do termo $\pi \alpha \rho \alpha \pi v ́ \theta \imath \alpha$, que não significa... nada. De toda a maneira, este epigrama é intraduzível... 
Um poeta, tendo-se deslocado ao Istmo por altura dos Jogos, ao encontrar outros poetas, disse que tinha... "parístmia”. [amigdalite]

Agora vai partir para os [Jogos] Píticos; então, se voltar a encontrar [os mesmos],

já não pode dizer: "Tenho... parapítia".

\section{0. [LCL, vol. IV, p. 72: Livro XI, ${ }^{\circ}$ 10.(514)}

\section{[JANTARES SEM POETAS]}

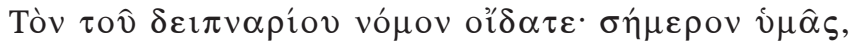

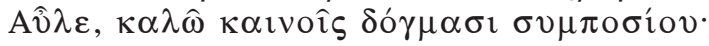

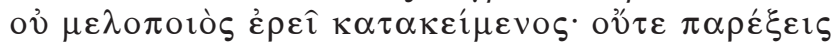

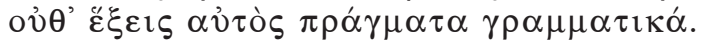

Conheces ${ }^{(515)}$ o regulamento dos meus pequenos jantares, mas hoje, Aulo, convido-te para novas regras do banquete:

Nenhum poeta lírico tomará parte nele nem declamará; não apresentarás

nem trarás contigo materiais literários.

\section{1. [LCL, vol. IV, p. 272: Livro XI, $n^{\circ}$ 420. (51) $^{51}$}

\section{[O CALADO É O MELHOR]}

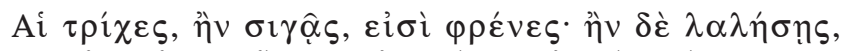

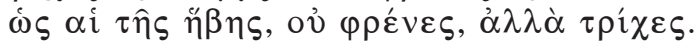

Os teus cabelos, se estiveres calado, são sensatos, mas se falares,

são como os da juventude, não sensatos, mas... cabelos.

514 Atribuído a Luciano na ed. “Teubner”, e a Lucílio por W. R. Paton.

515 O texto tem "conheceis», pl. majestático, como logo a seguir convido-vos.

${ }^{516}$ Atribuído a Luciano na ed. “Teubner”, e a «anónimo» por W. R. Paton. 


\section{2. [LCL, vol. IV, p. 172: Livro XI, no 212.(517)}

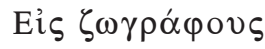

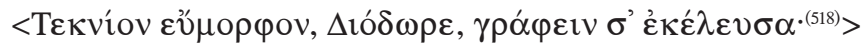

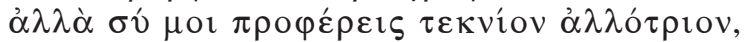

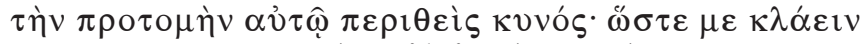

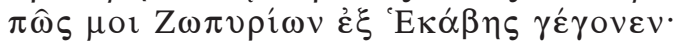

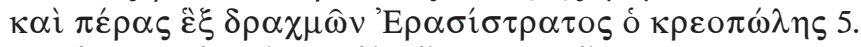

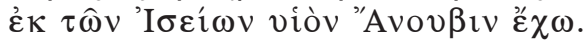

\section{Contra os pintores}

$<$ Pedi-te, Diodoro, que pintasses um belo [quadro do meu] filho,> mas tu apresentas-me um filho alheio,

pondo-lhe ao alto um focinho de cão, de tal modo, que eu até choro,

[ao ver] como o meu Zopírion nasceu de uma Hécuba ${ }^{(519)}$,

e como eu, Erasístrato, o açougueiro, para além das seis dracmas [pagas],

tenho um filho Anúbis ${ }^{(520)}$, [desses] dos templos de Ísis.

\section{3. [LCL, vol. IV, p. 260: Livro XI, no 396.}

\section{[PRESENTE INCOMPLETO]}

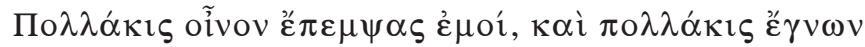

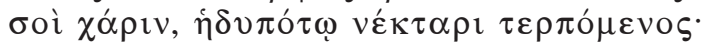

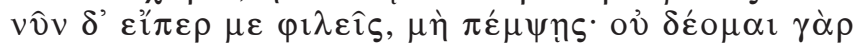

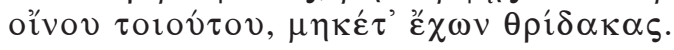

Muitas vezes vinho me mandaste, e muitas vezes eu te agradeci,

${ }^{517}$ Atribuído a Luciano na ed. “Teubner”, e a Lucílio por W. R. Paton.

518 Verso que não consta do ms., mas reconstituído pelos editores modernos.

${ }^{519}$ Hécuba, segunda esposa de Príamo, rei de Tróia, morta pelos Gregos, foi encontrada na forma de uma cadela (há diversas versōes do mito).

${ }^{520}$ Anúbis, deus egóipcio com cabeça de cão (ou de chacal). 
deliciado com esse néctar tão doce de beber.

Mas agora, se és meu amigo, não me mandes mais, pois não preciso

de um tal vinho, uma vez que não tenho alfaces ${ }^{(521)}$.

54. [LCL, vol. IV, p. 260: Livro XI, no 397.

[O RICO... POBRE]

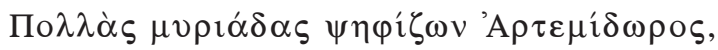

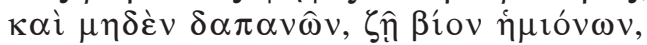

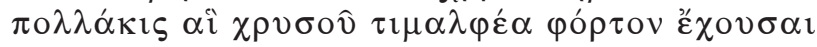

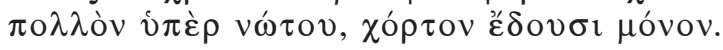

Artemidoro, que conta muitos milhares [de moedas] e não gasta nada, vive uma vida como as mulas, que levam muitas vezes uma preciosa carga de ouro sobre o lombo, mas comem somente palha.

55. [LCL, vol. IV, p. 20: Livro X, no 31 .

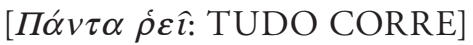

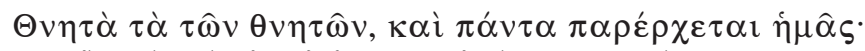

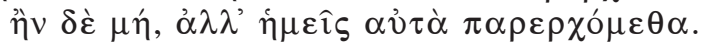

Mortais são as coisas dos mortais, e todas passam por nós, ou melhor, somos nós que passamos por elas.

\footnotetext{
${ }^{521}$ Pelos vistos, a alface era um acompanhamento do vinho...
} 
(Página deixada propositadamente em branco) 


\section{BIBLIOGRAFIA GERAL}

Edições, traduções e comentários

-A. E. Alarcón (1981-1988), Luciano. Obras, I-II, trad., Madrid.

-J. Alsina (1962), Luciano. Obras, ed. bilingue, Barcelona.

-J. Alsina (1981-1988), Luciano. Obras, I-II, trad., Madrid.

-M. T. Amado Rodrigues (2002), Luciano de Samósata. Diálogos dos deuses. Diálogos de prostitutas, Santiago de Compostela.

-J. Bompaire (1993-2003), Lucien. Oeuvres, I-III, ed. bilingue, Paris.

-J. Z. Botella (1987), Diálogos de los Dioses, diálogos de los muertos, diálogos marinos, diálogos de las cortesanas, introd., trad. e notas, Madrid.

-M. C. Dezotti (1996), Luciano. Diálogo dos mortos, ed. bilingue, São Paulo.

-A. M. Harmon, K. Kilburn, M. Macleod (1927-1967), Lucian with an English translation, I-VIII, ed. bilingue, London / Cambridge.

-M. D. MacLeod (1972-1980), Lucian. Opera, I-III, Oxford.

-A. C. Ramalho (1989), Luciano. Diálogo dos mortos, trad., Coimbra.

-B. P. Reardon (1989), A True History, in Collected Ancient Greek Novels, Berkeley / Los Angeles.

\section{Estudos}

-G. Anderson (1976), Studies in Lucian's comic fiction, Leiden.

-G. Anderson (1976), Lucian: theme and variation in the Second Sophistic, Leiden.

-G. Anderson (1982), 'Lucian: a sophist's sophist', YCIS 27: 6192.

-G. Anderson (1996), 'Lucian's Verae Historiae', in G. Schmeling (ed.), The novel in the ancient world, Leiden: 555-562. 
-B. Baldwin (1973), Studies in Lucian, Toronto.

-B. Baldwin (1975), 'The epigrams of Lucian', Phoenix 29. 4: 311-335.

-J. Bompaire (1958), Lucien écrivain. Imitation et création, Paris.

-J. L. Brandão (1995), 'O hipocentauro de Zêuxis: a poética da diferença em Luciano de Samósata’, Humanitas 47. 1: 409424.

-J. L. Brandão (1997), 'A sombra do asno: a filosofia e os filósofos em Luciano de Samósata', Kleos 1. 1: 231-252.

-J. L. Brandão (1998), 'Histoire et fiction chez Lucien de Samosate', Études de Lettres 2: 119-129.

-J. L. Brandão (2001), A poética do hipocentauro. Literatura, sociedade e discurso ficcional em Luciano de Samósata, Belo Horizonte.

-J. L. Brandão (2009), Luciano de Samósata: como se deve escrever a história, Belo Horizonte.

-R. B. Branham (1989), Unruly eloquence: Lucian and the comedy of traditions, Cambridge, Massachusetts.

-M. Fusillo (1999), 'The mirror of the moon. Lucian's A True Story. From satire to utopia', in Oxford readings in the Greek novel, Oxford: 351-381.

-A. Georgiadou, D. Larmour (1998), 'Lucian's Verae Historiae as philosophical parody', Hermes 126. 3: 310-325.

-K. Gilhuly (2007), 'Bronze for gold: subjectivity in Lucien's Dialogues of the courtesans', AJPh 128. 1: 59-94.

-C. P. Jones (1986), Culture and society in Lucian, Cambridge, Massachusetts.

-O. Karavas (2008), 'Lucien de Samosate et la poésie hellénistique', QUCC 88. 1: 109-117.

-K. Korus (1984), 'The theory of humour in Luciano of Samosata', Eos 72. 2: 295-313.

-P. Von Mollendorff (2001), 'Frigid enthusiasts: Luciano n writing history', PCPS 47: 117-140. 
-J. R. Morgan (1985), 'Lucian's True histories and the Wonders beyond Thule of Antonius Diogenes', CQ 35. 2: 475-490.

-H. G. Nesselrath (1998), 'Lucien et le Cynisme', Antiquité Classique 67: 121-135.

-R. Nickel (1999), 'Lucian's True Story: impressions of a fancy voyage', Euphrosyne 27: 249-257.

-J. H. Oliver (1980), 'The actuality of Lucian's Assembly of the gods', AJPh 101. 3: 304-313.

-M. F. Silva (1997), 'No inferno com Luciano. Os caçadores de heranças, uma pecha social', in Actas do II Colóquio Clássico, Aveiro: 25-43. 
(Página deixada propositadamente em branco) 


\section{Volumes publicados na ColecÇáo Autores Gregos e LATINos - SérIe TeXtos GREgos}

1. Delfim F. Leão e Maria do Céu Fialho: Plutarco. Vidas Paralelas - Teseu e Rómulo. Traduçáo do grego, introdução e notas (Coimbra, CECH, 2008).

2. Delfim F. Leão: Plutarco. Obras Morais - O banquete dos Sete Sábios. Tradução do grego, introdução e notas (Coimbra, CECH, 2008).

3. Ana Elias Pinheiro: Xenofonte. Banquete, Apologia de Sócrates. Tradução do grego, introdução e notas (Coimbra, CECH, 2008).

4. Carlos de Jesus, José Luís Brandão, Martinho Soares, Rodolfo Lopes: Plutarco. Obras Morais - No Banquete $I$ - Livros I-IV. Tradução do grego, introdução e notas. Coordenação de José Ribeiro Ferreira (Coimbra, CECH, 2008).

5. Ália Rodrigues, Ana Elias Pinheiro, Ândrea Seiça, Carlos de Jesus, José Ribeiro Ferreira: Plutarco. Obras Morais - No Banquete II - Livros V-IX. Tradução do grego, introdução e notas. Coordenação de José Ribeiro Ferreira (Coimbra, CECH, 2008).

6. Joaquim Pinheiro: Plutarco. Obras Morais - Da Educação das Crianças. Tradução do grego, introdução e notas (Coimbra, CECH, 2008).

7. Ana Elias Pinheiro: Xenofonte. Memoráveis. Tradução do grego, introdução e notas (Coimbra, $\mathrm{CECH}, 2009)$. 
8. Carlos de Jesus: Plutarco. Obras Morais - Diálogo sobre o Amor, Relatos de Amor. Tradução do grego, introdução e notas (Coimbra, CECH, 2009).

9. Ana Maria Guedes Ferreira e Ália Rosa Conceição Rodrigues: Plutarco. Vidas Paralelas - Péricles e Fábio Máximo. Tradução do grego, introdução e notas (Coimbra, CECH, 2010).

10. Paula Barata Dias: Plutarco. Obras Morais - Como Distinguir um Adulador de um Amigo, Como Retirar Benefício dos Inimigos, Acerca do Número Excessivo de Amigos. Tradução do grego, introdução e notas (Coimbra, CECH, 2010).

11. Bernardo Mota: Plutarco. Obras Morais - Sobre a Face Visivel no Orbe da Lua. Tradução do grego, introdução e notas (Coimbra, CECH, 2010).

12. J. A. Segurado e Campos: Licurgo. Oração Contra Leócrates. Tradução do grego, introdução e notas (Coimbra, CECH /CEC, 2010).

13. Carmen Soares e Roosevelt Rocha: Plutarco. Obras Morais - Sobre o Afecto aos Filhos, Sobre a Música. Tradução do grego, introdução e notas (Coimbra, $\mathrm{CECH}, 2010)$.

14. José Luís Lopes Brandão: Plutarco. Vidas de Galba e Otão. Tradução do grego, introdução e notas (Coimbra, CECH, 2010). 
15. Marta Várzeas: Plutarco. Vidas de Demóstenes e Cícero. Tradução do grego, introdução e notas (Coimbra, $\mathrm{CECH}, 2010)$.

16. Maria do Céu Fialho e Nuno Simóes Rodrigues: Plutarco. Vidas de Alcibiades e Coriolano. Tradução do grego, introdução e notas (Coimbra, CECH, 2010).

17. Glória Onelley e Ana Lúcia Curado: Apolodoro. Contra Neera. [Demóstenes] 59. Tradução do grego, introdução e notas (Coimbra, CECH, 2011).

18. Rodolfo Lopes: Platão. Timeu-Crítias. Tradução do grego, introdução e notas (Coimbra, CECH, 2011).

19. Pedro Ribeiro Martins: Pseudo-Xenofonte. A Constituição dos Atenienses. Tradução do grego, introdução, notas e índices (Coimbra, CECH, 2011).

20. Delfim F. Leão e José Luís L. Brandão: Plutarco. Vidas de Sólon e Publícola. Tradução do grego, introdução, notas e índices (Coimbra, CECH, 2012).

21. Custódio Magueijo: Luciano de Samósata I. Tradução do grego, introdução e notas (Coimbra, CECH/IUC, 2012).

22. Custódio Magueijo: Luciano de Samósata II. Tradução do grego, introdução e notas (Coimbra, CECH/IUC, 2012).

23. Custódio Magueijo: Luciano de Samósata III. Tradução do grego, introdução e notas (Coimbra, CECH/IUC, 2012). 
24. Custódio Magueijo: Luciano de Samósata IV. Tradução do grego, introdução e notas (Coimbra, CECH/IUC, 2013).

25. Custódio Magueijo: Luciano de Samósata $V$. Tradução do grego, introdução e notas (Coimbra, CECH/IUC, 2013).

26. Custódio Magueijo: Luciano de Samósata VI. Tradução do grego, introdução e notas (Coimbra, CECH/IUC, 2013).

27. Custódio Magueijo: Luciano de Samósata VII. Tradução do grego, introdução e notas (Coimbra, CECH/IUC, 2013).

28. Custódio Magueijo: Luciano de Samósata VIII. Tradução do grego, introdução e notas (Coimbra, CECH/IUC, 2013).

29. Custódio Magueijo: Luciano de Samósata IX. Tradução do grego, introdução e notas (Coimbra, CECH/IUC, 2013). 
(Página deixada propositadamente em branco) 


\section{OBRA PUBLICADA \\ COM A COORDENAÇÁO \\ CIENTÍFICA}

○
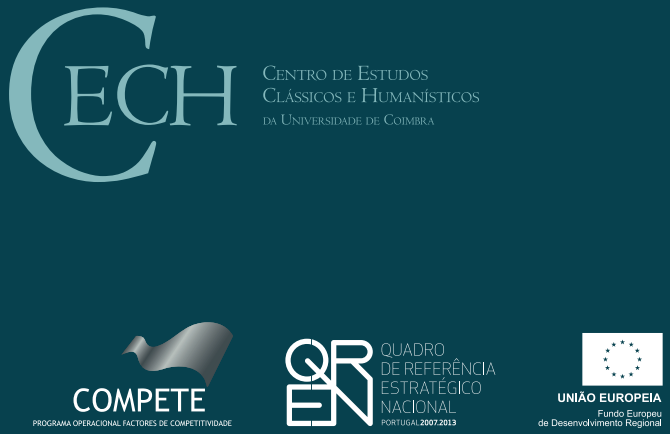